University of South Florida

DIGITAL COMMONS

Digital Commons @ University of

@ UNIVERSITY OF SOUTH FLORIDA

South Florida

Government and International Affairs Faculty

Publications

Government and International Affairs

Spring 5-2013

\title{
The Dialectics of Citizenship: Exploring Privilege, Exclusion, and Racialization
}

\author{
Bernd Reiter \\ University of South Florida, breiter@usf.edu
}

Follow this and additional works at: https://digitalcommons.usf.edu/gia_facpub

Part of the Government Contracts Commons, and the International Relations Commons

\section{Scholar Commons Citation}

Reiter, Bernd, "The Dialectics of Citizenship: Exploring Privilege, Exclusion, and Racialization" (2013). Government and International Affairs Faculty Publications. 1.

https://digitalcommons.usf.edu/gia_facpub/1

This Book is brought to you for free and open access by the Government and International Affairs at Digital Commons @ University of South Florida. It has been accepted for inclusion in Government and International Affairs Faculty Publications by an authorized administrator of Digital Commons @ University of South Florida. For more information, please contact digitalcommons@usf.edu. 
THE DIALECTICS OF CITIZENSHIP 



\title{
THE \\ DIALECTICS OF CITIZENSHIP \\ Exploring Privilege, Exclusion, and Racialization
}

\author{
Bernd Reiter \\ Michigan State University Press \\ East Lansing
}


Copyright (C) 2013 by Bernd Reiter

( The paper used in this publication meets the minimum requirements of ANSI/NISO Z39.48-1992 (R 1997) (Permanence of Paper).

Michigan State University Press

East Lansing, Michigan 48823-5245

Printed and bound in the United States of America.

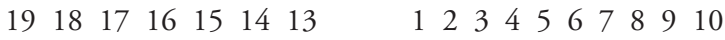

LIBRARY OF CONGRESS CATALOGING-IN-PUBLICATION DATA

Reiter, Bernd, 1968-

The dialectics of citizenship: exploring privilege, exclusion, and racialization / Bernd Reiter. p. $\mathrm{cm}$.

Includes bibliographical references and index.

ISBN 978-1-61186-065-8 (pbk.: alk. paper)—ISBN 978-1-60917-351-7 (ebk.)

1. Citizenship. 2. Autonomy. I. Title.

JF801.R43 2013

$323.601-\mathrm{dc} 23$

2012029285

Book design by Scribe Inc. (www.scribenet.com)

Cover design by Erin Kirk New

Cover photograph of the US/Mexican border fence (C) Jürgen Escher/laif/Redux and is used by permission of the photographer, all rights reserved. For more of Jürgen Escher's work please visit www.juergenescher.de. All rights reserved.

F green Michigan State University Press is a member of the Green Press Initiative and

INITIATIVE is committed to developing and encouraging ecologically responsible publishing practices. For more information about the Green Press Initiative and the use of recycled paper in book publishing, please visit www.greenpressinitiative.org. 
Intelligent fools, PhD's in illusion, Masters of mass confusion, Bachelors in past illusion, Now who you choosin' —LAURYN HILL, "FREEDOM TIME" 



\section{Contents}

Prologue $\quad$ ix

Introduction $\quad$ xi

Chapter 1. The Epistemology and Methodology of Exploratory Social Science Research: Crossing Popper with Marcuse

Chapter 2. Conceptualizing Citizenship: Disjunctive, Dual, Divided, Entangled, or What?

Chapter 3. Classical Citizenship: The Political and the Social

Chapter 4. Medieval European Citizenship: Christian Rights and Jewish Duties

Chapter 5. France: Liberalism Unveiled

Chapter 6. The Postcolonial Within: Portugal, White and European

Chapter 7. Brazil: Experts in Exclusion

Chapter 8. Colombia: When Law and Reality Clash

Chapter 9. Conclusion: Learning from Exploratory Research

Notes

References

Index 



\section{Prologue}

THIS BOOK GROWS OUT OF, AND INDEED CONNECTS TO, PREVIOUS efforts (Reiter 2009; Nef and Reiter 2009). Its realization would have been impossible without the support I have received from the Desigualdades Network of the Free University of Berlin. I am very grateful for the support they have given me and want to express my sincere thanks, especially to Prof. Sergio Costa. My time in Berlin and the dialogues I had with fellows, students, postdocs, and faculty have proven invaluable and allowed me to push my thoughts forward in significant ways. I am also indebted and very grateful for the critical and constructive comments I have received on earlier versions of several chapters of this book from Manuela Boatcă, Mitchell Glodek, Ulrich Oslender, Sergio Costa, Katherine Lebow, and Eric Wolters. Finally, I want to thank my home institution, USF, especially my director, Rachel May, and my chair, Mohsen Milani, for allotting me the time and freedom necessary to finish this book. Thanks! 



\section{Introduction}

Philosophers have only interpreted the world in
various ways: the point is to change it.

-KARL MARX, 1845

The Central theme of this book is aUtonomy and Self-RULe. IT focuses on those sites, historical and geographical, where people have taken up the banner of self-rule and established democratic systems. As soon as they have done so- and this is the thread weaving together the different stories here told - they had to face the adversary of those who had something to lose, namely, their own power and their privileges. At the same time that this book tells the story of autonomy and self-rule, it also tells the story of the defense of privilege, of exclusion and second-class citizenship, because one story cannot adequately be told without the other.

Democracy, understood here in the strong sense, that is, as the strife to rule oneself and achieve autonomy, never "came about" - it was always fought for. In the same way, it never "vanished" or "withered away"; it was taken away, dismantled, or weakened by those who had something to lose from self-rule. The ways to establish democracy were as cunning as the ways to weaken and destroy it-and this book takes a closer look at how exactly this epic struggle played out, and still plays out, in different parts of the world. It focuses on the efforts of specific groups to establish self-rule and democracy, and it analyzes how their efforts were met by those I call "the included," that is, the privileged who tend to benefit from the exclusion of others (Nef and Reiter 2009).

It is important to highlight that this book grows out of praxis-my own praxis as someone working for and thus concerned with democracy, self-determination, power, democracy, and autonomy — both my own and those of others. Starting from praxis, I contend, makes all the difference. What follows is done in an effort to think through-and offer tools to 
analyze - some of the most central problems and questions of my life and, I would think, the lives of many others. How to be free? How to achieve more justice and autonomy? How to recognize the maneuvers of the privileged to undo the efforts of the excluded to attain these goals? Hence also: How to improve the democracies we live in? Behind all these questions stands the will to address shortcomings and offer tools for improvement. This is at the same time easier and harder than it seems. It is easy because to achieve such practical goals, we do not need most of the extremely complicated, cryptic, and lofty theories offered by some of the "recognized thinkers" of our day. Most problems we have are not that complicated, after all, and it rather seems that some of "our" thinkers and writers artificially complicate issues in order to mystify them, instead of elucidating them. Some also seem more motivated to add to their own prestige (and positions/salaries) than to offer usable tools to all those who could actually benefit from such analyses. Most of academic life has become a sort of vanity fair of exalted egos whose central aim seems to be to flatter themselves by inventing ever-more sophisticated proposals and languages (attend a random academic conference to verify). It might indeed even be, as Cornelius Castoriadis thought, that "we live in a period of appalling ideological regression among the literati" (Castoriadis 2001: 24). This trend also complicates this book, because it forces me to navigate through, and combine wherever possible, different languages in an act to translate the useful, decipher the cryptic, highlight the helpful, and in the midst of all of this, explain my own thinking.

Luckily, I have found in the work of Greek philosopher Cornelius Castoriadis (1922-1997) a strong ally in this endeavor. His work on autonomy has allowed me to sharpen my gaze and, if you will, "keep the eye on the prize." I share Castoriadis's starting position and focus on autonomy, and his definition of autonomy sets the tone for my efforts as well:

But what does "autonomy" signify? Autos: oneself; nomos: law. The person who gives herself her own laws is autonomous. (Not, The person who does whatever comes into her head, but rather, The person who gives herself laws.) Now, that is immensely difficult. For an individual, to give oneself one's own law, within the fields in which this is possible, requires the ability to hold one's own in the face of all conventions, beliefs, fashion, learned people who maintain absurd ideas, the media, the silence of the public, and so forth. And for a society, to give itself its own law means to accept at bottom the idea that it is creating its own institution, and that it creates that institution without being able to invoke any extrasocial foundation, any norm of norms, any measure of its measures. This therefore boils down to saying that such a society should itself decide what is 
just and unjust - and this is the question with which true politics deals (we are obviously not talking here about the politics of the politicians who occupy the stage today) (Castoriadis 1985: 158).

However, even if I follow Castoriadis in many of his analyses and critiques and share his preoccupation with autonomy and self-rule, I do not share his assessment of the Greco-Roman-Western path as a unique one. Even though it does seem that this path has thoroughly colonized the world (Chakrabarty 2000), I simply do not know enough about the world in order to make, or support, such a statement. Making this sort of argument is not my aim here. This book, too, focuses on democratic Athens as the place where self-rule was first documented, but this focus is due to the availability of sources and does not imply that similar experiments were not undertaken elsewhere. It then focuses on other contested historical sites of struggle for self-rule, namely the Roman Republic, medieval Italian city-states, and postrevolutionary France. The struggle for autonomy and self-rule is, however, not historical-it continues to be fought today, as the struggles in Egypt, Syria, Yemen, Morocco, Palestine, fought while I am writing this book, amply testify. To capture the different struggles for self-rule and to analyze the ways in which, and why, these efforts are blocked and contained by elites and their allies, I have included four contemporary cases, namely, France, Portugal, Colombia, and Brazil.

Those cases are selected because they are particularly telling and thus allow us to gain exceptionally deep insights into the dynamics of this struggle for self-rule. Chapter 1 will elaborate further on the methodology applied here, which is one of exploration. Here, it is important to highlight that all those marching, and willing to die, for democracy in the past and today do so not to establish a system where one sort of ruler is substituted for another, even if elected. "Elite democracy," as it has been called, is not what the idea of democracy promises. It promises self-rule (Mansbridge 1980). Similarly, at the heart of the disappointment many experience worldwide with their own established democracies lies a lack of self-rule, which means a lack of active citizenship. Passive citizenship, second-class citizenship, or exclusion from citizenship altogether while being an effective resident in a democratic country, all contribute to alienation from politics, from government, from the state, and even, as I shall show, from "the political" itself, so that whole generations of people living in established democracies seem disinterested in it. ${ }^{1}$ Why should they be interested in it if nothing seems at stake for them? The leaders they elect do nothing to allow self-identification with them and their issues (and if they do, it never seems genuine). Self-rule 
cannot be delegated. According to Castoriadis, "The project of autonomy itself is certainly not finished. But its trajectory during the last two centuries has proved the radical inadequacy, to say the least, of the programmes in which it had been embodied-be it the liberal republic or Marxist-Leninist 'socialism.' That the demonstration of this inadequacy in actual historical fact is one of the roots of present political apathy and privatization hardly needs stressing. For the resurgence of the project of autonomy, new political objectives and new human attitudes are required" (Castoriadis 2001: 26). I agree. The current (2011-2012) political events filling our newspapers, from the Arab Spring to the Tea Party, all suggest a profound discontent with the ways "democracy" has come to be understood and practiced. The minimal common denominator seems to be that many citizens have lost their trust in the political system, perceiving that politicians do not truly represent us and/or that they do not represent us truthfully. Rather, they act as elites, in their own interests, or in the interests of the most powerful stakeholders-in most cases big corporations. As representation is in crisis, the whole democratic system evokes discontent and mistrust. In short: the practice of citizenship needs rethinking and reorientation.

The most prevalent strategy to uphold elitism has been to shift the core discussions rightfully pertaining to self-rule out of the political realm into the administrative or legal realms, and to transform citizenship from a political practice to a set of legal rights and administrative rules. Citizenship has been thoroughly legalized and "commodified," in the words of John Pocock (1995) — that is, transformed from a political practice into a legal concept without many teeth. At the same time, in almost all contemporary democracies, democracy came to mean elite rule, exercised and upheld through representation. Self-rule, the original idea behind democracy, was practiced in but a few places, for relatively short periods of time, and it was always opposed vehemently because of its radicalism. And radical it is, as the idea of ruling oneself does not go with many of the things we have come to accept as fitting under the label "democracy." Such ideas as democratic representation and citizenship as a legal status clearly are at odds with what Athenian citizens, the burghers of Pisa and Lucca, and the French revolutionaries wanted. They are also at odds with what the citizens of Egypt want today, as well as with what the excluded and second-class citizens of Portugal, Colombia, and Brazil want and expect from their already established democratic systems. They all want a voice and an active say in the molding of their lives. They want self-rule, autonomy, and justice-not a system of elected and corrupt, or corrupted, elites. In other words, they want true citizenship. But what is true citizenship? What does it look like? 
How has it been achieved, and what can we learn from where it has failed? With these questions, the focus of this book is defined. I set out to analyze the struggles for autonomy and self-rule, and to dissect the opposing forces and strategies that block its advancement.

I have found the most fruitful way to achieve this by focusing on the relationships that link citizenship to exclusion, and on the struggles and processes that constitute the field in between citizenship and exclusionthat is, the struggles of those who seek self-rule, autonomy, justice, and democracy, and those who oppose them for the sake of defending their own privileges. In other words, I have found it helpful to think of the relationship between inclusion and exclusion in and from citizenship as one that is dialectical, where one constitutes and conditions the other. This argument at once constitutes the unit of analysis of this entire book-namely, the space, or maybe the field of tension, that emerges between the two poles of citizenship and exclusion. ${ }^{2}$ This focus also gives the book its title.

To demonstrate the fruitfulness of this analysis, the empirical analysis presented here starts where citizenship itself started-at least where we think and know it started, namely, in classical Athens. From there, I shall follow the development and expansion of citizenship and democracy and thus analyze the Roman Republic, medieval city republics, and postrevolutionary France. All these are obvious places to look in this genealogy of citizenship, even though they are certainly not the only ones, and I do not want to claim that the European experience is superior to another. To the contrary, this book adds to the effort to "provincialize Europe" (Chakrabarty 2000) by offering a critical analysis of what has been called the "Western democratic tradition" and showing its inherent limitations and contradictions. To fully achieve this, this book also includes a discussion of three contemporary cases, namely, Portugal, Brazil, and Colombia.

It is at this point important to explain that my aim in this book is to offer an approach that contributes to unveiling the common thread that brings all the cases discussed here together, namely, the dynamics that produce different forms of exclusion and block the achievement of more autonomy, self-rule, and hence genuine democracy. I should also explain that even though my aim is practical, the work presented here is firmly rooted in the social sciences, offering theory-driven explanations of social reality. Thus, even though I present and use historical information, this work aims not at contributing to the production of historical knowledge. In fact, none of the historical evidence presented here is new, and it is taken almost entirely from already published work. I am not aiming to present new facts, but new explanations about facts and thus new, fruitful, and innovative ways to 
look at facts and reality. This is, I want to argue, all that honest social science can and thus should do. In my mind, any heuristic claims beyond are ill-begotten and misleading and ultimately responsible for the lack of systematic knowledge production in the social sciences. Given that this claim is controversial, I have dedicated some space to elaborating it. Chapter 1 discusses these issues in some detail, and by doing so it lays out the epistemological and methodological foundations for this book. However, chapter 1 is relevant beyond the cases of this book. It stands on its own and can be read separately and taken as a general discussion on the epistemology, theory, and methodology of the social sciences. It is of especial interest to all those interested in qualitative, explorative research, as I seek to provide a rationale for explorative research in general.

Citizenship — or better, the reality represented by it—can be analyzed in many different ways. This book sets out to focus on its inherent tensions and contradictions, and on the ways different people and groups have sought to uphold and defend their citizens' rights against others. By doing this, a sort of genealogy of exclusion and second-class citizenship slowly emerges as the books moves from one empirical case to the next. The analytical framework chosen makes it appear as if citizenship was never only about status and belonging to a specially delimited community, as T. H. Marshall (1950) has argued, but always also about setting oneself apart from others and thus defining and constituting one's rights in contrast to others' non-rights and duties. I deliberately chose to say "this framework makes it appear this way" because, as I shall seek to demonstrate in chapters 1 and 2 , the theoretical framework applied to an empirical reality will influence and distort what we see-even make us blind to some aspects of that same reality that we would otherwise see had we chosen a different theoretical framework (Whorf and Carroll 1964; Davidson 1974; Lakoff 2009). This, of course, leaves us in a predicament if we aim at explaining "the" reality, or "all" reality. I shall avoid this claim and instead explain "a" reality, one that I find important to also consider when reading the important and influential work of such authors as T. H. Marshall (1950), Margaret Somers (1993), Ensing Isin (2000, 2008), Ayelet Shachar (2009), Joseph Tulchin and Meg Ruthenberg (2007), and many others - all of whom have done much to explain what citizenship is and how it was experienced by different peoples at different times.

The reality I want to further elucidate here is one hiding behind the legal category of citizenship. I am interested in exploring how citizenship is lived, experienced, imagined, and performed in people's everyday lives, and how these performances reflect back on the identities of those having to 
negotiate, defend, and uphold their status of rightfully belonging, as well as how they impact, influence, and qualify the democratic regimes that have citizenship as their cornerstones. This choice restricts the domain of this book to democracies and citizens, and thus excludes non-democracies and noncitizens from the realm dealt with here.

Furthermore, this kind of approach is akin to the one applied by Benedict Anderson (2006), who takes nationalism as an "anthropological category" (Anderson 2006: 6) and is thus able to analyze how nationalism is enacted and experienced. Similarly, I seek to explore what it means to be a citizen, and how different people and groups flesh out its meaning in their mutual and daily interactions, as well as their interactions with governments and states, thus investing it with concreteness. As stated above, the most fruitful way to achieve this is by focusing on the field of tension created by citizenship's inherent contradictions and its relationship to exclusion.

Hence, this book aims to contribute. It aims to add to our understanding of what citizenship means and has meant, and it aims to add to the knowledge that other scholars have already produced in this field. It does not aim to substitute for or replace that knowledge. Social science, conducted honestly, as I shall argue in chapter 1, should steer away from such totalitarian claims and position itself in a more humble fashion, because as social scientists, we seek to explain an ever-changing reality that is constantly explained and categorized by different actors who do not share the same angle or approach to reality, thus producing different, divergent, and even contradictory readings and understandings, all of which have a tendency to become reified and even institutionalized (Brubaker 2004; Berger and Luckmann 1966). This tendency complicates the production of reliable knowledge about social reality tremendously, as all social facts are indeed laden with meaning, thus escaping an unmediated and simple, or straightforward, comprehension. In other words, social reality is composed of material things that are woven into linguistic and symbolic acts from which they cannot be pulled apart, because they indeed only become reality through this interwovenness. What some social scientists call "realism" is indeed a sort of epistemological and ontological naiveté about the stuff that reality is made of.

Humility, however, is not a highly valued currency in the academic marketplace, so that most social-science treatises we know claim far too much and do not recognize the limits that scientific methodology automatically imposes on research practitioners. Scientific procedure, while able to assure more reliable knowledge than the one produced without a clear methodology, 
automatically cuts away all those knowledges that do not fit into a methodological apparatus. The great majority of the "things we know" are thus lost to us. As scientists, we end up instead with only what we can prove and demonstrate-which has been very little indeed. Practicing social science is nevertheless worth our while if done honestly, with transparency, humility, insight, and self-awareness - and when aimed at the very real and serious problems of our times. The quest for self-rule, autonomy, citizenship, and democracy certainly qualifies, and although it is promising, it continues to pose one of the most serious challenges to our collective well-being. We cannot afford to leave its discussion to power-seeking demagogues, self-interested business elites and corporations, or a media invested only in entertaining us while selling us things we do not need.

Hence, what this book seeks to accomplish is a different, and hopefully insightful, way to think about citizenship and to make scientifically reliable and valid inquiries into the reality represented by this concept. If successful, it should unveil new facets of citizenship hitherto left unexplored, and it should inspire others to conduct similar inquiries, providing them with some methodological guidelines and worthwhile questions to ask. I hope that the effort I have put into this book also inspires people outside the academic world, giving them new ideas and proposals with which to think about democracy, autonomy, and self-rule, and to use when deciding which actions to take.

\section{CHAPTER OVERVIEW}

Chapter 1 lays the groundwork for the book by discussing the epistemological and methodological issues and pitfalls involved in social-science research. ${ }^{3}$ It is particularly focused on problems of reification-that is, the unplanned feedback and interference created when social-science or census categories reflect back on the social world and are used to form identities. By insisting on a clear separation between words, models, and reality, the chapter lays out the foundations of exploratory, inductive social-science research.

Chapter 2 focuses on the concept of citizenship and proposes a way to fruitfully analyze the social reality represented by this concept-keeping in mind the caveats discussed in the previous chapter. This chapter proposes to think of citizenship in terms of a positional good, as well as a social role. Such a conceptualization provides innovative analytical tools that allow for an analysis of some of the previously unexplored aspects of citizenship, 
especially its inherently exclusionary character. To further capture the intrinsically contradictory nature of citizenship, this chapter elaborates a "dialectics of citizenship"-both to provide an analytical approach, and to adequately describe the phenomenon of citizenship.

Chapter 3 focuses on classical citizenship as it was practiced in democratic Athens and republican Rome. First, the chapter focuses on the very sense of what it meant to be a citizen in Athens, concluding that the main trait was that in Athens, there was no clear separation between rulers and ruled, thus making alienation from politics, or the state, impossible. Instead, Athenian citizenship demanded many duties alongside the rights it offered. Athenian citizenship was foremost political membership-a character it soon lost, as the analysis of the Roman Republic demonstrates. There, citizenship was codified into a set of rights, perceived as entitlements, and access to these rights was conditional on one's social and economic standing. Rome is also the beginning of representation, another tradition we have kept alive since then.

Furthermore, this chapter also discusses the ways in which Athenian politicians and reformers such as Solon, Cleisthenes, and Ephialtes have sought to remedy and counteract the very prevalent social and economic inequalities that divided the people of Attica at the time. Instead of trying to change social or economic realities, as was done ever after, they sought to devise political institutions that forced different people and groups together into one political association, while at the same time splitting up otherwise powerful clans that threatened to bring imbalance into the system. In doing so, these reformers provided an example of what democratic politics should aim for and how to best achieve it-raising important questions about the proper separation of the social from the political. This chapter also discusses the many exclusions of classic democracy, especially in Athens.

Chapter 4 seeks to fill the historical gap between classic democracy and citizenship and contemporary manifestations, originating in the French Revolution. In the almost 1,800 years in between those democratic experiments, much happened that this chapter cannot possibly account for. This chapter thus is the place to highlight the limits of such a study as the one presented here, as there are not enough sources to discuss citizenship in other, non-European regions. Even the knowledge we have about the 1,800 years covered in this chapter is scant, thus forcing the analyst to once more focus on those cases where sources exist. Given that the intent of this study is to critique the Western democratic tradition and to deconstruct some of its central tenets, I hope that this Eurocentric focus will not be held against me. In order to reduce all the possible ways in which to discuss such a huge 
span of time, this chapter focuses on the situation of the Jews in Europe, because they provide a crucial case for the study of European democracy. Doing so, the chapter detects a pattern, namely, that Christian advance was routinely achieved by climbing on the backs of the perpetual "others" in Europe, the Jews. This history is reconstructed all the way from the forceful baptism of all Jews ordered by the Frankish king Chilperic in 582, to the granting of civil rights to Jews in Prussia (1886).

Furthermore, this chapter explores one of the few better-documented examples of medieval citizenship, namely, the one practiced in the medieval Tuscan republics of Florence, Pisa, Siena, Lucca, Genoa, among others, between the tenth and the fifteenth centuries. The focus in this analysis is also on the limits and contradictions of citizenship-even though not too much historical material exists to gain a detailed picture. Citizenship then, it becomes clear, meant just as much as it did in Athens and was as exclusionary, thus confirming the general theme that the more citizenship meant, the more exclusive it was held to be.

Chapter 5 then shifts to the birthplace of modern citizenship, France. This chapter is divided into two parts. First, it discusses the limits of the liberal discourse that emerged during the French Revolution when black former slaves in the French colonies sought to apply these discourses to their own situation. Liberalism quickly found its limits in this situation, to the point where all those who stood up for black rights found a quick, and often painful, death at the hands of those whose economic interests were threatened by such ideas. However, once slavery was ended, the problems for free blacks continued-a phenomenon nicely captured by the title of Thomas Holt's (1992) book The Problem of Freedom, as historically privileged whites now had to devise new mechanisms to defend their undeserved privileges.

This pattern of defending white privilege, a privilege first established during colonization, is also what makes the bridge to contemporary France, where nonwhite French citizens face serious and systematic discrimination, especially in the job market. The white majority, which elects its representatives, has devised many ways to defend these privileges against nonwhites-which is the theme of the remainder of chapter 5 .

Chapter 6 shifts our attention to Portugal, one of the richest and most interesting cases for any study of European citizenship-yet at the same time one of the least studied. What makes Portugal such a rich case for exploratory research is its long colonial history and the "colonial entanglements" it created during this time. As a result of prolonged colonialism, Portugal first defined its national community as one that included Africans-only to later reverse this action and define it without Africans. Such maneuvering 
was triggered by the need to justify still having colonies during the $1960 \mathrm{~s}$ and 1970s — hence the argument that "those were not colonies, but part of the Portuguese nation" - and later, after applying for EU membership, the need to demonstrate that Portugal was not inviting Africa into the EU, or even that Portugal was not an African-European nation itself at the time of joining the EU in 1986. There are but few cases where such strategic maneuverings can be observed with such clarity as in Portugal. Not only does Portugal allow for a study of the tensions that arise when national community and civil unity do not overlap; it also provides fertile ground for a study of what happened to different people and groups in the middle of these state-led changes. How to get rid of the "African connection" that so implicated Portugal thus became a major effort of state elites, as did how to define the African-descendant citizens of Portugal as not really belonging to the nation. This was achieved, as this chapter shows, with much help from different state and societal elites-including those working as scholars in Portugal's public universities. This chapter thus shows, as the title implies, how the Portuguese states made foreigners out of black citizens.

Chapter 7 then finally shifts the focus of the book away from Europe, and first to Brazil. Brazilians, so the chapter argues, are "specialists in exclusion." Given this country's long colonial history and its vast contingent of black and indigenous people, white Brazilians, who saw and to some extent still see themselves as the true inheritors of the country as it was handed down to them by the Portuguese colonizers, had to be especially inventive when it came to securing their own privileges-especially after democratization in 1985. And creative they were-making Brazil a very rich and telling explorative case for anybody interested in how exclusion works. The focus of this chapter has taken me away from the confinements of my own discipline, political science, and it made me delve into linguistics and the use of formalism and procedural protocols in order to shield those who seek inclusion and participation from gaining access and voice. In a country where access to formal education is still a privilege of relatively few, the historically included have resorted to the use of extremely formal and erudite language codes-in their speech, but even more consequentially in written Brazilian-Portuguese language. By engaging in such elevated language games, included Brazilians are able to hold the historically excluded out, or to silence them if they manage to penetrate such protected societal spheres where money and power circulate and are negotiated daily. The theme of this chapter is "the formal against the informal," as it zeroes in on the different strategies used by the formal sectors of society to uphold and defend their historical privileges. 
The final empirical chapter of this book is about contemporary Colombia. In 1991, the Colombian state gave itself a new constitution, for the first time ever recognizing ethnic minorities and investing them with a set of very specific rights. Law 70, passed in 1993, further specifies some of the general provisions anchored in the 1991 constitution by making specific references to the country's black communities. Colombia thus serves as an exemplary case for all the other Latin American countries that have passed similar constitutions over the past fifteen years. However, despite all the new laws and constitutions, the situation of minorities continues to be dire. The central research question driving this chapter is how such a great gap between law and reality, especially the reality of Afro-Colombians, can be explained. To address this question, this chapter explores some of the pitfalls that are inherent in the tradition of legal idealism that normally comes with the code law tradition. Laws are written without keeping reality in mind, thus presenting not a reality, but rather a fantasy of those able to participate in the formulation of such codes-elites. The Colombian case is slightly different in this respect, because it was not elites, but a popularly elected constituent assembly-a constituyente- that wrote the constitutional text. The Colombian case demonstrates how important it is to disaggregate the state when analyzing state action. It becomes clear that the legislative and executive branches of the Colombian government are under firm elite control. The judiciary, to the contrary, has been able to secure a limited measure of independence-even if constantly threatened. The result is that laws that are passed are then violated by those agencies working for the executive branch, or representing the interests of those populating the legislative branch. Furthermore, Colombia provides a prime example of the force of racism in a country that is officially colorblind. Because racism is so hard to pin down, its influence is not diminished. To the contrary, racist practices are more difficult to expose and to counteract, so that lawsuits against racist incidents are minimal in Colombia. This phenomenon of not taking anybody to court is also another crucial characteristic, not just of Colombia, but of other Latin American countries as well, including Brazil. Given that here, as everywhere, citizenship has long been commodified and defined as a set of legal entitlements-or, as Pocock has argued, "the right to sue and be sued"-such a limited and highly circumscribed access to the court system provides a formidable block to gaining access to the full range of what citizenship can and should mean.

Chapter 9 provides a conclusion in that it seeks to summarize and weave together the different threads this book has laid out during the different empirical, theoretical, and methodological chapters. In it, I also seek to draw some conclusions of a more general character-for example, about the 
place of exploratory research. The book ends with a note about the importance of dialectical thinking and dialectical research designs that do not sacrifice knowledge for elegance or parsimony, but embrace contradictions and focus on these first and foremost, as they provide the deepest insights into the fabric of social life. 



\section{CHAPTER 1}

\section{The Epistemology and Methodology of Exploratory Social Science Research}

\section{Crossing Popper with Marcuse}

If you insist on strict proof (or strict disproof) in the empirical sciences, you will never benefit from experience, and never learn

from it how wrong you are.

-KARL POPPER, THE LOGIC OF SCIENTIFIC INQUIRY, 2002

THIS CHAPTER SEEKS TO PROPOSE A RATIONALE FOR EXPLORATORY research in the social sciences. Inspired by the recent debates around qualitative methods (Gerring 2001; George and Bennett 2005; Brady and Collier 2004; Mahoney and Rueschemeyer 2003; Ragin 2008, to name just a few), I seek to demonstrate that exploratory research also has a rightful place within the social sciences. In order to live up to its potential, exploratory research needs to be conducted in a transparent, honest, and self-reflexive way — and follow a set of guidelines that ensure its reliability. Exploratory research, if conducted in such a way, can achieve great validity, and it can provide new and innovative ways to analyze reality.

In most cases, exploration demands more from the researcher than confirmatory research, both in terms of preparation and in terms of willingness and ability to expose oneself to foreign cultures and languages, as well as the courage to engage in a critical and honest self-reflection and critique. It also requires intellectual engagement with the topic at stake, far beyond 
the needs of those running regressions from their office computers. However, exploratory research normally demands less money to conduct, as most projects can be done by one researcher alone, without the need to mobilize, train, and pay large research apparatuses. Given the disciplinary power of elite scholars and academic institutions when it comes to selecting research through funding and hiring, exploratory research thus has great emancipatory potential, because it can escape the disciplinary power often exercised by senior "peers" and mainstream funding agencies.

To legitimize and provide a solid epistemological groundwork for exploratory research in the social sciences, it needs to be grounded in a philosophy of science, it has to be articulated within an epistemological framework, and it has to formulate a comprehensive methodological framework that justifies its methods. Thought also needs to be given to the ontology of the social sciences, as decisions about what counts as real and what we shall accept as fact necessarily impact our strategy of inquiry.

\section{THE LIMITS OF CONFIRMATORY SOCIAL SCIENCE}

Confirmatory social science dominates the field. Most social scientists use quantitative or qualitative methods in order to prove, or corroborate, their hypotheses. They expect to confirm laws, regularities, or conditionalities of the if . . then ... sort. Confirmatory research is what graduate students train for and what qualifies most researchers to get a tenure-track academic job. Confirmatory research has indeed many advantages — some of which are also very relevant for exploratory research. Confirmatory research allows for a clear formulation of a theory to be tested in its application, commonly formulated as hypotheses; it allows for bringing order into the research process by formulating theories and related hypotheses up front, and developing a research design and methodological tools best suited to address the research question, which is also formulated up front. By formulating research questions, theories, hypotheses, a research design, and a method—and by forcing the researcher to operationalize the involved terms and concepts and think of indicators to assess them-confirmatory research provides a clear scheme that is easy to follow and hence easy to teach. If trained appropriately in confirmatory research techniques, researchers know how to proceed.

By providing schematic and standardized procedures, confirmatory research also provides a mental map for how inquiry works and what it can achieve. Taking inspiration from the work of Karl Popper (2002) and 
Carl Hempel (1966), confirmatory research proceeds deductively by testing hypotheses. The great advantage of proceeding in such a way lies in the clear and well-structured research process that such an approach is able to secure. Mental models, ideas, or theories are compared to empirical reality and tested for their explanatory power. This allows for an isolation of an empirical domain and a focusing on one clearly delimited facet of reality. It also allows for a zeroing in on one, or a small number of potentially causal relationships and mechanisms. This is absolutely necessary for conducting any sort of empirical research, given the high complexity of reality. In reality, everything potentially relates to everything else-and without a clear theory and hypotheses, we would not be able to isolate specific causal relationships in order to analyze their strength and robustness. Theory and hypotheses allow us to simplify, isolate, and focus on particular aspects of a reality that, taken as a whole, is far too complex and contingent to be captured and explained with any degree of precision and reliability. Confirmatory research thus brings guidance and discipline into an endeavor that would otherwise be impossible and at risk of falling prey to the same kind of contingency that characterizes empirical reality.

Confirmatory research, more pragmatically, also is what society and policymakers expect social scientists to achieve, as in the end, scientists are expected to explain social reality and make predictions that help guide actions and policymaking. One normally does not get paid to speculate. With so many advantages, it comes as no surprise that confirmatory research is the only research that receives external funding and the only research taught systematically at universities, American or otherwise. But what are its weaknesses and shortcomings? Several have been identified.

When testing hypotheses, we normally are not pressed to justify where these hypotheses came from. Popper argues that asking this question is falling prey to "psychologism." After all, we need to concern ourselves not with where ideas come from, but how to assess them systematically. This, however, has led to a systematic neglect of capturing, and considering, the bias that goes into theory and hypothesis formulation. But, as such feminist scholars as Sandra Harding (1991) and Donna Haraway (1988) have convincingly argued, research cannot start from nowhere. Who we are, our interests, backgrounds, training, and culture-influence what questions we ask, how we ask them, and even what we accept as confirming evidence. Our approach to knowledge is "situated," and the worst thing to do is to pretend that it is not, thus playing the "God trick" (Haraway 1988). Thinking about, and critically analyzing, where our theories and hypotheses come from must be included in the research process, else we cannot escape unreflected bias. The 
need to also analyze where our ideas, theories, hypotheses, approaches, and questions come from, and how this pedigree influences our research and our conclusions, cannot be achieved with confirmatory research. This aspect of research needs to be inductive and constructivist - and it triggers the need for an altogether different approach to conducting empirical research in the social sciences.

As if this impossibility of scientifically accounting for one's location and situatedness were not enough, confirmatory research has another weakness. As Popper has made very clear, theories cannot be proved. He shows that "theories are not verifiable, but they can be corroborated" (Popper 2002: 248). Popper concludes his examination of the Logic of Scientific Discovery by stating that "The old scientific ideal of episteme-of absolutely certain, demonstrable knowledge- - has proved to be an idol. The demand for scientific objectivity makes it inevitable that every scientific statement must remain tentative for ever" (Popper 2002: 280). In other words, there is no way to bridge the gap that forever separates the models we formulate in our minds from empirical reality. All our theories, models, and explanations about reality will remain forever tentative, because they spring out of our own minds, and nothing can guarantee that reality conforms to our ideas. We can find laws-but nature, let alone human behavior, might not follow any laws. We might detect causal mechanisms, but we have no guarantee that history unfolds according to linear causes. Independent variables are mind constructs and not independent in reality. Dependent variables are in reality dependent on much more than the independent variables we choose to examine. All we can do-and as a consequence, all that confirmatory researchers do-is to develop highly reliable procedures and machines to process the data we feed into them. However, as reliable as our procedures have become, they are still only able to test our own ideas, theories, and hypotheses. When conducting confirmatory research, we mobilize great resources to test the fruits of our own minds-not reality.

The more precise and mathematical these methods and apparatuses, the more "scientific" they are deemed. By factoring out the human component from the research process, this research seeks to control for bias- but it fails to take into account the human impact that informs any research at the very beginning of the research process, as well as the human condition of the very phenomena it seeks to explain. Conducting contemporary confirmatory research, especially in the social sciences, is like tapping in the dark with a high-tech laser beam instead of the old-fashioned broomstick. It still leaves us clueless about what is in the room and how our own movements rearrange the objects we touch and influence our findings. 
Hence, Sir Karl Popper has put a heavy burden onto the shoulders of confirmatory researchers and challenged their work on the most basic and substantial level. The truth of his assessment becomes evident when analyzing the history of our fields and critically evaluating our achievements. Confirmatory research has indeed confirmed very little. It spends most of its energy in developing and explaining new methods, computer programs, and other machines designed to ensure reliability-but the resulting reliability only applies to the methods, programs, and the machines themselves, never to the findings. Confirmatory research has become highly efficient in attesting the reliability of its own methods, but utterly unable to address the basic problems of reality.

If hard truths about reality, especially about social (that is, human) reality, are altogether out of our reach, then what can and should science, and social science in particular, do? Exploratory research offers some attractive alternatives. They rest on an explicit recognition that all inquiry is tentative; that reality is, in part, socially constructed; that researchers are part of the reality they analyze; and that the words and categories we use to explain reality grow out of our own minds and not out of reality. In other words, what we perceive and how we perceive it has more to do with us than with the reality we observe. Explicitly taking all these factors into account and thus debunking the myth of the possibility of neutral, objective, and value-free research, exploratory social science offers a different research program altogether-one that recognizes the importance, and indeed necessity, of philosophy for social-science research, and one that draws the necessary conclusions from the foundations philosophy has laid out.

\section{THE TENTATIVENESS OF INQUIRY}

If "hard" deductive science can only achieve tentative findings and statements whose truths cannot be attested, then we have good reason to reconsider induction. Induction is prone to be incomplete and faulty, as a whole Western tradition of philosophy has demonstrated. However, as it turns out, deduction is equally unable to lead us to "the truth." Worse, while focusing our attention on methodology, deduction makes us overlook the very important problem of situatedness and leaves many crucial assumptions routinely made by researchers unexplained. Deductive, confirmatory research thus throws out the baby with the bathwater. Inductive, 
exploratory research offers a way to save the baby by admitting, up front, that the kind of knowledge it is able to achieve is partial and tentative.

Observations always run the risk of being incomplete and missing important events, and we have no assurance that the world unfolds uniformly, thus permitting us to learn from the past. However, we have good reason to assume that the world unfolds regularly, and if we assume that, then we can learn from past events. If the world stops unfolding in a regular way, catastrophe is the most likely trigger, and we will not need any social science anymore. In the meantime, we should assume uniformity.

Admitting to the tentativeness of findings and explanations of reality translates into making nonexclusive claims about reality. If our theories and hypotheses about the world cannot bridge the gap that separates them from reality, and if those theories and hypotheses have more to do with our own mental, social, and cultural situatedness, then our theories and ideas only allow us to make sense of the world for ourselves. Theory-driven empirical research-and all research is theory-driven - allows the researcher to explain reality so it makes sense to him or her. If successful, an explanation provides a fruitful and plausible way to look at and explain reality that also makes sense to others. It can never be the only possible way to explain it. This, then, leads to a more humble formulation of claims about reality and how reality "really" is. Instead of advancing arguments that make claims to be exclusive truths, exploratory research provides more or less plausible and hence fruitful ways to examine and explain reality that can be shared, if successful and plausible, after a critical evaluation. In this way, competing and even rival explanations can coexist. This does not automatically lead to relativism. In exploratory research, there are better and worse explanations. What are the criteria?

Good and valid explanations in exploratory research are those that are able to demonstrate the robustness and plausibility of the link that connects a stipulated cause to an effect. If I can demonstrate how exactly investment in education led to economic growth in a given country over a given period of time, then I am doing a good job at explaining this claim, while being aware that education is not the only cause for economic growth. Exploring the relationship between education and economic growth thus means revealing and unveiling the causal mechanisms that connect one to the other. This can only be achieved by formulating theories and hypotheses up front. 


\section{A PRIORI THEORIZING}

The advantages of a priori theorizing and hypothesizing explained above apply equally to exploratory research. There is no theory-free perception of the world, because we can only relate to the world by applying our own mental categories, words, and frameworks. We simply do not see those things we do not understand. Hence, a pure exploration that starts from scratch is impossible. It could only be achieved by someone analyzing a world unrelated and disconnected - thus not ours. Exploratory research, similar to confirmatory research, thus needs to start from an explicitly formulated theory and clear and precise hypotheses. Different from confirmatory research, however, exploratory research does not set out to test these hypotheses, because they cannot be tested and proved to begin with, as Popper has shown. Instead, exploratory research asks how much a given theory and a derived hypothesis can explain, and how well it can explain it, or how much sense this explanation makes. Exploratory research is successful if a previously formulated theory and hypothesis explains a lot, or if it explains very little but explains it very well, thus providing a very valid explanation by elucidating a very strong connection linking a cause to an outcome. In addition, exploratory research seeks to provide new and previously overlooked explanations, and it can do so by actively engaging the researcher in a process of amplifying his or her conceptual tools and allowing him or her to pose new questions and provide new explanations by looking at reality from a new angle. If research depends critically on our own mental models, available categories, theories, and concepts, then better research can be achieved by amplifying the mental analytical repertoire of the researcher. This process is one rightfully called "conscientization." It is strongly and directly related to education, more precisely the German Bildung — that is, general, historical, reflexive understanding.

To provide a more detailed and complete introduction to exploratory research in the social sciences, I will focus on some of the aspects highlighted above in more detail, and provide some examples to illustrate this approach.

\section{FROM WORDS TO REALITY}

Language interferes with our lives in many ways. By wording things, we give them reality (Searle 1997). As Immanuel Kant demonstrated long ago, by categorizing phenomena, we create order in the world while not being 
sure if the world has any intrinsic order outside of our categorizing and naming activities. But this is not a philosophical essay, so there is no need to address this question and resolve this puzzle here. However, the insights produced by such authors as Immanuel Kant, John Searle (1997), and Peter Winch (2008), among many others, must produce an acute awareness that language and reality are strongly intertwined, yet separate, realms. To confound language with reality is committing a mistake, as all those who grasp Wittgenstein even just a little bit will understand. Social scientists cannot afford to ignore this. Language functions as a separate, autopoetic system, thus reproducing itself, as both Ludwig Wittgenstein (2009) and Niklas Luhmann (1996) have demonstrated.

However, language, even though it functions as a self-referencing system, is connected to reality in important ways. Words refer to reality. Words allow us to make sense of an overly complex and chaotic world-a world that, as I mentioned above, might not make any sense on its own and might not be well ordered, despite the old Aristotelian belief that the physical world has an ordering and even developing principle within. We don't really know, and I fear we will never be able to find out-simply because we cannot escape our linguistic grasping of the world, our attempts to explain and categorize it with words and through language. We cannot think, in other words, about the world without using the very references we have created, such as "world," "sense," "order," "before and after," "development," "evolution," "people," "social groups," among others.

Words not only help us explain and make sense of the world by ordering it, hierarchizing it, and putting it into neat categories to which we then attribute causal relationships; words also create realities, and they restrict the possibilities of action. Let me explain: The creative potential of words has been called "constructivism" in some of the social sciences (e.g., by John Ruggie [1998] and Alexander Wendt [1999] in international politics). In sociology, the insight that reality is socially constructed is older and goes back to the work of Edmund Husserl, Alfred Schütz, and Peter Berger and Thomas Luckmann (1966). The philosopher John Searle (1997) has convincingly and systematically demonstrated how, and under what conditions, speech acts create institutional facts. He has argued that "Because the constitutive rule enables the function to be imposed on a speech act, then just performing that speech act in appropriate circumstances can constitute the imposition of that function, and thus will constitute a new institutional fact" (Searle 1997: 54). ${ }^{1}$

To understand reality as socially constructed merely means to be aware that there are no unmediated facts - that whatever action we can think of 
is first perceived by someone, then interpreted, and finally used in the perceiver's own effort to make sense of it by placing it within a framework of available references. Feminist epistemology, as presented by such authors as Donna Haraway (1988) and Sandra Harding (1991), has long pointed this out, along with some sociologists of knowledge (e.g., Latour, Woolgar, and Salk 1986).

This means that the models, ideas, and theories we know and understand condition the way we perceive reality, or even what reality we perceive (Musgrave 1993). If the analytical tools that we derive from our theories and ideas about the world, consciously or unconsciously, only explain one way to "read," understand, and make sense of our sensorial impressions, then this will be the only way we perceive and understand reality, or this will be the only reality we get to know and understand. If, to give an example, we understand the world in terms of "race," then race is what we will see. The same is true for class, gender, religious belief, or such concepts as markets, equilibrium, etc.

The task at hand, then, inspired by Paulo Freire (1993) and Jean-Paul Sartre (1994), is to amplify and broaden our conceptual tools and thus be able to see more, more sharply, more accurately, and from different angles or positions. Hence, proposing new words, concepts, theories, and hypotheses allows us to analyze the new realities to which those new words and concepts refer. By looking at and analyzing reality from a different angle, we can hope to unveil previously hidden facets of reality-if we are able to demonstrate the plausibility and strength of the connection our new approach establishes. This effort is at the core of exploratory social-science research.

This sort of work, by its very definition, is inductive. Its end result is that by broadening, amplifying, and diversifying our conceptual tools and frameworks, we will be able to perceive more, better, and differently, being able to make sense out of that which previously struck us as nonsensical and simple white noise. This task becomes a bit more complicated when our interest lies in human (that is, social) behavior, because human interaction is inherently social and thus meaningful, and it thus constantly requires interpretation and understanding (Gadamer 1994).

\section{AN EXPLORATORY RESEARCH PROGRAM}

We can spend hours debating what "democracy," or "citizenship" really is. But this discussion is beside the point. What exploratory research focuses 
on is what reality a word like "democracy" refers to. What does democracy mean in Colombia today? What does it mean to a poor campesino, a black Chocoano, or an indigenous tribe member from Vaupés? We need to dissect, to analyze by pulling apart, words from the reality they refer to, and as exploratory social scientists, we should focus on the reality, not the words. This means, in most cases, that we need to look for indicators that tell us something about the reality represented by a word.

This sounds easy enough. However, the trickiness of words and language goes further and tends to confuse us at deeper levels. Think about a word like "class." What reality does it refer to? Do classes "really" exist? Some words clearly have structured our thinking so much that we use them not only to talk about the word and make sense of it, but to guide our actions - and to construct our identities around them. Identity construction, after all, is also a discursive process - one where we assemble those elements that we recognize as relevant and use them to construct who we are and who we want to be. To some extent, we assemble our identities with words, using categories that have proven helpful to us in other contexts. We think we are "rooted"-because rootedness resonates with what we want to be, what makes sense to useven if such a concept is borrowed from a non-human realm (Stepan 1986). Think of the word "race" and you get a sense of how much such a category has offered some of us in terms of ordering the world, and ordering our own thinking about who we are and how we differ from others.

When doing exploratory research, we need to remain alert to the pitfalls of reification and avoid any tendencies to essentialize words and categories. Instead of looking for the essence behind a word or concept, we need to explore what aspect of reality this word opens up for us, and what a specific word allows us to see, or what aspect of reality it refers to.

In terms of research design, this necessarily implies that instead of pretending to be neutral, we need to be aware, explicit, transparent, and honest about our starting position, standpoint, situatedness, or positionality. This, in turn, requires that we formulate theories about the world, about how things relate, first, before we initiate any empirical research. We have to propose a structure of order-an angle, if you will—that allows us to look at the world in a certain way, or through a certain lens or prism. This, again, is necessary because there is no neutral or clean-slated perception of the world, as our perception of reality is influenced and indeed conditioned by the mental structures, ideas, and theories we already hold about the world. We only perceive what we already know, what is familiar to us - or in the words of systems theory, we only perceive that which we recognize as meaningful and patterned, that which makes sense to us. This is why pure discovery 
of reality is impossible to us. We are utterly unable to look at the world "theory-free" as we cannot escape approaching reality through words and categories.

The next best thing to pure discovery and induction, thus, is a gradual extension and widening of our perception and understanding of the world, parting from what we already know and have understood. This process requires the explicit, up-front formulation of explanatory models - that is, theories. $^{2}$

\section{WHAT ARE THEORIES FOR?}

Theories are tentative explanations about how the different elements of the world relate to each other and why. This is not to say that they actually do. Theorizing about-and hence explaining — the world is an effort to make sense out of it by ordering it and putting it in causal sequence. Doing so allows us to shed light on a segment of reality by offering a way to fruitfully interpret discrete events and thus connect them. Good theories lead to good questions - and good questions allow us to discover new aspects of reality. The good question never is "how it really was" - or "what really happened." What really happened will differ for everybody involved-and all those involved will only understand what "really" happened after someone has offered a way to explain it after the fact—and others have accepted this explanation and the implicit framework that comes with it (Goldstein 1983). Once we are aware of the theoretical models and assumptions that guide our approach to reality, we can then expand and ask different and new questions that allow us to explore the empirical terrain that surrounds the empirical segments we initially focused on. Exploratory research thus becomes an act of gradual, structured, and theory-led heuristic expansion from an original set of models, explanations, and questions. It does not start from scratch.

In this context, the good question is one that allows us to see plausible connections that have previously not been seen, explored, or understood. Words, because they evoke certain realities, become functional in this endeavor. As words are separate from reality but refer to it in different ways, as argued above, new and different words, categories, concepts, models, and theories promise to allow us to see new things, or to see old things in a different way. Theories thus cannot be true or false, as they have no ontological status. As thought models, they can be more or less helpful and 
supportive of our constant effort to explain the world by making sense of it (Popper 2002).

Take the example of such a central social-science concept as "citizenship." Instead of explaining what it "really" means, I propose to engage in an effort to offer new ways of looking at those aspects of reality that fall under the very broad label of "citizenship." For example, one can think about something like "second-class citizenship" not because it really exists, but because such a concept allows us to explore some easily overlooked corners of the reality represented by this word. One might also think of citizenship as a social role, because thinking of it in that way allows us to explore the roles and expectations we commonly associate with this term. Finally, think of citizenship as a good, or an asset-again, not because I think it really is that, but because this allows us to explore an aspect of citizenship that is crucial to its reality and has not been captured and explained well: namely, that citizenship is worth something, and it might be worth more if not everybody has access to it. Finally, think of citizenship as something inherently conflictual, embattled, disputed, internally contradictory—and produce your research design accordingly — and chances are that you will be able to unveil new aspects and facets of what kind of reality the word "citizenship" represents.

The purpose of doing this is to unveil the different ways in which different people and groups live, experience, and invest the word "citizenship" with different meanings, and how citizenship is negotiated, embattled, defended, or upheld and substantiated in social reality and daily praxis. This is, in my mind, the most that honest social science can achieve. There are no hard rules or laws to be discovered in social life, and the establishment of such hard laws and rules comes with a great cost to validity: we can always only measure the easy things, or the easily measurable aspects of very complex social phenomena. We can find great rules and laws-that apply to very little. Or, as I propose here, we can content ourselves with detecting new and fruitful ways to look at and analyze reality, none of which should lay claims to be exclusive or true-at least not truer than another, equally fruitful way to analyze reality.

SOME PRACTICAL RULES FOR CONDUCTING EXPLORATORY SOCIAL SCIENCE RESEARCH

In exploratory social science, the choice of cases is not random. It is predicated by the logic of analyzing the richest, most telling cases and unveiling 
the thickest and most telling connection between two variables. Such a study is, in a strict use of the term, not a comparative case study, where cases are used to simulate experimental research settings. Instead, cases are chosen so that each single one can tell a lot about the underlying conditions and causal mechanisms at work. Instead of focusing on overlap and similarity on the independent or dependent variables, exploratory research seeks to detect causal mechanisms, that is, causal propositions that link independent to dependent variables. Cases are selected to shed the most light on the specific causal mechanism in focus. The guiding question for such a procedure is: where can I see and explain this best? Or, in what case is this causal mechanism most evident?

This methodological choice is driven by several insights. First, exploratory studies allow us to think, not just measure-to use our imagination, experience, insight, and skill to propose new and innovative ways of understanding and interpreting reality. This is, to me, a very important component of being a social scientist. The best scientists we have had were not the bureaucratic-minded number crunchers that now dominate some of our disciplines. Especially in the social sciences, the best of us have been able to infuse and enrich their work with their life experiences, travels, and innovative ideas. Think of Alexis de Tocqueville as maybe the prime example of a thoughtful and insightful analyst, who proposed new and innovative ways of thinking about democracy after traveling for almost one year in North America with his friend Gustave de Beaumont. Or think of Karl Marx, whose proposal to think about the unfolding of history in terms of economic power and asset ownership has influenced the thoughts and actions of millions. Exploratory social science has been more influential by far than confirmatory social science. It has given ideas, inspired, helped understand reality in new ways, and shed light on previously not understood phenomena. It has provided new and innovative readings and interpretations of the world, or facets thereof, without being able to test and predict the hypotheses it has advanced.

Second, exploratory work can be done rigorously. Whenever this is achieved, it promises to attain a degree of validity that is beyond the wildest dream of any confirmatory researcher, especially researchers relying on quantitative methods. As stated above, to be rigorous, exploratory work needs to be honest and transparent. It also demands a high level of selfreflexivity from the researcher (Alvesson and Skoldberg 2009). However, to be rigorous, exploratory work needs to take into consideration the findings about epistemology and perception that different philosophers have elaborated on. As explained above, the core insights are that we cannot approach 
reality theory-free. Our very perception, that is, what we perceive as meaningful and how we perceive it, is influenced by what we already know-our preconceived ideas about the world. If we do not know what a cuacuco is, we will never see one, never recognize one-even if it passes right in front of us. Without the idea of a cuacuco, the sensorial information of a cuacuco is nothing but white noise to us. However, once we know, we will perceive the passing cuacuco; see it, because we can now make sense of this sensorial information; put it in the category "fish," and recognize it as such. To perceive the world, in other words, we must rely on previously established ideas and theories and we can then expand from there. Once we know the cuacuco, we are also able to compare and contrast it to other fish and learn more about the fauna of a given river (Lakoff 2009; Haraway 1988). We have no other choice but to always initiate our inquiries from an already formulated theory.

Popper (2002) holds that epistemology must only concern itself with examining the logical consequence and coherence of new ideas, not where they come from, which is the task of psychology. Placing something outside of the realm of legitimate reflection does not solve the problem; it simply avoids it. His own theory of perception and anticipation, called the "Searchlight Theory" (Popper 1974), nevertheless offers an explanation on just how new ideas are conceived, namely, through the comparison of new sensorial information with already available knowledge-which leads us to anticipate according to past knowledge in a movement of problem-solving trial and error.

No matter how this epistemological problem is solved, the debate about it makes clear that we have an innate tendency to anticipate, based on the limited information we have at our disposal. Under conditions of a lack of a secure and validated paradigm that would allow us to deduce research questions and programs, we must instead embrace our tendency to anticipate and formulate clear and testable - that is, falsifiable-hypotheses, instead of avoiding it. That way, we can put our own anticipations, which spring from our previous experiences and already accumulated knowledge, to the test and ask how plausible they are- that is, how much and how well they explain. This process, if conducted honestly and transparently, allows us not only to accumulate knowledge about the world by dwelling on our already gained knowledge and experience-it also makes a collaboration of scientists possible. If we reach our tentative extrapolations and explanations in a transparent way, we can evaluate them critically-and expose them to the critical evaluation of others. This is what science can achieve at its best. Reaching tentative explanations gained from our previous work 
and experience also provides a much more plausible rationale for reaching new explanatory models than the deus ex machina mechanisms that Popper (1974, 2002) proposes as a replacement of what he calls "psychologism." Indeed, we cannot explain the emergence of new explanatory models with reference to our own cognitive or psychological structures, just as we cannot rule out the risk of cognitive solipsism. Structured, self-aware, critical, and transparent anticipation, however, is not only what we should do as scientists. It is also what we do as human beings: building on previous knowledge, gradually expanding it, and proposing new explanations that are derived from our previous knowledge. The knowledge we can obtain in this way is indeed not 100 percent reliable, as we cannot truly count on a uniformly evolving history. It is, instead, tentative and subject to critique, revision, and all sorts of methodological errors-but this is precisely what we are able to achieve. Claiming to achieve more reliable or more valid knowledge about human behavior and interaction actually achieves less.

What we can achieve, different from the natural sciences, is to discern, describe, and explain causal linkages and mechanisms that connect two or more relevant variables in significant ways. Once this is done, we can establish an if . . then . . relationship that describes a likely pattern or a probability of consequence, if certain conditions are met or already in place. It is this sort of limited (or better delimited) and structured anticipation that makes explicit use of available theoretical models and explanations and then relies on finding supporting empirical evidence in order to avoid the pitfalls of an extreme skepticism, that promises to advance our insight and understanding of the social world. It has this potential because it allows us to see and understand social reality in different ways, and from different angles. If done cumulatively, social science can then contribute to a more complex and complete reading of social reality_and might even aspire to contribute to the very real process of conscientization that should be initiated in schools and continued systematically in universities. ${ }^{3}$

The knowledge produced in such a way could also be of more utility to everyday life than the highly formalistic and extremely technical procedures activated to conduct confirmatory research today. Most of the techniques that produce and calculate probabilities of correlations are so sophisticated that they take up most of the space, physical as well as intellectual, of confirmatory research production and its debate. It is in this process of describing and explaining not reality but methodology that most social scientists end up losing most laypeople, as well as uninitiated specialists. Such proceedings would be justifiable if the findings about laws and regularities would really fall within the realm of the possible in the social sciences-but they 
do not. As explained above, social life is far too contingent and in flux to be captured by rules and regularities. Put simply: laws do not apply in the social world - and thus should not be sought for in the social sciences.

The consequence of all this simply is that exploratory, inductive research can achieve reliability under certain conditions. Proceeding in such a way allows for a clearly defined starting position in the process of knowledgebuilding and gaining understanding and familiarity with a subject or problem. It also allows for a delimitation of the empirical field that is relevant to a given research question - as purely exploratory research would otherwise be endless and lead into the traps of infinite regression.

Different from a purely deductive research design, such a proceeding also allows for a revision of the initial hypotheses, and even for the reformulation of the research question-in a process of slowly and gradually making oneself familiar with all of the phenomena associated and related to the problem in question. This deductive-inductive research design thus starts by entering a hermeneutic cycle of creating understanding and expanding this understanding up to the point where all the phenomena related to a given problem and research question can be explained (Gadamer 1994).

Induction thus becomes part of a deductively initiated research project and allows for a pressing forward of findings up to the point where the causal mechanism previously established through a theoretical framework is explained. In other words, the outer limits of how far such a research process should reach need to be established by a previously formulated theory and hypothesis, as otherwise this process would be endless. This research process ends not when "everything" is explained (which is impossible), but when the research question is successfully answered.

The exploratory character of social-science research refers to the very domain of what can be detected, described, and explained. Given that our naming, wording, categorizing, and hierarchizing of the world is intrinsically linked to our perception of the world, all we can aspire to as social-science researchers is to offer new categories, models, and theories that allow us to analyze a specific phenomenon in a new and fruitful way. Instead of examining the content of words and categories, our efforts should be geared towards holding interpretative models and reality apart and thus avoiding the pitfalls of reification that lurk at almost every corner of inquiry into a meaningfully structured social reality. If we did the structuring in the first place, we should not take our own categories as given, or invest them with an ontological status they have only acquired through our own action of naming. Instead, we need to propose new, or newly composed, models that approach reality differently, in new and innovative ways and from different angles. As 
social reality constantly changes, this endeavor is endless, as someone else can describe and explain the same segment of reality I have described today differently tomorrow. However frustrating this might be, it is the only way to produce truly reliable knowledge about the social world-a world that is socially constructed and reproduced continuously by the same people who seek to explain it.

In a strict sense, exploratory research, just like confirmatory research, is thus only able to test the strength and plausibility of a causal link previously established by a theory or model—hence by the researcher. This makes any research self-referential. Instead of exploring the world, scientific inquiry in the social sciences only tests the validity, reliability, or to use less technical terms, robustness and strength, of previously established causal links, which are derived by theoretical models and hypotheses. This implies that any research project can only claim to examine one explanation at a time.

This automatically means that the given explanation is never the only explanation possible. Reality is far too complex for such a claim. A scientific explanation rather provides one way to look at reality, one way to make sense of one particular segment, previously established, of reality. It necessarily simplifies and it can never claim completeness, as social reality is in constant flux, thus creating new constellations that can be examined and explained differently, from different angles and by using different prisms. "Really" or "fully" explaining something is thus impossible. Exploratory research is over once the empirical reality referred to by a concept or theory is explained so that "it makes sense" to the researcher. Such an explanation is successful if others find this individual sense-making effort fruitful, helpful, or insightful, so that his or her sense-making overlaps with theirs. ${ }^{4}$ The practical process of conducting exploratory research thus necessarily follows the pattern of the hermeneutic circle, as described by Hans Gadamer (1994) (see Reiter 2006).

THE EMANCIPATORY POTENTIAL OF EXPLORATORY RESEARCH

Exploratory research has an inherently anti-authoritarian and anti-dogmatic potential, because in most cases it does not require the mobilization of, and payment for, a huge research apparatus the way that most "systematic" confirmatory research does. Confirmatory research, because of its claim to be systematic, in most cases requires much time, effort, and money, which is 
why most systematic research projects are conducted by scholars working at elite universities, who receive funding from highly selective, and highly disciplining, funding agencies such as the National Science Foundation or the Social Science Research Council. The review processes involved in selecting research projects and publications almost never support "unsystematic" research, which in most cases translates into research not conducted within the established, quantitative confirmatory paradigms. Disciplined in such a way, it comes as no surprise that new findings are rarely produced. The stifling process of review by powerful and hegemonic mainstream institutions and "peers" if anything narrows the array of what is possible and doable in the social sciences. They function as a disciplinary power par excellence (Feyerabend 2010). Indeed, as Paul Feyerabend has argued, "Twentiethcentury science has given up all philosophical pretensions and has become big business. It no longer threatens society; it is one of its most powerful supporters. Humanitarian considerations are at a minimum, and so is any form of progressiveness that goes beyond local improvements. Good payment, good relations with the boss and colleagues in their unit are the chief aims of these human ants who excel in the solution of tiny problems but who cannot make sense of anything transcending the domain of their competence" (Feyerabend, quoted in Motterlini 1999: 114).

It should not be surprising that the most systematic research seems to originate from ivy-league professors. The same researchers able to conduct expensive research projects are oftentimes also involved in the decision making about who should receive funding for what sort of research, so that the whole enterprise runs the risk of becoming self-serving, narrowing down what research is.

Exploratory research, to the contrary, does not require the mobilization and payment of big research apparatuses. It can be conducted alone, oftentimes with nothing more than access to a library and a voice recorder. It often involves travel and knowledge of another language, thus demanding more intellectual preparation and courage to expose oneself to other peoples and cultures from the researcher, yet less money and institutional support. As such, it offers interesting opportunities, especially for young researchers and graduate students, who otherwise have to rely on the disciplinary power of their senior colleagues. In short: exploratory research has emancipatory potential and promises to unveil new relations and causal mechanisms that escape the disciplinary scrutiny of the established research apparatus. ${ }^{5}$ 


\section{DIALECTICS}

A strong rationale for choosing an exploratory research design is that exploratory social science has the potential to be more insightful than confirmatory research by applying dialectical thinking. Dialectics, explains Theodor W. Adorno (1973), means "to achieve something positive by means of negation" (Adorno 1973: xix). The systematic treatment of dialectics goes back to Georg Wilhelm Friedrich Hegel and his Phenomenology of Spirit, first published in Germany as part 1 of his System of Science in 1807. Hegelian dialectics has three components-namely, circularity, where all existence is constituted by its own negation, thus forming a whole only through this circle; the contradiction and its resolve (Aufhebung); and idealism (Sarlemijn 1971: 4). In 1841, the young Karl Marx famously "put Hegel back on his feet" by stripping his work of its idealistic component and proposing a dialectical materialism instead (Marx [1841/42]: 1971: 28). It is this version of dialectics that inspired the critical theorists of the Frankfurt School, especially T. W. Adorno, Max Horkheimer, and Herbert Marcuse. Instead of Hegel's ontological dialectics, what interests exploratory social scientists today is the analytical methodology that emerges alongside its ontological counterpart. ${ }^{6}$

According to Marcuse (1960), "The power of negative thinking is the driving power of dialectical thought, used as a tool for analyzing the world of facts in terms of its internal inadequacy. ... 'Inadequacy' implies a value judgment. Dialectical thought invalidates the a priori opposition of value and fact by understanding all facts as stages of a single process - a process in which subject and object are so joined that truth can be determined only within the subject-object totality. All facts embody the knower as well as the doer; they thus 'contain' subjectivity in their very structure" (Marcuse 1960: viii).

In other words, there can be no objective or neutral social science, because the researcher is always and automatically involved and implicated with the object and the subjects of his or her inquiry. Dialectical thinkingthat is, thinking about inherent contradictions, and understanding progress not as a linear process but a gradual unfolding of oppositional forcesprovides a fruitful way to conduct social science, even more so if and when social scientists accept that they themselves are part of history's unfolding and deeply involved in the reproduction of the knowledge they seek to analyze, which is what Marcuse suggests in the quote above. A prime example of such thinking is provided by Karl Marx and Friedrich Engels (1848) in their attempt to describe and explain the revolutionary power of markets in 
the Communist Manifesto, as well as by Horkheimer and Adorno's (1944) Dialectic of Enlightenment. Both books, despite their shortcomings in terms of producing adequate predictions about the future, still stand as powerful diagnoses of our times. The depths of their insights have secured these documents a place in history. Consider, for example, this passage from the Dialectic of Enlightenment:

In the enlightened world, mythology has entered into the profane. In its blank purity, the reality which has been cleansed of demons and their conceptual descendants assumes the numinous character which the ancient world attributed to demons. Under the title of brute facts, the social injustice from which they proceed is now as assuredly sacred a preserve as the medicine man was sacrosanct by reason of the protection of his gods. It is not merely that domination is paid for by the alienation of men from the objects dominated: with the objectification of spirit, the very relations of men — even those of the individual to himself-were bewitched. The individual is reduced to the nodal point of the conventional responses and modes of operation expected of him. Animism spiritualized the object, whereas industrialism objectifies the spirits of men. Automatically, the economic apparatus, even before total planning, equips commodities with the values which decide human behavior. (Horkheimer and Adorno 1997: 28)

Horkheimer and Adorno detect in the project of demystifying the world, which they trace back to ancient Greece and term "enlightenment," the very seeds of its reversal into an even worse state of affairs, where individuality succumbs to mass society, and human desires and actions blindly follow the dictates of empty consumerism. Thus the project of rationalization turns into irrationality, and freedom from the powerful grip of nature and vengeful deities, which restricted lives during antiquity, is substituted with an even worse unfreedom: that of the market and the fetishism of products we seem compelled to buy, knowing that they will not bring us happiness or peace of mind.

As this example demonstrates, dialectical thinking aims at exploring the internal contradictions of phenomena. In seeking to do this, one can follow Herbert Marcuse's (1955) prescription, namely, that "Any particular form can be determined only by the totality of the antagonistic relations in which form this relation exists" (Marcuse 1955: 26).

In a slight variation to the initial dialectical tradition, which is still burdened by Hegel's legacy in that it suggests history itself unfolds dialectically, exploratory research uses dialectics as an analytical tool and way to 
look at reality. It does not claim that history itself unfolds dialectically, but that thinking about and analyzing history through the prism of dialectics allows for new insights and angles of observation. When thinking about citizenship, for example, dialectical thinking leads one to look for inherent contradictions and negations that together fall under the label "citizenship," and the reality for which this label stands. Thinking about citizenship in terms of its internal or inherent contradictions thus promises to produce fruitful ways of analysis, allowing for deeper insight and understanding. Such a dialectical thinking about citizenship allows us to go beyond the very common simplistic, dualistic models that dominate the social sciences. Instead of focusing on dualisms and discrete phenomena, dialectics points our gaze towards processes and those connecting elements that link different phenomena, which translates into a search for internal, and maybe inherent, dynamisms, contradictions, and different forces pulling in different directions.

Hence, by approaching reality dialectically, one can analyze a reality of connectedness, entanglements, and mutual continuations, which allows for a depiction of reality as a space where privilege and access are constantly negotiated and fought over. The resulting depiction of reality promises to be much richer and more telling than those strangled by dualistic approachesas Thomas Holt's The Problem of Freedom (1992) or Gary Wilder's The French Imperial Nation State (2005), to name but two supreme examples, can amply attest to.

\section{THE PROBLEM OF THE RESEARCH DOMAIN}

A final, procedural word about the research domain and the unit of analysis of this endeavor is called for, given the differences, maybe even contradictions, between everyday knowledge and language and academic lifeworlds, with their specific and technical language and methodologies.

In exploratory-research design, cases are selected to demonstrate a high level of clarity when it comes to the unveiling of connecting mechanisms and links. They should convey a richness and saturation of empirical information that allows for a clear depiction of how something comes about and why. The implications of assuming such a position from the very start are many, and I shall pinpoint some of the more common and consequential.

When conducting social science under the awareness that the ordering of reality is as much a product of our own minds as a result of the reality 
"out there," then exploratory cases should be selected because they offer analytical richness, not because of their historical specificity. The aim of exploratory research is to establish plausibility among different variables, previously defined by the researcher-not to add to the factual, historical knowledge. Exploratory research is thus firmly committed to a constructivist view of reality. The outcome of a successful exploratory-research project is to propose a new, insightful, fruitful, and plausible way to think about and explain reality-not to detect new material facts.

Furthermore, exploratory research is by its very nature interdisciplinary, and should freely borrow from the various social sciences. It is precisely by adopting, comparing, and trying out a linguistic, ethnographic, anthropological, geographical, sociological, economical, or political-science gaze that new insight can emerge and rich exploration can occur.

CONCLUSION: EXPLORATORY, DEDUCTIVE-INDUCTIVE, AND DIALECTICAL

In this chapter, I have sought to argue and demonstrate that reliable inductive, exploratory, dialectical research can be achieved if conducted in the structured, transparent, and honest way described above. If successful, the findings and insights produced in such a way can help shed new light on phenomena that have already been explained partially and in different ways. Furthermore, if successful, exploratory research can help to conscientize those that read it by unveiling previously unthought-of connections and causal mechanisms. Given that the procedural apparatus able to generate the findings presented here is not a sophisticated computer program or a mathematical model operating at high levels of abstraction, exploratory research also addresses non-specialists and non-academics, offering to them the same sort of knowledge produced from reflexive, self-critical, transparent, and dialectical research. There are no secrets or complicated procedures that require years of initiation. Instead there is engaged dedication to the phenomenon under scrutiny, and prolonged, systematic inquiry-paired with reflection, comparison of different cases, formulation of tentative explanations, revisions, dialogue, and finally, the formulation of new and hopefully fruitful ways to look at the reality represented by such words as "citizenship," "democracy," and the like. 


\section{Conceptualizing Citizenship Disjunctive, Dual, Divided, Entangled, or What?}

Theory is theoria: the gaze that puts us face to face with something and inspects it . . . I can elucidate my relation to language, but I cannot abstract myself from it and "look at" it, nor can I "construct" it from the outside. I cannot make a "theory" out of the institution, for I am on the inside. . . There is therefore a deep-seated dependence, in respect to language, between what I think and what I say.

-CORNELIUS CASTORIADIS, 1985

In his seminal work on Citizenship and Social Class, T. H. Marshall ([1950] 1992) argued that in Europe, civil rights preceded political rights, and once both these rights were achieved, social rights would follow. Marshall predicted that the twentieth century would see an expansion of social rights, which he defined as "the whole range from the right to a modicum of economic welfare and security to the right to share to the full in the social heritage and to live the life of a civilized being according to the standards prevailing in society. The institutions most closely connected with it are the educational system and the social services" (Marshall 1992: 8). For him, the state was called upon to reduce the risks associated with capitalism for the poorest citizens (Jones and Gaventa 2002: 3). As explained by Jones and Gaventa, this state action would lead to an "overarching sense of community and civilization" (Jones and Gaventa 2002: 3).

When the twentieth century came to an end, it became clear that 
Marshall's prediction was too optimistic. In 2012, many European citizens are effectively still excluded from social rights, to the point where some analysts argue that Europe is developing an apartheid system (Balibar 2004). Especially, nontraditional, nonwhite European citizens see their civil rights curbed by the forces of prejudice and racism. In many countries, they are treated as foreigners and intruders despite their legal citizenship. ${ }^{1}$ Instead of social rights following civil and political rights, it rather appears that the exercise of civil rights depends on the previous achievement of social rights, as racism is undermining the effectiveness of civil and political rights of all those stigmatized as "others within."

Racism is at the core of this exclusion, and it is Marshall's underestimation of the power of racism that led him to formulate overly optimistic predictions about Europe's democratic future. In Europe, as elsewhere, racism continues to be functional for the maintenance and reproduction of privilege. Worse, under conditions of increased market competition, characteristic of advanced capitalist systems, the importance of racism might grow. Racism becomes more pronounced when different actors compete for scarce, and thus highly desirable, goods (Winant 2001). Under such conditions, whiteness functions as additional capital, bestowing competitive advantages on those able to claim it with success (Reiter 2010).

\section{CITIZENSHIP}

Citizenship is a broad concept. According to Webster's definition, it is "the status of being a citizen." T. H. Marshall (1992), in turn, defines citizenship as "a status bestowed on those who are full members of a community. All who possess the status are equal with respect to the rights and duties with which the status is endowed" (Marshall 1992: 18). Tom Bottomore, who wrote the essay "Forty Years On," which together with T. H. Marshall's own essay constitutes the publication through which Marshall's work is accessible (1992), already points out that citizenship in our day (his were the days of the 1990s) faces new challenges, some of which Marshall could not have foreseen. Among others, he mentions the problems triggered by increased migration, thus causing greater ethnic heterogeneity among European citizenry and posing new challenges to citizenship. To capture these new challenges, Bottomore proposes a distinction between formal and substantive citizenship — a distinction introduced by Rogers Brubaker (1989, 1992). He quotes Brubaker, who had argued that "formal citizenship is 
neither a sufficient, nor a necessary condition for substantive citizenship" (Brubaker 1992: 36, quoted in Bottomore 1992: 66).

Several authors have disputed the notion of citizenship as a status. For communitarians such as Michael Sandel (1998), citizenship is more than a right, it is an obligation and a calling to participate and actively engage in one's community. Civic republicans, such as Jürgen Habermas (1998), have stressed that what makes one a citizen is the ability to participate in collective decision making and thus fulfill one's role as an active constituent of popular sovereignty. According to Jones and Gaventa, "At the centre of much contemporary writing is the need to conceptualize citizenship as both a status, which accords a range of rights and obligations and an active practice" (Jones and Gaventa 2002: 5). Several authors have since tried to expand the notion of citizenship, and they have proposed alternative ways of conceptualization. Margaret Somers, for example, has defined citizenship as "a set of institutionally embedded social practices" (Somers 1993: 589). More recent treatments of citizenship, e.g., those collected in Tulchin and Ruthenberg (2007), follow this focus on citizenship as a practice. James Holston (in Tulchin and Ruthenberg) proposes "to study the full experience of citizenship, and not only its political aspect" (Holston, in Tulchin and Ruthenberg 2007: 77). In his book Insurgent Democracy, Holston (2008) indeed applies an anthropological framework to the analysis of how citizenship is experienced in everyday life.

However, these recent efforts to adequately capture and explain what citizenship effectively is, and what it means to different people, have not yet produced a conclusive framework, and Frances Hagopian's call (in Tulchin and Ruthenberg 2007) to focus on citizenship, especially when studying such "disjunctive democracies" (Holston 2008) where political and civil rights do not necessarily go hand in hand, still stands.

To be able to do so, we first need a useful analytical framework-a lens that allows us to focus on and delineate what kinds of realities and practices the word "citizenship" stands for. The elaboration of such a framework, able to capture the empirical phenomena and practices associated with the term "citizenship," is the aim of this chapter. "Citizenship" is but a word, and fighting over words, to me, is time wasted. The real question is what the word refers to, what slice of reality is represents, how this section of reality works, and how it articulates with broader society, the state, the economy, inequality, and the like. I shall, hence, be careful to avoid the very common pitfall of reification, as my exercise in this chapter is merely one of conceptual tool building so that they can be applied to examining reality. Conceptual tools help us to analytically separate an overly complex and 
synthetic reality. The categories so created have no ontological status; they do not exist "out there." The scientific game is necessarily one of simplification, reduction of complexity, and schematization aimed at detecting patterns, important connections, and causal mechanisms. The purpose of this chapter thus is to propose analytical tools that allow us to make fruitful and insightful inference into the reality of democracy and citizenship. I will leave the empirical application of this framework for later.

I first propose to accept Brubaker's distinction of formal and substantive citizenship, and in this chapter I shall further elaborate on the meaning of substantive citizenship. What exactly is substantive citizenship, and how can we, as social researchers, assess it? My main argument is that substantive citizenship has two important dimensions—namely, substantive citizenship as a social role, and substantive citizenship as a relational asset. Indicating the relative presence or absence, as well as the quality, of possession on both dimensions allows us to gain a deeper, more specific, more precise, and hence more accurate and valid capturing of the empirical reality represented by the concept of citizenship.

Hence, this chapter proposes that the concept of citizenship and the rights associated with it has two important dimensions yet unexploredor rather, not yet applied systematically to the study of democracy. First, citizenship is not just a legal status; it needs to be a practical and practiced reality for it to have any impact on people's lives. As such, citizenship is associated with a certain role-namely, the role of being a citizen invested with certain rights and duties, and protected by the state that makes and enforces the rules and laws that define citizenship. Citizenship, then, is best understood as a social role, as Brazilian anthropologist Roberto da Matta (1987) has long pointed out and James Holston (2008) has more recently highlighted again. If some citizens are not treated as citizens, citizenship remains an empty concept. Second, citizenship is also an asset, and just like any other asset, it is disputed. As an asset, the value of substantive citizenship is relational-that is, its value is derived from how much substantive citizenship one person or group has, compared to another person or group. Having access to the asset of citizenship when most people do not bestows extra value on its possession. ${ }^{2}$

The main claim I seek advance here, thus, is that we can explore hitherto unexamined realities associated with the concept of citizenship by focusing on its dimension as a social role, and its dimension as a relational asset. Doing so promises to produce answers to what I consider the most important question we need to ask when discussing citizenship-namely, why democracy has gone hand in hand with so much inequality, consistent 
exclusion, and, as a result, a widespread disillusionment with democratic systems worldwide. Focusing on citizenship as a social role and a relational asset promises to provide new, richer, more complete, and more insightful answers to this important question.

\section{SUBSTANTIVE CITIZENSHIP AS A RELATIONAL GOOD}

As stated above, the concept of "substantive citizenship," as proposed by Brubaker and discussed by Bottomore, provides a specification of the more general term "citizenship" as it contrasts with the formal aspects of citizenship. But what makes citizenship substantive, and how can we, as social scientists, assess and measure the amount of substantiveness of citizenship?

The first step in this endeavor must necessarily consist of recognizing and treating substantive citizenship as belonging to the realm of the social. In other words, substantiveness cannot merely be a formal and hence legal issue. Once citizens hold formal citizenship, the question becomes how this formal status translates into everyday practice, and how a formal status of equality under the law is used and applied by individuals and groups in their struggle for social mobility, status, access, and power. ${ }^{3}$ Substantive citizenship is a contested status, and for it to translate into reality, it needs to be defended, upheld, substantiated, and negotiated vis-à-vis the state and other individuals and groups who share the same formal status. To adequately capture this dimension of citizenship, I propose to approach the quality of citizenship by treating substantive citizenship as an asset. The asset dimension of citizenship exposes it to problems of scarcity and competition. To some people it might be worth more when-and as long as-others do not possess it. Citizenship as an asset thus behaves like a positional good, a concept developed by the American economist Fred Hirsch (1976). In a nutshell, Hirsch argues that certain goods only deliver the sought-for benefit as long as not everybody possesses them, and once more people possess them, more goods are needed to fulfill the same function. Educational degrees are a case in point. If everybody has a college degree, having a college degree no longer guarantees access to good jobs, and educational requirements will rise. Hirsch points out that in advanced capitalist markets, competition for "positional goods" increases as capitalist development advances. According to Hirsch, positional goods derive their value not from their absolute utility, but rather from their relative position to others. At the same time, the costs 
in terms of investment required to have the same outcome steadily rise, in a process he calls "screening" (Hirsch 1976: 41).

A very important corollary of this theory is that those who have a historical advantage will always lead the race for more restricted goods. As Hirsch demonstrates, the maintenance of the privilege of access resides on a better starting position. When applying this insight to the relational good of "scenic property," Hirsch explains that "What matters in the acquisition of scenic property is less one's own present income than the present and past incomes of other people. To secure the objects in the auction catalogue, it is relative rather than absolute income and wealth that count. A head start in this competition for relative ascendancy accrues to those who acquired such assets in earlier, less expensive auctions" (Hirsch 1976: 36).

This logic, I contend, applies not just to real estate and education, the cases Hirsch focuses on. It also characterizes access to substantive citizenship, because one can get more out of being a citizen if others do not share the same status. On a more concrete level, this logic has already been applied to the job market, where Roediger (1999) has demonstrated that ethnicity has helped American whites to secure access to scarce jobs. We are also becoming more aware that the, at times, vehement reaction against affirmative action can be explained by this logic, because affirmative action undermines the advantage that historically privileged groups have been able to accumulate, thus providing them with a better starting position (Brown et al. 2003). Applying this concept to the case of citizenship in general, we can deduce that thinking about citizenship as a relational good allows us to understand it as a competitive practice. Seen under this lens, if everybody has access to the same rights, then those rights lose value. This way of thinking about citizenship makes it possible to make sense of its exclusionary character by focusing on its internal contradictions and inherent tradeoffs. Analyzed in such a way, it becomes clear that for the historically privileged, rights were never perceived as equal rights for all, but rather as a privilege for themselves, and at best a favor granted to dependent others. Equal rights threaten to undermine the whole patron-client system that allows the privileged not only to perpetuate their own advantage, but to transform the underprivileged into their servants and clients. Stated bluntly, rights are worth much more if they are privileges. Not only do privileges reduce the number of equals and thus reduce competition; they also ensure the reproduction of clients-dependent people who can be used, exploited, or rewarded depending on one's likings and needs. If rewarded, of course, clients can become loyal subjects and potential supporters and thus a highly valued resource in any system that relies on the support of others. In the 
language of Hirsch, "Positional competition, in the language of game theory, is a zero-sum game: what winners win, losers lose" (Hirsch 1976: 53). Furthermore, this author explains that

What the wealthy have today can no longer be delivered to the rest of us tomorrow; yet as we individually grow richer, that is what we expect. The dynamic interaction between material and positional sectors becomes malign. Instead of alleviating the unmet demands on the economic system, material growth at this point exacerbates them. The locus of instability is the divergence between what is possible for the individual and what is possible for all individuals. Increased material resources enlarge the demand for positional goods, a demand that can be satisfied for some only by frustrating demand for others. The intensified positional competition involves an increase in needs for the individual, in the sense that additional resources are required to achieve a given level of welfare. In the positional sector, individuals chase each others' tails. The race gets longer for the same prize. (Hirsch 1976: 67)

I agree with the logic this analysis unveiled over thirty years ago, although I contend that Hirsch's approach was too cautious. The positional logic does not just characterize late capitalist markets, as he thought. It indeed characterizes a majority of human interaction-whenever this interaction is competitive. Most goods and assets are indeed worthier the scarcer they are- which is what makes them worthy in the first place. Hence most goods are positional in that they benefit from being exclusive.

This insight is based on my reading of such authors as Norbert Elias (2000), who has argued that what is called "civilizational progress" is indeed a struggle over cultural forms and norms in a constant striving for distinction and the production of privilege. Privileged groups constantly invent new mannerisms, mores, or customs, not because they are qualitatively better, but because they serve the purpose of setting themselves apart from the mainstream. As soon as elites invent such new forms and manners, the middle classes seek to imitate and copy them in order to claim in-group status. Hence, to some extent, the form is the content; emulating and adapting upper-class behavior constitutes the upper class. Furthermore, according to Elias, forms, manners, and customs fulfill important gate-keeping functions, as they are able to regulate who rightfully belongs and who does not.

Another basic insight about the social world as one constituted by a continuous struggle over privilege, where individuals and groups use whatever means they have at their disposal, comes from Pierre Bourdieu. Bourdieu (1987) very convincingly shows that the social world is indeed reproduced, 
structured, and hierarchized through the constant efforts to position oneself higher up on the social structure based on one's material possessions (financial capital) as well as symbolic capitals (social, cultural, and, I suggest, racial), via the idea of habitus, that is, the way one consumes and displays, or performs, this consumption.

According to Henri Tajfel, group difference and identity are constituted together. This insight goes back to Hegel's discussion of the master-slave relationship. According to Tajfel (2010), groups constitute themselves in relation to other individuals and groups. A sense of identity is fostered through the drawing of borders that separate those inside from those outside. This drawing of borders not only permits the effective separation of one group into two or more, it also constitutes each group with reference to the others. Tajfel's main dialectical insight was that one group can only exist by defining itself as different from another.

Furthermore, as Rogers Brubaker has demonstrated, groupness is a variable and not a constant. As such, it cannot be presupposed. Brubaker (2004) argues that we should think of groupness as events and projects, oftentimes proposed and pushed through by "ethnopolitical entrepreneurs" and the organizations they control and manipulate. Behind many of these group projects stand very tangible power interests. Brubaker also highlights the potentially tricky relationship between groups and categories-be they social-science categories or census categories. He asks, for example, "how categories become groups."

Taken together, these authors present a vision of the social world as one of perpetual struggle over positional goods, assets, or capitals, which individuals and groups use to position themselves higher up on the social hierarchies of their societies. By doing so, those same social hierarchies are created and molded-hence the overlap of form and content - in a process that Anthony Giddens (1986) has called "structuration."

Applied to the study of citizenship, these basic insights about the working and constitution of the social world lead me to think about citizenship as a relational asset. As such, its value is constituted by the fact that its possession is not readily accessible to all in the same amount. From this perspective, substantive citizenship is best described as a contested good, which implies that those who have citizenship have strong incentives to ensure that not everybody is able to substantiate their citizenship, transforming it into effective claims. If this logic applies, then we are likely to end up with a spectrum of citizenship, with first-class citizens on one end and second-class citizens on the other. With increased international exposure and interdependence, there is no reason to believe that the competition for substantive 
citizenship will not assume global dimensions and become more embattled as the world is growing closer together. After all, substantive citizenship is a very desirable asset that most people on this globe want to possess, or possess more of, in those countries where citizenship has already reached high levels of substantiation. As the competition over citizenship sharpens, there is no good reason to believe that we will eventually reach a point where most of the world's population enjoys equal access to substantive citizenship rights. There is, to the contrary, more reason to believe that the struggle over substantive citizenship will get harsher as more people compete for the rights, privileges, and entitlements it promises. ${ }^{4}$

A complicating, yet important question with regard to the asset character of substantive citizenship leads away from analytical frameworks towards empirical reality. The analytical conceptualization of substantive citizenship as an asset is so powerful because it allows one to make sense of historical developments. When applying this lens, one is able to see how citizenship has indeed undergone a gradual change from being considered an obligation and responsibility, to a right and even an entitlement. John Pocock, as discussed below, has hinted at this change of the original Athenian meaning of citizenship as early as under the Roman Republic. Such authors as Hannah Arendt have also pointed out that citizenship has lost its original meaning of a public obligation and become a mere right, for which citizens now seek enforcement. Although there is not enough space to examine how exactly citizenship lost the component of responsibility and obligation, the end result of such a development is that once transformed into a right without obligations, citizenship has indeed become a commodity and an asset that can be requested. In the extreme case, probably experienced in its purest form in the contemporary United States, the rights associated with one's citizenship have indeed become commodified to such a degree that their enforcement is advertised by the media. U.S. lawyers thus actively seek to recruit all those whose rights have been violated so that they can help them reclaim them (and make some money in the process). In terms of a genealogy of citizenship, this represents a thorough transformation of citizenship as a public obligation, which grew out of being a full member in a polis, to citizenship as a social status (as described by T. H. Marshall), to the kind of citizenship that characterizes most contemporary liberal democracies, namely, citizenship as an asset. 


\section{SUBSTANTIVE CITIZENSHIP AS A SOCIAL ROLE}

Substantive citizenship is not only relational. By locating the domain of struggles over its effectiveness in the social realm, we need to take a closer look at citizenship as a practice that relies on mutual validation. Some citizens, even though the state grants them equal rights, might still face difficulties when exercising those rights because they suffer from restrictions created by fellow citizens. Hence, any discussion of citizenship must address the question of whether citizens are respected and treated as citizens-not just by the state, but also by their fellow citizens. To adequately capture the effectiveness of citizenship, we necessarily enter the social domain, where access, respect, and status have to be negotiated among citizens in their daily routines, and their meaning has to be substantiated by daily practice.

Substantive citizenship is also very fruitfully analyzed as a social role that needs to be learned, accepted, and validated by others. Roberto da Matta (1987), writing about Brazil—where the struggle for citizenship rights has long occupied social movements and produced many academic treatises about the limits of citizenship, as well as its different contestations-has pointed out that citizenship is indeed a social role and, as such, it needs to be learned. According to da Matta, Brazilians treat anything related to the state with suspicion, even the role of being a citizen. During his empirical research, conducted during the late 1980s in Rio de Janeiro, da Matta found that Brazilians always used the word "citizen" in negative situations, to demarcate the position of someone who is at a disadvantage or inferior. Da Matta further found that invariably, Brazilians, when asked, "How would you classify a person who obeys the laws in Brazil?" answered negatively. The general tone of the answers provided to this question, according to da Matta, was that a person who follows the law in Brazil is considered an idiot (da Matta 1987: 318). Da Matta thus demonstrates that citizenship is a social role that needs to be learned. He also shows that the role of being a citizen can vary greatly-depending on the kind of specific socialization that formal citizens experience when learning the meaning of this attribute. In the Brazil of the 1980s, as da Matta shows, being a citizen meant very little, and it did not include such things as having basic rights that are protected and enforced by the state. But whereas da Matta uses his analysis to ponder about the penetration of private social relations into the realm of the public, for the purposes of this chapter it is important to retain the basic insight that substantive citizenship is indeed a social role that needs to be validated in order to have concrete consequences for a citizen.

James Holston (2008) has more recently termed this quality of citizenship 
"everyday citizenship." Holston argues that "The quality of . . mundane interaction may in fact be more significant to people's sense of themselves in society than the occasional heroic experience of citizenship like soldiering and demonstrating or the emblematic ones like voting and jury duty. Everyday citizenship entails performances that turn people, however else related, into fellow citizens related by measures specific to citizenship" (Holston 2008: 15).

According to da Matta and Holston, then, democracy is faltering when the concept of citizenship, although theoretically understood and anchored as a core principle in a constitution, has not developed into an everyday practice. Applied to the case of Brazil, this insight highlights the fact that many Brazilians do not know what it means to act as citizens, nor do they know what kind of treatment a citizen can and should expect from other citizens and from the state. In Brazil, as these authors demonstrate, citizenship is but a word. To the rich and privileged, called the "owners of power" by another astute Brazilian social scientist (Raymundo Faoro [1957] 2001), citizenship is a privilege and something the privileged access whenever needed, thus making it their private domain. To them, citizenship is a special right, which requires money and influence in order to give it a practical dimension. As Holston and Caldeira (1998) explain, "The protections and immunities civil rights are intended to ensure as constitutional norms are generally perceived and experienced as privileges of elite social statuses and thus of limited access. They are not, in other words, appreciated as common rights of citizenship" (Holston and Caldeira 1998, in Agüero and Stark 1998: 276).

In order to take advantage of civil rights and liberties, one needs either to have money, or to know the "right" kind of people. All those unable to count on this capital are subject to a system that consistently denies basic civil rights, or at least severely complicates access to them. Corrupt executive branches, and yearlong, often decade-long delays in the judicial system - which is also plagued by innumerable accounts of impunity for the well-off-have undermined the quality of Brazilian citizenship to the point where its dimensions, effectiveness, and reach are not experienced by average citizens and hence not perceived as rights. To the poor, indigenous, black, and excluded, citizenship is but an empty concept, as to them, neither the state nor the majority of citizens respect their autonomy, value their opinions, consider their political preferences, or treat them as equals.

Brazilian elites are not only above the state, they perceive the state and any state-related services as instruments of their whim. Brazilian elites, in other words, have privatized the state and the public realm and use them 
as instruments to control, co-opt, appease, or, if pressured, serve the ordinary people. This service, if it exists at all, is always treated more as a favor than a duty and it is, more often than not, of bad quality. But the Brazilian example is just that: an example introduced here to illustrate the fruitfulness of thinking about, and analyzing, citizenship also as a social role.

However, the effectiveness of being a citizen depends on the recognition of individual autonomy and the possession of inalienable rights by oneself, by others, and by the overarching institutions that exercise power over one's life-first and foremost the state. The implications of this argument are not readily apparent, but they are far reaching. On a very basic level, this argument goes directly against the idea that citizenship rights can be created by decree. No law or legal framework can possibly create effective, that is substantive, citizenship. Equal status under the law, in short, is a necessary but not sufficient condition of effective citizenship. According to Jürgen Habermas, "Only in an egalitarian public of citizens that has emerged from the confines of class and thrown off the millennia-old shackles of social stratification and exploitation can the potential of an unleashed cultural pluralism fully develop" (Habermas 1998: 308). I shall develop other implications of the social dimension of citizenship below, especially when discussing the Colombian and Brazilian cases.

\section{THE DIALECTICS OF CITIZENSHIP}

Thinking about citizenship as a social role and a relational asset already implies adopting a dialectical analytical framework, as it focuses the analyst's gaze away from fixed and static phenomena onto the dynamics and tensions that result between given extremes and ideal types. A dialectical analysis instead focuses on process, negotiation, and tensions. Applying such a perspective alerts us to the fact that citizenship went hand in hand with exclusion from its very conception in democratic Athens. Indeed, it is hardly coincidental that citizenship lost much of its substance as soon as it was applied to a larger group of people. In democratic Athens, we can observe a dialectical relationship between the amount of rights and privileges that citizenship granted and the degree of its exclusivity. As soon as citizenship gained more meaning after the successive reforms by Solon, Cleisthenes, and Ephialtes, Pericles, who succeeded these important democratic reformers, labored to restrict access to citizenship rights. According to Ober, "In $451 / 0$ a new law, advocated by Pericles, limited citizenship to those who 
could demonstrate that they were sons of Athenians on their mother's as well as their father's side. Formerly, sons of non-Athenian mothers had been allowed to become citizens" (Ober 1989: 81). Furthermore, "An attempt in $403 / 2$ to limit franchise to property owners was rejected, as was a proposal to broaden the franchise by granting citizenship to slaves who had helped in the revolution against the Thirty. The Athenians thus reasserted both political equality among citizens and the exclusivity of the citizen body. . . . Allowing slaves to be citizens would deny the linkage between patriotism and citizen blood. Homonoia, 'same-mindedness,' demanded both equality and exclusivity" (Ober 1989: 97f).

This restriction of the citizenry happened in response to important democratic reforms conducted some fifty years earlier-reforms that deepened the rights associated with citizenship. According to Ober, "In 462, an important, if somewhat obscure, series of reforms crippled the direct political power of the elite. A certain Ephialtes led a movement to strip the 'extra powers' from the Areopagus council . . . the Areopagus probably lost some of its legal powers, including the authority to review and set aside as 'unconstitutional' decisions of the Assembly" (Ober 1989: 77). Thus, when elites lost privileges and citizenship gained in importance, it also became more exclusive.

The development of citizenship and its relation to exclusion also becomes very clear in the Roman Republic and during the Empire. According to John Pocock, in Rome, "citizenship has become a legal status, carrying with it rights to certain things_-perhaps possessions, perhaps immunities, perhaps expectations - available in many kinds and degrees, available or unavailable to many kinds of persons for many kinds of reasons" (Pocock, in Beiner 2007: 36). It no longer meant what it had in Athens, where "citizenship is not just a means to being free; it is the way of being free itself" (Pocock, in Beiner 2007: 32). Thus it appears citizenship lost its muscle whenever it was extended to a greater number of people. For Pocock, the legalization of citizenship conducted under the guidance of the Roman lawyer Gaius (C.E. 130-180) was the beginning of possessive individualism and the rise of "homo legalis" - a person whose rights and political power were defined by the amount of assets he commanded. It was also the beginning of stripping citizenship of its aspects of obligation and responsibility. The more citizenship came to solely mean access to rights and entitlements, the more it became subject to the logic of competitive markets, where most assets were worth more if others did not possess them. More than the legalization of citizenship, this transformation meant a gradual commodification of citizenship, and its mutation into a possession and a good that only the rich 
and powerful could afford. In 1981, Pocock wrote: "It begins to look, however, as if the characteristic tendency of jurisprudence was to lower the level of participation and deny the premise that man is by nature political. . . As the polis and res publica declined toward the level of municipality, two things happened: the universe became pervaded by law, the locus of whose sovereignty was extra-civic, and the citizen came to be defined not by his actions and virtues, but by his rights to do things" (Pocock 1981: 359f).

These classical examples amply testify to the fruitfulness of conceptualizing citizenship in terms of relational assets and social roles, especially when considering the nature, reach, and conditions of citizenship in relation to exclusion. Seen from this angle, citizenship and exclusion are indeed intimately connected, or even mutually constitutive, and hence causally entwined.

Modern examples of the dialectical relationship between citizenship and exclusion equally abound. The last European constituencies practicing direct democracy, some Swiss cantons, also controlled the right to be a citizen very closely, in some cases excluding women from being full citizens. Once full suffrage was achieved across all of Switzerland (in 1971), direct democracy started to mean less, and it underwent a similar transitiondescribed by Pocock when discussing the transition from the strong sense of citizenship that prevailed in Athens to the weaker legal notion that characterized Rome. As a result, more and more of the decisions previously made by citizen assemblies are now conducted by specialized agencies, and direct democracy in Switzerland is gradually changing and morphing into a representative system, while those cantons that retain direct rule are among the most exclusionary (Kriesi 2008). Citizenship, it appears, is indeed best thought of as constantly negotiated and heavily embedded in social interactions. As a privilege and an entitlement, it is not equally distributed and not easily socialized.

\section{RACISM AND THE POWER OF WHITENESS}

To add further validity to my proposal of analyzing substantive citizenship through the lens of social roles and asset distributions, I shall focus on another, very pervasive way in which the substantiation of citizenship is denied to some individuals and groups by their fellow first-class citizens, namely, through racism. For many minorities, racism translates into secondclass citizenship, as it undermines trust in public institutions and exposes 
those stigmatized to the discriminatory practices of their fellow citizens. The remainder of this chapter explores some of the ways in which the distinction between first- and second-class citizens is upheld by those benefiting from it. As stated above, I seek to demonstrate that one of the most significant and far-reaching ways to defend first-class citizenship vis-à-vis second-class citizenship is racism.

Accepting the assumption that substantive citizenship is at the same time a social role and a relational asset leads me to the third component of my argument—namely, the importance of racism in conditioning and constraining the effectiveness of citizenship for racialized subjects.

An important dialectical relationship exists between two key aspects of racism-namely, the relationship between the normalization of whiteness, where whiteness functions as a symbolic capital, and the racialization of nonwhites, and their transformation through this process into "others" (Harris 1993; Reiter 2010). Successfully claiming to be white, at least in those societies structured by European colonialism, and under conditions where citizenship finds foremost expression in rights and entitlements, whiteness functions as a symbolic capital that marks one's belonging to the group of the historically privileged-those who have rights and can give favors. It also demarcates the boundary between the privileged and the others-all those who have to depend on favors and protections. The process through which this structuring of social hierarchies works not only separates people into two groups - the "deservingly" privileged and the undeserving rest; it is through this very process that "the rest" become "others." In this process, whiteness is anything but a biological reality, but a negotiated symbolic good and a capital. To those who are able to claim it successfully, it offers important tools with which to uphold and defend privilege. ${ }^{5}$

Michel Foucault has termed this process "normalization," because by applying whiteness as a criterion to structure social space, whiteness becomes the norm and nonwhiteness the exception. Furthermore, through this process, whites become the moral majority and nonwhites minorities and "others" - even in societies where whites actually represent a numerical minority. As whites become the norm, nonwhites become problems and objects of scrutiny, preoccupation, and desire-but they never become equals. Whiteness, to be sure, is not a biological attribute, but a symbolic good that has to be negotiated and validated socially. As such, it works in increments, so that some people are able to claim more of it than others, irrespective of their biological background. In most societies, successful claiming to be white is a matter of financial capital, behavior, language, and dress code, among other things. 
Hence, this process of ordering and hierarchizing social space by using whiteness as a criterion is at the same time one of racialization and normalization. Applied to the case of citizenship in the part of the world colonized by Europeans, claiming to be white is one of the central tools used by historically privileged groups to explain their own privilege and justify their privileged access to rights. It is also the main resource for explaining and justifying the exclusion of all "others." According to Reiter (2010),

Whiteness constitutes capital in addition to the other types of capital, namely financial, social, and cultural. Their importance, however, does not follow a simple additive logic. One type of capital rather connects to the others and together they determine the social place an individual will hold in a society. This allows for some flexibility, as one form of capital can be used to partly compensate for the lack of another, although this flexibility is limited precisely by the lumped condition of the different capitals. In that way, as Bourdieu points out correctly, each single form of capital tends to over-determine the social position of its carrier, as the presence or absence of each single one is perceived as being indicative of the presence or absence of the others. It is in this sense that whiteness over-determines its carrier, bestowing him with a social position that might not be warranted. In other words, because of the composite character of the different forms of capital, whiteness signals the presence of other forms, even though they might not be present. (Reiter 2010: 29)

The result of upholding whiteness as a criterion for privilege and using it as a demarcation to separate first-from second-class citizens is that a formidable barrier to achieving general, substantive citizenship is created. It tends to place nonwhite citizens living in Europe, and the part of the world colonized by Europeans, outside of the realm of effective citizenship. Despite their formal citizenship, they are treated as second-class citizens or even foreigners, as Etienne Balibar (2004) has argued for France, and Reiter (2008) has demonstrated for Portugal. In countries like Brazil, where nonwhites account for over 40 percent of the total population and where blacks predominate in some regions and cities, the same tendency prevails, as Brazilian historian Beatriz Gois Dantas (1988) has convincingly shown. To the white elites of the Americas, nonwhites are not really part of "their" nation; they remain suspicious, foreign, alien, and "others within," in the case of blacks, and a nation apart, or "others outside," in the case of indigenous people. 


\section{CONCLUSION}

Europe's difficulties in integrating non-Europeans, and the trumping of nationalism over citizenship, as well as the related trumping of particularism over universalism, put it in company with other regions and countries of the world that face similar challenges of redefining belonging under conditions of ethnic and cultural diversity, increased transborder migration, and heightened market competition. Europe's difficulty in dealing with "others" thus invites international comparison, which proves helpful to finding new and innovative ways to analyze citizenship. Analysts of Brazilian democracy James Holston and Teresa Caldeira (1998), for example, argue that in Brazil, "the protections and immunities civil rights are intended to ensure as constitutional norms are generally perceived and experienced as privileges of elite social statuses and thus of limited access. They are not, in other words, appreciated as common rights of citizenship" (Holston and Caldeira 1998: 276). Etienne Balibar (2004) reached a similar verdict for Europe in general, and for France in particular. Lessons learned from studying the limits of citizenship in Brazil thus prove helpful to the analysis of French citizenship in particular and European citizenship in general-and vice versa.

At the center of the limitations of citizenship, be it in contemporary Europe, Latin America, or the ancient world, seem exclusive definitions of community. The struggle over privilege always seems to be a struggle over holding "them" out, so that "we" can enjoy our privileges undisturbed. In this very process, who counts as "us" and who as "them" are enacted and reinforced. Once the question of who "they" are is settled, the identity of "us" follows by default. In its modern manifestation, this logic takes the form of nationalism - but before nation-states emerged, the struggle over erecting, justifying, and defending exclusive communities was no less fierce, as I shall demonstrate below.

Hannah Arendt stated wisely that "Of all forms of government and organizations of people, the nation-state is least suited for unlimited growth because the genuine consent at its base cannot be stretched indefinitely, and is only rarely, and with great difficulty, won from conquered peoples" (Arendt 1966: 126). In her analysis of The Origins of Totalitarianism, Arendt further argues that

Conquest, as well as empire building had fallen into disrepute for very good reasons. They had been carried out successfully only by governments which, like the Roman Republic, were based primarily on law, so that conquest could be followed by integration of the most heterogeneous peoples by imposing on 
them a common law. The nation-state, however, based upon a homogeneous population's active consent to its government ("le plebiscite de tous les jours"), lacked such a unifying principle and would, in the case of conquest, have to assimilate rather than to integrate, to enforce consent rather than justice, that is, to degenerate into tyranny. Robespierre was already well aware of this when he exclaimed: "Perissent les colonies si elles nous en coutent Phonneur, la liberte" (Arendt 1966: 125).

Edwige Lefebvre (2003), in turn, argues that "Homogeneity is the precondition for the unity of the pouvoir constituant, and the goal of the constitution is not the organization of the life of the nation, but the establishment of government rules" (Lefebvre 2003: 18). Gary Wilder (2005) proves this argument to be right by demonstrating that the French imperial nation-state was never able, or willing, to expand full and equal citizenship rights to its conquered peoples in the Caribbean. According to Wilder, "Republicanism, bureaucratic authoritarianism, and colonialism were internal elements of an expanded French state that were articulated within an encompassing imperial system" (Wilder 2005: 26). On a similar note, Laurent Dubois (2004) depicts the difficulties that the First Republic encountered in accepting and integrating its former slaves in Guadeloupe. His detailed historical analysis of the years immediately following the French Revolution allows us to witness not only the racist bias of colonial masters, who had much to lose by granting slaves citizenship rights, but also some mainland revolutionaries who sought to uphold culturally biased definitions of the "universal rights of men."

In the Western world, citizenship, it appears, was contested from its very beginning and contrasted with the second-class citizenship of those rendered "others" by nationalist power politics that sought to restrict substantive citizenship rights in order to secure the privileges that European descent could provide. Making former colonial subjects formal citizens without ever including them in the "imagined community" of the nation, and without extending the concrete and substantive rights and entitlements of citizenship to them, thus offered the "perfect solution" to uphold social hierarchies. This move signaled the beginning of white double standards and guilt, as well as black double-consciousness and indigenous apartheid. This diagnosis also casts a deep shadow over the reach and depth of the modern principles of universal rights advocated by the French Revolution, as fraternité appears to have had a restrictive meaning from its very beginning. Beginning with the French revolutionaries, European colonizers and their descendants did not imagine nonwhites to truly be brothers. The 
genealogy of these dialectics of exclusion can be traced back all the way to the beginning of citizenship in classical Athens.

In this book, I thus propose to examine the quality and substantiveness of citizenship and democracy by analyzing it through the lens of citizenship and second-class citizenship, rights and duties, inclusion and exclusion, belonging and remaining an outsider, being a national and a foreigner. Instead of arguing that reality is indeed structured by these dualisms, I propose to only use these categories and words as lenses, or angles, that allow us to analyze reality in innovative and fruitful ways. This endeavor is the more fruitful the more this angle is able to capture the dynamics that bind the above dualisms together, and the more it is able to focus the analysis on the mutually constitutive dimensions of these analytical pairs. Reality, to be sure, is not structured around dualisms. It is complex, heavily interdependent, and contingent along a multiplicity of factors. Nothing can be said that "truly" captures reality, be it the reality of citizenship or any other. However, by proposing to analyze the reality of citizenship by focusing on its everyday dimensions, its substantiveness, its relational character, and its social embeddedness, I propose a theory-driven and hence simplifying angle that puts this segment of reality into a certain order, thus allowing it to make sense. Any order, as Immanuel Kant knew, springs out of our own minds and is not inherent to nature, let alone to social reality. The worst way to deal with this potentially disturbing fact is to ignore it and pretend that our understanding of reality is direct and unmediated, neutral, objective, and not influenced by our own situatedness. Second worst is to argue that reality is indeed structured by the categories and theories we use to explain it. Doing so means falling prey to reification and risking the analysis of oneself while claiming to analyze the world.

Equipped with the ontological, epistemological, conceptual, and methodological tools elaborated in chapters 1 and 2, I should be able to steer free from all the potential pitfalls already discussed, and I am now ready to apply the analytical tools and insights I have created to empirical reality. In what follows, I will thus apply this analytical apparatus to several cases in order to illustrate their usefulness and fruitfulness for producing insight and understanding about the workings and conditionalities of effective citizenship. As explained above, the cases presented here do not serve the purpose of testing my hypotheses. They are also not selected according to a traditional case-study rationale. Instead, each case serves the purpose of highlighting one central theme, or facet, of how citizenship is lived and experienced by different peoples at different times and under different circumstances. If similarities and patterns emerge-and I hope to be able to 
demonstrate that they do-then these regularities are more an unveiling of the human condition when living in society, or otherwise organized in groups, than they are an unveiling of regularities, or even laws, of nature or behavior. In essence, each case study focuses on one particular way in which citizenship is lived, experienced, performed, and implicated by other factors external to it, so that by the end, the reader should have gained a relatively complex and well-rounded picture of the different realities hiding behind the term "citizenship." After reading this book, he or she should also be in a position to formulate specific questions about citizenship regimes in different places and at different times. 


\section{Classical Citizenship The Political and the Social}

In a quarter century, Greek self-knowledge passed from the idea of a divine anthropogony to the idea of man's self-creation. The stasimon from Antigone and, with it, consubstantially and unsurpassably, Thucydides' Funeral Oration, which comes twelve years later, give this self-knowledge its most striking forms.

-CORNELIUS CASTORIADIS, 1991

This CHAPTER FOCUSES ON ClASSICAL CITIZENSHIP AS PRACTICED and experienced in Athens and the Roman Republic. To do so, for a political scientist, is to venture onto thin ice, as I have to rely almost entirely on secondary sources and a few translated primary sources. The chapter is, however, a necessary part of this book, as it allows me to add a historical dimension to the problem of democracy, citizenship, and exclusion. Exclusion from citizenship, as well as the establishment of second-class citizenship as a contrast to full, or first-class citizenship, is not new, as this chapter will show. It reaches back to the very beginnings of democracy —at least to those democracies of which we have records. ${ }^{1}$

A thorough critique of the Western democratic tradition and the ideas associated with it, such as liberalism and republicanism, the way I intend to conduct it here, would be incomplete without an analysis of classical Athens and Rome. By including these cases, as well as the chapter to follow about citizenship in medieval city republics, I also seek to provide a genealogy of citizenship. If exclusivity and discrimination were indeed 
integral parts of every historical example of citizenship we know of, as I seek to demonstrate, then it is safe to say that citizenship and exclusion are indeed mutually constitutive of each other to the point where one has never existed, and in all likelihood cannot exist, without the other.

This chapter, then, focuses on Athenian citizenship when it first emerged, in 594 B.C.E., with the reforms instituted by Solon. It develops several themes: first, what democracy and citizenship meant to Athenians; second, whom it excluded and how; third, how societal inequality was dealt with in Athens; and fourth, what happened to Athenian democracy once it was absorbed by Rome.

The analysis of the Roman Republic is crucial to one of the central arguments of the whole book, namely, the commodification of citizenship, which started, according to John Pocock (1995) as early as the second century C.E., when the Roman lawyer Gaius started to codify Roman law, thus changing the character of citizenship from political to legal. The second part of this chapter will thus focus on the Roman Republic and the relationship between a codification of laws and the resultant depoliticization of democracy.

\section{DEMOCRACY AND CITIZENSHIP IN ATHENS}

The descriptions of ancient Greek democracy by Aristotle, Plato, Xenophon, Herodotus, Polybius, and Pericles, and the many modern and contemporary scholars who have made ancient Greece their field of study, allow us to reconstruct how democracy was practiced in Athens and surrounding Attica between 507 B.C.E., when Cleisthenes reformed Athenian governmental institutions in such a way as to avoid the concentration of power among the elites, and 338 в.C.E., when Athens came under the control of Philip II of Macedon, after the battle of Chaeronea, and joined the League of Corinth in 337 B.C.E., effectively ending its independence.

The ancient Greek polis sought to nurture its members' sense of moral responsibility towards the collective. Accordingly, the chief benefit of living in a polis was justice and moral improvement, as, according to Aristotle, the polis "enunciates what is just, thereby allowing man's best qualities to flourish" (Manville 1997: 45).

Aristotle explains in his Politics: "To be fellow citizens is to be sharers in one polis, and to have one polis is to have one place of residence" (Pol. 1260b40-1261a1) According to Aristotle, the citizen of the polis is one "who 
enjoys the right of sharing in deliberative or judicial office" (Pol. 1275b1820). Thus, according to the words of one analyst, Athenian citizens were not taxpayers, but shareholders in a corporation whose profits were moral excellence (Manville 1997: 45).

To be a full Athenian citizen thus did not mean to have influence in the doings of the state, but rather to be part of the state. Athenian democracy provides not only the strongest example of direct democracy, but also an example of a political system where ruling and being ruled overlapped considerably. The core of Athenian democracy consisted of not separating rulers from ruled. Indeed, Athenian citizens all participated in the ruling of their polity. To ensure that this setup remained in place, Athenian statesmen devised several means, such as appointment to office by lot. In addition, several institutions were created for the purpose of avoiding a concentration of power among state officials. The strong commitment to avoiding a system where something like a political ruling class emerged becomes evident from many of the formulations Aristotle uses to describe Athenian democracy; for example, when he explains that since some people are not superior to others, "it is clear that, for a variety of reasons, all must share alike in the business of ruling and being ruled by turns" (Aristotle, Pol. 1332b12, 1992: 432).

\section{THE CHARACTER OF ATHENIAN CITIZENSHIP}

According to Manville (1997), "Citizenship was membership in the Athenian polis, with all that this implied-legal status, but also the more intangible aspects of the life of the citizen that related to his status. It was simultaneously a complement of formal obligations and privileges, and the behavior, feelings, and communal attitudes attendant upon them" (Manville 1997: 7).

In fact, Athenian full citizens had plenty of rights and even more obligations. Once they reached legal adulthood, all young Athenian male citizens were expected to serve in the military. Citizens also were entitled to participate in public cults, festivals, and religious worship. They had the right to attend, speak, and vote in the popular assembly (ekklesia). They could serve (after the age of thirty) as a juror in the law courts (dikasteria). Very importantly, depending on age and eligibility, they could exercise elected and allotted offices (archai). They were entitled to redress and receive protection from the laws. They were allowed to own land in Attica. Finally, they 
were entitled to receive public disbursements for services provided (Manville 1997: 9).

Thus, Athenian citizenship consisted of a set of rights and obligations and duties towards the collective. It was not a set of legal entitlements only, but rather a political system of breaking down the barriers between ruling and being ruled as much as possible. For Ostwald, "the Greeks tended to see citizenship more in the context of sharing and being part of a community on which the individual depends for his or her sense of identity" (Ostwald 1996: 49). In Athens, citizens ruled themselves. According to Josiah Ober, "For the first time in the recorded history of a complex society, all native freeborn males, irrespective of their ability, family connections, or wealth, were political equals, with equal rights to debate and to determine state policy" (Ober 1989: 7).

To clarify: Classical citizenship, rather than a right, instead focused on responsibilities and duties. In his famous speech, Pericles emphasizes the duties and responsibilities of Athenian citizenship when he states, "For we alone regard the man who takes no part in such things not as one who minds his own business (apragmona), but as one who has no business here at all (achreion). (2.40.2)" (quoted in Manville 1997: 15).

Athenian citizenship thus meant a lot to all those who were citizens. It made them power holders and rulers of their own destinies. How could such a system be achieved and sustained? The successive reforms conducted under Solon, Cleisthenes, and Ephialtes provided the institutional framework that made Athenian democracy possible.

SOLON, CLEISTHENES, AND EPHIALTES:

COUNTERBALANCING SOCIETAL INEQUALITIES THROUGH POLITICAL INSTITUTIONS

Aristotle says of Solon (c. 638 в.C.E. -558 в.C.E.): "By setting up courts drawn from the entire body of citizens, he did establish democracy in Athens" (Aristotle 1992: 161). For Aristotle, popular participation in the courts (dikasteria) was the core element where popular sovereignty ultimately rested. Martin Ostwald, the renowned scholar of ancient Greece, agrees, arguing that "Solon established popular power by opening membership in the law courts to all" (Ostwald 1986: 5). Ostwald further explains that "From pre-Solonian times on, there were in Athens two kinds of law courts. Most private litigation fell within the jurisdiction of one of the nine archons, each 
in charge of his own tribunal and each within a well-defined sphere of competence, authorized to judge lawsuits in their own fight, and not, as they do nowadays, merely to conduct the preliminary inquiry" (Aristotle, Ath.Pol. 3.5). Other cases regarded as private were tried before the Areopagus - that is, the council of ex-archons with considerable power across several jurisdictions, which had, at all times in Athenian history, jurisdiction in all cases of homicide, of wounding or poisoning with intent to kill, of arson, and such religious matters as the care of the sacred olive trees (Ostwald 1986: 6f; also Sealey 1964: 12).

Aristotle credits Solon for the introduction of the procedure of eisangelia and explains, "A characteristic feature of eisangelia in classical times was that it could be initiated by any citizen, usually before the Council but on occasion also in the Assembly (Aristotle, Ath.Pol. 43.4)" (Ostwald 1986: 9). Most specialists agree that the core of the Solonian reforms consisted of three measures. First, the prohibition against giving loans on the security of the person of the debtor, thus providing important safeguards against losing one's freedom, and thus establishing very basic rights of unalienable personhood for Athenian citizens; second, the right to take legal action on behalf of an injured party, independent from one's social standing; and third, the institution of an appeals procedure (ephesis) and a new court (the heliaia) to hear appeals, which provided a check against the arbitrary administration of justice on the part of the aristocratic establishment and made the people the court of last resort (Ostwald 1986: 14f).

Democratic reform in Athens was advanced even further by Cleisthenes (c. 570-507 B.C.E.). Cleisthenes's reforms were mentioned by the historian Herodotus, who credits him with the true establishment of Athenian democracy. The central question that Cleisthenes addressed was how to prevent societal inequalities from spilling over into the public realm. In contrast with modern reform proposals that target societal inequalities and seek to achieve equitable political influence by equalizing society, Cleisthenes took societal inequalities for granted and instead sought to devise ways to diminish their importance in the political realm. The main way Cleisthenes pursued this goal was by breaking ethnic loyalties and replacing them with civic ones. This was achieved, in the main, by dividing Attica into three regions - city, coast, and inland-and then creating small administrative units, called demes. Above the demes, Cleisthenes created thirty trittyes and above those, ten phylai. Each phylus (tribe) contained three trittyes, one trittye from each of the three regions (Jones 1999: 155). The system that emerged from the Cleisthenic reforms is depicted in the figure. 


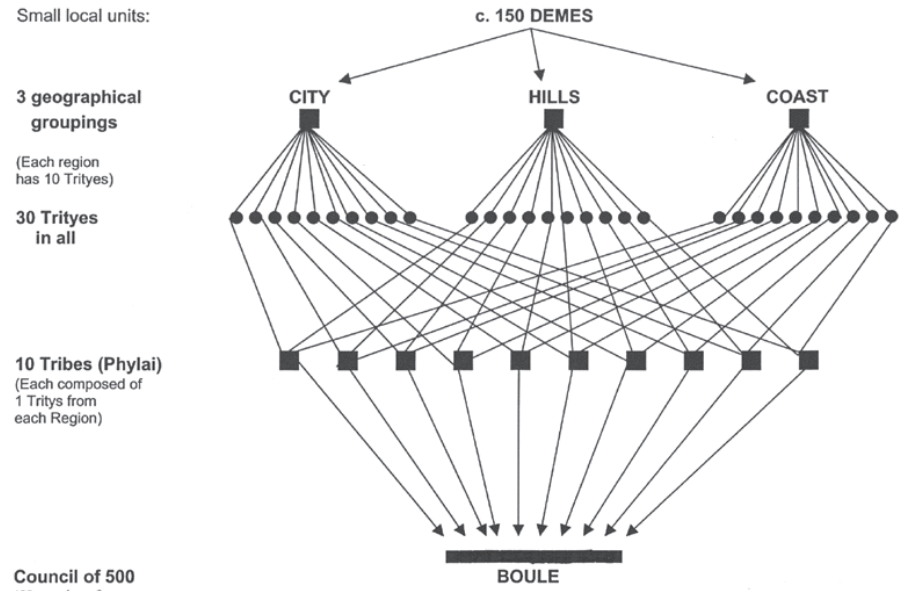

DIAGRAM OF KLEISTHENES' POLITICAL ORGANISATION

Source: University of Oregon.

This institutional design provided a way to neutralize the political influence of dynastic clans, family factions, and regional loyalty by diluting them and forcing different regional groups (pedieis, the faction of the plains; paralioi, the faction of the coast; and hyperakrioi, the faction of the hills [Ellis and Stanton 1968: 98]) together into new associations. Furthermore, Cleisthenes created six new trittyes, that is, regional associations, amplifying them from the previous four and populating those new trittyes with demes from different regions, with different social and economic standing. This is the mixed form of government that Aristotle talks about in his treatise on politics (Ostwald 1986: 19).

However, according to Ostwald, even after Cleisthenes's reforms, the Athenian upper class still controlled several important political institutions, thus giving it supremacy and control over the ordinary citizens. Particularly, the treasurers still had to be members of the highest property class, and the nine archons, or governors, of the highest two. Furthermore, the Aeropagus, that is, the high court of appeal for both criminal and civil cases, was still dominated by societal elites (Ostwald 1986: 26f).

However, Cleisthenes also sought to weaken the power and influence of the Aeropagus by shifting authority of certain cases over to the lesser, less elite-dominated court of the heliaia (Ostwald 1986: 28). Considered as a whole, the Cleisthenian reforms created the basis for political equality among citizens through enforcing, institutionally, the principles of political equality, or isonomia (Ober 1989: 70). 
The final measures towards establishing true political equality among citizens are associated with the third of the Athenian reformers, Ephialtes. Ostwald explains, "Just as political isonomia implied that no legislative measure could be valid without the approval of the Assembly, so a judicial isonomia was introduced, either by Cleisthenes himself or soon after his reforms, in crimes against the state, in which the verdict of the people as a whole acted as a counterweight to what had been the sole jurisdiction by a body composed of the rich and well born. Ephialtes' achievement was to complete the process by giving the people full sovereignty in handling crimes against the state" (Ostwald 1986: 39f).

According to Ober, "In 462, an important, if somewhat obscure, series of reforms crippled the direct political power of the elite. A certain Ephialtes led a movement to strip the 'extra powers' from the Areopagus council . . . the Areopagus probably lost some of its legal powers, including the authority to review and set aside as 'unconstitutional' decisions of the Assembly" (Ober 1989: 77; also Rihil 1995). ${ }^{2}$ Ostwald provides some more detail on the reforms introduced by Ephialtes. He explains that

The transfer of judicial powers in political cases from an aristocratic body, the Areopagus, to the Council of the Five Hundred, in which every deme of Attica was represented, to the Assembly, of which every adult male citizen was a member, and eventually to the jury courts, on which every adult male was eligible to serve, did not, to be sure, place executive power into the hands of the demos. The highest offices in the state remained the preserve of the higher property classes, and even the opening of the archonship to the zeugitai as of $457 / 6$ в.с. (Aristotle, Ath.Pol. 26.2), which was a further step toward a more complete democracy meant only that this office no longer ranked as a major magistracy. Still, by transferring jurisdiction in political cases from the Areopagus to popular organs, Ephialtes gave the demos an effective control over the executive offices that is tantamount to guardianship over the state; by extending to judicial proceedings the isonomia that Cleisthenes had given the people in legislative matters, he created popular sovereignty, which was justly called demokratia. (Ostwald 1986: 49)

Each deme annually sent a fixed number (based upon its population) of individuals to serve on the new advisory Council of 500, which replaced the Solonian Council of 400, and by doing so, the elite lost its veto power over the decisions of the masses (Ober 1989: 78). In this Council of 500, every Athenian citizen had the right to speak, called isegoria, thus making it the basis of popular sovereignty. 
After 462, Athenian democracy saw a lowering of property qualifications for office holding, as well as the introduction of pay for government service (Ober 1989: 79). In 457 all offices, including the archonships, were opened to the zeugitai, that is, manual workers (Ober 1989: 80). This movement away from property qualification was indeed gradually expanding during the fifth century B.C.E., so that by the fourth century there were no more property qualifications for office holding, and even thetes, that is, landless peasants and agricultural laborers, could hold public office-and in fact many did (Ober 1989: 80).

In sum, Athenian citizens learned, through practical political participation, how to rule themselves and their polity, leading Ober to the conclusion that "At Athens the masses ruled, and the decisions of the majority were binding upon the minority . . . the absence of property qualifications for the exercise of citizenship rights was a basic principle of the Athenian political order. Pay for office holding and for political participation, selection of magistrates by lot, and the right of free speech in the Assembly_all of which were guaranteed by the binding nature of mass decisions upon the entire populace-made domination of the state's political apparatus by rich citizens more difficult" (Ober 1989: 193).

However, given that Athenian citizenship bestowed so many rights and duties on every citizen, it is not surprising that Athenian citizenship was highly circumscribed and exclusive. Furthermore, the more rights and duties became associated with Athenian citizenship, the more restrictive it became. The relationship between the depth of citizen rights and responsibilities and its exclusivity deserves some further inquiry.

\section{DIFFERENTIATED VOTING RIGHTS AND XENOPHOBIA UNDER PERICLES}

Max Weber (1968) provides a rather skeptical assessment of the degree to which average poor citizens were able to wrest power away from the hands of the rich and aristocratic. According to Weber, in Athens, "the political equality of the free-born citizenry was vitiated by the gradation of voting rights and office eligibility, originally in terms of ground rents and armed service capabilities and later according to wealth" (Weber 1968: 1311). Indeed, in Athens, the right to be elected into certain offices was restricted, first by descent and later by wealth, and then again, during the time of Pericles, by descent, which is commonly attributed to the increased influx 
of foreigners (xenoi) into Attica-some of whom would be eligible for office if wealth had remained the criterion to regulate active citizenship. ${ }^{3}$

In the years 450-451, Athens introduced payment for judicial officeholders, as well as for all those serving in the boule, thus making it possible for the poor, and all those dependent on their daily income, to take time off in order to attend to issues of public interest. However, this measure to popularize political participation and office holding was counterbalanced by measures aimed at restricting the definition of who counted as a citizen.

A typical dialectical tradeoff was set in motion, one that would make reappearances throughout the history of democratic rule and, as a consequence, appears in several chapters of this book. When citizenship is valuable to those who have it, they will seek ways to restrict access to it. The asset character of citizenship becomes clear in all these maneuverings. When citizenship means little and promises few tangible benefits, access is relatively open. When, however, citizenship is invested with more rights, privileges, and entitlements, those who have it tend to seek to limit the number of people with whom they wish to share the benefits. Athens is but one example of many-but it is certainly the oldest one on record.

During the time when Pericles (495-429 в.С.Е.) was exercising much influence on Athenian politics, in the 450s, citizenship was restricted to those who descended from both an Athenian father and mother-whereas before that time, having an Athenian father was sufficient. As John Thorley (1996) points out, during the time of Pericles "the advantage of being an Athenian citizen and the feeling of power it gave were very real" (Thorley 1996: 66). Thorley is referring to the export and import taxes paid to Athens at the harbor of Piraeus. Furthermore, Pericles's time was one of expansion and establishment of colonies in Italy and Thrace, and hence the appearance of colonial subjects. Under such circumstances, Athenian citizens moved to secure their privileges by shielding them against foreigners (xenoi) and what today are termed legal resident aliens, metics (metoikoi).

By classifying and separating political rights from civic responsibilities, and reserving rights to some while demanding responsibilities from others, Athens also gave birth to a regime of differentiated first- and second-class citizenship. 
Even after the reforms of Solon, Cleisthenes, and Ephialtes, Athenian citizenship remained heavily circumscribed. Aristotle argued that "The citizen must not live a mechanical or commercial life. Such a life is not noble, and it militates against virtue. Nor must those who are to be citizens be agricultural workers, for they must have leisure to develop their virtue, and for the activities of a citizen" (Aristotle, Pol. 1328b24, 1992: 415). For Aristotle, women, slaves, foreign residents, visitors, and manual workers (banausoi) did not deserve full citizenship rights. Banausoi could participate in assemblies, but they were not allowed to hold office. Explains Aristotle: "But the best state will not make the mechanic a citizen. But even if he is to be a citizen, then at any rate what we have called the virtue of a citizen cannot be ascribed to everyone, not yet to free men alone, but simply to those who are in fact relieved of necessary tasks" (Aristotle, Pol. 1277b33, 1992: 184).

Indeed, after 450, Athenian citizenship was restricted to those of double Athenian descent, while women, slaves, and resident aliens-the majority of the total adult population-remained excluded from participation in political life (Ober 1989: 5). According to Ober, "In 451/0 a new law, advocated by Pericles, limited citizenship to those who could demonstrate that they were sons of Athenians on their mother's as well as their father's side. Formerly, sons of non-Athenian mothers had been allowed to become citizens. The immediate concern prompting the reform may have been the tendency of Athenian clerouchs [that is, Athenian citizens residing in one of the colonies] . . . to marry foreign women while abroad" (Ober 1989: 81; also Walters 1983: 332).

As mentioned above, it was indeed after the reforms of Solon, Cleisthenes, and Ephialtes that foreigners (xenoi) and resident aliens (metoikoi) saw their citizenship rights further curtailed, or eliminated altogether. ${ }^{4}$ This limiting of citizenship happened precisely at a time of increased foreign presence in Athens. Explains Ober (1989), "An attempt in 403/2 to limit franchise to property owners was rejected, as was a proposal to broaden the franchise by granting citizenship to slaves who had helped in the revolution against the Thirty. The Athenians thus reasserted both political equality among citizens and the exclusivity of the citizen body. . . . Allowing slaves to be citizens would deny the linkage between patriotism and citizen blood. Homonoia, 'same-mindedness,' demanded both equality and exclusivity" (Ober 1989: 97f).

According to Peter J. Rhodes (2004), in the Athenian polis of the fifth 
and fourth centuries B.c., "making a decision was entrusted to the citizens directly, in an ekklesia, assembly, open to all citizens (some kinds of business required a quorum of 6,000 , perhaps 10 percent of the citizens before the Peloponnesian War of 431-404 and 20 percent after), guided, but not seriously limited by the boule, council, numbering 500, a representative body whose membership changed each year" (Rhodes 2004: 3). Rhodes also explains that "There was no property qualification for the enjoyment of political rights (but even Athens had a qualification for office holding, still enforced in the 5th century but not in the fourth, when the number of citizens was lower), and the stipends made it easier for the poorer citizens to exercise their rights; and the assembly was not dominated by authorities but was a powerful body and one in which all the citizens could play an active part" (Rhodes 2004: 4).

After Athens had lost the Peloponnesian War in 413 в.C.E., which brought economic hardship to Athens and stripped it of its regional supremacy, Athenian citizenship became even more restrictive. In the 370 s, the law regulating citizenship was as follows:

If an alien shall live as husband with an Athenian woman in any way or manner whatsoever, he may be indicted before the Thesmothetae by anyone who chooses to do so from among the Athenians having the right to bring charges. And if he be convicted, he shall be sold, himself and his property, and the third part shall belong to the one securing his conviction. The same principle shall hold also if an alien woman shall live as wife with an Athenian, and the Athenian who lives as husband with the alien woman so convicted shall be fined one thousand drachmae. (Demosthenes 59.16)

This new, more restrictive regulating of access to the benefits of Athenian citizenship gives further evidence of the apparently inherent tradeoff between the quality of citizenship rights and the inclusiveness of such a regime.

\section{LESSONS FROM ATHENS}

The most important lesson from Athens is that Athenian citizens established "the political" as a central part of citizen life. Politics, government, governance, and the state were all integral to Athenian citizens' everyday lives. There was no alienation from politics or from the state, because the citizens literally were the state. For Aristotle, humans thus were political 
animals by nature and vocation. "Politics" in such a world was not a separate reality, conducted and controlled by a special group of people, and neither was the act of lawmaking. To the contrary, making the laws that govern the community was at the heart of this model, highlighting its strong commitment to self-rule and autonomy. This is the time and place that triggered Protagoras to say that "Man is the measure of all things." It was also the time of Sophocles, who wrote Antigone in 442-43 в.C.E. and, according to Castoriadis (1991), his anthropology "presupposes nothing: there, men create these capacities and possibilities themselves; simply, clearly, and insistently, it posits humanity as self-creation. Men have taken nothing from the gods, and no god has given them anything whatsoever. That is the spirit of the fifth century, and it is to this tragedy that the Athenians gave the laurel wreath" (Castoriadis 1991: 22ff).

An exploration of the Athenian case under the analytical angle of citizenship as a social role and a positional good, as well as from the perspective of autonomy, allows us to see that Athenian citizens indeed planted the seed for self-rule, and also found a way to counteract the economic and social inequalities that divided them to establish political equality-particularly with the reforms of Ephialtes. The most defining element of ancient Greek democracy was precisely the lack of distinction between ruler and ruled. The citizens were the state and the government. Citizenship, although highly circumscribed and restricted, meant falling under the rule of law and making those laws at the same time. No passive sense of citizenship existed. This is what sets Athenian democracy aside from most, if not all, democratic models to follow.

Athenians ruled themselves, and they found ways to organize and preserve this self-rule against the ever-present threats posed by aristocrats, oligarchs, and by sheer numbers. Over 30,000 Athenian citizens were effectively able to practice self-rule in a time when means of transportation and communication were precarious, if measured against contemporary possibilities. Despite strong social, cultural, economic, and educational differences among citizens, they devised a system where many of them had to be involved in running public affairs. On top of the institutional design, which broke up regional and tribal ties into boules and required a very active and frequent presence in public meetings, discussions, and decision making, the Greeks also shunned those who did retreat into private life.

However, the Athenian case also points at the conditionalities for establishing such a form of self-rule, and we can see that from its very invention, citizenship was highly exclusive, circumscribed, and disputed. Even in this early example of democratic rule, we are able to detect the struggles over 
popular access to the different branches of government. Only some 10 to 20 percent of the population living in Attica during the time of Athenian democracy were citizens, thus highlighting its exclusiveness.

It appears that the division between those with rights and those with duties was born with democratic citizenship, and analyzing Athenian citizenship as an asset thus provides some insight into its dynamics and the ways in which it was lived and experienced. As John Davies (2004) points out, Athenian citizens were not merely a descent group, but also an interest group, because being an Athenian citizen came with very tangible privileges. Davies hints at the relationship between the value of citizenship and its exclusiveness when he states, "Citizenship was a valuable privilege, both economically and politically, and became more so as Athens's power grew in the fifth century and as the prerequisites of citizenship became more valuable, more frequent, and more pervasive: to open citizenship to all who wanted it would devalue it unacceptably" (Davies 2004: 25). ${ }^{5}$

The Athenian case thus sets the stage for a drama that unfolds at different stages of human history. We do not know exactly how much of the knowledge about Athens influenced subsequent acts-but that is not important for the purpose of this book. Similar to the Athenian case, each of the cases discussed in this book allows us to see and discuss another aspect of democratic citizenship and the limits to the struggle over self-rule, allowing us to assemble a puzzle where every piece is different and tells a different story; but together they provide a detailed picture of the conditions, limits, and inherent contradictions of citizenship.

The strong connection between making rules and living under them indeed started to wither once the Athenian model was transplanted to Rome. The Roman Republic (509-27 B.C.E.) already represented a form of governance that lacked what was at the heart of the Athenian system, namely, the element of direct citizen rule. Representation came to replace the principle of direct self-rule, and it was this already modified version of democracy that became the Western democratic model par excellence. This being the case, a deeper look at democracy as practiced under the Roman Republic is warranted.

THE ROMAN REPUBLIC

From its very inception, the Roman variety of democracy differed significantly from the Athenian model. Representation combined with pronounced 
societal inequalities, and no institutions to block the spilling over of these inequalities into the public and political realms, produced a system where some ruled and others, the majority, were ruled and had no active saying in the making of the rules and laws by which they had to live.

Well before the beginnings of the Republic, commonly dated at 509 в.C.E., Roman society was divided into patricians and plebeians. Adcock (1969) explains that "The patrician body . . . was united in tradition and social consciousness; small as it was, by its military and landowning character and its clientele it went far to justify the position of privilege which it enjoyed" (Adcock 1969: 20).

The change from the rule of the people to elite rule through representation and with elections was, however, not a necessary development, as I shall argue here, and not precipitated by increased numbers. Rather it was a development actively advanced by those who had much to gain from it: Roman elites, especially those represented in the senate.

The Roman Republic was established when the early monarchy was terminated in 509 в.C.E., and it lasted until the year 27 в.C.E., when Octavian was named Augustus and became emperor. Under the Roman Republic, sovereignty rested with SPQR, "Senatus Populusque Romanus"-the senate and people of Rome (Shotter 1994: 4). However, the people of Rome were highly stratified and divided into several property classes (Vanderbroeck 1987: 18). According to specialist Paul Vanderbroeck, "At the bottom of society were the (male) free citizens, who had the right to vote and who participated in the popular assemblies. Among this group large differences could exist. . . . A special phenomenon of Roman society was that freed slaves were enfranchised. The relationship between members of the upper strata and the lower strata is mostly to be qualified as a patron-client relation. Vertical ties permeated all status groups and existed in multifarious forms" (Vanderbroeck 1987: 20).

Rome had two types of popular assemblies. The Centuriate Assembly was divided into five property classes, which were subdivided into 193 centuries. The Comitia Centuriata decided on war and peace and elected the highest magistrates. The Comitia Tribute, in turn, decided on most legislation, elected the lower magistrates and the tribunes of the plebs, and in jurisdiction could serve as a court of appeal. The tribal assembly was divided into thirty-five tribes (residential districts), four for the city and thirty-one for the countryside. The number of citizens in a century varied. The highest census class had seventy centuries, while the unpropertied citizens were packed into one century and therefore only had one vote in the Centuriate Assembly (Vanderbroeck 1987: 17f). The Social Wars of 90-87 в.C.E. 
between Rome and its Italian allies (the socii) were resolved largely by Rome's extending citizenship to all those south of the river Po in 90 B.C.E. A census conducted in the year 70 B.C.E. indicates that by then, Roman citizenry had reached the number of 910,000 (Millar 1998: 28).

Roman citizenship was thus split into two groups-patricians and plebeians. Plebeians had access to sovereignty and could be elected to the senate, but political office was not remunerated, which made it practically impossible for average plebeians to serve. Popular sovereignty rested in the assemblies-three comitia and the Concilium Plebis. However, according to Shotter, "There was neither freedom of debate nor power of initiating business from the floor. The people's function, in other words, was limited to that of voting" (Shotter 1994: 5).

The senate, dominated by the rich, exercised broad clientelistic power over the common people, and "senatorial endorsement (senatus consultum) was considered a necessary prerequisite to the exercise of popular sovereignty" (Shotter 1994: 5). Plebeian citizens had the right to protest senate decisions (provocatio) and they could elect their own tribal leaders, called tribunes. In the Concilium Plebis, binding decisions could be made that became law once the two consuls, elected from within the senate, agreed. However, in the third century B.c. the decisions of the plebeian assembly were given the independent force of law (Shotter 1994: 7). This strengthening of popular sovereignty has led one of the foremost scholars of Republican Rome, Fergus Millar (1998), to conclude that "The populus Romanus was not a biological descent group, but a political community defined by rights and duties (the latter consisting predominantly of military service in the legions), and it was formed above all by the progressive extension of Roman citizenship throughout Italy, and by the distinctive Roman custom of giving citizenship to freed slaves. Participation as a citizen was not limited by considerations of wealth or class (though the holding of elective office certainly was), but it will have been far more profoundly affected by distance. The unaltered convention that the citizen could exercise his rights only in person, by voting in the Forum or the Campus Martius, gave an overwhelming predominance in the politics of the late Republic to those 'representatives' of the wider populus Romanus who lived in and around the city" (Millar 1998: 211).

During the early republic, when Rome still had no standing army, Roman citizens had the following rights: "In 197 в.C., the 'right to appeal' was extended to the citizen on campaign, thus freeing him from his commander's ultimate sanction of summary execution. Second, by a law of 177 B.C., Roman citizens were given a greater proportion of war booty" (Shotter 
1994: 11). Overall, however, the scale of participation in the Roman Republic remained very limited. According to Henrik Mouritsen (2001), only a few percent could actually attend the meetings and assemblies, and often the level of attendance was much lower. As a result, a large majority of the population never took part in the political process. For Mouritsen, "The Roman system was, in other words, based on the few rather than the many" (Mouritsen 2001: 128). The same author finds that the cause for this shortcoming was not distance itself, but rather "the particular position of the influence which the system reserved for the elite. The mere existence of a permanent body of nobles, who monopolized all political initiative, experience and authority in the Roman state, would inevitably have threatened the powers held by the comitia" (Mouritsen 2001: 129).

Thus, whereas the Athenian polis categorically excluded women, slaves, and foreigners from being active citizens, during the Roman Republic property was the main, even if not the only, criterion for exclusion from the political community. Furthermore, it was also during the Roman Republic that the principle of electing representatives to decide for oneself became the dominant practice of democratic rule. According to Frank Adcock (1969), "In terms of political power the closed body of patricians became as it were a state within a state, with special rights protected by custom if not conferred by statute, and no doubt a strong corporate sense" (Adcock 1969: 22).

Plebeians, however, had legislative authority in their conciliums, and the tribunes elected from these had significant power. They could veto laws, elections, and the actions of other magistrates they felt were against the interests of the plebs. In the middle of the fifth century, Rome passed a legal code that added protection to plebeians. The very same legal code that protected them by establishing the rule of law also institutionalized the division of society by outlawing marriages between patricians and nonpatriciansalthough this prohibition was revoked a few years after its passing into law. Nevertheless, the mere attempt to institutionalize status difference points to the importance of this societal division in Rome.

THE WATERING DOWN OF CITIZENSHIP:

FROM RESPONSIBILITIES TO RIGHTS

John Pocock (1995) asks whether exclusion from full citizenship rights are "accidental or in some way essential to the ideal of citizenship itself" (Pocock 1995: 31). He finds in the redefinition of citizenship under Gaius 
(130-180 C.E.) the deciding moment where the character of citizenship shifted from being a political concept, as inherited from Aristotle, to a legal concept. For Pocock: "the origins of possessive individualism" (Pocock 1995: 35). Pocock explains that in Rome, "Citizenship has become a legal status, carrying with it rights to certain things-perhaps possessions, perhaps immunities, perhaps expectations - available in many kinds and degrees, available or unavailable to many kinds of persons for many kinds of reasons" (Pocock 1995: 36). Once citizenship was defined in terms of legal rights and the protection of one's property, political rights were transformed from the right to decide one's destiny and the destiny of the community in which one lived, to the right to elect representatives, who from now on decided for the community.

According to Peter Brunt (1971), "In democratic Athens, the ordinary citizens met frequently in popular assemblies open to all, which decided every question of policy and closely supervised the executive officials; each citizen counted for one and not more than one. Rome, too, had popular assemblies, though they were not based, like the Athenian, on the principle of equality. ... Only at the very end of the Republic was provision made for 70,000 to vote together, about 6 percent of the total citizen body" (Brunt 1971: 8). Brunt further argues that "The Romans themselves contrasted favorably their liberality in granting citizenship with the exclusiveness of Athens. It is perfectly true that their liberality gradually did much to win the loyalty of subjects first in Italy and later, from Caesar's time, in the provinces. This policy could only have succeeded because the Roman system was undemocratic" (Brunt 1971: 9).

In other words, had Roman citizenship meant more and provided more rights and entitlements, access would have been far more restrictive. Although sovereignty ultimately belonged to the people-as the people elected magistrates, declared war, made treaties, and passed laws- the people could "meet only on the summons of one of the higher magistrates, vote only on the proposals he chose to submit, select candidates from a list he set before it, and say only 'Yea' or 'Nay' to a law he proposed; it might contain hundreds of clauses, but no amendment was possible" (Brunt 1971: 46). Brunt also explains that "The assemblies of the people were also far from democratic. A majority was obtained not by counting heads but by counting units. ... Citizens who had virtually no property, the proletarii, formed only a single century, which voted last, if at all" (Brunt 1971: 46). 


\section{THE LEGALIZATION OF CITIZENSHIP}

In 451-450 в.C.E., Roman law was first codified. The codification of rights had an unintended side effect, changing the very character of citizenship. Instead of being associated with the ability, and indeed responsibility, to participate in the making of rules, citizenship now became associated with a set of codified rights and protections. Access to this system, however, was complicated and demanded prerequisites. Legal procedure was a secret of the pontiffs, and a litigant could be nonsuited for using a single wrong word in a formula (Brunt 1971: 54). This development is highly relevant to the argument of this book, as it not only signals the beginning of the separation of the state from society-which then triggered the codification of rights and protections from the state-but also signals the depoliticization of the life of citizens, which thus opened the door for their separation and alienation from politics, government, and the state.

John Pocock (1995) has focused his attention on the Roman lawyer Gaius (130-180 C.E.) as one of the main agents in this process of legalizing the political—but we must suppose that this process started much earlier, namely, when Roman law started to be codified. I thus follow Pocock's logic, without necessarily following his timeline. Pocock explains that Gaius was instrumental in shifting the meaning of "citizen" from a political being to a legal being. According to Pocock, after Gaius, citizens defined themselves vis-à-vis their possessions, and they carried these definitions into the public realm. For Pocock, this represented "the origins of possessive individualism" (Pocock 1995: 35). Pocock further explains that in Rome, "citizenship has become a legal status, carrying with it rights to certain things_-perhaps possessions, perhaps immunities, perhaps expectations - available in many kinds and degrees, available or unavailable to many kinds of persons for many kinds of reasons" (Pocock 1995: 36). What emerged was, in Pocock's words, a "homo legalis"- that is, no longer a political man, actively involved in making the rules of his or her community, but instead a person subject to the rule of law, where the law was not of his or her own making. This change indeed profoundly altered what it meant to be a citizen. Instead of being part of the state and the authority, Roman citizens, especially the less fortunate ones, had to live under a system not of their own making and needed to address any wrongdoings against them to the judicial assembly, instead of addressing them in the legislative assembly, to which they no longer had access. At the same time, as Pocock also demonstrates, property and the right to property became a legal condition for citizenship, which resulted in the 
characterization of groups that owned no property as "savages," who were then placed outside of citizenship.

\section{LESSONS FROM ROME}

Romans extended citizenship to a far larger group of people- after conquering them. In doing so, they secured their allegiance. However, extending citizenship rights to so many triggered a countermovement that had two related dynamics: first, it led to the establishment of a political class of rich and powerful citizens who became first-class citizens, and degraded ordinary citizens to a second-class status; secondly, a system of representation was established so that the first class of citizens made decisions for and no longer with all the people who lived under the jurisdiction of the laws they passed. Democratic elite rule was thus established, and the true seed of democracy-namely, self-rule-was killed. The motivation to concentrate political power in the hands of the few was not triggered by larger numbers of citizens per se, but by the will of those who had privileged access to the spheres of power to preserve their advantages, as Mouritsen (2001) seems to think and as the violent reactions by elite senators against the democratic reforms proposed by the Gracchi brothers further demonstrate. In 133 в.C.E., when Tiberius Gracchus proposed land reform and an extension of Roman citizenship to Latin allies directly to the popular assembly, thus sidestepping the senate, he was clubbed to death by Roman senators (Stockton 1979, Syme 1956, Scullard 1982).

This movement away from self-rule, which makes sense if analyzed under the prism of citizenship as an asset, was further strengthened, it appears, by the codification of laws and the transformation of political citizenship into legal citizenship that this process automatically produced. Even though Pocock (1995) focuses on a time when the Roman Republic had already given way to empire, his analysis still proves insightful in that it highlights the change of character that such a process potentially entails. As a result of the codification of law, political aspects of citizenship were transformed into legal ones. Because the channels for self-rule and direct participation were restricted, the legalization of politics finally closed off the realm of politics to ordinary citizens. From now on (even though we do not know with certainty when this now exactly was), the majority of Roman citizens became bystanders and audiences of the political life exercised by the few in their name and, supposedly, on their behalf. Democracy as self-rule and as 
a way to live with, maybe even within, politics had given way to a system of representation by political elites, who were, at the same time, the social and economic elites of the society they controlled.

\section{CONCLUSION}

Societal inequalities present a formidable obstacle to democratic self-rule. If societies are deeply divided, and if some of its members are not recognized as full members, democracy runs the risk of producing a concentration of power in the hands of what we might call a "structural minority"-that is, in the hands of one class of people. This risk becomes an even further threat when democracy is exercised merely in the form of representation, as representation automatically implies not only that some people will decide for others, but also that some people remain outside of, and are potentially alienated from, the political process. Under conditions of extreme and normalized inequality - that is, where some people are perceived as "natural leaders," "superior," or a "political class"- there is great risk that democracy decays into elite rule, where the rulers dominate public and political affairs and serve their own interests. The more general problem out of which this phenomenon emerges is that societal inequalities have the proclivity to spill over and contaminate the political process of a democracy.

One way to confront this risk is by targeting societal inequalities. Marxist approaches confront societal inequalities in order to achieve political equality. The cost of this strategy has become apparent in all those countries where the state started to regulate and control private affairs for the sake of the common good. At this stage in time, it is fairly safe to say that this strategy has failed, because the price we have to pay for achieving societal equality is too high. Even the less radical social-democratic welfare approaches that characterize most advanced capitalist systems aim at ameliorating economic inequalities in order to achieve some degree of distributional justice. However, these, too, do not successfully address political equality, as even after these measures are taken, the remaining inequalities tend to spill over into the political realm. Furthermore, any measure aimed at economic redistribution necessarily creates a conflict between collective, distributional justice and individual justice (Rawls 1999). Furthermore, economic redistribution creates economic disincentives, which create not only economic problems, but political ones as well.

However, the severest shortcoming of economic strategies is that they 
do nothing to address the political inequalities that characterize all contemporary democracies. If political equality of voice and citizenship is our aim, then our strategy must focus on those-and not on economic inequalities, as it is utopian to the extreme (and undesirable indeed) to think that we will one day achieve total economic equality. Even if we could, there is no guarantee that out of economic equality political inequality would result.

Cleisthenes approached this problem from an altogether different angle, one that was more strictly political. Cleisthenes recognized that Greek society was economically divided and hierarchically structured. Instead of seeking to fight inequality in society, Cleisthenes sought to first devise institutions that cut across the ethnic, religious, and socioeconomic bonds that structured Greek society, and second to design institutions that blocked a spilling over of societal inequalities into the political realm. By designing collective decision-making institutions that overlapped and cut across existing societal cleavages, he designed a system where people of different backgrounds had to come together and make collective decisions. Combined with the older practice of assigning public offices by lot, the ancient Greek model of democracy not only broke down the distinction between rulers and ruled, it also sought to ensure that societal cleavages and associations would not lead to the consolidation of a ruling class. Concretely, according to Jones (1999), "The new phylai, trittyes, and demes, but especially the demes, it is argued, were set up as rivals to an already existing network of regionally based aristocratic cultic associations. The democratic units were meant to bypass, divide, duplicate, or otherwise neutralize their aristocratic predecessors" (Jones 1999: 55; also Finley 1962: 4, 16). ${ }^{6}$

Democracy and citizenship thus started strong in Athens-and because it was so strong and meant so much, it was highly restrictive and exclusionary. Only a minority could enjoy the rights that came with it. It is also clear that the rights and entitlements of being an Athenian citizen were considerable and thus coveted. However, inseparably linked to the rights of being an Athenian citizen came considerable responsibilities. One was busy as a citizen, and citizens could not escape the duties their status demanded, as many offices were drawn by lot. Alienation from politics, under such circumstances, was virtually impossible. The people were the government and the people were the state. There was no "us" versus "them" —at least not in the political realm. There was, however, great societal inequality and vast inequalities of wealth. Instead of seeking to undo those, which would have required invading the private sphere of the household, such politicians as Solon, Cleisthenes, and Ephialtes rather sought to address them in a strictly 
political way: by devising institutions that aimed at neutralizing societal inequalities in the sphere of politics.

The guiding principle for all three Athenian statesmen analyzed here was that of justice. The core principle here was that of mixing. Mixing meant forcing the rich to share political associations with the poor. This was accompanied by splitting: splitting up family clans so that civic bonds could replace family bonds - and one can easily extend this logic and apply it to clan, descent, "blood," or ethnic bonds. Democracy, to these reformers, then meant that the people ruled on an equal basis, and that no other bonds interfered or even replaced the bond that connected them to the polis, that is, the other citizens.

This provides the first important lesson we can learn from classical Athens, something that the contemporary French philosopher Jacques Rancière (2004 and 2007) has also alerted us to more recently, namely, the clear separation of the social from the political realm. According to this logic, most problems are of a social nature, but the political is the realm where these social problems can and should be addressed. There are indeed few purely political problems, and most of them are not that serious. Problems of social inequality, however, tend to be very consequential politically.

Clearly, we have moved far away from these principles. While the Left has sought to undo social inequalities, thus violating people's individual rights and invading their private spheres, the Right has let go of any attempt to achieve civic bonds altogether.

Athens also provides important insights into the apparently inherent tradeoff between the quality of rights and the exclusivity of access to them. The more Athenian citizenship ensured tangible benefits, the more restrictive it became- a phenomenon that was worsened by the economic scarcity caused by defeat in the Peloponnesian War in 413 в.C.E. This confirms that thinking of citizenship as an asset allows for discerning new aspects of its regime.

The other important lesson from classical times comes from Rome. It appears that when extending citizenship to the many, powerful elites sought, and were able, to secure their own privileged access to the political system by introducing the idea of representation, and by legalizing citizenship rights. Living in the Roman Republic no longer meant ruling oneself. It meant having certain rights - and more of them if one was rich and powerful, as access to the legal system was complicated and dependent upon one's ability to hire the assistance of legal specialists who dominated the very formalistic language of the codes, as well as the forms and protocols that had to be followed in order to address the courts. This shift towards the codification of laws must be seen as the end of political 
citizenship. People no longer ruled themselves, and a distance separated them from the government, the state, and politics. This is also the beginning of even the possibility of feeling and effectively being alienated from politics, government, and the state.

It is this version of democracy and citizenship we have inherited and still practice today. The very few attempts at establishing something more direct have always been deemed radical and been quickly subdued. And radical it was, considering that in the Roman Republic we can also witness a very familiar phenomenon indeed: the rule of the rich. Starting in Rome, the rich ruled and did what they thought, and indeed knew, was best for the state, the country, or later the empire. And as they were the state, the country, and the empire, they did what was best for them.

Athens and Rome thus set the tone for how democracy and citizenship developed in the years, decades, and centuries to follow, and the parameters for the struggle over power, influence, control, rule, and exclusion were already set. 



\section{Medieval European Citizenship} Christian Rights and Jewish Duties

Without neglecting the fantastically rich and polyphonic complexity of the historical universe unfolding in Western Europe from the 12th century onwards, the most appropriate way to grasp its specificity is to relate it to the signification and the project of (social and individual) autonomy. The emergence of this project marks the break with the "true" Middle Ages.

-CORNELIUS CASTORIADIS, “THE RETREAT

FROM AUTONOMY: POST-MODERNISM AS

GENERALISED CONFORMISM,” 2001

IT WOULD CERTAINLY BE WRONG TO SAY THAT DEMOCRACY SUCcumbed after the collapse of the Roman Republic. The problem is rather one of historical sources - and the lack thereof. Democratic experiments in Africa, Asia, the Middle East, or the Pacific region are simply not as well documented to base an analysis of the dialectics of citizenship on them. ${ }^{1}$ The history of medieval European city-states, however, provides a rich case of analysis within the context of this book, as it allows for a highlighting of the advances of democratic self-rule on one side, and the contrasting exclusion from these city-states on the other.

Following the logic and rationale established earlier, which is not to compare cases, but rather to explore each one separately for salient characteristics, this chapter takes a closer look at the developments in Western Europe after the decline of the Roman Empire in the West in the sixth century C.E. Thus, whereas the previous chapter focused strongly on the included and what citizenship meant to them, this chapter takes a closer look at the excluded, 
how their exclusion was constructed and justified, and what their exclusion meant to them and to the democracies that practiced and enforced it.

Of special interest is the situation of the excluded group par excellence during this time period: Jews. The first focus in this chapter thus consists of an analysis of the relationship between Christian rights and Jewish duties and exclusion. The second interest pursued in this chapter is the analysis of the internal dynamics of the emerging, mostly Florentine, democratic republics, as they provide an example for a renewed attempt at self-rule and the pursuit of autonomy (Castoriadis 2001). This focus also allows me to continue the theme of a critique of the Western tradition.

In the West, with the decline of the Roman Empire came a decline of democratic principles and institutions, and feudalism dominated the political landscape. Roman Catholic religion became the universal eschatological principle, and around it, the Roman Catholic Church constructed a Manichean world of good and evil; believers and heathens; Christians, Jews, and Saracens; pious religious followers and rebellious witches. It was only when the Reformation started driving a wedge into the solid power of the Catholic Church, thus considerably weakening it, that democracy again found some space to expand, giving gradual rise to modern democracies and their dominant manifestation in nation-states (Zakaria 2003). Before that, democracy and citizenship were practiced only on a very small scale for a very limited period of time-for example, in a number of relatively small city republics in northern Italy, emerging around the late tenth century.

The scarcity of sources and the scantiness of our knowledge about what citizenship meant concretely during the long stretch of time from 44 B.C.E., when Julius Caesar effectively ended the Roman Republic and made himself dictator, to the late eighteenth century, when the American, French, and Haitian revolutions brought citizenship and democracy back to the European map, allows for only a very sketchy depiction of the dialectics of citizenship.

\section{CHRISTIAN RIGHTS, JEWISH DUTIES}

According to Leonard Glick (1999), during the eleventh century the development in Europe was marked by a double movement: as Christians prospered, Jews slid into a precarious situation. To some analysts, animosity and mutual hatred was such an integral part of medieval life that they called it a "structural fact of social and legal existence" (Bossy 1998: 54). Indeed, 
exclusion of such "others" as Jews was functional in strengthening the bond that united all those coming together to form communities during medieval times (Smail 2001: 94).

The question I seek to explore here is what were the causal relations that linked Christian prosperity and expanding citizenship to Jewish exclusion. According to Glick (1999), "For Christians the changes were in the form of remarkable social and economic advancement, while for Jews precisely the opposite was true. In other words, just as life began to improve for Christians, it began to worsen for Jews" (Glick 1999: 77). This chapter argues that the growth of Christian prosperity, which in part rested on the acquisition of civil and political rights in emerging free cities, was indeed causally connected to the decline of Jewish prosperity that occurred at the same time.

Under the title "Laws and Legal Status," Glick (1999) discusses the restrictions imposed on Jews in the kingdoms and states emerging at the fringes of the decaying Roman Empire. Jews had lived in the lands that came under Frankish, that is, Merovingian rule before Catholicism became dominant in the Roman Empire (after the conversion of Emperor Constantine in 336) and before Clovis, the Merovingian king of the Franks who followed the Roman model in 500 .

Under Roman law, since Constantine had granted freedom of religion in 313, Jews were granted the freedom to practice their religion. However, by the end of the fourth century, when Catholicism became the official religion of the Roman Empire, the situation of the Jews, together with that of other religious minorities, changed. Now, special provisions had to be enacted to regulate the treatment of these groups. In 388, Roman law prohibited intermarriage between Jews and Christians. In 423, it outlawed the ownership of Christian slaves by Jews. Frankish law followed suit, outlawing Christian-Jewish intermarriage in 533 (Glick 1999: 34f). According to Bachrach (1977), the growing number of restrictions against Jews that occurred towards the end of the Roman Empire is due to the fact that Jews "grew in power and prestige" during the sixth century (Bachrach 1977: 64).

In 582, Chilperic, then king of the Franks and heir to the Merovingian throne, ordered all Jews of the kingdom to be baptized (Glick 1999: 37). Although this campaign was not entirely successful, it forced Jews to hide or move, and the baptism campaigns continued (at least up to the last of the Merovingians, Dagobert, in 629).

The beginning of the First Crusade abounds with stories of massacres of entire Jewish communities - for example, those living in the cities of Speyer, Worms, Mainz, and Cologne, all of which happened in the year 
1096 - all conducted by crusaders under the command of Count Emicho, described as "a minor landholder in Upper Loraine" and "a man of very ill repute on account of his tyrannical mode of life" (Glick 1999: 95). Emicho's band never made it to Jerusalem, and most were killed in Hungary, on their way east. The Christian chronicler Albert of Aix provided this comment about Emicho: "So the hand of the Lord is believed to have been against the pilgrims, who had sinned by excessive impurity and fornication, and who had slaughtered the exile Jews through greed of money, rather than for the sake of God's justice, although the Jews were opposed to Christ" (quoted in Glick 1999: 102).

As this comment amply demonstrates, the religious fervor sparked by the call for a holy war, uttered by Pope Urban II in November 1095 in Clermont, France, offered many opportunities to become rich by stealing money from Jews. While some Christians resorted to simply killing Jews in order to take their money and property, others-mostly those in situations of power, such as bishops, priests, and lords - used the occasion to ask the Jews for ransoms in order to protect them from the incited mobs. One way or another, Jewish wealth thus passed into Christian hands, and in most cases, the paying of fees and giving of gifts to which the Jews resorted in order to save their lives did not prevent their eventual killing by the crusaders and all those inspired by their example.

During the twelfth century in general, "as Christians progressed and prospered, Jews became pariahs" (Glick 1999: 115). Glick argues that this was particularly the case for Jewish political rights. Whereas European Christians were able to carve out more political and civil rights for themselves (although still of limited nature), the advance was negotiated by pushing the Jews among them into a status of dependence-a dependence that was used to extract money from them in return for protection and tutelage. For Glick, "The clearest evidence for this trend was in their changing political rights. The charters that had been issued to Jews earlier-Louis's ninth century charters to individual Jewish merchants, for example, or the Speyer charter of 1084 to an entire community-had one thing in common: The Jews were assumed to be independent persons, free to decide where they lived and on what terms. But now they were becoming dependent; they were assumed to be helpless, in need of protection and obliged to please their protectors" (Glick 1999: 115).

By declaring the Jews in need of protection, the Christian kings and dukes who passed such measures relegated them to a second-class citizenship status - a status they shared with women and children. It was also during this time that Jewish business activity was by decree restricted to money 
lending, which thus created a situation of even higher risk: confined to lending money and dependent on the protection of their overlords, Jews needed to pay for their safety and were always at risk of falling victim to pogroms whenever their payment was not enough and their overlords thought that more money could be gained by simply taking it from them. On top of that, Jews were now constantly at risk of being accused of usury. As Christian rights progressed, Jewish rights became more and more restricted.

\section{FREE CITY REPUBLICS}

Citizenship is invariably linked to the development of cities. This was the case with classical citizenship as practiced in Athens and Rome, and it was again the case in post-imperial Europe, once the unifying institutions of the Roman Empire had faded (Holston and Appardurai 1996). Once more, out of the political power vacuum created by absent or distant overlords, people sharing a location started to press for political autonomy and self-rule, thus opposing the claims of feudal lords for authority over land and people. However, much as was the case in Athens and Rome, the reemerging citizenship of early medieval Europe was heavily circumscribed and exclusive; after all, and following the theoretical approach developed earlier, citizenship was, and continues to be, a highly disputed good, precisely because it provided those able to claim it with privileges and special rights. However, according to the classic study by Bella Duffy in 1892, these emerging communes "were not, as at one time believed, the lineal descendants of the Roman municipalities" (Duffy 2011: 1). Instead, something qualitatively new emerged in medieval Europe.

City republics emerged from the power vacuum left by the crumbling Carolingian empire, towards the end of the ninth century. Into this vacuum, Catholic Church officials stepped, ordering not just religious life, but commercial, military, and civic as well. However, not everybody was happy with the rule of kings and bishops. According to Daniel Waley and Trevor Dean (2010), there were three causes that led to the emergence of city republics in northern Italy, where this phenomenon took root the most. First, emperors were too distant and unable to provide the kind of governance that some thriving commercial centers needed. Second, the secular power of bishops was challenged from within by the ecclesiastical reform movement, which demanded a retreat of the Church to things religious. Finally, as transregional trade expanded, different people from different places started coming, and 
settling, in such emerging commercial centers as Milan or Siena. These newcomers did not readily accept the authority of the bishop and oftentimes rebelled against it.

Indeed, the development of city communes was intimately linked to trade. According to Max Weber (1968), "The circumstance that the city was a market with relatively permanent opportunities to earn money through commerce or the trades induced many lords to exploit their slaves and serfs not as workers in their own houses or enterprises but as sources of annuities; they trained them to be artisans or small merchants and permitted them to pursue their livelihood in the city in return for the payment of a body rent (Leibzins); at times (as in Antiquity) they also equipped them with working capital" (Weber 1968: 1238).

Trade, as stated above, brought newcomers to town, and among those newcomers were also traders from further away. To the south, once the Saracens had conquered southern Italy in 823, Muslim traders introduced new products and offered new outlets—including slaves (Duffy 2011:8). Among the new traders were also Jews, who were especially active and present in coastal towns. As a result, the free towns constituted themselves in the north of Italy as communities of faith (Weber 1968), and they also emerged as homogeneous communities against an increased populational heterogeneity.

The communes that emerged slowly wrested power from kings and bishops, via concessions. Such was the case, for example, with Lucca, which secured a concession from Henry IV in 1081 not to build castles within six miles of the city, and no building within its city limits. "Henry also renounced jurisdiction within the city of Pisa and promised to name no new marquis in Tuscany without the consent of the Pisans" (Waley and Dean 2010: 9f). Apparently, such concessions were preferable to the violent uprisings that some cities had organized when their claims were denied. To Waley and Dean (2010), "Communes filled these gaps, providing effective connections between political power and local elites" (Waley and Dean 2010: 10).

The ways other communes emerged in this region are very similar. "First, we have the Marquis, or his representative the viscount, of Teutonic origin, presiding in the courts, surrounded by his Scabini, or judges, who, although in one sense imperial officers, seem nevertheless to have been chosen usually from among the inhabitants of each town and territory, and not to have travelled about in the suite of the overlord" (Duffy 2011: 3). According to Duffy, these relatively independent Scabini gave the starting impulse for further independence.

Duffy also highlights the fact that such a development occurred 
in northern Italy precisely because the bishop was less influential than elsewhere-and the German overlord, in the figure of the marquis, was relatively distant. What emerged in Tuscany, as a result, typically was a relatively small commune of free citizens, who regularly met in a popular assembly and, so assembled, elected "twelve principal citizens, who are variously distinguished as Buoni uomini, Sapientes, or Majores. Thirty years or so later, these Buoni uomini are fewer in number, and have received the title of Consuls" (Duffy 2011: 6).

Once these communities had reached maturity, the people of the lower classes were able to challenge the dominance of the richer merchants and craftsmen, especially by creating powerful guilds. Social parties and associations also started to emerge. In fourteenth-century Florence, for example, social parties formed around income and social standing, thus constituting a party of the upper-middle class (Grassi), one of the middle class (Mediani), and one of the lower class (Minuti). High-ranking officials were now elected from those three. According to Duffy (2011), "In little more than one year Florence had undergone four changes of government, the final result of which was to strengthen the power of the two lower classes at the expense of those rich and powerful members of the community who, whenever the grandi succumbed, had remained the dominant faction" (Duffy 2011: 162f).

Indeed, in the first half of the fourteenth century, Florence's rich and powerful citizens lost so much influence in the administration and management of city affairs that many withdrew to the countryside out of frustration. However, this rise of the lower guilds was soon met by concerted efforts of the higher guilds, who sought to control the power of the lower classes by establishing an oligarchy. According to Duffy (2011), "In 1371, the supremacy, thus obtained, of the Ricci and Albizzi, was felt to be so intolerable that the people named a commission, or Balia of fifty-six members, for the express purpose of excluding those two families entirely from office" (Duffy 2011: 174). Continued discontent among the people of Florence finally led to a violent popular uprising, in June 1378, through which the lower classes of Florence secured their influence in city politics. Their influence lasted until 1433, when Cosimo de' Medici's tyranny finally ended the communal republic of Florence. Towards the end of the fifteenth century, all of the citizen republics of northern Italy finally succumbed to the competing influences of Pope Francesco della Rovere, Sixtus IV, and Lorenzo de Medici, the Magnificent (Duffy 2011: 298f).

According to Max Weber (1968), "To develop into a city-commune, a settlement had to be of the nonagricultural-commercial type, at least to a 
relative extent, and to be equipped with the following features: 1 . a fortification; 2 . a market; 3 . its own court of law and, at least in part, autonomous law; 4. an associational structure (Verbandscharakter) and, connected therewith, 5. at least partial autonomy and autocephaly, which includes administration by authorities in whose appointment the burghers could in some form participate" (Weber 1968: 1226).

One of the core features of these free cities was their relatively small size. Very few had more than 20,000 inhabitants. This small size was also grounded in the conviction that for a community to work, its members had to know and be able to discuss daily affairs with each other. Just like Plato and Aristotle, medieval city leaders thought that 100,000 inhabitants was the upper limit of viability for a republic (Waley and Dean 2010: xxi).

Weber also explains the principle of "Stadtluft macht frei"- "city air makes free," because the economic opportunity that cities offered allowed many to purchase their freedom from slavery or serfdom and join the commune of free citizens (Weber 1968: 1238). Indeed, according to Weber, "The urban citizenry therefore usurped the right to dissolve the bonds of seigniorial domination; this was the great-in fact, the revolutionary-innovation which differentiated the medieval Occidental cities from all others. In the central and northern European cities appeared the well-known principle that Stadtluft macht frei, which meant that after a varying but always relatively short time the master of a slave or serf lost their right to reclaim him" (Weber 1968: 1239).

In most cases, the time it took to actually become a free member of the city commune was not so short-typically one year and one day, but sometimes much longer than that-and it was also bound to a series of conditions, such as buying a house and thus becoming a resident and being able to pay a minimum amount of taxes. It was also conditional upon a whole list of duties and responsibilities. Still, free city communes offered a way to escape the rule of the feudal lord and to become a free citizen.

In fact, citizenship in the early Italian city republics implied more duties than rights - and it was not enough to be a formal citizen in order to be eligible for administrative office (Waley and Dean 2010: 62). The requirements and duties of citizenship included loyalty to the commune, obeying its laws and officers, performing military service, attending meetings, paying taxes, and others. Citizens in these city republics were required to regularly participate in the great assemblies, called arengos, which met regularly to decide major collective matters. The size of such arengos varied from some two hundred up to four thousand (Waley and Dean, 2010: 36).

In addition, citizenship meant active office in one of the many civic and 
military organizations responsible for conducting and regulating city life. Waley and Dean (2010) stipulate that similar to the Athenian democracy, in the medieval north Italian city republics, about one third of citizens held office every year (Waley and Dean 2010: 65f).

In most cases, citizenship also required owning a house in the city. Such was the case, for example, in Parma and Pisa. In Pisa, effective residence of at least nine months of the year was another condition for citizenship. According to Waley and Dean (2010),

Pisa also demanded a birth qualification (the citizen or his father had to be born within the city or contado) and a period of residence, originally twenty-five or twenty years, though later this was reduced to ten and even three (1319). (Waley and Dean, 2000: 63)

Furthermore, in most cases, citizenship required a certain income and excluded certain groups due to their lack of ability to pay taxes, or lack of regular residence (such as sailors, agricultural laborers, landless men, and herdsmen). In Florence, for example, participation in the general assembly, which constituted a parliament, excluded "the working classes and lower orders or plebs as well as the inhabitants of the contado [municipality]" (Duffy 2011: 56) during the twelfth century. The exclusion of women, serfs, Jews, Muslims, and slaves in the twelfth century was perceived as so "natural" that it went without mentioning.

Citizens, in the city republics we are looking at, tended to be internally divided into at least two main factions, namely, nobles and populari (Waley and Dean 2010: 128). Nobles were those landholding aristocrats and knights who were actively present and engaged in city business. Nobles, in many Italian republics, had their own association, the societas militum, or association of knights, and the cities relied on the knights, particularly at the beginning of these communes, for protection. These knightly associations existed alongside- and often in opposition to- the ones of the commoners, called societas populi. Blanshei (1976) has shown that in the commune of Perugia, most internal conflict was rooted in the attempts of traditional families to defend their inherited privileges against the newcomers who sought to ascend politically, after having already ascended economically. For Blanshei, conflict arose when reform programs, aimed at integrating these newcomers, "conflicted with the older established families' privileges and immunities" (Blanshei 1976: 11).

The nobles residing in the city, together with their allies who controlled the country, were able to take control over all Italian city republics during 
the fourteenth century, thus effectively ending the republican experiments in this region and substituting them with feudalism.

Furthermore, and paralleling the general pattern of Christian ascent bought with Jewish oppression, free cities were first and foremost religious communities that relied on sharing worship as a central means of strengthening and renewing the horizontal bonds that united all citizens against aristocratic owners of lands and peasants. According to Weber, "The fully developed ancient and medieval city was above all constituted, or at least interpreted, as a fraternal association, as a rule equipped with a corresponding religious symbol for the associational cult of the burghers: a city-god or city-saint to whom only the burghers had access" (Weber 1968: 1241). Typically, Jews were thus not allowed to become members and citizens of the commune. As in the case of Venice, they were indeed only permitted to settle within the city limits once the republic had fallen, in 1509 (Finlay 1982: 140).

In Antiquity,

membership in one of these associations remained the distinguishing mark of the citizen with full rights, entitled to participation in the religious cult and qualified for all offices which required communication with the gods (in Rome: participation in the auspicial). It was the need to qualify for participation in the religious rites which made such membership indispensable, for an association with claims to legitimacy could rest only on the basis of the traditional, ritually oriented organizational forms such as the clan, the military association (phratrie), and the political tribal association (phyle), or at least had to create such a basis by fiction. All this was quite different in the medieval "founded" cities, particularly in the North. Here, at least in a new foundation, the burgher joined the citizenry as an individual, and as an individual he swore the oath of citizenship. His personal membership in the local association of the city guaranteed his legal status as a burgher, not his tribe of sib. (Weber 1968: 1246)

Jews, thus, could not be full members and were relegated to the status of guests. As Weber explains, "The ritual exclusion of connubium —otherwise foreign to the Occident-and the actual impediments to table community between Jews and non-Jews, but above all the absence of a common share in the ritual of the Lord's Supper, effectively prevented fraternization. The medieval city, after all, was still a cultic association. . . . The Jews, therefore, remained from the beginning outside the burgher association" (Weber 1968: 1246f). 


\section{FROM CITY STATES TO FEUDAL STATES AND EMPIRES}

During the fifteenth century, European city-states fell prey to imperial expansion, and most were defeated and integrated into the emerging empires. However, not all of them vanished. As late as in the seventeenth century,

there were some 4000 of what Mack Walker has called the German "home towns," most of them with between 750 and 10,000 inhabitants. Altogether, these towns housed a quarter of the entire German population. Thus, the history of one German in four in the seventeenth century is not that of the major territorial states, but that of Freudenstadt, Nordlingen, Esslingen, Braunschweig, Hildesheim, Bamberg, Eichstatt, Würzburg, Tübingen or a host of others. In towns such as these, guilds and craft organizations remained the basis of social and economic life. Nahrung — social justice, or more specifically the protection of a just standard of living through economic self-sufficiency—remained the ideal of such organizations. (Mackenney 1989: 37)

Prime examples of cities that maintained political autonomy also include London, Leiden, Hamburg, and Frankfurt. City-states thus survived in Europe, even though democratic city-states were rare and their degree of "democraticness" limited. Guilds played an ambivalent role in this regard: On one hand they were the powerful organizations representing the interests of the burghers, that is, of craftsmen and traders-against feudal lords and the Church. At the same time, however, "the guilds opposed any attempt to ease the entry of members of the minority groups into the ranks of citizens, which meant that the limited civil liberties of immigrants were never translated into political freedoms" (Mackenney 1989: 37). And even though in some places the power of guilds was broken, as in Frankfurt, where all guilds were abolished after the artisan uprising of 1612-16, "the crafts retained immense influence" (Mackenney 1989: 38). Medieval guilds thus exemplify the dialectical dynamics between wresting rights away from overlords and replacing them with horizontal bonds among common citizens, only to replace such a regime of vertical dependence with one that is even more exclusionary. Once a community of equals is established, membership to this community becomes a matter of extreme dispute and circumscription.

Just as in earlier times, Jews, made to reside outside of Christian communes and relegated to do the one trade that Christian observance forbade-money lending with interest (that is, usury) — remained outsiders. Christian citizens wanted their money and relied on their international connections - the fruit of age-old persecution and the resultant dispersion—but did not grant them 
equal status. The same remained true for women, the poor, the landless, and all those not owning their own homes. Thus, not much had changed since Athens and Rome, where the luxury of citizenship was equally bought with the free labor of slaves, women, serfs, and foreigners. The situation of European Jews thus provides but one example of a more pervasive phenomenon. It is, however, a very telling example, and the history of Jewish pogroms and gzeirots are indeed too numerous to count. In this respect, Austria-Hungary is a particularly telling case, due to its significant Jewish population. In 1744, for example, Maria Theresa, monarch of Austria, ordered a gzeirot, the "total and immediate expulsion of the distinguished and long-settled Jewish community of Prague. It was to be carried out almost immediately. It was to be followed in short order by the expulsion of all Jews from all of Bohemia and Moravia" (Vital 1999: 1).

Although the Jewish community of Prague was able to avoid expulsion in 1744 by paying lots of money, the history of Jews in Europe is full of similar episodes - and so is the expectation that Jews needed to pay dearly for their survival, peace, or to remain in a given city, county, or land. At one point or another, Jews were expelled, be it from emerging medieval citystates or from the emerging nation-states of England (1290), France (1306), Germany (1348), Lithuania (1445), Spain (1492), and Portugal (1497).

According to Vital (1999), "Underlying everything was the central fact that under the old regime no Jew was, or could be, a member of (civil) society. No matter how learned or wealthy or contingently influential he might be within or without Jewry itself, a Jew was held to belong to a moral and, of course, theological category inferior to that of the meanest peasant" (Vital 1999: 6).

Even though in 1782, Joseph II, emperor of Austria, passed a patent of tolerance (Toleranzpatent) and thus lifted many of the professional and social restrictions his mother had imposed on the life of Jews, none of these concessions came with citizenship. Vital (1999) explains that "The emperor's rescript specifically laid down that the right of admission to certain occupations and institutions did not carry with it the right of citizenship and craft mastership. From these the Jews 'remained excluded' [wovon sie ausgeschlossen bleiben]" (Vital 1999: 36).

Jews were never treated as equal members in prerevolutionary Europe, no matter where one looks. The reason everywhere was that they were not trusted as members of faith-be it the Christian faith, or the faith and allegiance to the sovereign (Kim 2004). In the words of Vital (1999), "The difficulty about the Jews was that, over and above all the old objections to their presence, they seemed to present an insuperable obstacle to the 
establishment of just such a coherent, smoothly operating centrally directed social order as was striven for" (Vital 1999: 32).

When considered at all, they were discussed for what could be obtainedand more often than not squeezed-from them, which in most cases meant money. However, while newly emerging and rationalizing European states sought to increase their control over Jews by forcing them to conform, their evaluation was always predicated by deep-seated prejudice. According to Vital (1999), "Nothing was rarer than for those who for one reason or another addressed themselves, however briefly, to the matter of the Jews than to begin, at least implicitly-and as often as not explicitly-with the proposition that they were not only hopelessly stubborn and difficult to deal with, but in many ways depraved, ignorant, and unclean" (Vital 1999: 33).

The tropes about uncleanliness, being unfit to join a "civilized community," of being depraved and sexually overactive, repeat themselves in history and seem to stem from the same motivation to establish pure and "clean"- that is homogeneous-communities that ethnic and religious "others" threaten to pollute, penetrate, and violate. Others are always those who are not only physically close, but with whom the hegemonic group is intimately connected and thus dependent on. Hence the sexually loaded language (Bauman 2001). This reality also hints at the need to establish, and maintain, a tight-knit community able to retain sovereignty. The more power it wielded, the more anxious its members were to defend it against any form of "penetration" or "pollution" from outsiders.

\section{THE SPECIAL CASE OF POLAND}

There are a few examples where Jews were given rights, and it is thus worth taking a closer look at these cases. In 1264, the Polish prince Boleslaw the Pious decreed the privilegium principle, which declared that Jews did not fall under the same legal code as Christians, effectively giving Jews a special status. Some one hundred years later, this special status was extended to the whole of Poland by Casimir the Great. Under this privilegium, Jews were given the right to handle all civil cases involving only Jews themselves, through rabbinical courts. Hence, the Christian Church, the Christian nobility, and the Christian urban patriciate could no longer judge Jews in cases that only involved civil disputes among themselves. According to Vital (1999), "Considering that in Old Poland, as elsewhere in the Middle Ages, judicial authority was a prime symbol of government as well as one of its major instruments, these 
were remarkable concessions. They highlighted the formal separation of the Jews from the rest of the body politic" (Vital 1999: 8).

Indeed, in many of the Polish estates, Jews could look back at a long history of tolerance-even if the application of royal tolerance or privilege decrees depended on the local sovereigns that controlled the different estates making up the Polish territory. This was of particular importance during the many times when unity under one king was lost and Poland consisted of a series of dukedoms. In general terms, however — as the quote above demonstrates - the condition for tolerance was that Jews kept themselves apart and did not integrate, or even mingle, with Christians (Teller, Teter, and Polonsky 2010). This only changed in the late eighteenth century, when Polish Jews were granted civil rights and released from constraints. They were even permitted to purchase and own land and housing. They were also allowed to retain a degree of juridical autonomy and permitted to wear their characteristic dress and beards (Polonsky 2009). However, even this integration came with a price-in the concrete sense of the term. "The money by which the nobility, the Church, and the burghers - and the crown itself - were to be paid off in exchange for their acquiescence in this radical change would come from the Jews themselves" (Vital 1999: 73).

In eighteenth-century Poland, the nobility had been opposed to giving non-Catholics political rights. They were only admitted to municipal citizenship in 1775 (Vital 1999: 74). However, the strongest opposition to all changes in the status of the Jews was voiced by the middle-class burghers, because they perceived urban Jews as competitors and thus strongly pressed for their exclusion from urban citizenship rights. Urban citizenship, especially in those towns that did not belong to the Christian Church or to some landlord, brought with it the right to join a guild and thus to be allowed to conduct business in the town, be it as a craftsman or a merchant. As elsewhere in Europe, urban citizenship also brought the right to participate in the making of municipal law, voting, and holding public office. It was precisely in those free towns that the burghers opposed Jewish membership the most, confirming the general pattern detected thus far-namely, that the value of Christian citizenship was established, at least in part, by contrasting it with Jewish non-rights and exclusion.

Reforms to Jewish citizenship only came after 1789, in the wake of much broader Polish state formation. However, even then, Christian power holders and political elites in general perceived it as entirely normal that Jews had to pay—and pay heavily_-for whatever right or entitlement they wanted to have.

Later developments in those European states that counted on relatively 
strong Jewish communities all follow a similar pattern. In the AustroHungarian Empire, after 1818, the state relied heavily on extra payments made regularly by Jews, and it was taken for granted that Christian privileges and rights had to be sustained and financed through Jewish special duties. So even after the French Revolution, Jews remained "a people apart," and their admittance to the community of Christians was dependent on what they had to offer in return-thus instrumental, and not driven by a genuine will to integrate them and give them equal-citizen status.

Jewish citizenship in Europe remained tenuous and tentative, continuously threatened and invaded, its substantiveness challenged or invalidated in daily interactions. In nineteenth-century Prussia, for example, Jews were granted formal citizenship only in 1869, and formal citizenship was a far cry from substantive citizenship and being able (and allowed by one's "fellow" citizens) to actually live and practice the social role of being a full citizen. As Vital (1999) argues, "While the principle of full equality was conceded in principle it was only grudgingly and incompletely accorded in practice: the unwritten, but almost total, ban on the inclusion of Jews into the official civil and military hierarchies (with the partial exception of the lower judiciary) was retained" (Vital 1999: 177).

The French Revolution changed little in this respect. If anything, as the European developments of 1933 to 1945 demonstrate, once Jews became effectively more secularized and more integrated, the irrational fear of sneaky pollution and hidden penetration only increased (Bauman 2001).

\section{CONCLUSION}

After citizenship succumbed to empire in Athens and Rome, it reemerged in several, mostly small, cities in Tuscany. Before these cities were able to declare themselves sovereign, limited citizenship rights were granted by kings, emperors, marquises, dukes, and the like to their subjects. After the Tuscan city republics were swallowed up by the Catholic Church and the worldly powers with which it was at times united, the situation fell back to a granting of certain, although limited, rights to subjects. In this chapter, I have sought to analyze all three of these scenarios: citizenship before the city republics, during the city republics, and afterwards.

The situation of the city republics allows us to detect clear parallels to the classical period, especially Athens. In places like Florence, citizenship meant a lot to all those who were citizens. More than rights, it implied 
duties. However, the rights and entitlements derived from citizenship were also considerable - and valued enough to be under constant dispute and siege. Similar also to the classical examples, citizenship in one of the Tuscan towns was very exclusive and circumscribed. Slaves, serfs, women, and generally the poor were not granted membership. Particularly the poor, at least those residing within the city walls, constantly challenged their own exclusion and were able to carve out more rights for themselves-as happened, for example, in fourteenth-century Florence. However, the ascent of the lower classes to power almost always marked the beginning of the end of these republics, as it gave rise to violent reactions by the rich citizens.

When citizens were internally divided, it became easier for their much more powerful outside enemies to succeed, so that the rise of the lower classes during the fourteenth century brought the end of those republics.

A constant of any self-ruling community in Europe, from classical times to modern states, was its faith-based character. Faith, as Kim (2004) explains for England, was the number one condition for membership: faith in the same God, and at the same time faith in the sovereign and in the rules emanating from the sovereign-even if the collective was the sovereign, in which case "allegiance" would be a more adequate term. The sharing of Christian ritual, as Max Weber explains, sealed the pact that the members of such communities made and gave it strength.

This is precisely where the exclusionary character of such pacts emerges. As during most of Europe's history, civic pacts were religious pacts, and Jews were not allowed to join. How exactly this exclusion of the Jews unfolded before, during, and after the city republics is highlighted throughout this chapter. It becomes clear that the Jews provided an important background against which the privilege of Christian citizenship was constructed. Whereas slaves, women, serfs, and the poor provided the labor, the Jews allowed for an active engagement in commerce and trade. They were also functional in the construction of the first banks. But more than fulfilling instrumental roles that allowed for the accumulation of profits, Jews served the purpose of contrasting the "pure" inside group of fellow Christians to their "impure" outsider status. This is because such tropes as homogeneity and purity can only work if contrasted to something else, and nothing and no group can be pure and homogeneous by itself.

What emerges, then, from this succinct genealogy of citizenship is its inherent contradiction, which manifests itself in its exclusionary trait. The following cases, focusing on contemporary democracies, will add validity to this characteristic and further explore the different facets and limits, or tradeoffs, of democratic self-rule. 


\section{France}

\section{Liberalism Unveiled}

People always talk about Liberté, Egalité, Fraternité, and yes, there is freedom, but not everywhere and for everyone. Remember, we're French; we were born here. Our grandparents fought in wars to defend France. Back then, they were considered unsuitable, and today so are we.

—SIYAKHA TRAORÉ, “OPEN LETTER TO FRANCE,” 2006

France is a CRUCial Case in this Study. France presents itselfand is widely imaged —as being the next step from, or the natural continuation of, the ancient Greek invention of democracy. France thus is important historically. It is, however, also important conceptually, as France to this day stands out as a nation that has held onto the liberal republican traditions that motivated the French Revolution. The Fifth Republic still is a place where special rights and associations, and the privileges that such association could represent, are actively undermined. The unitarian French state only recognizes individual citizens and is weary of the special interests that easily grow out of secondary associations.

The history, and justification, of such a philosophy and the public policies it triggers can easily be found in French history. As Alexis de Tocqueville (1955) explains, "The revolution set out to replace feudal institutions with a new social and political order, at once simple and more uniform, based on the concept of the equality of all men" (Tocqueville 1955: 20). Aristocrats and the Catholic Church had, of course, created powerful associations that claimed significant privileges for themselves. Aristocrats did not pay taxes and towards the end of the eighteenth century had very few administrative 
tasks-thus living in a situation with many privileges and few, almost no, obligations. The situation of the Roman Catholic Church was no different. This institution, too, had important privileges that were not matched by concrete responsibilities towards the collective.

The French revolutionaries did away with the privileges of the aristocracy and the Church. Their associations were prohibited, their special rights to land, taxes, and rent-derived income canceled. Many aristocrats and clerics died swift deaths delivered the modern way, by the guillotine. The New France decided not to tolerate any interest groups and associations; no "special" groups with special rights and privileges survived. The Declaration of the Rights of Man and the Citizen was adopted in August 1789 by the National Constituent Assembly. It was the first step toward writing a new constitution for France, which was ratified in 1791. The declaration of 1789 became the preamble of the new constitution. The whole emerging system was strongly influenced by the motivation not to provide the aristocracy with any opportunities to dominate the political system-hence the option for unicameralism.

Probably the most important philosophical godfather of the new constitution was Jean Jacques Rousseau, with his Social Contract, first published in 1762. In it, Rousseau had established popular sovereignty as the basis for modern democratic legitimacy (Rosanvallon 1992: 26). Among other statements, Rousseau declared that "The legislative power belongs to the people, and can belong to it alone" (bk. 3, chap. 12: "How the Sovereign Authority Maintains Itself"). With regard to the law, Rousseau highlights the same principle: "Every law the people have not ratified in person is null and void-is, in fact, not a law" (bk. 3, chap. 15: "Deputies or Representatives").

Central to the establishment of "one person, one vote" was Rousseau's work on the general will. Indeed, Rousseau's thinking on this issue provided the blueprint for article 6 of the Declaration of the Rights of Man and the Citizen. It reads:

The law is the expression of the general will. All citizens have the right to contribute personally, or through their representatives, to its formation. It must be the same for all, whether it protects or punishes. All citizens, being equal in its eyes, are equally admissible to all public dignities, positions, and employments, according to their capacities, and without any other distinction than that of their virtues and their talents.

This focus on the equality of all individuals, as long as they were citizens, and the aversion to any kind of special interests, groups, and associations 
still characterizes the French republic today. This chapter examines some of the implications, as well as shortcomings, of this republican tradition. My focus is on two specific shortcomings: first, the very foundational problem of who counts as a Man, and secondly, the related problem of how such a tradition is translated into contemporary politics. This chapter will demonstrate that nonwhites were not considered Man by the French metropolitan forces that dominated the political scene in revolutionary France. From the very beginning, the supposed radicalism of the French Revolution was thus severely flawed. More than universal principles, it expressed Western white principles that were, in addition, further limited by their gender bias. I further argue that this ambivalence is still characteristic of contemporary France, so that the supposedly neutral framework of "one man, one vote" serves the purpose of perpetuating privilege while prolonging second-class status for nonwhites. The relation between defending privilege while producing exclusion is indeed dialectical in that one constitutes the other.

Methodologically, the best place to unveil the mechanisms that constitute privilege through exclusion and second-class citizenship are at the very margins of the French polity - there where the regime ran thin. Before delving into the politics of contemporary France, I will thus explore the situations in some of the French colonies.

\section{COLONIES: WHERE LIBERALISM HITS THE FAN}

After the fall of the Ottoman Empire in 1918, France assumed a mandate of what today is Syria and Lebanon, which lasted until 1946. France had indeed acquired experience in the "Orient" after Napoleon's conquests of Egypt in 1798 - and was thus deemed well suited by the League of Nations for this task. During that time, "the French established a tacit pecking order of access to state jobs and other economic benefits. In Lebanon, Christians obtained a disproportionate number of civil service jobs, despite the constitution's promise of equitable access" (Thompson 2000: 81). Once it became clear, through the 1932 census, that the French colonial administration was biased against Muslims and for Christians, the French did what they still do to this day: they stopped collecting ethnic and religious data in the census (Thompson 2000: 82).

One can observe similar contradictions in other corners of the French colonial empire. There, as elsewhere in the colonized world, racism was integral to domination, as Ann Stoler has so vividly explained when stating, 
"Racism is an inherent product of the colonial encounter, fundamental to an otherwise illegitimate access to property and power" (Stoler 2002: 24).

In the French Caribbean, for example, revolting slaves did not find the sympathy and support from the revolutionary champions of fraternité and égalité back in the colonial motherland. Even Robespierre, as radical as he was, did not push for the de facto emancipation of slaves - even if he favored it in theory (James 1938: 59).

To the contrary, such influential public figures as Condorcet, while favoring abolition in theory, argued for a gradual investment with citizenship rights, because at the time of the French Revolution, the "stupidity contracted through slavery by the corruption of their morals (the necessary result of their masters' influence), the slaves of the European colonies have become incapable of fulfilling the duties of free men" (Condorcet, quoted in Dubois 2004: 181).

When emancipation was proclaimed in Haiti in 1794, after the slave revolt, French colonial administrators sought for ways to block the full political emancipation of blacks and instead proposed a gradual transition that would not endanger the economic structure of the island (Dubois 2004: 183).

In Haiti, when nonwhites raised the banner of liberty, they were quickly dealt with. So in 1790, when "Lacombe, a Mulatto, claimed for his people [mulattos, not blacks] social and political rights. The whites of Le Cap hanged him on the spot" (James 1938: 49).

Many similar stories are found in the classic study of the Haitian Revolution by C.L.R. James. There is the case of M. de Baudière, a French colonial administrator in Haiti, who also in 1790 proposed a "moderate petition for some Mulattoes seeking to improve their status" (James 1938: 49). He was lynched by the local whites, his body "shamefully mutilated" (James 1938: 49).

Back in Paris, where the taking of the Bastille and the passing of the Declaration of the Rights of Man and the Citizen inspired the masses, it quickly became clear that blacks and mulattoes were not included among the Men and Citizens. Abbé Grégoire, spokesman for the "Friends of the Negro," as well as a member of the French National Assembly, proposed that the declaration thus gave mulattoes (not blacks!) the right to vote. To this, "a San Domingo deputy protested. Another deputy moved that the discussion be closed. De Lameth, the same who had chirped so noisily three months before, agreed that Gregoire's 'indiscreet proposal' should not be discussed, and the House decided not to discuss it" (James 1938: 55). By denying political rights to mulattoes and not even considering blacks, the French 
Declaration of the Rights of Man and the Citizen indeed made nonwhites nonhumans - a point stressed by Frantz Fanon in 1956. In his resignation letter to the French colonial minister in Algeria, Fanon wrote: "What is the status of Algeria? A systemized de-humanization" (Fanon 1970: 63).

Indeed, as C.L.R. James (1938) shows, Haiti could only achieve emancipation for its slaves by breaking with France. Napoleon had sent his own brother-in-law, Charles Leclerc, to Haiti to restore slavery and bring Haiti back to France, so that it could continue to produce the riches France so desperately wanted. The biggest army Napoleon had ever sent abroad was given the mission to reinstate slavery for the land of universal freedom and brotherhood. However, almost all of the 34,000 French soldiers found their death in Haiti.

Clearly, as Etienne Balibar (2004) has argued, the European Enlightenment not only accepted racism-it indeed constituted it. To claim cultural heights for Europeans rested on the previous establishment of civilizational hierarchies that were profoundly racialized. This view assumed that Europeans had climbed to the cultural heights that gave them specific rights and entitlements, whereas non-Europeans had not achieved this stage yet and thus lacked the intellectual, cultural, and hence civilizational qualities that provided the groundwork on which liberalism rested. Since Kant, this groundwork was comprised of rational, autonomous individuals whose reason and intellectual autonomy allowed them to decide for themselves, and whose individual preferences could then be amassed and translated into collective decisions (Rosanvallon 1992). In particular, Africans provided the necessary contrast to these European achievements (Eze 2008). Africans were classified by European analysts as not rational or autonomous enough to have their voices heard and considered. They instead needed tutelage. As Frantz Fanon has argued, the colonized were part of the realm of dehumanized *non-being (Fanon 1967: 10).

The constitutive function of black backwardness as the measure for white advancement, which translated into white rights and black obligations, found expression not just in the French First Republic. In the Second Republic, after slavery was abolished again (in 1848) and blacks obtained formal rights, Antillean social rights were restricted and labor coercion instituted (Blackburn 1988). Indeed, after slaves in Guadeloupe, Martinique, Guyana, and Réunion declared their freedom, the National Assembly in Paris voted not to facilitate their integration, but to compensate their former masters (Blackburn 1988: 501).

When the Second Republic embraced industrial production in the form of usines centrales for the massive industrial production of sugar in 
the Caribbean, it searched for a way to force the newly freed blacks to fuel these new, emerging machines-a task not easily achieved during the short-lived Second Republic. When the republic gave way to the Second Empire, "the Bonapartiste regime endeared itself to the planters and sugar companies by taking immediate and vigorous measures to ensure a larger and more disciplined labour force. In February 1852 an imperial edict suppressed all colonial representation and self-government; Guadeloupe's Le Progrès had already been banned. Draconian labour legislation was introduced. Every adult was obliged to carry a livret with details of employment and residence; those failing to comply could be subjected to penal labour. Subsequent regulations stipulated that those occupying plantation lands should render labour services to the planters, for which they might receive nominal payment" (Blackburn 1988: 502f).

According to Blackburn, "The slave had been forced to work by the whip; the ex-slave was forced into an unequal contract by the need to prove gainful occupation or to pay a capitation tax" (Blackburn 1988: 503). Indeed, bonded laborers for Senegal soon replaced the former slaves in the French Caribbean. In 1852, such bonded labor contracts were allowed by imperial decree. This regime operated until 1860, bringing a total of 16,000 Africans to the French Caribbean (Blackburn 1988: 503). Even though African indentured labor was ended in 1860 s, "some 77,000 Indians, 1,300 Chinese and 500 Vietnamese were introduced to the French Antilles"-all as indentured, that is, unfree, laborers and serfs (Blackburn 1988: 503).

Then, under the Third Republic (1870-1940), "the Antillean people's rights were nominally reinstated, even as they were also subject to an authoritarian colonial administration that governed a racially organized society. During the century following emancipation, rationalized bureaucracy, modern agro-industrial production, and republican colonialism became interdependent" (Wilder 2004: 37).

In one way or another, postrevolutionary France used nonwhite colonials and postcolonials to construct economic power, which was then used to justify the claim of high cultural, intellectual, and civilizational standing for themselves. Indeed, this hierarchy became so ingrained in the French Selbstverstaendniss, the way of thinking about oneself, that it arguably still informs French nationalism and mainstream representation. To this day, as the next section will demonstrate, the condition for integration into the French mainstream is to assimilate, that is, to become French, which easily translates into climbing up to the cultural heights of the French. As Tyler Stovall and Georges Van den Abbeele explain in the introduction to their 
French Civilization and Its Discontents (2003), "No proponents of these missions of French civilization ever expected that cultural exchange to be in any way bidirectional. France's 'missions,' forged by the Jacobin heritage of the Revolution, have seemingly always understood its 'universalism' to be coterminous with the assimilation of specifically French identity and its republican values" (Stovall and Abbeele 2003: 4). For the French, their mission civilisatrice was to make the world under their rule more French. Only then could they be admitted as equals. The problem, since the very beginning of French colonialism, was and continued to be that some people and groups were deemed unassimilable. The same authors just quoted explain: "In practice, though, especially that concretized under colonial rule, limits were drawn with some folks considered worthy of being civilized while others were termed 'unassimilable' and doomed to never-ending barbarism" (Stovall and Abbeele 2003: 5).

Under colonial rule, this distinction translated into a classification of natives into "indigène" and "assimilé," with different institutions and treatments for each. For Gary Wilder (2005), such a bifurcated system bore several inherent contradictions, namely, "socioeconomic individualism without juridico-political individuality, social development without civil society, citizenship without culture, nationality without citizenship" (Wilder 2005: 5). After decolonization, and with the onset of migration from the former colonies to France, this distinction carried over to a classification of first- and second-class citizens. In today's reality, as Pap Ndiaye (2008) explains, racism comes in many forms, and even if the cruder form of biologically determined racism was dismantled after the Second World War, it has survived in the form of a discrete, yet very real colonizing mission and a very dominant paternalism (Ndiaye 2008: 428).

Liberalism, as coined by the French Revolution, thus bears an inherent contradiction. On one hand, it declares itself "universal" while really only reflecting a particular French-European experience, which becomes evident in its differentiated evaluation of different civilizations, where their own is "naturally" the one superior to all the others, which hence need to be "civilized" (Chakrabarty 2000). On the other hand, it does not even live up to the very mission it declares, as it rejects some groups and cultures as outright "unassimilable," hence justifying their exclusion from a regime of French rights. Both these strategies reveal the deep bias and the inherent contradictions of the kind of European liberalism emerging during the eighteenth century in Europe. Uday Singh Mehta (1999) has highlighted this contradiction for the British case when explaining that liberalism and empire were indeed linked. According to Mehta, 
The historian in James Mill, the legislator in Bentham, the educator in Macaulay, and the apostle of progress and individuality in J.S. Mill, all, I believe, fail in the challenge posed by the unfamiliar; because when faced with it they do no more than "repeat," presume on, and assert (this where power becomes relevant) the familiar structures of the generalities that inform the reasonable, the useful, the knowledgeable, and the progressive. These generalities constitute the ground of a cosmopolitanism because in a single glance and without having experienced any of it, they make it possible to compare and classify the world. But that glance is braided with the urge to dominate the world, because the language of those comparisons is not neutral and cannot avoid notions of superiority and inferiority, backward and progressive, and higher and lower. (Mehta 1999: 20)

Similar exercises to deconstruct the great European thinkers of liberalism and enlightenment, such as Hegel and Kant, render similar results, revealing deep Eurocentric bias (Dussel 1993). However, Mehta (1999) concludes, and I agree with this assessment, that

[The] point is not that the existence of the empire and the political thought or even more specifically the liberal thought that emerged concurrently with it were obviously in contradiction. That claim is neither obvious, nor, I believe, ultimately true. In any case the language of contradictions is too precise an instrument to say anything of interest about generalities that range across centuries and involve the complicated intersections of ideas and practices, not to mention the different logics of domestic and international imperatives. Moreover, contradictions, if they do exist, do not close the space on the complexities that emerge from the extended link between liberalism and empire. They should be taken as an invitation to that space. (Mehta 1999: 7)

This space between liberalism and empire (or even the one between republicanism and racism) indeed constitutes the most fruitful unit of analysis for a critical examination of democracy and citizenship, because it reveals the profound bias of the European tradition and the mutually constitutive relationship of citizenship and exclusion. As Dipesh Chakrabarty has argued with Ranajit Guha, "The European bourgeoisie . . made its own interests look and feel like the interests of all" (Chakrabarty 2000: 15). The implications of such a politics are far-reaching and are only beginning to be unveiled. They force us to take a closer look at history, as well as to reexamine our own disciplines and the ways we approach reality (Rodriguez, Boatcă, and Costa 2010; Boatcă 2010; Lander 2002; Mignolo 2008). 
In contemporary France, assimilation still provides the only way to find acceptance among white, mainstream Frenchmen and their polity. Assimilation, however, is not easily achieved, even if most immigrants seek it. On one hand, nonwhite skin color resists easy assimilation; on the other, religious beliefs and the symbols they come with seem too costly to simply give up in order to find acceptance. The result among all those who seek integration, acceptance, and even assimilation, but have not been able to achieve any of them, is often one of frustration and resignation. Among the youth, especially those born in France, this frustration has led to protests of different forms - some nonviolent, others less so. However, French official ways are apparently stubborn. In February 2004, the French parliament outlawed the use of religious symbols in public schools, forcing Muslim girls to unveil themselves. After the breakout of minority youth riots in early November 2005, Prime Minister Villepin asserted: "France is not a country like others. It will never accept that citizens live separately, with different opportunities and with unequal futures."

The way the French state seeks to ensure equal opportunities is guided by its commitment to the republican ideas of citoyenneté and intégration, which point to assimilation as the only way to integrate immigrants and nontraditional citizens into the nation. The core of this philosophy is to not recognize differences among French citizens, and to apply color-blind public policies to ensure equal opportunity.

However, the assertion of the French prime minister was in stark contrast to a French reality that has been depicted by many as increasingly separate, where people of different ethnic backgrounds encounter very different opportunities and face highly disparate futures. ${ }^{2}$ France has become a showcase and example for a more dominant European policy of not recognizing ethnic groups and minorities, and focusing on assimilation as the main, and indeed only way to integrate immigrants. Officially, once a citizen, the French state does not take into account any group-specific characteristics that de facto set the citizenry apart, such as ethnicity, religion, or gender. The French state therefore insists on a form of radical individualism that is anchored in political liberalism and classical republicanism. This model is dominant all over continental Europe, and the importance of understanding the French way of officially denying the very existence of minorities, therefore, extrapolates beyond the borders of the Fifth Republic, where it originated. 
In real life, the distinction of insider/outsider that regulates national belonging and the distribution of rights is negotiated through the construction of a racialized conception of community. Nationalist political groups rediscover and disseminate a myth of "purity," detecting "foreign" elements that "contaminate" the national body. Thus, whereas French political elites insist on not officially recognizing any minorities within the national body, cultural, ethnic, and religious differences are routinely recognized in everyday interactions, and they are extremely consequential.

The French citizenry is in itself biologically, culturally, religiously, and ethnically heterogeneous and has indeed always been so. This implies that nonwhites are not necessarily foreigners and immigrants. To present and frame them as such is at the very core of the problem-or more precisely, it constitutes them as a problem. This framing is, however, very prevalent in France as elsewhere in Europe. In a very telling interview broadcast in October 2005 on prime-time French TV, Hélène Carrère d'Encausse, a French historian and distinguished member of the Académie française, when asked about how to understand the riots of black youth in French banlieues, stated: "I am not surprised at all: how could young Blacks, coming directly from their African village, adapt to the French way of life?" (Millot 2005).

There is, however, no reason to believe that the black youth who took the streets in France in 2005 and thereafter were foreigners-let alone immigrants. To the contrary, there is every reason to believe that instead, the situation of the two boys electrocuted while running from the police after playing soccer on October 7, 2005, was typical: both Bouna and Zyed were born in France. Generally, it takes a long history of broken promises, frustrated hope, failed help, and discouraging experience in one's own country-not the country of others - to produce the kind of protests the world has been witnessing in France (Keaton 2009). However, the exact backgrounds of French minorities are not known, because official population surveys do not account for them, following the French tradition so well established in such places as Syria and Lebanon. The only data available come from nongovernmental organizations and are thus limited in their degree of representativeness. They are still informative.

In a survey conducted in 2007 by SOFREs, "the most renowned and largest market-research firm in France" (Tin 2008: 36), a total of 3.86 percent of adults interviewed self-declared "black." Of those, 56 percent declared that they had experienced racism in their everyday lives. ${ }^{3}$ Research has further demonstrated that young blacks (classified in the available surveys as second-generation Maghrebins and sub-Saharan Africans) are 2.5 times as likely to be unemployed than their white counterparts, which means that 
their unemployment rates hover around 20 percent! Although nonwhites also drop out of school more often than whites, their difficulties in finding jobs remain, even when compared to whites with the same qualifications (Silberman, Alba, and Fournier 2007).

Similarly, such authors as Philippe Bernard (2004) and Sylvie Zappi (2004) have demonstrated that nonwhite French graduates from French elite universities were 25 percent less likely to find jobs in the private sector compared to their white colleagues with the same qualifications, and that France has never appointed a black ambassador to one of its 156 embassies-even though there are plenty of well-prepared black diplomacy graduates.

Hence, in the words of Pap Ndiaye (2008), being black in France is an "objective social handicap" (Ndiaye 2008: 430), and the de facto effect of discriminatory practices is one of racialization. According to Ndiaye (2008), "There therefore exists a black minority in France insofar as there is a group of people considered black and united by this very experience, which constitutes a tenuous, yet indisputable link. This link is not necessarily the foundation of a racialized identity, but it recognizes the shared destiny of being considered black, no matter the subtle diversity of the chosen identities" (Ndiaye 2008: 65, my translation). Patrick Lozès, former president of the French Representative Council of Black Associations, an umbrella organization for black associations in France (Le Cran), and candidate for the 2012 French presidency, confirmed this assessment. In his experience, "Blacks in France are not full citizens . . . they are invisible 'glass citizens,' because not even their numbers are fully known." "The research conducted by Le Cran showed that 81 percent of blacks in France were indeed French citizens; the widespread perception, however, is that most blacks in France are foreigners. "They cannot go back anywhere- their country is here" (Patrick Lozès, interview June 20, 2011).

The racist and exclusionary practices responsible for this situation are not hard to decipher as anxious responses of traditional, white residents towards a changing environment, fanned by nativist political elites that have much to gain from blaming immigrants and nonwhites for complex socioeconomic problems (Giry 2006). Indeed, as Vincent Geisser has demonstrated in the case of Muslims, "Islamophobia in France, unlike elsewhere in Europe, is largely an intellectual phenomenon driven by elites, and it stems less from insecurity than from racialist ideology" (quoted in Giry 2006: 92). The public debates about the accusation of Vincent Geisser, a French researcher accused in 2009 by the "defense security officer" of the National Center for Scientific Research (CNRS) for holding "too favorable opinions of Muslims" further testified to the active involvement of political elites in 
the framing of nonwhites as non-belonging foreigners and intruders who do not deserve the same treatment and rights as traditional white citizens. However, the black presence in France started in the eighteenth century, the great century of the slave trade. By royal decree, once in France, slaves had to be liberated and instructed in a craft. Already in the seventeenth century, there was thus a bifurcated treatment of blacks. Whereas those residing in the colonies fell under the 1685 Code Noir, those brought to and residing in mainland France had access to certain rights and privileges, and slavery was thus actively fought in mainland France. Free blacks did fall under some restrictions, such as the ban to marry, in order to avoid the proliferation of mixed races. "In December of 1738, a royal decree limits the stay of slaves to the learning of a craft and a maximum time of three years" (Ndiaye 2008: 134, my translation). As early as 1770, some 5,000 blacks resided in France, out of a total population of 20 million (Ndiaye 2008: 134f).

Hence, as Pap Ndiaye (2008) has argued, "Paris has been a black capital, where Africans, Caribbeans, Guyanese, and African Americans have mingled since the 1920s and where an encounter between the universally humane and the particular black has been practiced, with all its tensions and contradictions, and at times its tears" (Ndiaye 2008: 427f, my translation). The depiction of nonwhites as intruders and immigrants is thus not correct, and instead of describing a reality, rather provides a framework that permits the allocation of blame. "Foreigners" and "immigrants" are held responsible for most of the contemporary problems France faces, even though the great majority of them are indeed French citizens, so that this blame can easily be translated into blaming nonwhites and non-Christians (Patrick Lozès, interview June 20, 2011).

However, as noted above, white French citizens effectively benefit from the exclusion of nonwhites-especially in the job market, where high unemployment also affects them. In such crucial institutions as the National Assembly, the diplomatic corps, the army, or even in local government bodies, black citizens are either severely underrepresented or entirely absent (Lozès, interview 2011). Housing is another central area where discrimination is widely practiced, negatively affecting nonwhite citizens while positively furthering the chances of white citizens in such competitive housing markets as those in Paris. "Some blacks simply cannot find apartments and are thus forced to live permanently in hostels, where they are exposed to all kinds of dangers, or they are forced to live in apartments that pose risks to their health, due to contaminated walls and pipes" (Lozès, interview 2011).

According to Patrick Lozès, to achieve justice, the crafting of public 
policies that ensure equity is crucial, because "it is all about power, and nobody wants to share power" (Lozès, interview 2011).

Given the evidence of discrimination and unequal treatment affecting the French citizenry, depending on their skin color and religion, how can we explain that the French state insists on not providing statistics that capture these inequalities? Established practices around the job market provide a first clue: It is a common practice in France, as well as elsewhere in Europe, that curricula vitae need to contain information about the age of the applicant, as well as a photo. The black French citizens I interviewed in 2007 all had experienced similar situations when applying for a job. Their candidacy advanced up to the moment when it became obvious that they were black.

The statement of one black female interviewee, age twenty-eight, holding a university degree, born in France and a French citizen, was typical. She explains (after my question regarding situations where racism is most influential): "At work, especially when you apply for a job. At job interviews, I would always be asked where I was from. I am French, but to them, it doesn't appear that way." 5

On average, the black French citizens I interviewed in 2007, all of whom held university degrees and were French citizens, took about three years to finally find a job. In most cases, they found jobs that did not meet their expectations - a finding confirmed by more systematic research (Simon 2003).

The French state thus demands, or at least tolerates the fact that job applicants need to give evidence of their skin color when applying for jobs, fully aware that this will significantly impact their chances to find a job. In other words, French political elites and the state they command are aware that traditional white French citizens routinely discriminate against nonwhites and non-Christians, a conclusion that is further evidenced by the long history of half-hearted and thus ineffective measures taken by the French government to at least formally address this issue (Kiwan 2007). But those same elites avoid taking any concrete and effective action to counteract this situation with reference to the ideals of universalism, laicism, and republicanism, although all of these ideals were formulated precisely to ensure equality, brotherhood, and liberty. So why have political elites in France not acted more decisively to ensure the quality of their democracy and the upholding of the high principles it represents? The most plausible answer, it appears, is that they do not want to. The conclusion reached by Louis-Georges Tin, black activist and founder of Le Cran, seems the most plausible: 
I must note that the fierce adversaries of communities, as a matter of fact, were not against communities as such; they were against some communities: Arab-Muslims, Jews, and homosexuals. . . . No one criticizes the sixteenth arrondissement in Paris, a bourgeois community which also has its particular habits, mores, and customs. No one would dream of criticizing the traditional communities, professional communities, and the Catholic communities. (Tin 2008: 38)

Prohibiting the excluded from using cultural, ethnic, and religious criteria to address inequalities, while at the same time allowing employers to use ethnic criteria in their hiring practices, reveals the deep bias with which political elites address this issue. French political elites know about the discriminatory practices that victimize a part of the French citizenry, yet they do not act decisively to resolve them. Instead, they hold onto a mere rhetoric of universalism, even though the aim of universalism is to ensure equal rights for all. French citizenship has, as a consequence of persistent discrimination, become racialized and divided. Whereas traditional, white citizens insist on their citizenship rights, thus treating them as assets and entitlements, ethnicized nontraditional citizens have become second-class citizens, who are not allowed to experience the full extent of the role of being a citizen. To them, citizenship is not a set of entitlements, but has remained an unfulfilled promise.

It is not surprising that people seek to defend privilege, especially if unmerited, when it promises to secure concrete and very important advantages - for example, in a very competitive job market. Under such conditions, whiteness serves as an important capital, bestowing extra symbolic capital onto its bearer (Reiter 2010). It is, however, the responsibility of political elites and state apparatuses to check these tendencies and enact policies that aim at ensuring equal opportunities. That is the core of the universalist idea. Instead, French political elites are assisting white citizens to defend their privileges, thus revealing profound double standards. If the French state were indeed so sternly opposed to any form of particularism, then the ethnic marking of applicants on their curricula should be illegal, especially considering its highly consequential effects on (universalist) equal opportunities. Racist bias in hiring would also have to be addressed in other ways in order to ensure equal chances-for example, by enacting quotas. Furthermore, if state elites were really committed to achieving universal equality, they would not rob those negatively affected by discriminatory practices of the means to address them. They would allow a diagnosis of the current situation of the French citizenry that takes into account inequalities, 
in the form of color-conscious censuses. French political elites, however, have not acted decisively to effectively counteract the racist practices of traditional, white citizens. This reluctance can only be explained by remembering the benefits that political elites and their electorate reap from the current situation: it provides the white majority with a competitive advantage in the job market, and it allows state elites to escape scrutiny and shields them from being held responsible for the wide array of social problems facing French society by blaming "others."

As such, the French case highlights the structural impediments and perverse incentives created and maintained under majority rule whenever political cleavages reflect ethnic differences. Under such conditions, white majorities have no incentives to extend substantive citizenship to nonwhite minorities, as access to substantive citizenship is perceived by these majorities as a zero-sum game, where extending access implies losing privileges that are perceived not as rights, but as entitlements. Political elites, in turn, have no incentives to truly represent the interests of minorities, even less so when the representation of their interests is perceived as hurting the interests of the majority, whose votes they need, after all. More than in racial hatred, many of the problems around successful integration of minorities in France are thus rooted in the asset character of substantive citizenship, which provides structural incentives for the political mobilization of majorities against structural minorities. ${ }^{6}$ This phenomenon is made worse by the impossibility of rendering ethnicity and religion politically unproblematic by simply ignoring them, as they tend not to be ignored in everyday interactions.

Under such conditions, black scholar-activist Pap Ndiaye (2008) expresses sadness in the face of so many dreams and hopes crushed. Seeking to capture the aspirations of black French formal citizens, Ndiaye explains, "We want to be at the same time black and French, without being considered suspicious, strange, or merely tolerated as a temporary problem waiting to be assimilated away. We want to be invisible in our social lives so that the distortions and mishaps that affect us as blacks are effectively reduced. But we want to be visible when it comes to our black cultural identities, our precious and unique contributions to the French society and culture" (Ndiaye 2008: 426, my translation). 


\section{CONCLUSION: THE DISCRIMINATORY DIMENSIONS OF CIVIC BONDS}

The case of France allows us to discern several causally relevant mechanisms producing exclusion and second-class citizenship. The analysis of France demonstrates that racism can survive and indeed articulate itself with civicness. The French system is such that it first encourages non-French to become French - only to classify some people and groups as unassimilable. The frustration that such a system produces among those so classified can hardly be overstated - and the vehemence of youth protests held by minorities since the beginning of the 2000s gives ample evidence of this frustration. It is not just unfair, but wickedly racist to first declare that all can become French-except you.

Practicing this sort of schizophrenic classifying of human beings and groups, while at the same time ensuring that they have no means of classifying themselves (which is achieved by not providing any official numbers on the situation of minorities), the French state reveals the deep contradictions of its liberal, republican foundation. In fact, the republican ideal of selfgovernance, as expressed so radically by Rousseau, never meant to include others besides white European males. Worse, it used nonwhites to construct the very position from which it proclaimed its own superiority. By doing so, it also evidenced the hollowness of the classical Western liberal tradition on which this discourse ultimately rested. To govern oneself as a collective, individuals had to be rational and autonomous - but according to the thinkers developing this idea, not all men were. Women certainly were not, and neither were all those whose poverty or divergent societal and developmental models pushed them down the civilizational ladder, according to the monodimensional evaluation model of the European classifiers. In fact, white European males found only themselves worthy of self-governance and democracy. The rest of the world-black, brown, or yellow as classified during colonial times - they found lacking, and at best able to learn Western ways after long and arduous work and training. Some, especially Africans, were deemed unassimilable. To say so was necessary, because how else to enslave, dominate, and control them, treating them as tools, things, and machines-radically dehumanizing them? What was called "universalism" thus reveals in the treatment of nonwhites and non-Christians its profound particularism and bias. The high talk of liberalism, republicanism, equality, brotherhood, and justice was nothing more than that: talk. 


\section{CHAPTER 6}

\section{The Postcolonial Within Portugal, White and European}

It is part of the organic essence of the Portuguese Nation to carry out the historical function of colonizing and owning overseas dominions and civilizing indigenous populations. -ARTICLE 2 OF THE COLONIAL ACT, DECREE NO. 18.570, 8 JULY 1930

In this chapter, I analyze Portugal's negotiations around the issues of citizenship, belonging, and rights. Portugal, again, is a very telling and crucial case. It represents several empirical/historical phenomena. For one thing, as a European Union member, Portugal is a typical European case. Given Portugal's fairly recent admission to the EU and its position at the margin, geographically as well as in terms of importance and influence, an analysis of Portugal allows us to untwine the rather complex issues involved in joining the "Fortress Europe" (Gordon 1982). But Portugal as a case has more to offer. Due to its long colonial history as the first European power to set out to conquer the rest of the world, and the last European country to let go of its former colonies (in 1974), Portugal is a showcase of the colonial entanglements that characterize other European former colonial powers as well. Portugal is typical in its "French" approach (described above) of focusing solely on assimilation as the sine qua non condition for the integration of nonwhite and non-Christian others, and thus represents a broader European integration regime. What stands out in Portugal, however, is the very clear way in which the state is involved in forming, enforcing, regulating, and policing this regime. It is precisely this strong and 
clearly observable state involvement in the ways of Portuguese belonging and not-belonging that provides one of the strongest rationales for including Portugal in this study. To be certain, all states are directly involved in the ways that issues of citizenship, belonging, foreigners, immigrants, and integration are framed and discussed in their respective societies. In Portugal, however, this involvement is more clearly observable than elsewhere. Here, not only is one able to observe and analyze the direct involvement of the state in the framing of a common sense of who is rightly Portuguese and who is not-but also one can observe how other elite-dominated central state institutions, particularly universities, are recruited in this effort. Portuguese universities, I shall demonstrate in this chapter, have become accomplices in the process of framing nonwhite Portuguese citizens as foreigners and immigrants.

\section{THE RE-ENGINEERING OF NATIONAL BELONGING}

Portugal has a long history as a nation-state, reaching all the way back to 1249. National unity and the early creation of a nation-state, which allowed for the systematic collection of taxes and extraction of profit, allowed the Portuguese crown to invest in overseas adventures before any other European nation had the means to do so. Portugal ventured to, and conquered, parts of Africa as early as the early fifteenth century, successfully taking North African ports, such as Ceuta, in 1415. Sponsored by Henry the Navigator, Portugal, a small country with barely one million inhabitants, became the biggest trans-maritime empire of the world, with possessions in Africa, India, China, the Pacific, and, after 1500, the Americas.

Much has been said and written about the Portuguese propensity to mingle and mix with native populations, contributing to a vast mixed population wherever they went. For the current purpose, this is not a relevant discussion. However, it is relevant to note that the Portuguese male conquerors lacked the numbers to effectively populate those regions they had conquered, thus resorting to the production of mixed offspring as a means to guarantee control of the vast empire. This was achieved by making their mixed offspring the overseers and indirect rulers over natives. Portugal thus created its own form of indirect rule-one relying on the politics of demographics. It also used colonized people from one place to control colonized people from another, typically in such a way as to use lighter-skinned people to control darker-skinned groups, hence creating a sophisticated, and 
wicked, scheme of colorism throughout its empire. Indians from Goa were thus used to control Mozambicans; Cape Verdeans became indirect rulers over Angolans, the people of Guinea-Bissau, and the people of São Tomé and Principe (Leonard 2000).

The Portuguese empire lasted longer than any other modern European empire-from the mid-fifteenth century all the way to 1974, when the empire finally crumbled from within. During the last years of Portuguese colonialism, the Portuguese regime under Salazar and Caetano resorted to very consequential strategies in order to keep the empire intact. They extended Portuguese nationalism to include the colonies, thus boldly declaring that Portugal had no colonies. Instead, they argued, such places as Angola and Cape Verde were one with Portugal.

Such strategic maneuvering, of course, came with a price. Until 1961, the price consisted of offering Portuguese passports to all those who worked for the Portuguese colonial state, as well as all those who could pass the "civilizational" test as spelled out by the indigenato legal code, which regulated who was to be considered civilized and who remained barbaric. By adopting the customs of the colonizers, some natives could thus gain access to the right of Portuguese citizenship. Lastly, all those fighting and willing to die for the Portuguese motherland during the long wars of independence were also given, as reward, the privilege of Portuguese citizenship.

After independence for most (not all) Portuguese colonies finally arrived, many of those attached to the Portuguese state in one way or another moved to Portugal, either because they had no other choice, or because they hoped to cash in on the benefits that lifelong sacrifice for Portugal had earned them. With them came some 800,000 "returners"-that is, Africans who had held onto their privileged status of being colonizers while living, often for generations, in the colonies. Their passports were written on their skins, as their whiteness legitimized them as being "truly" Portuguese.

Faced with such a large legacy of some five hundred years of colonizing the world and declaring that all of it was, in fact, part of Portugal, the country had to rethink what it meant to be Portuguese. This necessity became even more urgent when the country applied for membership in the European Union, in the early 1980s. To join Europe with such an expansive notion of who one was, and thus who could also benefit from European membership was impossible and would have made Portuguese membership impossible. After all, it would have meant opening the gates of Europe to parts of Africa and Asia.

Whereas from the European perspective, Portuguese admission was a question of cutting back the contours of who counted as "Portuguese," for 
the Portuguese themselves, there was even more at stake. Experts as they were on measuring and judging the level of civilizational progress that would make one deserving of the rights and privileges of exclusive membership, they now had to pass the civilizational tests for being considered truly European and thus worthy to join such an elite club as the one in which France, England, and Germany were important members. All of a sudden, the long history of mixedness, of exposure and openness to Africa that had produced in the Portuguese the supposed hybridity that made them the champions of cordial race relations - this legacy now cast a dark shadow over their own situation. In the eyes of many European observers, but even more so in their own eyes, they were indeed not really white, not really pure, European, and civilized. To some of their former colonies - particularly Brazil, which had gained independence much earlier-they were even "funny," entertaining, backward oddities; the poor cousins who lived in a backward peasant country, small and unimportant, speaking with an anachronistic accent.

For the Portuguese elites-political, intellectual, and economic -in a country where there was much overlap among those categories, the nation thus had to be purified and purged of its hybridity and mixedness; sanitized and transformed into a modern, white, civilized, and thus truly European country (Fikes 2009). Starting in the 1980s, Portugal thus became a showcase of national re-engineering and an example of how to redefine and remold a whole country. Nowhere else, to my knowledge, can this process be observed in more detail and clarity than in Portugal, thus making it an ideal case for such a Foucauldian analysis.

\section{NONWHITES INTO FOREIGNERS}

Portuguese society is increasingly heterogeneous-although there are no data on how heterogeneous its population truly is, as the Portuguese state follows the French model of not differentiating among its citizens. However, cities such as Lisbon count on a significant population of nonwhite citizens who go to school with, and compete for jobs against, the dominant white population. After examining the role of state elites in the creation and maintenance of a racist common sense that leads to racialized conceptions of first- and second-class citizenship, the case of Portugal permits us to shed light on the implication of academia in the maintenance of a racist and exclusionary common sense, which frames nonwhites as foreigners and immigrants while deciding upon who "fits in" based on ethnic background. 
I shall present two arguments to elucidate this phenomenon: first, the fact that there are almost no studies on blacks in Portugal, despite their visibility in cities like Lisbon and Porto; and second, the fact that some immigrants are much more welcome and taken care of than others, namely, those labeled "home-comers" (retornados), an attribute with strong racial undertones.

When searching for books and articles about blacks in Portugal, or on the situation of minorities in that country, one is hard pressed, as there are almost none. ${ }^{1}$ Instead, it is very common to read that "Portugal is a fundamentally homogeneous country in terms of ethnicity and language, and also as regards religious faith" (Freire 2007: 208). This contradicts all empirical experience when in Lisbon, and we do know from research that "legally settled foreigners represent around 5 percent of the resident population" (Marques, Valente Rosa, and Martins 2007: 1149). Furthermore, research on education, such as that undertaken by Marques, Rosa, and Martins (2007), who in 2004 conducted a case study in the poor municipality of Oeiras, Greater Lisbon, allows us to grasp the degree of heterogeneity that characterizes contemporary Lisbon society. Marques et al. find that among their sample of Oeiras students age fourteen to twenty-four, "44.3 per cent [were] . . . children of immigrants" (Marques, Valente Rosa, and Martins 2007: 1156). At the same time, articles and books about immigrants abound, thus creating the false impression that Portugal has indeed an immigration problem, but not a problem of ensuring equal opportunities for its diverse citizenry.

The question arises: what kind of scholarly blindness has allowed social scientists to state that Portugal is a fundamentally homogeneous country? It appears that the lack of statistics on the presence and situation of minorities among the Portuguese citizenry has become a self-fulfilling prophecy. By focusing academic research on foreigners and immigrants while at the same time not producing any information on the mere number of minorities, let alone their socioeconomic situation, Portuguese scholars help perpetuate a common sense that says, "Portuguese citizens are white; nonwhites are foreigners and immigrants." Similar to the French case, the interest behind such maneuvering is quite evident: real problems remain unexamined and important questions unaddressed; political elites escape scrutiny by shifting the blame onto others, which allows them to continue in their malpractices; whites, perceived as "normal citizens," benefit from the bedeviling of nonwhites and reap tangible benefits.

In the case of Portugal, where funding for scholarly work in the social sciences is scarce, and almost 100 percent of funding for scientific research generally comes directly from different state agencies or from the state-owned 
Foundation for Science and Technology (FCT), it becomes clear that intellectual elites depend on state elites for the funding of their research projects. ${ }^{2}$ The fact that there are so few studies on ethnic minorities, especially blacks, in Portugal thus cannot be interpreted as a coincidence. To the contrary, the only two possible explanations for this lack are that (a) the state does not fund such studies, or (b) that Portuguese researchers do not propose any research projects about Portuguese ethnic diversity in relation to equal opportunities and the question of justice. Both possibilities seem plausible; however, the inherent conservatism and inertia of scientific research programs, favoring research projects that are within already established paradigms, clearly play a role. This scientific conservatism complicates the emergence of new research projects that are unconnected to already established truths and the methods, units of analysis, and research questions associated with them (Popper 2002; Kuhn 1996). Hence, even if state agencies are involved in consolidating a racialized common sense, scholars share in the responsibility of perpetuating the invisibility of ethnic minorities in Portuguese society, which in turn contributes to perpetuating their situation of exclusion and second-class citizenship status.

According to the extremely scarce information available, secondgeneration immigrants (a doubtful denomination in itself) fare much worse in school compared to their white counterparts. Marques et al. (2007) find that "Africans have gained the status of the most 'visible minority.' Surveys show that they are more prone to be perceived as immigrants than any other category. ... They are still the least welcome in close family relations" (Marques et al. 2007: 1149). These researchers find that "nearly three quarters of students with Cape Verdean ancestry experienced grade blockage at least once" (Marques et al. 2007: 1160). In other words, 75 percent of students with a Cape Verdean background, age fourteen to twenty-four, attending school in Oeiras, greater Lisbon, have repeated at least once before they graduate from high school!

These researchers state that "In Oeiras we found that around a third of the Portuguese students have to repeat a school year at least once, compared to 41 per cent for native-born children of immigrant parentage and 51 per cent for the foreign-born" (Marques et al. 2007: 1158). There are also extreme differences among "native-born children of immigrant parentage" and those born to traditional Portuguese residents with regard to dropping out, despite the fact that the majority of Portuguese students (77 percent, according to Marques et al.) aspire to attend university. Hortas (2008) confirms these findings, at least indirectly, when she states that "When we look at immigrant dropout/failure, we see that the rates are triple the norm in primary school, and double for the other cycles" (Hortas 2008: 423). 
The use of such extremely cumbersome designations as "native-born children of immigrant parentage" hints at the difficulties that Portuguese scholars face when discussing this issue. When reading through the available educational statistics and the research conducted in this field, it appears that what schoolchildren who face above-average dropout and repetition rates indeed share is not their legal status, but the color of their skin. They are all nonwhite, and even though Portuguese is their first language, they perform significantly worse than their white Portuguese colleagues and white EU immigrants. ${ }^{3}$ To put this clearly: white foreigners whose first language is not Portuguese by far outperform black Portuguese students whose first language is Portuguese.

The relative absence of studies about the socioeconomic situation of Portuguese minorities, especially blacks, and the cumbersome treatment and reluctance with which they are treated, if at all, together with the high profile of studies that focus on immigrants — all help consolidate the already widespread common sense that transforms black Portuguese citizens into foreigners. The statement of an interviewee illustrates this state of affairs:

I am a Portuguese citizen but at the same time I am not a Portuguese citizen. I have all the rights, but at the same time, I have none. I have even represented Portugal at international events, while I was a student. But because of my color, I am not treated as a citizen. I constantly experience discrimination at all levels: social, cultural, economic. ... I compete in the job market against Portuguese classmates that had worse grades, but they get the job. ${ }^{4}$

Who counts as a national and who does not thus has severe consequences on opportunities in France as well as in Portugal-no matter what the citizenship status. "Nationals are white," says the common sense-a common sense that obfuscates all the inequalities and injustices to which nonwhite citizens are routinely exposed, while at the same time securing privileges to white citizens, and relieving political elites of their responsibilities to ensure justice and equality among their citizenry - the cornerstones of democracy.

TIES TO THE MOTHERLAND: OF REMITTANCES AND RETURNERS

A final piece of empirical evidence of the construction of extremely biased racial regimes in Portugal is provided by the curious case of the so-called 
"home-comers" (retornados) — white African immigrants who settled in Portugal mostly between 1974 and 1975. When Portugal's African colonies achieved independence in 1974, many white colonizers ran the risk of losing their privileges and maybe even their properties and lives, and some 800,000 decided to move to Portugal. These white home-comers encountered such a willing and open Portugal that the whole experience has been widely praised as a "great success story" of integration (e.g., by Rui Pena Pires 2003). The willingness of the Portuguese society and state to accommodate these immigrants went so far as to alter a long-established legal tradition, namely, the naturalization law, which in 1981 was changed from jus solis to jus sanguini to accommodate the returning colonizers now left without a home. Since the changes of 1981, a child born to a Portuguese parent automatically becomes a Portuguese citizen, provided the parent was born in Portugal or in a territory administered by the Portuguese state. ${ }^{5}$

Since 1981, Portugal thus has extended citizenship to those able to claim Portuguese ancestry, while at the same time complicating the integration of all those who lack it. Through this maneuver, returners were not considered immigrants (Pinheiro 2008: 66). The success of this reintegration, according to Pinheiro, who quotes retornado researcher Pena Pires, one of the most respected scholars in this field, was due to the fact that "this biographical particularity of this community is not visible in Portuguese society" (Pinheiro 2008: 66). Read: they were white. Pinheiro continues: "With the retornados also came approximately 28,000 Africans, both refugees from the civil wars in Angola and Mozambique and working immigrants from all former colonies. Unlike the retornados, this African community had no special connection to Portugal or Portuguese nationality since they came from independent states" (Pinheiro 2008: 67)—no connection other than having worked for the Portuguese colonial empire and, as a consequence of betting on the wrong side, having lost a home in the newly independent African states, one might add. Indeed, a significant number of this early group of Africans in most likelihood held Portuguese passports because they had worked on the side of the colonizers, helping to control and administer the "natives," a fact that can easily be verified by interviewing this population. They just did not blend into a predominantly white society as easily, due to their own "biographical particularity." In fact, as Marques et al. (2007), explain, some of these "returners" have lived in Africa for generations. The maintenance of cultural ties to the colonial motherland has proven extremely consequential to them, so that in contemporary Portugal the divisions created under colonial rule-namely, between colonial subjects and colonizers - still plague intra- and interethnic relations (Reiter 
2008). It also seems legitimate to deduce that the dual labor market that affects the chances of African migrants and their descendants, diagnosed by Eaton (2001), can in part be explained by the relation of different African-descendant groups to the Portuguese colonial state. In an interview conducted in 2003, the president of the Lisbon-based Cape Verdean association, Ms. Alestina Tolentino, explained:

After independence, many Cape Verdeans settled in Portugal. They were Cape Verdean nationals, but they had worked for the Portuguese state in Cape Verde. As such, they had acquired certain rights, pensions, social security, and such, which they had because they were Portuguese citizens. So when all these returners arrived in Portugal after independence, among them were many Cape Verdeans. They were highly qualified because they had worked for the Portuguese colonial apparatus. ... The face of colonialism for many Angolans and Mozambicans was not Portuguese, but Cape Verdean. ${ }^{6}$

Most returners moved to Portugal because of the links they had forged during colonial times, when they had a direct connection to the colonizing state apparatus. Once in Portugal, they could count on pensions and social security schemes. They felt like, and most of them also officially were, Portuguese citizens, and all those who were not would become so after 1981. If they were Cape Verdean nationals, they would still fit the racial regime that was created during colonial times and then employed to construct social hierarchies in Portugal, as most Cape Verdeans are easily distinguishable from Angolans and Mozambicans by their lighter skin color.

As Reiter (2008) explains:

Under the indigenous law code that regulated life in most of the Portuguese world until 1961, some natives could become Portuguese citizens if they passed the "civilization-test," consisting of demonstrating their degree of assimilation to European values and manners. The Indigenous Code of 1954 regulated the stages that led from being "indigenous" to becoming "civilized," making the achievement of European manners and customs the benchmark for gaining access to Portuguese citizenship rights. Assimilated Portuguese citizens had to demonstrate that they had left their "native savagery" behind. Successful assimilation had to be proven through Portuguese language skills, clothing style, food habits, and other western civilized manners. (Reiter 2008: 403)

After 1974, Portuguese state elites thus took care of their own, and by doing so made sure uncivilized "others" could not slip in. However, the 
maintenance of bonds to individuals and groups with connections to the motherland is not an uncomplicated matter-especially not for Portugal, a country that had long claimed to be intimately close to their colonial subjects. Portuguese settlements in Brazil, Angola, Mozambique, GuineaBissau, Goa, Macao, South Africa, and Cape Verde reach back to the sixteenth century. Portuguese presence never effectively ended with independence, so that most of the former colonies still have a sizable Portuguese population. However, by the late 1990s, the economic boom that was caused by joining the EU and receiving millions of EU structural funds to improve infrastructure started to slow down, and unemployment started to rise. During that time, the first studies about remittances emerged. From the late 1990s onward, the amount of remittances to Portugal had declined steadily, down from accounting for 3 percent in 1990, to 2.5 percent of Portugal's GNP by the end of the decade. ${ }^{7}$

While colonial ties seemed to demand taking care of all those who had helped sustain the colonial apparatus by facilitating their integration into the Portuguese state, by the late 1990s it became clear that Portugal could not welcome all those communities that upheld their Portuguese nationality. Under these new economic circumstances, and equipped with hard evidence about the magnitude and importance of remittances for the Portuguese economy, Portuguese political elites shifted gear. They realized that it was no longer desirable to "bring home" all the former colonizers, or those who had passed the "civilization test" and could count on national solidarity based on their white skin or their white customs. While it still seemed important to keep the bonds that united these exile communities to the motherland, the sine qua non condition to ensure that remittances continued to flow "home," it seemed also important to ensure that these exiles stayed where they were, thus not further burdening the Portuguese labor market.

Political elites found the solution to these new challenges of the late 1990s in the Camóes Institute. Since 2000, new Camóes cultural centers were established in Paris and in Poitiers (France), Dakar (Senegal), Windhoek (Namibia), Dili (East Timor), Hamburg (Germany), Stockholm (Sweden), Vienna (Austria), and in the headquarters of the African Union in Addis Ababa (Ethiopia), and of the Economic Community of West African States in Abuja (Nigeria). Portuguese language centers were opened in Canchungo, Ongoré, Mansoa, Bafatá, Gabú, Buba, Catió, Bolama, Bubaque, and Quinhamel, all in Guinea-Bissau, to spread fluency in Portuguese as the official language in the country. Taken together, since 1998, the Portuguese state has opened nineteen language centers and is 
now present in twenty cities of different countries. According to Jorge Malheiros (2002), "Portugal's Ministry of Foreign Affairs has registered and attempts to maintain ties with nearly 4.3 million Portuguese and people with Portuguese ancestry living abroad." ${ }^{\prime}$ In 2007, the Camóes Institute, together with the Lisbon-based Instituto Superior de Ciências do Trabalhoe Empresa (ISCTE) determined that the Portuguese language contributed to 17 percent of the Portuguese GDP. ${ }^{9}$

Portuguese political elites have thus found a way to categorize their citizens into those who can live in Portugal and those who are more functional if and when they stay abroad but send their money home to their families. Not all passport holders are also welcome in the motherland-as the situation of all those who hold passports but are treated as foreigners demonstrates. Conversely, others have been received with open arms, and laws have been changed to accommodate them. The racial project that informs this sorting out of people and groups into desirable and lessdesirable ones is hard to overlook. Yet most Portuguese scholars do just that-be it because they cannot find funding for projects that would raise these issues, or because they are too caught up in a hegemonic common sense that has long accepted that nonwhites are not Portuguese and thus cannot count on the solidarity of the national community. By doing so, Portuguese academia gets implicated with the reproduction of a racialized common sense that legitimizes the maintenance of a racialized social order, dividing the Portuguese citizenry into first- and second-class citizens. Whereas the white (biologically or culturally defined) first-class citizens can count on citizenship rights as entitlements, second-class citizens have not been allowed to live the roles of citizens. The asset character of citizenship becomes evident, as all those benefiting from such a system have no reason to change it-and instead have every reason to hold the "others" out.

\section{CONCLUSION}

An ethnically defined nationalism has become the norm in Western Europe. Although its emergence can be explained by the late state formation of some EU member states, such as Germany (Hobsbawm 2003), other states, such as France or Portugal, have only recently shifted away from (in the case of Portugal) or restricted the reach of (in the case of France) the jus solis rules that have long been a cornerstone of their democracies. The contemporary 
strength of ethnic nationalism must thus be seen as the result of deliberate political action that is aimed at redrawing the rules and borders of belonging.

Ethnic nationalism, however, not only perpetuates the exclusion of nonwhites by defining them as not belonging to the national community; it also stands in the way of achieving truly universal citizenship and democracy with strong civic, political, and social components. A complication that adds to this problem is caused by the almost exclusive focus on citizenship rights - to the detriment of citizenship duties and responsibilities. Ethnically defined nationalism, coupled with a widely held belief that citizenship is a matter of rights without responsibilities and duties, has created a situation where ethnic white Europeans arrogantly insist on their "rights" as citizens, thus representing them as entitlements, while conveniently overlooking their responsibilities towards their fellow citizens. Instead, minority citizens get routinely blamed for all economic, social, and political problems that many European countries have experienced over the last decades.

The lack of a focus on civic solidarity and a civically defined membership is also at the core, I would contend, of the oftentimes awkward difficulties many European states and societies have when dealing with antidemocratic elements in their midst. Instead of focusing on antidemocratic agents as the prime culprits of terror and insecurity, blame is commonly shifted away from civic and political matters towards cultural and ethnic ones-thus religions, cultures, and ethnic groups are unduly blamed for violent acts and "tendencies," and stereotypes about "others" are further perpetuated.

To make matters worse, several European states do not provide census data on the ethnic backgrounds of their citizens, justifying such a policy with reference to the principle of universal citizenship. Minority citizens thus have no way of knowing their numbers, situations, and the degree to which they have a shared destiny. By most accounts, having access to these numbers could prove explosive and is thus avoided by status quo oriented political elites. Parallel to not providing census information on European minorities, several European states actively fund a plethora of studies that focus exclusively on immigrants, thus anchoring public attention and discourse firmly on issues of foreigners and their problems of attaining legality and achieving integration. Academia has become implicated in the dissemination of a framework that almost automatically transforms all nonwhites into foreigners and immigrants. There is a clear lack of studies on an increasingly diverse European citizenry and the difficulties of nonwhite citizens in finding acceptance, equal opportunities, and equal treatment by the state and other, white, citizens. They have become second-class citizens who are not allowed to experience the full extent of the social role that comes with the status of being a citizen. 
Broadly accepted racist practices support the discrimination of nonwhite European citizens and expose them to discriminatory practices. The unchallenged reproduction of discriminatory practices and policies provides evidence for the high degree to which such discrimination has been normalized. Extremely unjust racial regimes are thus being constructed, and their victims are robbed of the tools to face them effectively.

The influence of European racial regimes becomes even more evident when considering how some migrants, namely ethnic whites, have been able to successfully escape the status of victims. Post- 1974 white African immigrants to Portugal have successfully claimed the status of "returners" (retornados), which has allowed them to successfully settle in Portugal, even though some of them were born in Africa to families that had lived in Africa for several generations. In 1981 the Portuguese National Assembly effectively passed a law restricting Portuguese citizenship to those of Portuguese descent - thereby shifting citizenship criteria from jus solis to jus sanguinis in order to accommodate white "returners" and facilitate their integration. But what, if not ethnicity, makes one a "returner"?

Ethnic nationalism, coupled with inherent problems of majority rule, are thus at the core of many problems of contemporary European states and societies. Instead of blaming immigrants, EU member states ought to make democracy the EU's foundational element, and membership dependent on the willingness to actively support and defend democracy, which would imply a stronger focus on citizenship responsibilities. But instead of focusing on democracy and its requirements, political elites have successfully shifted the focus onto migrants and foreigners and made them the culprits of most of the social problems European societies face today. Such a focus allows those same elites to avoid being blamed for the problems that they are ultimately responsible for. Scholars, who in their studies focus excessively on immigrants and foreigners, further contribute to a hegemonic common sense that transforms nonwhites into foreigners and intruders. In doing so, they support political elites in their maneuvering and provide them with legitimacy.

If anything, social scientists should produce more studies on failing and unresponsive states, inefficient bureaucracies, and inadequate democratic institutions. They should also unveil more of the injustices and problems that a significant part of the European citizenry routinely faces. If they would do so, we might have a chance to improve current situations and work towards more just and inclusive democracies, which might also prove more economically efficient - at least if we believe the Nobel Prize-winning economist Amartya Sen (2000). 



\section{Brazil}

\section{Experts in Exclusion}

After the uprising of 17 June the secretary of the Writers' Union distributed pamphlets on Stalinallee, which stated that the people had forfeited the trust of the government and could only win it back by doubling their work effort. Wouldn't it be simpler if the government dissolved the people and elected another?

-BERTHOLD BRECHT, JUNE 1953

This Chapter focuses on yet another illustrative Case: Brazil. As I have done before, I present each case to highlight one particular aspect of the dialectics of citizenship. In this chapter, the main focus is "how exclusion works." I have chosen Brazil as an example to explain how exclusion works not because Brazil is peculiar in this respect. To the contrary, Brazil is typical. The ways in which exclusion is produced and reproduced there are repeated elsewhere in the same, or very similar, ways. Thus, Brazil is a "case" introduced to unveil and highlight the causal mechanisms that typically are put to work by those who seek to defend their own privileges by excluding, stigmatizing, and discriminating against others. My own familiarity with Brazil and Brazilian Portuguese allows me to take a closer look at and a deeper examination of how exclusion works. The Brazilian case allows us to explore the microdynamics of how the reproduction and defense of privilege produces exclusion. It also allows us to take a closer look at the interpersonal and intergroup level of this dynamic-without, however, claiming that the interpersonal level is the only one of relevance when analyzing the dialectics of inclusion and exclusion. The Brazilian case, to the 
contrary, is intended to add texture and complexity to the manifold ways in which inclusion and exclusion constitute each other.

Why Brazil? one could ask. Brazil fulfills the conditions of a typical case because of the richness and clarity of the causal mechanisms used in this process. Brazilians are indeed "experts in exclusion" and as such, they provide a very clear and textured image of how exclusion works at the interpersonal and intergroup level. Given that individual and group interactions become institutionalized and shape social structures, the way in which Brazilians exclude also allows us to see how Brazilian social structures have been constructed around this exclusion. To be sure, implicit in this exploratory analysis of Brazil is that we can learn something about how exclusion works in general.

Of central importance in the process of exclusion and discriminationthat is, of withholding full access to the rights citizenship promises-some factors stand out as particularly relevant-namely, racism, the importance of linguistic codes, and the strategic use of formalistic protocols for exclusion. The end result of these different ways to exclude, which are in reality not separable, is a phenomenon I have called "the formal versus the informal." Formality in language, in general habitus, and in the structuring of institutions conditions access to the spheres of power and money, as this chapter will show. By doing so, it excludes all those who are stuck in their own informality, mostly due to their lack of formal education, from full citizenship.

This finding also provides the caveat of this analysis. This way of reproducing privilege works best where parts of the population are rather less educated, or differently educated, than those that control the spheres of power and money. While diverse educational backgrounds are the most common ground upon which such a way to exclude works, the presence of different language codes, where one stands out as the "high" variety and others are thus declared "low" or "vulgar," provides another typical background for this type of exclusion. Brazil, thus, represents a typical case for how exclusion works in colonized societies.

\section{WHITENESS AS CAPITAL}

A recent poll on Bolsa Familia recipients, conducted by the Rio de Janeirobased Laboratory for Economic, Historical, Social and Statistical Analyses of Race Relations (LAESER), found that of the 10.2 million families (18 percent of all households) in this income transfer program aimed at Brazil's 
most destitute families, 66.4 percent were Afro-Brazilians (the chief of the household self-classified as either preto or pardo) and 26.8 percent selfdeclared "white." Nationwide, almost one-fourth of Afro-Brazilian families were enrolled in this program. Afro-Brazilians thus continue to occupy the lowest ranks of Brazilian social hierarchies.

In general, when comparing such highly consequential indicators as years of schooling, the latest data confirms a long-lasting trend: namely, that where in 1988, Afro-Brazilians (pretos and pardos) had completed on average 3.6 school years, whites had completed 5.2 years. Twenty years later (in 2008), both groups had improved, but the gap separating whites from blacks had grown; in 2008, Afro-Brazilians had completed on average 6.5 years of schooling, while whites had finished 8.3 years. The educational gap separating white from black Brazilians thus has actually grown from 1.6 years in 1988 to 1.8 years in 2008. Similarly, the proportion of AfroBrazilians in the "poverty" category has remained double that for whites.

The meaning of "being white," however, is anything but clear in a country like Brazil, where whiteness is not a biological reality, but is used as a symbolic indicator of civilizational potential. Jeffrey Lesser (1999) demonstrated that what it meant to be "white" shifted in Brazil between 1850 and 1950, but whiteness remained a relevant and consequential category that continued to allow for the self-identification with a group. To this day, it signifies superiority and well-deserved privilege. During the nineteenth century, Brazilian elites openly discussed and compared the different degrees of whiteness of such potential immigrants as Arabs, Japanese, and Southern Europeans, associating whiteness with aptitude-especially for their potential to whiten the highly mixed Brazilians. Inspired by the racial science and ideology of the time, the declared goal of Brazilian elites was to attract white ingredients that would further lighten the racial mixture that made up the Brazilian population, thus allowing it to become "civilized." During the late nineteenth and early twentieth centuries, whiteness thus was constructed as a form of capital, strongly associated with merit and progressive, developmental potential.

French sociologist Pierre Bourdieu's (1984) Theory of Distinction allows for conceptualizing whiteness as a symbolic capital that structures social hierarchies. According to Bourdieu, "The volume and composition of capital give specific form and value to the determinations which the other factors (age, sex, place of residence etc.) impose on practices. Sexual properties are as inseparable from class practices as the yellowness of a lemon is from its acidity: a class is defined in an essential respect by the place and value it gives to the sexes and to their socially constituted dispositions" (Bourdieu 
1984: 107). The same can be said of ethnic properties. Whiteness, conceived in this way, constitutes a capital in addition to the other capitals, namely, financial, social, and cultural. The relative presence or absence of these capitals determine the social place an individual occupies in a society, where much of the outcome is determined by the successful performance of that which is perceived as typical "white" behavior. This performance is particularly important in societies without a rigid color line, where belonging to one status group or another has to be constantly negotiated and upheld. It is in this sense that whiteness constitutes a "racial capital"—one that signals the presence of other capitals, even though they might not be present. Blackness, at the same time, signifies the absence of other capitals. Both whiteness and blackness thus overdetermine (Reiter 2009; Harris 1993).

As a result, the strategic use of whiteness as a symbolic capital in Brazil is tied to a broader strategy to defend historically inherited privileges associated with status - including the status of being a citizen invested with specific rights and privileges. Hence, one of the main mechanisms by which the effectiveness of citizenship is denied is racism. For many minorities, racism translates into second-class citizenship, as it undermines trust in public institutions and exposes some to the discriminatory practices of their fellow citizens. Whiteness tends to become normalized, thus made both the norm and normal in a process that produces a racialization of nonwhites, who in this process are transformed into "others." Successfully claiming to be white, in all those societies structured by European colonialism, functions as a symbolic capital that marks one's belonging to the group of the historically privileged - those who have rights and can give favors. It also fulfills important gate-keeping functions, because it eases the sorting out of those who "deserve" privileges from those who do not (Quijano 2008; Telles and Flores, forthcoming). The process through which this structuring of social hierarchies works separates people into different status groups, with all those who are able to successfully claim whiteness adding a very powerful and highly consequential symbolic capital to their account.

The result of upholding whiteness as a criterion for privilege and using it as a demarcation to separate first- from second-class citizens provides a formidable barrier to achieving general, substantive citizenship. It has the potential to place nonwhite formal citizens outside the realm of effective citizenship - at least in those societal spheres that are firmly controlled by those able to claim whiteness. Given Brazil's colonial past, the societal spheres where whiteness carries the highest value tend to be those where money and power are brokered. 


\section{PROTOCOLS}

In July 2008, I interviewed a group of black women organized as a local NGO in the Brazilian city of São Luis. Their organization is dedicated to assisting the poor inhabitants of this city of about one million in their quest to receive federal housing benefits and qualify for federally funded low-income housing loans. Concretely, they help those who qualify apply for state-backed mortgages, given to them by a state-controlled bank, the Caixa Economica Federal. The very existence of such an NGO points to the difficulties ordinary citizens often encounter when dealing with the public realm. During the interview, as they were telling me about their very frequent dealings with both bank managers and state officials, after about thirty minutes of engaged talk, I ended up asking directly about my main interest: how are you received and treated by these representatives of power and moneygiven that you are female, black, and poor? At that point, their statements became more vivid, and the main spokeswoman explained:

It takes us one entire year to fill out all the forms required by the Caixa Economica. If we go to the municipal secretary of city management and ask for a meeting with the secretary, the person at the entrance gives us a very hard time and schedules a meeting in two months. ... We feel discrimination every day. Our biggest challenge is to overcome that. The prejudice is very strong. The bureaucratic hurdles are very great and we always have to quebrar protocolos. ${ }^{1}$

This statement is typical and hints at two often-cited problems: first, the extremely complicated procedures and forms applicants have to fill out when they want to apply for a state program. In fact, formal application requirements can be so burdensome and require such sophisticated knowledge and formal writing skills that ordinary people are effectively barred from having access. Those who still want to apply have to recruit specialists in the form of lawyers - or, if they are lucky, local nonprofit organizations that assist them in the application process, as is the case here. Offering a low-income housing loan program, but then designing the required paperwork in such a way that most low-income people cannot fill out the forms, casts severe doubt on the seriousness and commitment of the federal bank that has developed these procedures and made them a requirement. Offering a federal housing program for the historically excluded, but then barring their access through complicated procedures and forms that fulfill gatekeeping functions that keep the truly needy out certainly creates a feeling of 
alienation among all those who qualify for this program but are unable to fill out the necessary forms.

The second important piece of empirical information coming out of the above statement is the experience of discrimination and racism related by the informant. Their skin color, gender, and other physical characteristics mark them in the eyes of biased interlocutors as poor and uneducated. In a bank, this biased assessment quickly translates into a perception of not being a valuable client, but rather a needy and bothersome petitioner-and thus, in the eyes of bank personnel, not worth their while. The same logic applies in a government environment, where black females are routinely perceived as poor and thus unimportant power brokers who possess nothing of value to offer. In other words, they are prejudged for being black and poor, as in the eyes of the observer, these two characteristics "naturally" go together. As this prejudgment potentially bars their access to the formally established channels of interaction with banks and political office holders, the interviewees resort to a strategy of "quebrar protocolos"-which translates into breaking protocols.

What are those protocols? In this concrete case, the interviewees would have to stand in line, fill out forms, make appointments, come back for more appointments, stand in line again, fill out more forms-in short, the access to the decision-making spheres would be so burdensome and lengthy, and the final success so uncertain, that many applicants would desist from pursuing their goals. Elisa Reis (1990), who analyzed 27,367 petition letters sent to the Brazilian minister of De-bureaucratization between 1980 and 1982, offers some further insight into this reality. Reis, for example, describes a widow who in her letter to the minister complains that she has to go repeatedly to the physician to get a certificate that states that she is still alive and thus eligible to receive her pension (Reis 1990: 165). Another letter analyzed by Reis states,

In six months, I went seven times to the office of the IRS ("Delegacia da Receita") to get information about my income declaration. In order to get a personal loan, I had to go to this same federal office 36 times in seven months. (Quoted in Reis 1990: 166, my translation)

Another example:

I have already gathered 425 documents in response to the demands of the federal government in order to prove that I have dealt correctly with all the fiscal requirements of my small firm. (Quoted in Reis 1990: 166, my translation) 
And finally:

I spent 12 hours waiting in line, under heavy rain, in order to get the money that I so desperately need, but to no avail. Why have workers to be treated so inhumanly? (Quoted in Reis 1990: 166, my translation)

Why indeed? All these examples express a very typical situation that can easily and readily be observed by anyone expecting any type of service in Brazil, public or private- even though the overall quality of services has improved since the 1980s. The writer of these lines can amply testify to waiting hours in line to resolve such simple issues as making a deposit into one's own bank account or withdrawing money from it, as well as to waiting for hours in the antechamber of some local civil "servant" before he or she finally grants "an audience." It appears that the Brazilian state, as well as some service-related businesses have wrapped themselves in a shell of formalities and procedural protocols that have the effect of keeping ordinary citizens out-or forcing them through an almost ritualistic procedure of self-humiliation when seeking to reach those institutions and people that supposedly work for them. This strategy of bureaucratic isolation works through several mechanisms. It makes use of complicated procedures to make access more difficult, especially for all those unable to maneuver their way through these hurdles because of their lack of formal training, or simply because they are unwilling or unable to tolerate the humiliation that often seems an integral part of the procedure (again: the author has himself pondered several times about how much humiliation and mistreatment he was willing to accept in order to receive something from a civil servant or someone else thinking of him- or herself as important).

This form of excessive state autonomy and office abuse has deep historical roots in Brazil. According to Florestan Fernandes (2006), during the early twentieth century, when the sons of plantation owners moved to the cities, they brought with them their aristocratic demeanor, which led to a "bureaucratization of patrimonial domination" (Fernandes 2006: 116, my translation). Raymundo Faoro ([1957] 2001), who has produced the most detailed explanation for this isolation of the state from people, argues that "The stand (or status group), serving as the administrative rank for the exercise of dominion, configures a minority government. Few rule, control and spread their patterns of conduct to the many. The leading group does not exercise power by delegation or inspired by the trust that the people, as a global entity, irradiate. It is a sovereignty that encysts itself, impenetrable and superior, a restricted stratum, ignorant of the dogma of majority 
rule." (Faoro 2001: 108, my translation) According to Faoro, the patrimony of the king was gradually shifted over to the state and administered by an increasingly bureaucratic status group. Thus, explains Faoro, holding a state position, instead of representing a calling to serve the people, "transforms the holder into an authoritative figure. It gives him the mark of nobility" (Faoro 2001: 197, my translation). In sum, the way a public official envisions his or her governmental position is not one of "representing" or even "serving the public." Government officials not only perceive themselves often as disconnected from "the people," they feel superior to them, distinguished by the position they hold and by the honorific treatment it bestows on them.

This way of relating to the public is, however, not restricted to the state. As mentioned above, similar behavioral patterns can be found in banks or other situations where ordinary people need to interact with those who are higher up in the societal hierarchy. In a deeply divided and highly racialized society, such as Brazil's, it becomes clear that the abuse of power by state officials, the rich, or all those in situations of power is not random, but rather part of a general pattern of social interaction between different status groups. It is the way in which the members of formal or official society, who see themselves as the legitimate inheritors of the country as it was handed down from Portugal, relate to all those of the informal sector of society, which in a country like Brazil constitute some 40 percent of the population.

\section{THE LANGUAGE OF EXCLUSION}

The use of protocols to defend status privilege is operationalized in daily encounters between the members of formal and informal Brazil and serves an important gate-keeping function, where the performance and display of formality in language, conduct, and general habitus play important roles (Bourdieu 1987, 2003). One of the central mechanisms for enacting protocols is through the strategic use of language, or more precisely: linguistic codes. In the following, I will thus take a closer look at Brazilian Portuguese language codes and how they are used to uphold privilege and first-class citizenship by demarcating the speaker from all those thus transformed into second-class citizens. Brazil, again, is an ideal case for this inquiry because of its highly divided society, especially along educational lines. In a country where access to formal education is highly restricted, the use of formal 
education to defend privilege becomes a very central tool. To be sure, in 2009, the average years of schooling had reached 7.5 years - up from under 5 years only recently. However, according to the Brazilian Institute of Geography and Statistics (IBGE), in 2009, some 25 percent of adults (older than fifteen) self-declaring either preto or pardo were functionally illiterate, ${ }^{3}$ as were 15 percent of whites. At the same time, in 2009 only 10 percent of Brazilians between twenty-five and thirty-four years had a university degree ( 8 percent in the age bracket fifty-five to sixty-four; IBGE), thus allowing those with diplomas to reap very tangible advantages from their elevated educational levels. This situation is made worse by the low quality of Brazilian public basic education, which, while it seeks to educate the great majority of Brazilians ( 85 percent), also stigmatizes them and often bars their access to institutions of higher education (Reiter 2010, 2009).

Formality in language in such a context becomes a way to constitute privilege and demarcate the outer boundaries of this privilege through the use of formal language code. Brazilian Portuguese language and habitus thus are full of gate-keeping utterances and conducts. This starts with the naming of average people as gentinha, povão, Zé Ninguem, Pé de Chinelo, and others. All these terms refer to what would be called "people" in English. On the other hand, those classified in such a way smartly refer to those dominating them as barão-that is, barons - at least in the regional context that is informing this study, namely the Northeast of Brazil. The use of the term "baron" clearly indicates the strategies used by the historically included to defend their privilege—namely, by giving themselves an aristocratic air in both demeanor and language. Before going into some more concrete examples that show how this works in everyday encounters, I want to lay out some of the theoretical underpinnings upon which the empirical analysis can be conducted.

Language not only represents difference, privilege, and distinction-it also creates and sustains them. John B. Thompson, who wrote the editor's introduction to Pierre Bourdieu's Language and Symbolic Power (2003), explains, "The more linguistic capital that speakers possess, the more they are able to exploit the system of differences to their advantage and thereby secure a profit of distinction. For the forms of expression which are the most unequally distributed, both in the sense that conditions for the acquisition of the capacity to produce them are restricted and in the sense that the expressions themselves are relatively rare on the markets where they appear" (Thompson 2003: 19).

Pierre Bourdieu indeed offers an analytical framework that allows us to analyze language in its relation to power. Bourdieu argues that, in general, 
"the social uses of language owe their specifically social value to the fact that they tend to be organized in systems of differences . . . which reproduce, in the symbolic order of differential deviations, the system of social difference" (Bourdieu 2003: 54). To Bourdieu, language is but one manifestation, as well as a tool to negotiate difference in daily interactions. He explains, "Linguistic exchange ... is also an economic exchange which is established within a particular symbolic relation of power between a producer, endowed with a certain linguistic capital, and a consumer (or a market), and which is capable of producing a certain material or symbolic profit. In other words, utterances are not only (save in exceptional circumstances) signs to be understood and deciphered; they are also signs of wealth, intended to be evaluated and appreciated, and signs of authority, intended to be believed and obeyed" (Bourdieu 2003: 66). Next to financial capital, Bourdieu demonstrates that other capitals are equally functional in structuring social space. Next to social and cultural capital, Bourdieu argues for considering "linguistic capital, producing a profit of distinction" (Bourdieu 2003: 55).

For Bourdieu, then, language reflects and enacts social hierarchy, and for him, "the whole social structure is present in each interaction" (Bourdieu 2003: 67). Once this basic insight is understood, it can be applied to the analysis of more specific constellations-for example, to what is often called the "high," or official, variety of a language. Bourdieu explains, for example, that "All linguistic practices are measured against the legitimate practices, i.e. the practices of those who are dominant" (Bourdieu 2003: 53). He also explains the effects that the use of different language codes has on the speaker: "Speakers lacking the legitimate competence are de facto excluded from the social domains in which this competence is required, or are condemned to silence" (Bourdieu 2003: 55). When examining the genealogy of this high language, Bourdieu finds that "the official language is bound up with the state, both in its genesis and in its social uses. It is in the process of state formation that the conditions are created for the constitution of a unified linguistic market, dominated by the official language" (Bourdieu 2003: 45).

From there, Bourdieu is also able to shed light on the opposite end of the language continuum. When writing about "popular language," Bourdieu finds that "reduced to the status of quaint or vulgar jargons, in either case unsuitable for formal occasions, popular uses of the official language undergo a systematic devaluation" (Bourdieu 2003: 54). Seen through this prism, such power-constituting speech acts as condescendence reveal their social function: "The strategy of condescension consists in deriving profit from the objective relation of power between the languages that confront 
one another in practice ... in the very act of symbolically negating that relation, namely, the hierarchy of the languages and of those who speak them" (Bourdieu 2003: 68). Just like any other market, the laws of scarcity also apply to the linguistic market: "The more formal the market is, the more practically congruent with the norms of the legitimate language, the more it is dominated by the dominant, i.e. by the holders of the legitimate competence, authorized to speak with authority" (Bourdieu 2003: 69).

The effects of linguistic capital are manifold, especially in the field of domination: "The reality of linguistic legitimacy consists precisely in the fact that dominated individuals are always under the potential jurisdiction of formal law, even when they spend all their lives, like the thief described by Weber, beyond its reach, so that when placed in a formal situation they are doomed to silence or to the broken discourse which linguistic investigation often reports" (Bourdieu 2003: 71f). Dominant language does more than control those unable to speak or write it. It silences. "The constraints exercised by the market via the anticipation of possible profit naturally take the form of an anticipated censorship, of a self-censorship which determines not only the manner of saying, that is, the choice of language-'code switching' in situations of bilingualism-or 'level' of language, but also what it will be possible or not to say" (Bourdieu 2003: 77). This happens, according to Bourdieu, because "the sense of the value of one's own linguistic products is a fundamental dimension of the sense of knowing the place which one occupies in the social space. One's original relation with different markets and the experience of the sanctions applied to one's own body, are doubtless some of the mediations which help to constitute that sense of one's own social worth which governs the practical relation to different markets (shyness, confidence, etc.) and, more generally, one's whole physical posture in the social world" (Bourdieu 2003: 82).

According to the Italian anthropological linguist Maurizzio Gnerre (1991), who wrote about this phenomenon in Brazil, "The official language is a communicative system that is accessible only to a reduced part of the members of a community; it is a system associated with a cultural patrimony presented as a body of values, fixed by written language" (Gnerre 1991: 6, my translation). This is certainly the case in Brazil, where over 20 percent of the population is classified as functionally illiterate, which means they have no access, let alone dominion, of such elaborate, formal language codes. Gnerre finds that "Citizens, even if declared equal before the law, are in reality discriminated against even on the basis of the very code in which the law was written. The majority of the citizens does not have access to this code, or, in some cases, has limited access" (Gnerre 1991: 10). 
The same author also explains that "The separation between the 'cultured' or 'official' variety and the others is profound due to different reasons: the cultured variety is associated with the written variety ... and it is associated to the grammatical tradition; it is inventoried in the dictionaries and it is the bearer of legitimate cultural tradition and national identity" (Gnerre 1991: 11). Gnerre leaves no doubt about the function of elaborate language code usage- a function that can be traced back to the sixteenth century and that still today serves the purpose of constituting power.

As Benedict Anderson (2006) has described, and Martin Luther demonstrated much earlier in practice, any communication — written or oral—done in an exclusive language code such as Latin or grammatically correct European Portuguese serves the purpose of restricting the circle of participants to a minimum; and it is this restricted circle of the educated, or initiated, few who tend to use their privileged access not only to dominate and control the majority, but also to renew their own source of legitimacy with reference to access to privileged knowledge. The circular logic becomes evident: the powerful define an exclusive language and codify it; then they use it to wield their power; and finally, they bolster their power through linguistic exclusivity. As Gnerre highlights, "Language constitutes the most powerful barbed wire to block access to power" (Gnerre 1991: 22).

In a Brazilian context, the language of the initiated, the high, sophisticated written Portuguese is the Portuguese that was codified in Coimbra and has its Portuguese purity upheld by the Academia Brasileira de Letras, the Brazilian Academy of Literature. It is a Portuguese that excludes all those who are functionally illiterate or otherwise stuck in their own informality. This become particularly relevant in context where the formally educated control and regulate access to spheres of power, such as state agencies and banks. In these environments, formal language and sophisticated procedural protocols serve as very effective means to keep all informal elements out. Informality, in this Brazilian context, refers to all those not able to dominate and manipulate elaborate codes, thus marking them as potentially uneducated and poor.

In 2009, some 21.7 percent of Brazilians fifteen years and older were classified as functionally illiterate (defined by UNESCO as the percentage of the population aged fifteen or over with less than four years of study). ${ }^{4}$ A 2007 World Bank study found that Brazil's first-grade repetition rate is 28 percent, among the highest in the world. It also stated that "According to the international PISA tests, approximately half of Brazilian 15-year-olds have difficulty reading or cannot read at all; and about three-fourths cannot manage basic mathematical operations." ${ }^{5}$ According to Ulyssea and Szerman 
(2006) some 35 percent of Brazilians are active in the informal sector, which provides a low estimate of all those effectively excluded from the spheres of society reserved for the formal or official society, thus suggesting a strong overlap of economic informality, illiteracy, poverty, and blackness. Indeed, the divisions of Brazilian society run deep and can be traced back to colonial times. From the beginning of the colony, privileged Brazilians were part of what Franklin Knight (1990) has called the "official society" - a term he employs to describe that part of plantation societies that had access to the formal and literate world. The majority of a plantation society, according to Knight, was informal. They emerged unplanned, as an unintended side effect of slavery and indentured labor. The Portuguese crown, as well as the independent Brazilian government, for a long time had no real plan for these groups. They were simply seen as a problem and finally became "the social problem" under Getúlio Vargas, under whose presidency the first social programs were enacted targeting these groups who were poor, increasingly urban, functionally or altogether illiterate, and nonwhite. Those social groups that were perceived as problematic under Vargas have indeed never been able to successfully challenge, let alone reverse, the social hierarchies that projected them to the bottom. Even after democratization and broad political inclusion, in 1988, the system of values and norms upon which social hierarchies is constructed survived, having led some to refer to Brazil as the "unrevolutionary society" (Mander 1969). Indeed, with few exceptions, many poor, black, and indigenous Brazilians are still excluded from being considered equal members, and their access to full citizenship is barred. The mechanisms for keeping them out, however, have changed over time.

Brazil has a long history of applying criteria to separate the formal from the informal society, and then using this separation to justify privilege and citizenship for one group, and exclusion and second-class citizenship for the other. As James Holston (2008) has shown recently, the Brazilian electoral law of 1881 introduced direct, voluntary elections, but as it did so, it also established both literacy and proof-of-income requirements, with the result that Brazil witnessed a decline of voters to 2 percent of adults, or 1 percent of the total population (Holston 2008: 102). Holston also shows that in Brazil, illiteracy restrictions were maintained until 1985, and even the new 1988 constitution, with 50 percent illiterate in 1950 and 25 percent in 1980, has led him to conclude that "Regardless of political regime - under monarchy, democracy, and dictatorship — the few ruled" (Holston 2008: 103).

Even though this scenario changed completely in 1988, when the franchise was extended to include illiterates and the voting age was lowered to sixteen, in contemporary Brazil one of the clearest legacies of colonial 
domination is the existence of different Portuguese language codes-apart from the different local dialects. One is the official language, which follows a Portuguese grammar and demands a sophisticated use of pronouns and articles. The other one is the Brazilian-spoken Portuguese broadly used by the "popular classes." In this variety, there are no pronouns and attached articles, no dei-lhe or even dar-lhe-ei. Instead, there is dei para ele/ela and vou dar para ele/ela. Formal Brazilian Portuguese grows out of Portuguese from Portugal and thus carries with it grammatical forms that are not used in Brazilian colloquial language. Brazilian elites have thus long used elaborate languages codes to set themselves apart, especially in written Portuguese. This was noted as early as in the 1940s, for example, by Claude Levi-Strauss, when he was in São Paulo helping to establish the University of São Paulo. Here is a quote about his students: "Learning was something for which they had neither the taste nor the method; yet they felt bound to include in their essays, no matter what their nominal subject might be, a survey of human evolution from the anthropoid apes to the present day. Quotations from Plato, Aristotle and Auguste Comte would be followed by a peroration paraphrased from some egregious hack-the obscurer the better, for their purpose" (quoted in Mander 1969: 289). Their purpose was, of course, to achieve distinction and to set themselves apart from ordinary Brazilians.

\section{THE CODIFIED LANGUAGE OF THE LAW}

A very consequential domain where this distinction between the formal and the informal has a structuring force is the law. As Gnerre (1991) explains, "To compose a document of any judicial value it is not only necessary to know a language and be able to write intelligible phrases, but one must also be familiar with a whole complex and archaic phraseology" (Gnerre 1991: 22). This is indeed the language used in judicial documents, and the testimony from the above interviewees hints at this difficulty. If it takes one year to fill out an application for a social housing program, it is safe to say that this is not an unintended side effect, but rather a functional ingredient of the application process. The same logic applies to Brazil's legal codes in general: written by erudite lawyers and humanistic scholars, they are not written for the informal sector of Brazil's society. Instead, they serve the function of establishing prestige by placing them at the cultural height of the colonizing nation and other nations commonly perceived as civilized 
and cultured. After all, as Gnerre explains, "The central function of all special languages is social: they have a real communicative value, but they exclude the people who belong to linguistic out-groups and, at the same time, they fulfill the function of reaffirming the identity of the members of the in-group" (Gnerre 1991: 23).

To illustrate this phenomenon, I am reproducing a passage from an article I wrote together with a Brazilian federal judge, in 2007, about precisely the exclusion that the use of sophisticated language codes creates:

To penetrate the spheres of power, Brazilian citizens have to imitate the habitus of the powerful. Recently, Brazil initiated a movement, led by the association of Brazilian Magistrates (АМВ), aimed at convincing its members to change its language. Our preliminary observations, as participants in this effort, lead us to a pessimistic diagnosis of this initiative, given that the discussions in this respect already started without focus, which demonstrates the degree of alienation of these attempts, endogenous to the baccalaurean problematic, as it confounds language with stylized profile and forgets the buffonian warning that "le style est l'homme même," while at the same time going against the terminological specialization-from which we get the socalled "technolets" - that every scientific-technical knowledge must have. In reality, this topic has a profoundness that is not perceivable with such superficiality: throughout its historical development, the baccalaurean juridical language has remained encapsulated the same way as the knowledge that it transmits, neglecting that "la liberdad del lenguaje es libertad histórica, libertad del hombre como ser histórico." Without facing the social reality to which theoretically it should dedicate itself, this instrumental phraseology, even if in fact less invaded by literary affections of doubtable gusto, has remained in a somewhat social schizophrenic state in a time when belletristic has lost its influence in the formation of contemporary baccalaureates. (Castro Jr. and Reiter 2007: 96, my translation) ${ }^{6}$

It is hard to overstate the comic effect that this appeal for the use of a simple language made by a Brazilian federal judge produces. However, it illustrates just how difficult it is for those who are members of such an elite group as Brazilian federal judges to make a genuine connection to ordinary citizens. Apparently against their overt intention, their language continues to exclude by virtue of its elevated code. Another example of the exclusionary effect of language is this excerpt from the Brazilian Diario Oficial, that is, the official newspaper of the federal government to inform its citizens of what it has decided. 
Ministry of Justice

National Council for the Rights of Children and Adolescents

Act of the seventy-seventh ordinary assembly, held on February 14 of 2001

At nine hours and forty minutes of the fourteenth of February of two thousand and one, the seventy-seventh ordinary assembly of the national council for the rights of children and adolescents (CONADA), presided over by its president, Cláudio Augusto Vieira da Silva, (Foundation Fe e Alegria do Brasil). Present are ... We take notice of the justified absence of ... We have called on the presence of nonprofit councilors . . . as well as civil society deputy councilors ...

The president opened the session, offering his welcome to all and thanking them for their participation in this first assembly of the new millennium. He then submitted the minutes to the plenary. They were approved, with exception of item eight of the second day, shifting it to the fourth item of the first day. For the item "General topics," the scheduling of executive assemblies were solicited; discussion of the Direct Action of Unconstitutionality of articles two hundred and fifty-four and two hundred and fifty-five of the Law for the Child and the Adolescent (Estatuto da Criança e do Adolescente), proposed by the Brazilian Workers Party - РТВ - with the participation of CONANDA in the Committee of Supervision of the Social Policies for Public Safety. The other items remained unaltered. Continuing, the President proposed changes in the composition of the existing Thematic Commissions and Working Groups, justifying that such a change would not hurt the Internal Regimentation of the Council. He informed that the commissions would bring the thematic angles (éixos temáticos) together, as they would function as follows: 1) Commission of Articulation-would have as a thematic angle the State, Municipal, and Capital Councils and the Title Councils; 2) Commission for Budgeting and Finance-would have as a thematic angle the socio-educational measures; 3) Commission for Public Policies_-would have the fourth National Conference as a thematic angle; 4) Commission of Communication - the actions of this Commission would be developed in partnership with ANDI and be restricted to the necessary proceedings in order to develop a communication policy together with ANDI: The proposal was debated and approved by all. Next, the assembly moved to the composition of members, which was constituted as follows: . . The Technical Commissions met during the period of the morning and beginning of the afternoon in order to deal with specific issues of their area of action, to update the pending items of the previous assemblies and to elaborate an action plan and the goals for the exercise of two and one.

(excerpt from Diario Oficial da União, no. 67-E, 5a feira, April 5, 2001, page 2, sect. 1, my translation) ${ }^{7}$ 
What is it that they actually did and decided? It is indeed difficult to tell. Where in the first example, it was the use of elaborate language code that excludes, the second example constitutes a typical example of the exaggerated formalism and "protocolism" that characterizes Brazilian public politics-and thus provides a typical example of how formalism and protocolism exclude all those not prepared and trained in the skills of deciphering, let alone actively engaging in, elaborate and overly formalistic language games. Even if this type of exclusion is far from unique to Brazil, in the case of Brazil, the end results of both types of exclusion are that ordinary, informal citizens are routinely excluded from accessing the public sphere. The Brazilian public sphere-that is, the space where citizens and the government can connect and interact, where citizen voices and concerns can crystallize and solidify and ideally influence the government, holding it accountable and responsive-this public sphere is as divided as the rest of Brazil, as the inequalities that characterize and indeed structure broader Brazilian society spill over into the public sphere, dividing it into a plethora of different public spheres. Whereas those public spheres operating at the bottom of social hierarchies tend to be open and inclusive, even if homogeneous, those connected to the spheres of power and money tend to be dominated by individuals who are able to use their symbolic capitals strategically and in their own favor. The language and conduct of these public spheres is anything but public; it is official and erudite, formalistic and full of protocols. As such, it fulfills a gate-keeping function, excluding all those unable to participate in this erudite language game while at the same constituting privilege for all those who can.

The elite domination of some public spheres and the political realm per se finds reflection in the astonishing support that average Brazilians have given to those public representatives who stand up, or even just for, the informal sector of Brazilian society-that sector that cannot read the Diario Oficial or the complicated acts and decrees produced by Brazilian lawyers and judges. The election of Lula da Silva must certainly be understood in this light—as the election of someone "like us" — with only four years of formal education, who started to work at age twelve as a shoe shiner. The more recent election of Tiririca to serve as federal deputy provides yet another example of the same phenomenon. In the 2010 national elections, Tiririca received 1.3 million votes-more than any other candidate. Tiririca briefly faced a challenge for being considered illiterate, but ultimately passed this hurdle. In his campaign, he stated, for example:

Vote for Tiririca, it can't get any worse than it already is! (Vote no Tiririca, pior do que tá não fica!) 
Hi Folks, I am here to ask for your vote, because I want to be a federal representative, so I can help the most "needy," including my family. So my number is 2222. If you won't vote for me, I will dieeeee! (Oi gente, estou aqui para pedir seu voto porque eu quero ser deputado federal, para ajudar os mais necessitado, inclusive a minha família. Portanto meu número é 2222 . Se vocês não votarem, eu vou morreeer!)

Hi, I am Tiririca, from TV. I am a candidate for federal representative. What does a federal representative do? Actually, I don't know, but if you vote for me, I will tell you. (Oi, eu sou o Tiririca da televisão. Sou candidato a deputado federal. $\mathrm{O}$ que é que faz um deputado federal? $\mathrm{Na}$ realidade eu não sei, mas vote em mim, que te conto.)

Clearly, the greatest appeal of Tiririca was his informality, expressed in his very rudimentary Portuguese, full of semantic and grammatical "errors." This is yet another "man of the people" who does not represent traditional economic and educational elites and is himself not part of the traditional political elites - and is thus able to cater to all those who seek a more genuine representation. If self-rule and direct rule are impossible, then having a closer, more direct representation seems the second-best option for many who feel misrepresented, cheated, or not represented at all by political elites. ${ }^{8}$ Seen under this light, the election of Tiririca in 2010, and also the election of Lula to the presidency in 2002 and 2009, are calls for a more direct and immediate participation in politics, uttered by people who feel and know that they are excluded from it. If they cannot participate themselves directly, the next best thing is to elect a representative who is "one of us."

\section{CONCLUSION: THE FORMAL AGAINST THE INFORMAL}

"Domination is the requisite for exploitation," writes Anibal Quijano (2008: 220). Indeed, as the Brazilian case demonstrates, domination is an intricate, multidimensional, strategic game that makes use of different capitalsmaterial, symbolic, and linguistic - in order to uphold and actively defend privilege and regulate access to the spheres where power, money, and influence are brokered. People who do not look or talk "right" - that is, people unable to reproduce elaborate language codes, as well as women and nonwhites-are kept outside. Exclusion and a transformation of citizenship into a set of entitlements-accessible only to those with money, power, or access to other sorts of symbolic capitals—have alienated the common 
people from democracy in Brazil and elsewhere. The Brazilian case allows for an unveiling of some of the specific mechanisms at work that produce this alienation. Exclusion, the use of complicated and neocolonial protocols, the use of elevated language codes, a legal tradition that is based on colonial traditions that do not reflect the lifeworlds of ordinary people, and finally a transformation of democracy and citizenship from a regime where rulers and ruled strongly overlapped into a system where citizenship is a mere legal right - all these factors reinforce each other and alienate ordinary citizens from politics, the public sphere, the state, and government. The fault lines of these divisions have developed out of colonial scripts, where former colonizers have first become official citizens and later constituted the formal society, whereas the formerly colonized have remained informal and as such remain excluded from the official world (Mignolo 2008). And just as Alexis de Tocqueville (2003) argued in the early nineteenth century, democracy relies on the kind of social glue that associational life provides. If significant segments of a democratic citizenry feel alienated from politics, this glue is drying up and society falls apart into at least two disconnected groups: the included and the excluded, where the included have a tendency to perceive their own privileges as commodified entitlements, whereas the excluded have lost their stake in the polity. 



\section{Colombia}

\section{When Law and Reality Clash}

These are difficulties the man from the country has not expected; the Law, he thinks, should surely be accessible at all times and to everyone, but as he now takes a closer look at the doorkeeper in his fur coat, with his big sharp nose and long, thin, black Tartar beard, he decides that it is better to wait until he gets permission to enter. The doorkeeper gives him a stool and lets him sit down at one side of the door. There he sits for days and years.

-FRANZ KAFKA, BEFORE THE LAW, 1915

In i99i, the Colombian state declared itself a multiethnic and pluricultural nation. The new constitution also included Article 55, an affirmative action law for ethnic minorities. Law 70 of 1993, known as the Law of the Black Communities, soon followed, giving Afro-Colombian communities in the Pacific coastal areas the right to collectively own and control their ancestral lands. ${ }^{1}$

The new national legislation made it easier to enhance the relationship between Afro-Colombian organizations and the state. For most AfroColombian leaders, their historical claims for recognition as a marginalized minority group were officially validated when the state gave them the right to collectively negotiate their demands. The official recognition of their ethnic identity as a distinct minority group gave the Afro-Colombian advocates an unparalleled opportunity to approach state and international organizations. In 2000, after four years of debate, Law 649 was passed, providing that Afro-Colombians have the right to elect two congressmen as an ethnic group. Moreover, Colombia signed the International Labor Organization 
(ILO) Convention on Indigenous and Tribal Communities, ${ }^{2}$ as well as the International Convention on the Elimination of All Forms of Racial Discrimination of the United Nations. ${ }^{3}$

The legal recognition of Afro-Colombians and their rights as an ethnic group is the outcome of grass-roots organizing at the local, national, and international levels. Indeed, Afro-Colombians and their supporters have created such organizations as the Afro-Colombian National Conference, the National Association of Afro-Colombians Displaced by Violence (AFrodes), the National Association of Afro-Colombian Mayors (AMUNAFro), the Washington, D.C.-based Afro-Latino Development Alliance, the Black Community Process (PCN), and the AFrOAMERICA XXI-Colombia to advance their collective interests.

However, despite all these efforts and the legal successes that AfroColombian organizing has achieved through the years, most analysts find that the political and economic situation of Afro-Colombians, as well as their overall well-being and safety, has not improved significantly, even though overall violence in the country has ebbed (Urrea and Viafara 2006). According to the 2005 census, the infant mortality rate among Afro-descendants remains nearly twice as high as that of the rest of the population (48.1 compared to 26.9 per 1,000 live births). In Chocó, home to 44.1 percent of the total Afro-Colombian population, infant mortality rates have reached 77.5 per $1,000 .{ }^{4}$ Hence, the infant mortality rate in Chocó is comparable to that of the Republic of Congo, Ethiopia, and Mauritania (Observatory on Racial Discrimination 2008). How can this be explained? In other words: why has the livelihood of Afro-Colombians not improved despite the ratification and enactment of a whole series of progressive and protective laws? Concretely, the research question driving this project is this: In 1991, AfroColombians were recognized as a minority group and given collective rights. However, according to most analysts, these new rights have not translated into improved living conditions. Why?

To address this question, this chapter focuses on three causal factors that together provide a plausible answer to the question. I argue that, first, changed legal frameworks do not automatically change social realities; they only provide possibilities for change. Factual social change depends on the social power to bring it about, where different social groups assert different influences to bring about change, where change is mediated by the state and the state's own power. To put this into a schematic framework: pro-change forces face anti-change forces, where both seek to influence the state and are in turn influenced by it, taking advantage of the political opportunity structures that the state provides them (Tarrow 1994). Effective change thus 
depends on the relative power positions of pro-change forces, anti-change forces, and the relative autonomy (or lack thereof) of the state. Weak states that lack autonomy will be unable to change social realities, as they lack the resources to actually produce the kind of reality that the law depicts. Furthermore, weak states are weak because they lack legitimacy and thus cannot count on the compliance of their citizens, thus making it costly to enforce the rule of law and order (Bendix 1969; Mockus 2009).

Secondly, this general tendency is sharpened when the law does not grow out of social reality, but represents an unachieved ideal, expressing what ought to be, rather than what actually is. Such conditions of "legal idealism" (Moreno 1969) are worsened in extremely divided societies where lawmakers are not familiar with, and ultimately not interested in, the realities of the majority, let alone the reality of excluded and marginalized groups. This problem is made more acute due to the fact that citizenship in contemporary democracies inherited not just codification from Rome; according to John Pocock (1995), it was also during the Roman Empire that citizenship was forever transformed into a legal principle, thus losing its original Greek political content. Under such circumstances, existing legal frameworks can easily serve as tokens for substantial change, given that one of the central, and most consequential, places of exclusion in highly divided societies is the exclusion from the judiciary. As James Holston and Teresa Caldeira (1998) have demonstrated for Brazil, the poor and excluded simply do not have access to the court system, while inclusion is constituted and defined by just this access. These authors write that "The civil component of citizenship remains impaired as citizens suffer systematic violations of their rights. In such uncivil democracies, violence, injustice, and impunity are the norms" (in Agüero and Stark 1998: 263).

In Colombia, as elsewhere in the region, access to the courts has remained a privilege of the few. Once new laws are created, political elites can then retreat without being accused of not acting on behalf of the poor and excluded. The law, under such circumstances, has become a toothless scapegoat, replacing political action for change. ${ }^{5}$

Finally, overcoming persistent social forces aimed at reproducing the privilege of some by perpetuating the exclusion of others takes more than altering a law, or even a constitution. Racism, especially in societies that are officially colorblind and raceless, is a practice that easily escapes rigid legal frameworks, as it operates in gray zones of legality, structuring people's lives and the outlook one group has towards another (Wade 2005). None of these practices and the values associated with them can be eliminated by legal decree alone. 
In this chapter, then, I discuss these three themes one after the other by applying them to the case of Colombia and the specific situation of the Colombian Pacific Coast, home of a predominantly Afro-Colombian population. Colombia, and its Pacific rim in particular, thus present a demonstrative case that allows one to discern and describe the causal mechanisms at work with exceptional clarity. As such, Colombia represents a typical scenario, and understanding Colombia promises to shed light on other cases that present similar conditions for the independent variables at work here-namely, weak states, postcolonial legal frameworks, and ingrained racist practices in everyday interactions. To properly situate these approaches, I will begin with a short theory discussion of the works of Jürgen Habermas and Nancy Fraser.

\section{STUCK BETWEEN FACTS AND NORMS}

Jürgen Habermas's most significant contribution to contemporary democratic theory is his elaboration of a utopian model of democratic legitimacy, based on deliberate public consent and his grounding of morals and legal frameworks in democratic, rational communication. Distinguishing between lifeworld and system, Habermas finds that capitalism and the state exert control over citizens. Civil society, on the other hand, offers the possibility for free and uncoerced communication-thus making it the place par excellence for the renewal of democratic legitimacy. Writing in the Enlightenment tradition, Habermas takes on Max Weber's pessimistic critique of modernity and points to the positive and universalistic dimension of reasonable argumentation as a way out of Weber's inevitable "iron cage." In his vision, any mutually binding rule must be based on the agreement of all the potentially affected. Habermas does not argue that civil society or the public sphere have ever come close to this ideal. Instead, his Theory of Communicative Action explains what a democratic civil society and a democratic public sphere should look like, and what they can accomplish.

With regard to legal frameworks, Habermas (1998) argues that "the de facto validity of legal norms is determined by the degree to which such norms are acted on or implemented, and thus by the extent to which one can actually expect the addressees to accept them" (Habermas 1998: 30). In his 1998 book Between Facts and Norms, Habermas thus extends his work on democratic communication to the genesis of laws. Without engaging in some of the controversial discussions about the difference between 
legal language and common language (Abad I Ninet and Monserrat Molas 2009), Habermas's work still provides a useful framework for not only analyzing the difference, or gap, between legal norms and everyday facts; it also points out how to potentially bridge this gap. Concretely, Habermas offers a vision of how laws ought to emerge in democratic societies, namely, as institutionalized norms that have been created by democratic discourse. This discourse must be inclusive and follow democratic principles_ and as such, as argued above, it can best happen in diverse public spheres or in different associations that then together provide foci of democratic rationality, able to spread and disseminate democratic norms and values. Democratic laws, to put it bluntly, must emerge from below and should not be imposed on the people from above by elites.

Another helpful theorist able to advance this discussion is Nancy Fraser. Fraser (1998) has shown that contemporary injustices are rooted in a lack of recognition and a lack of economic distribution, where both mechanisms reinforce each other, but have distinguishable causes and results. Although economic inequality results in the stigmatization of the poor, Fraser argues that this stigmatization is not the cause of their poverty. Lack of recognition, on the contrary, expressed as cultural domination and racialized and gendered oppression, is a cause of injustice that persists even when economic equality is achieved. The recognition of the different causes of inequality brings Fraser to distinguish between different strategies to overcome them, as one strategy cannot address the different causes of oppression.

Fraser points at capitalism as the cause of economic inequality and socialization into fixed models of gendered and racialized identities as the root of cultural oppression. She finds that changing the causes behind these inequalities requires the radical deconstruction of "traditional" identities. The utopia of a radical deconstruction of traditional identities with fixed roles that ultimately deny change and learning brings Fraser close to the Habermasean project of the reasonable and democratic discussion about norms and rules involving all those potentially affected by a law. Such a nonauthoritarian defining of rules has been wrongly accused of being universalistic (e.g., by Fraser herself and Iris Marion Young [1990]). To the contrary, as a careful reading of the Theory of Communicative Action and Between Facts and Norms shows, Habermas argues that any group of people have to decide discursively what norms they accept for them. Similar to Fraser's notion of deconstructing traditional identities, Habermas's communicative action (similar to Popper's writing on the open society) provides for a theory of tentative and relativistic definition of democratically legitimated laws cum social norms. 
Fraser (1998) has also pointed to the shortcomings of Habermas's work. According to her, instead of one dominant public sphere, we must rather think of several concurrent public spheres. Furthermore, instead of Habermas's focus on consent, Fraser points to the inherent conflict within each public sphere and between one another. Civil society, under such a light, is a sphere where structural inequalities are played out. However, even bearing this critique in mind, civil societies and public spheres remain the central places bearing the potential to initiate struggles for justice and consolidate new norms and laws. Civil societies and public spheres, after all, bear the potential for freedom from control and coercion, as well as the possibility of a collective and discursive deconstruction of inequalities that have sedimented in our lifeworlds. Reified structural inequalities have a tendency to become "normalized," which refers to their perception as being "normal," "unproblematic," and "natural." As such, they easily escape scrutiny and become institutionalized mechanisms of understanding and making sense out of the world.

This debate points to the need for active public participation, and encompassing and inclusive public discourses leading eventually into a gradual solidification and institutionalization, thus becoming law. In this view, which is indebted to Emile Durkheim, laws are institutionalized traditions. They are democratic if and when all those sectors of society living under the law have had an opportunity in the formative phase of the law, by participating in the discourse that produced a widely accepted and hence legitimized common sense and a practice that is reflective of this common sense.

Hence, Habermas and Fraser leave us with an analytical framework that allows us to assess and judge the legitimacy of laws, as well as the problems arising when laws do not reflect social realities. Applied to the case of Colombia, it quickly becomes clear that one of the main problems with the new legal frameworks created in 1991 and thereafter is rooted in a lack of popular involvement in the process of their emergence-this, I argue, despite the constituent assembly held in 1991 that drafted the new constitution. To use a somewhat exaggerated language, this chapter argues that the new Colombian constitution did not really emerge from below, despite the constituent assembly, because important sectors of the population, such as Afro-Colombians, did not participate. 


\section{LAW AND REALITY IN LATIN AMERICA AND COLOMBIA}

Colombia, just like the rest of Latin America, firmly stands in a Roman legal tradition and adopted the Napoleonic Civil Code as the base for organizing civil, commercial, and penal law. For Francisco Moreno, this means that "The acceptance of Roman law and its implicit philosophical bases determined the direction of Spanish political thought and institutional development. The idealism and universalism which had found judicial and political expression in the Ius Honorarium, Ius Naturale, and Ius Gentium became an integral part of the Spanish way of thinking" (Moreno 1969: 4). Moreno further explains that

Law was for the Romans, above everything else, a moral interpretation of lifean effort to define those ethical goals that the political community should strive to attain. The works of Cicero, Seneca, and the later Roman lawyers suggest examples of this interpretation of the legal function. Law became an attempt, based upon abstract ethical reasoning, to determine how people ought to behave. (Moreno 1969: 7)

It is this tradition that to this day determines the outlook on laws in the Latin world. Under this tradition, laws do not reflect reality as it is-they rather represent how the social world should be ordered. In colonial contexts, this tradition takes on yet another, complicating aspect, as it raises the question of who it is that "imagines" the social order of a country in such a way.

As we have argued elsewhere,

Latin America ... inherited a tradition of code law rooted in the legal practices of the Roman Empire and spread across the globe by Spanish and Portuguese colonizers, which is deeply marked by legal idealism. Legal idealism characterizes a system where laws are created and codified by elites, who take little interest and are indeed unfamiliar with the reality of the majority. Under such circumstances, legal codes do not necessarily articulate the consolidated practices and norms of "the people." Rather, they represent the definition how a society ought to organize according to societal elites; and they thus contain an inherent paternalistic and antidemocratic trait of elite-tutelage. (Nef and Reiter 2009: 43f)

In the case of Colombia, the answer to this question was clear before 1991, as the previous constitution was enacted in 1886 and thus firmly represented the imaginary and legal cunning of the country's Europhile 
elite. Explains Lynch: "Once the codification movement did take hold in the 1850's, it was still isolated from the realities of Colombian life. . . . It was enacted with little or no debate even though it was based on a Spanish Code of 1829 drafted for a very different social and economic context" (Lynch 1981: 31). Lynch further finds that "This isolation of the codification movement is another example of the tendency to import European political and legal forms in an effort to pattern the formal character of the Colombian state after the European metropolis" (Lynch 1981: 32).

According to Robert Means, "A certain degree of isolation is a natural part of codification in the civilian tradition because of the relative autonomy of that tradition's intellectual structure. But the disparity in development between Colombia and even relatively under-developed European countries like Spain magnified the isolation in two ways. The first concerned the number of persons for whom the code had any relevance. ... The second concerned the proportion of the new code that was relevant to anyone" (Means 1973: 22f).

This legal tradition continued to influence the ways legal frameworks developed all the way into the twenty-first century. During the early twentieth century, according to Lynch, "the dominant trend in the legal order remain[ed] the continuation of the codification process. New codes were enacted to facilitate the expansion of private corporations and, more recently, to increase government control over the use of corporate capital" (Lynch 1981: 33). During the 1960s, finally, the Colombian state reformed several of its legal codes, giving more power to the executive (Lynch 1981: 34).

In general, Colombia, just like the rest of Latin America, confronts a situation where the law stands in isolation, or even in opposition, to reality. According to one analyst, "The typical problem of the 'peripheral modernity' in regard to the allopoiesis of law amounts to the weakness, irrelevance as well as the absence of the constitution as a structural coupling of politics and law, a mechanism that makes a legal solution of the self-reference problem of the legal system possible. The political takes precedence over the legal so that one can hardly speak of operative autonomy or functional differentiation of both systems" (Neves 2001: 260). The same author, who is a legal scholar specializing in Latin American legal traditions and philosophy, concludes his diagnosis of contemporary constitutionality in the region thus: "There is a scandalous divergence between the constitutional model based on democratic principles and rule of law, on the one hand, and political and legal practice, on the other hand" (Neves 2001: 260).

In the case of Colombia, with the expansion of executive power came the growth of clientelism. According to Lynch, "The most important trend 
in the political sphere has been the increase in government planning and the use of regulatory law to control the economy. At the close of the nineteenth century, the government had become a caretaker state primarily concerned with maintaining order and enforcing a set of rules designed to facilitate private economic agreements. The two major parties competed for control over the public bureaucracy as a source for jobs, money, and status. The party in power used the public treasury to reward its faithful with jobs and manipulated the capital investment of government funds to their advantage" (Lynch 1981: 35f).

Clientelism is alive and well in Colombia, as Agudelo (2002) has recently demonstrated. According to Agudelo, after 1988, when mayors started to be elected directly, the system of "a vote for a favor" grew. Explains Agudelo: "Now that the population had a much more direct mechanism to approach a politician in the midst of their great needs for services and employment, the interchange of votes for tangible material benefits accelerated" (Agudelo 2002: 178). The question then is: how much of a break does the new constitution of 1991 represent? The very procedure that produced this new constitution is suggestive. The constituent assembly came together in February 1991 and after five months of deliberation produced the new constitution, which became effective in July of that same year. The population elected seventy delegates to the assembly. In addition, and in order to seal the peace agreement with different armed forces, four delegates of previous guerilla movements also participated in this process, although without the right to vote on the final draft. However, the different factions of the until-then very loosely organized Colombian Black Power movement were unable to overcome their internal divisions and settle on one candidate to represent their interests in the assembly (Agudelo 2002: 182). An indigenous leader (Francisco Rojas) represented the interests of the black community, raising this issue on the last day of the meeting.

However, even if the Black Power movement had been able to be more present in this process, the outcome, I suspect, would not have been much different. This can be seen when comparing the Colombian case to other, similar processes in the region. In Brazil, for example, even though popular segments participated in the drafting of the 1988 constitution, popular participation did not bring the law closer to reality. If anything, some elements of the 1988 constitution are even more utopian, leading Roberto Campos to the conclusion that "The Constitution of 1988 promised us a Swedish social security with Mozambican resources” (Revista Veja, October 8, 2008, my translation). 
Despite the polemic tone of this statement, made by a right-wing economist and politician, the problem he points out is very real. Social inequality, after all, cannot be legislated away, especially when mechanisms and resources able to actually bring such a desired new reality about do not accompany the new legal frameworks. It is thus not surprising that the anything-but-right-wing Colombian writer Gabriel García Márquez reaches a verdict about the relation between law and reality in Colombia similar to the one voiced by Campos in and on Brazil. Says Márquez: "I believe that we are acting, thinking, conceiving and trying to go on making not a real country, but one of paper. The Constitution, the laws . . . everything in Colombia is magnificent, everything on paper. It has no connection with reality" (quoted in Pearce 1990: 11).

The Colombian constituent assembly, as well as the ones in Brazil and other Latin American countries that have recently enacted new constitutions (such as Bolivia and Ecuador) thus all followed the French revolutionary model by focusing on changing legal frameworks in order to overcome deep-seated political and social problems. Doing so, they attempted, in the words of Moreno, to "legislate problems out of existence" (Moreno 1969: 9) without being able to establish, let alone guarantee, the necessary enforcement mechanisms that could actually bring about these realities and bridge the gap between legal normativity and social reality-or facticity, in the words of Habermas.

Such laws do provide political opportunities (Tarrow 1994) for historically marginalized populations to organize and mobilize-a phenomenon we have been able to witness amply, as the new legal frameworks did indeed lead to increased levels of black and indigenous contentious organizing, and even to the emergence of new leadership among this segment of Colombian society. However, the same is true for the historically dominant segments of Colombian society. To them, the new constitution and Law 70 also provided ample political opportunities.

By passing beautiful laws and signing international conventions that are then either not enforced, or actively violated, the Colombian government is able to garner international legitimacy and thus substitute it for democratic internal legitimacy. The structural problems of this country-elite domination and concentration of landownership-have not been addressed and remain in place. The legalization of the political aspects of citizenship in a world where access to the law is a privilege of the few means that traditional, conservative political and economic elites have not much to fear from an independent judiciary, because they know that the poor have no access to the law so that they can actually make it work for them. There are very few 
lawsuits brought forward by historically excluded groups—and even fewer lawsuits won. Where people and groups pressure the government to enforce the law, they are intimidated and their lives are threatened by the executive arm of the elites - the paramilitary groups-as in the case of the current president of the Association of Displaced Afro-Colombians, AFrodes, whose life has been threatened several times since she started advocating for the fulfillment of the human rights anchored in the Colombian constitution.

Instead of political power, Afro-Colombians now have laws like Law 70, but they do not find much support to actually enforce it, as both the executive and legislative branches of government remain under firm elite control and are opposed to changing the status quo. Colombian citizenship has thus become even more legalized and less political. ${ }^{6}$ Effective citizenship in such a system critically depends on access to the legal system-"the right to sue and be sued," according to Pocock. This right, however, is distributed very unequally in Colombia, as elsewhere in the region, where access to the legal system has remained an elite privilege. Castoriadis's words come to mind: "The 'executive' power does not execute anything; it decides and governs. It is bailiffs and secretaries who 'execute.' The 'executive' power is in reality the governmental power; it makes decisions that are predetermined by no law. It does not 'apply' the law; it acts within the framework of the laws, which is something else entirely. Its decisions are, in the major cases, discretionary and without remedy" (Castoriadis 1990: 214f).

The missing element in Afro-Colombian empowerment is the political. Because of their political weakness, Afro-Colombians pose no real threat to the interests of traditional elites, who firmly control the executive and legislative branches of government - and have been able to use the independence of the judiciary in their own favor. Wherever Afro-Colombians have challenged their exclusion from the political, then traditional elites, who control not only the government but also the state and the very definition of what "political" means and who has legitimate access to this realm, have struck back violently in order to uphold the system. The effects of the political weakness of Afro-Colombians are made worse by the relative weakness of the Colombian state-an argument that requires some further scrutiny.

\section{WHAT IS A WEAK STATE?}

Once such a new legal framework is created, the inevitable question becomes: what is done for this law to become reality? Colombia's state has 
historically been too weak to even fulfill the minimum requirements that give states their very definition, namely, the control of violence in a territory. Several nonstate actors, mostly guerilla movements, have long and successfully disputed control over several parts of the Colombian territory. With the proposal of the Plan Colombia by President Pastrana in 1998, and the significant financial support received from the United States with its advent, the Colombian state was able to significantly strengthen the executive branch of the state, together with the military. However, the very strong military bias of this support has led not to an equal strengthening of the Colombian state, but to a one-sided growth of the military and the executive branch of government. Strengthening the law-enforcement and military capacity without strengthening the legislative and judicial components of the Colombian state has done nothing and maybe even contributed to a further erosion of the legitimacy of the Colombian state. A strong state, as Hillel and vom Hau (2008) have recently argued, cannot be reduced to the power of the executive or the military. We know at least since the work of Max Weber's Economy and Society, first published in the 1920s, that for government to work successfully it needs to rely on the willing compliance of the citizenry. Reinhard Bendix, who followed Weber's analysis while examining changing social orders and how they relate to nation-building and citizenship (Bendix 1969), has thus argued that "While governments vary greatly with regard to the subordination they demand and the rights they acknowledge, the term 'political community' may be applied wherever the relations between rulers and ruled involve shared understandings concerning this exchange and hence are based in some measure on agreement" (Bendix 1969: 23). Bendix has summed up this insight by stating that "Ultimately, it is a question of 'good will' whether the laws and regulations of political authority are implemented effectively by the officials and sustained by public compliance and initiative" (Bendix 1969: 23).

In short, and following both Weber and Bendix, it becomes clear that "effective authority thus depends upon cumulative, individual acts of compliance or confidence" (Bendix 1969: 24). This argument receives much empirical support from the experience of the successful city government of the Colombian capital, Bogotá, under the mayor Antanus Mockus (January 2001 to December 2003). As Mockus (2009) explains, it was through instilling in the population a sense of admiration for the law coupled with a fear of legal sanction, together with the establishment and dissemination of moral codes of conduct and the creation of a social environment of social trust and control, that the city of Bogotá was able to successfully combat the then-rampant crime, disregard for the law, and general disregard of anything 
relating to the government and public life. By focusing on legal norms, moral norms, and social norms, the Mockus administration was able to significantly reduce homicide rates from a peak in 1992 of 80 homicides per 100,000 inhabitants in the city of Bogotá to 23 per 100,000 in 2004 (Mockus 2009: 143). Due to increased voluntary compliance with traffic regulations, Bogotá also experienced a reduction of deaths in traffic accidents, which went down from some 24 per 100,000 during the 1990 s to 8.6 in 2003 (Mockus 2009: 145).

In general, however, the Colombian state has not made the kinds of investments in citizen trust and voluntary compliance that Mockus initiated in Bogotá in 2001. To the contrary, the widespread sentiment among Colombians towards government is one of well-founded distrust, which then produces a pattern of seeking to replace the logic of the public with the private logic of personal dependence. As Brazilian anthropologist Roberto da Matta (1987 has explained, where the state is not trusted, people end up betting on personal-trust relationships, which then leads into systems of patrons and clients-the proverbial clientelism. Even though da Matta writes about Brazil, his analysis equally applies to other Latin American countries that have inherited Iberian legal traditions and associated behavioral codes. Da Matta explains how for most Brazilians, the very notion of the state and the law it represents implies something negative. $\mathrm{He}$ quotes a popular Brazilian proverb that says, "For my friends, everything; for my enemies, the law!" (da Matta 1987: 319). Furthermore, da Matta finds in an empirical study among Rio de Janeiro residents that to most, following the law is considered a stupid thing to do. Indeed, most people interviewed by da Matta considered those obeying the law idiots (da Matta 1987: 318). The general point that da Matta makes is that being a citizen is a social role that not only needs to be learned, but also oftentimes holds negative connotations - at least among the Rio de Janeiro inhabitants he interviewed during the late 1980s. Da Matta comes to the conclusion that "Citizenship as a social role is not experienced in this manner in daily life. In effect, the word 'citizen' is always used in negative situations in Brazil to demarcate the position of someone who is at a disadvantage or inferior" (da Matta 1987: 317).

It is this negative association with rules, laws, and being a citizen in general that Antanus Mockus sought to change while serving as mayor in Bogotá. The Colombian state is thus weak not only because it lacks resources and capabilities; it is weak because its citizens do not have enough trust in its functioning to voluntarily comply with the existing laws and regulations. A weak bond exists between the state and its citizens-something that should 
not surprise anybody aware of a history of elitism and corruption that has long defined the Colombian government. In Colombia, this situation is worsened by its history of elite pacts, known as the "National Front," which secured power to the two predominant parties for decades, blocking the access of popular interests to the state apparatus. Where states are controlled by elites, and citizens feel that the state is not truly theirs, alienation and lack of compliance are inevitable.

Furthermore, the weak Colombian state also lacks autonomy from societal elites-so that social hierarchies spill over into the political realm and transform the state into an instrument of societal elites. In Colombia, traditional elites have had such a firm grip on the state that oppositional groups were pushed into illegality, thus forming guerilla movements. As a result, Colombians are confronted with strong elites, able to control the state apparatus and use it in their own interest; a weak bond between the state and its citizens, thus leading to reluctant voluntary compliance; and-in the case of Afro-Colombians-a social group that is unable to garner enough political power to oppose the hegemonic societal forces that control the Colombian state.

Under such conditions, crafting new, beautiful laws becomes just another superficial state maneuver with little or no real consequence. To make matters worse, a history of at times camouflaged racist practices has further weakened the bond between citizens and the Colombian state. It has also produced a social reality, or fact of extremely unequal lives in Colombia, keeping Afro-Colombians and indigenous people at the very bottom of social, economic, and political hierarchies. The Colombian way of racial exclusion thus deserves some further scrutiny.

\section{RACISM IN A DERACIALIZED SOCIETY}

As I have argued above, the final factor impeding substantial positive changes for the black community living in the Colombian Pacific coast is the prevalence of discriminatory practices, or simply "racism." Racism in a formally and officially raceless society takes on a particular form that warrants more detailed explanation. Colombia has only recently, and only formally, admitted to its multicultural population, but such an admission is a small step towards actually acting on behalf of historically excluded groups. For most of its history, Colombian elites have fought to suppress their own native and African populations in an effort to wipe them out of 
collective imageries by making them invisible (Friedemann 1984). This effort goes back to the very beginning of independent Colombia as the declaration of independence also proclaimed de jure equality of all citizens. De jure equality, however, did not translate into de facto equality, and slavery remained legal until 1851 . After independence, the predominant way to "deal" with the black and indigenous populations of Latin America was by constructing and disseminating the myth of racial democracy, which allowed elites to block the formation of racially based associations that could potentially formulate group-specific grievances. Marixa Lasso (2007) shows how the first two decades of independence were crucial for the construction of this myth, and how at the end of the successful construction and dissemination of the myth, and by linking it to patriotism, "the explicit expression of racial grievances became a mark of unpatriotic divisiveness" (Lasso 2007: 13). Because of its relevance, I will take a closer look at this symbolic construction of racial democracy in Colombia.

Proposing-or "imagining," in the words of Benedict Anderson (2006) — the myth of racial democracy provided Latin American elites with a powerful way to escape the racial determinism that dominated Western intellectual circles during the early nineteenth century (Skidmore 1993). According to Anderson, "It is imagined as a community, because, regardless of the actual inequality and exploitation that may prevail in each, the nation is always conceived as a deep, horizontal comradeship" (Anderson 2006: 7). Similar to the passing of laws that do not entail real change in the 1990 s, proposing a way to think of and represent the nation as a community of equals was a way to block the de facto formation of political cleavages able to press for real change in the early eighteen hundreds. This strategy offered the additional advantage that it allowed Latin American elites to escape a racial determinism that implicated them vis-à-vis their North American and European models. As Nancy Stepan explains, "To a large extent the educated classes of Latin America shared the misgivings of the Europeans. They wished to be white and feared they were not" (Stepan 1991: 45). White immigration and whitening became the two tools of Latin American elites everywhere to achieve the kind of modernity that they knew of-one that was European and white. In Colombia, as Lasso shows, "in the early decades of the nineteenth century, the newly independent Spanish American countries decreed racial equality among free men and constructed powerful nationalist notions that linked racial harmony and equality to national identity" (Lasso 2007: 34).

During the years of struggle for independence, Colombian elites needed Afro-Colombians in order to gain numerical strength during the 
independence negotiations in Cadiz, and then to fight back the Spanish colonizers - yet they also feared the Afro-Colombians' upward mobility, and the threat to white privilege that such mobility implied. Instead of offering real political and economic change, which would have meant sharing some of the very tangible benefits that their status secured them, Colombian elites offered de jure equality - as early as in the first constitution of Colombia, ratified in the newly independent Cartagena, then an independent republic (Muñera 2008). "The 1812 Constitution eliminated legal color distinctions; guaranteed suffrage to all free men but vagrants and servants; and, although it did not abolish slavery, outlawed the slave trade. In addition, pardos of modest origin became members of the constitutional assembly, the war council, and the parliament" (Lasso 2007: 78).

However, after using the black masses for political support, and to justify splitting from "despotic Spain" in the name of liberty, Creole elites feared losing control over those masses and gradually grew afraid of nonwhite political participation. Creole elites struggling to maintain control after 1812 invoked fears of a new Haiti and a race war, which ultimately led to the expulsion of black republicans from the Cartagena congress. Once AfroCartageneros had fulfilled their political function, white Creoles initiated a process of gradually marginalizing them from the collective memory by stressing white Creole heroism and denying black participation. For Lasso, "Creole patriotic history thus made raucous bandits of Afro-Colombian patriots" (Lasso, 2007: 86).

This new framing associated lower-class participation with disorder. When Spain again became a threat, and while Creole elites again had to call on black military participation, Cartagena race relations entered a second phase. As Lasso explains, "By the time the independence struggles were over [1824], several pardos had become officers - even generals - in the patriot army. The question now was what role these men would play in the new republic" (Lasso 2007: 90).

The answer to this question became clear when white elites voiced their concerns about a "pardocracy" and associated the voicing of racial grievances with the fear of an impending race war and the potential dawn of another Haitian Revolution. As Lasso explains, rumors of race war emerged whenever blacks seemed to threaten white privilege by ascending to powerful positions (Lasso 2007: 138). The invocation of the race-war rhetoric thus served to block black social mobility, and openly addressing the topics of racial inequality and racism had dire consequences for the accusers. Lasso finally explains that "Once they had been declared unnecessary, racial grievances became dangerous attempts to disrupt public order" (Lasso 2007: 143). 
It appears that whereas in 1812 Cartagena the call of the day was for "one people, one nation," in 1991 it was the official recognition of multiculturalism that allowed traditional political elites to defend their entrenched positions of privilege by invoking and codifying paradise, while perpetuating hell (Wade 2001 and 2005).

In 2005, fourteen years after Colombia became officially multicultural, the infant mortality rate among Afro-descendants remained almost twice as high as that of the rest of population: 48.1 percent and 26.9 percent per 1,000 live births respectively. Life expectancy for Afro-Colombians in that year was 66.4 years, while for the rest of the population it was 72.8 years. Despite the laws and legal codes passed in 1991 and the following years, reality for the poor and excluded continues to look anything but bright. Structural racism has cast such a strong shadow on Afro-Colombians that even in the Chocó department, progressive forces have not been able to win political power-even though there are significant community structures, such as the community umbrella organization Cocomácia, representing 124 consejos comunitarios in the Medio Atrato region, and a supra-umbrella organization called Foro Solidaridad Chocó, which represents 64 community umbrella organizations and covers the entire Chocó department. Racism in Colombia thus has undermined the political power and autonomy of AfroColombians, who have not been able to forge enough group solidarity to win political control even where they are the absolute majority.

It becomes clear that racism cannot be overcome by legal frameworks alone. Concrete measures must be taken that actually address the economic and political positions of nonwhites in racial hierarchies. This is a far cry from what Colombian political elites have done over the past years.

\section{CONCLUSION}

This chapter has sought to demonstrate that by adopting a new constitution and signing several international agreements on the situation of black and indigenous people, Colombian elites have been able to address the problems of racism, violence, exclusion, and displacement vis-à-vis the international community, thus gaining in legitimacy and securing international support and continued aid. Upon taking a closer look, however, it appears that those elites have done what they have always done in the past: they have proclaimed change without providing the means for this change to actually become a reality. For all those at the bottom of social and racial hierarchies, 
not much has changed in their situations of marginality—only that now the elite-dominated state has shielded itself from any criticism from below. Afro-Colombians continue to live in Mozambique, but now under a Swedish constitution - to use the metaphor of Roberto Campos (quotes above). To explain this, I have highlighted three causal mechanisms-namely, the weakness of the Colombian state, the legal tradition of Colombia, and the persistence of racist practices and a racist common sense. The term "weakness" actually stands for more than one phenomenon in that it indicates a lack of state autonomy, a weak connection between state and citizens, and finally a lack of state capabilities. All three are relevant here. The tradition of legal idealism, in turn, is not something that characterizes Colombia alone; Colombia is but one of many countries that follow this tradition, which influences how citizens and political elites envision social change. While it is certainly true that because of Law 70, Afro-Colombians have become recognized political actors, the whole definition of what counts as political, and how citizenship is operated changed precisely when these new legal frameworks became available. In a very similar fashion to the cases already analyzed, Colombia also provides evidence for the tradeoffs between the strength of rights and their exclusivity: once some groups claimed access to the political, thus challenging the traditional divisions of power that pushed them into the realm of civil society, they were confronted with new strategies designed to block their access and the effectiveness of their claim-making.

Finally, the engrained practice of racism also characterizes other countries beyond Colombia and has actually been described in more detail for such countries as Mexico and Brazil. Together, these three composite, and hence rather complex, causal variables produce the outcome we can readily observe, namely, that social reality for Afro-Colombians has not changed significantly despite changed legal frameworks. 


\section{Conclusion}

\section{Learning from Exploratory Research}

THE EMPIRICAL CASES EXPLORED ABOVE, ANALYZED UNDER THE FRAMEwork of what they can each tell us about the different aspects and dimensions and the internal contradictions, or dialectics, of citizenship, have fleshed out several insights that allow me to summarize some "lessons learned" in this chapter.

\section{DIALECTICS}

The first insight is about dialectics. So far, thinking about inherent contradictions and unresolved tensions of citizenship has proven fruitful. Not just because such a way of thinking is inherently dynamic and allows us to focus on processes rather than stasis. Given that the social world is in constant flux, such a way of thinking about it promises to produce fruitful research questions, designs, and hypotheses to be explored and tested. Contrast and comparison is indeed the main way in which we are able to create hierarchies and value, so that dialectics is not just a way of thinking, but also appears to have an ontological status, as our efforts to categorize, sort, order, and finally hierarchize end up reflecting back on the world, structuring it. Any good social science, I am tempted to say, needs to be dialectical to some extent and focus not only on the relationship between structure and agency, but also the relationship between form and content. When it comes to social hierarchies, forms become contents. Contradictions are an integral part of social reality, and we should not, as social scientists, try to explain them away in our quest for patterns, regularities, and parsimony. 
Instead, social-science analysis should focus directly on the nodes and breaking points where contradictions are manifested. Those places tend to be the most revealing and telling, and an analysis of those crucial cases promises to shed light on much more than the case analyzed. Only dynamic historical models about reality can capture this phenomenon.

\section{CITIZENSHIP DIALECTICS}

Citizenship, wherever and whenever one looks, has borne inherent contradictions. By providing rights, it has denied them to others-either excluding them altogether, or making them second-class citizens. As the analysis of ancient Athens shows, this is not a phenomenon caused by capitalism. Instead, it seems rooted in the very human strife for distinction and privilege, which uses whatever capital it has to its advantage: financial and symbolic. Money and power are thus put in play not against, but withand to strengthen - the effectiveness of other capitals: social, cultural, and racial. In all of this, whiteness is a formidable symbolic capital —even in those places where it does not exist as a phenotype. African and Indian elites still seek to produce and justify their privileges with reference to proximity to whiteness, Europeanness, or the other derivates that contain and transport the same values, such as liberalism, progress, or civilizational advance. As we have also seen in the chapter on Athenian democracy, it was once believed that it is the proper task of politics to find ways to neutralize and counterbalance the inherent and apparently very "natural" human tendency to strive for privilege.

When thinking about citizenship, one is thus well advised to think about its inherent contradictions-even more so if one seeks to not just think about, but analyze citizenship. When doing so, one should always remember that "citizenship" is but a word and a category-and that the realities it represents are complicated, multifaceted, entangled, and disorderly in the extreme. Our theorizing and analyzing can only shed light on very limited aspects of this always-changing reality-but in doing so in a structured way, we can make better sense of reality and discern better what causal mechanisms are potentially at work, so that we can avoid some of the obvious pitfalls and instead strengthen the promising potential of a reality we constantly reproduce and reshape in our social interactions. 


\section{EXPLORATORY, INDUCTIVE}

\section{RESEARCH IN THE SOCIAL SCIENCES}

This book has also demonstrated, I hope, what exploratory social-science research can accomplish and under what conditions. As I have explained at the beginning of this book, pure "discovery" is impossible to us, because as human beings, we share the cultural frameworks, or lifeworlds, of those we seek to analyze. We should not pretend otherwise, and instead should be as honest and transparent as possible about our own situatedness, social place, and limitation. This, I realize, is much to ask from most "professors"-but it is the only way to actually produce objective knowledge.

Exploratory research still needs to start from a hypothesis, and from there expand the researcher's understanding of all the factors that influence and produce the hypothesized outcome. Research must thus aim at closing the hermeneutic circle. To do so, a clearly formulated starting position is needed. In this respect, much can be learned from "taking Popper seriously"- but it also becomes clear that Popper's high standards are not suitable for the social sciences. There are not paradigms and there never will be, as the social world is one of constant change, constituted by meaningful social interaction that requires constant interpretation to reach even partial understanding. Thus we operate one level below Popper's high ground, and on that level induction is not only possible, but plausible and desirable. What we should aim for, then, is structured, self-aware, self-critical, and self-conscious anticipation, which is followed by testing for plausibility, illustration, and exemplification.

It is in this sense that the cases presented above do not constitute a comparative case study, or an attempt to confirm a hypothesis through a most-similar case study. I do not want to argue here that such a thing is impossible. To the contrary, as the excellent work of such scholars as John Gerring (2007) and Alexander George and Andrew Bennett (2005) has recently demonstrated, such an endeavor is possible and indeed very promising.

Exploratory research, in contrast, uses cases to demonstrate the usefulness of a previously formulated model. It then proceeds by applying this model in such a way as to produce as much insight into a given case as possible. Hence, it does not compare cases, but rather explores each one of them to the maximum. The rationale for case selection accordingly is one of choosing the most telling or richest cases - that is, cases where the causal mechanisms previously stipulated are manifested in the clearest way. This can mean that the causal mechanisms under scrutiny have produced the strongest impact; but it can also mean that they are easiest to describe 
and hence very illustrative. Exploratory research thus looks for telling, rich, and illustrative cases in such a way that each case reveals as much as possible about a causal mechanism that has been previously formulated in an explicit model or theory, and has led to the formulation of clear and precise hypotheses. I hope that this book has demonstrated the potential of such an approach.

Beyond the epistemological and methodological insights that this book has sought to present, the empirical cases discussed in each chapter all have produced important insight into the dynamics and dialectics of citizenship in its articulation with democracy, exclusion, inclusion, and such related social phenomena as the racialization of some groups in this process. In the remainder of this chapter, I will bring the different insights together, thus providing for an overview of the factual "contribution" of this book about the dialectics of citizenship.

\section{COLONIAL ENTANGLEMENTS}

The cases of France and Portugal clearly demonstrate that the same mechanisms described and analyzed for Brazil and Colombia also structure citizenship elsewhere. France and Portugal stand at the other side of the colonial entanglement they created. There, too, some citizens are deemed less worthy than others, and the mechanisms by which this exclusion is produced are very similar to those applied in their former colonies.

From Portugal, we can learn how the colonial legacies produced during five hundred years of colonial enterprise have started to cast a shadow on postcolonial Portugal. Portuguese colonizers sought to secure their privileges through the power of the colonial empire they represented, and by making strategic use of their skin color to justify their privileges as colonizers. After independence, the former colonizers brought this knowledge of how to secure their privileges back to Portugal, where they were able to get the state behind their cause. White African immigrants were recognized as "returners" and treated differently from black "immigrants." The complacence, and indeed collaboration that the Portuguese state has shown these returners gives important lessons about state roles, and how some groups are able to use the state against others. The resulting framing of nonwhite citizens as foreigners and immigrants also shows the role that other elites-particularly academic — can play in this process. By changing its naturalization laws, Portugal indeed joined the European mainstream of 
replacing ius solis principles to regulate citizenship with the now dominant ius sanguini principle, which regulates rightful belonging by descent.

Portugal thus provides important insights into the intersections of citizenship with nationality, and it sheds light on how both of these ordering principles were created, reformulated, and changed by state elites in order to accommodate postcolonial realities.

Similar lessons can be learned from the French case, where states are equally dominated by traditional elites who seek to defend the interests of their traditional, majoritarian electorate by not providing any means for second-class citizens to mobilize, organize, and formulate grievances. In this, the French case is paradigmatic, providing the blueprint for other European states and governments. However, France is such a rich case that it is able to also shed much light on the whole liberal tradition it represents.

\section{LIBERALISM DISMANTLED}

The French case indeed shows that the liberal tradition, together with the universalist ideals such a focus on individual rights necessarily entails-all of which this country so proudly claims for itself-was indeed hollow and exclusionary from the very beginning. Colonials, women, the poor, and the educated were never included in this vision of "all men being equal." The attitudes against Africans and their descendants provide one of those pivotal nodes of analysis that tell us much about the general workings, depths, and breadth of such lofty ideals. In practice, all nonwhites were relegated to the realm of non-men, thus nonhumans.

There is no clearer place to observe this than in the French colonies. There, French liberalism revealed its own inherent contradictions. And while I am aware that it is "unfair" and not "scientifically" sound to apply contemporary criteria of justice to the analysis of times way past, the absolute negation of nonwhites by European thinkers and statesmen clearly demonstrates how exactly Europe achieved its worldwide supremacy-namely, by embracing and disseminating the myth of their own, racial, superiority. That this enterprise was so successful attests to the power and vehemence of the European war and colonizing machine, as well as to the attractiveness and fatality of the capitalist market system it brought with it and symbolized. It is fair to say that no corner of this world was left untouched by it, so that racialized social hierarchies transported, sold, and disseminated under the mantle of liberalism, universalism, and progress are now present 
everywhere- - even if, in their local declinations, finding expression in different local schemes of hierarchizing positionalities.

\section{LAW AND REALITY}

Several authors have highlighted the extreme distance separating law from reality in such countries as Brazil. Such seminal authors as Raymundo Faoro (2001) and Florestan Fernandes (2006) have long explained to us that in Brazil, joining the ranks of the legal profession served first and foremost the purpose of distinguishing oneself by becoming an urban aristocratespecially during the nineteenth and early twentieth centuries. Francisco José Moreno (1969) has argued that Latin America inherited from its motherlands a tradition of legal idealism that found expression in the codification of idealized norms. The essence of this legal tradition resides in the fact that law does not reflect social reality, but an ideal type to which society should aspire. For Moreno (1969), "The lack of correlation between what ought to be and what is, as reflected in the social and psychological patterns of the Roman-Spanish tradition, was transferred to the colonies" (Moreno 1969: 12). Furthermore, according to the same author, "The concern with the abstract concept of justice rather than with the preservation of traditions as sources of law was in Castile, as it was in Rome, a demonstration of ineffective community integration. A society in which customs can be legally superseded by abstract intellectual ideas is one in which past collective experiences are not usually looked upon as a source of identification and security. Such a pattern of legal organization is indicative of a low degree of social cohesiveness. Adherence to ideal formulas is used as an artificial way of providing the social unity and identification that the institutions of the community do not supply" (Moreno 1969: 11).

In the Brazilian case, we can discern a similar pattern to the one discussed by Moreno. The authors of the Brazilian legal codes are those same "men of letters" that Kirkendall (2002) described when discussing nineteenth-century elites as "classmates." Such letrados as Clovis Bevilaqua (who composed the old Brazilian civil code), Francisco Cavalcanti Pontes de Miranda, J. X. Carvalho de Mendonça, Orlando Gomes, and Miguel Reale were Brazilian men of letters par excellence. A jurist, writer, historian, and philosopher, Bevilaqua was the cofounder of a literary journal and was a member of the French Academy in his home state of Ceará. Even though Bevilaqua's civil code, regulating private and commercial life since 1916, was 
finally replaced by a new civil code in 2003 , this new code still represents an ideal, imagined and then codified by men of letters. It is not the outgrowth of the historical experience of the Brazilian people - a people who in 2010 still have on average seven years of formal education. It does not reflect the traditions and habitus of "Brazilians." The same is true for other legal codes, such as the penal code and the constitution-even though the constitution of 1988 for the first time integrated the voice of Brazil's civil society.

In a widely described process of the constituinte, Brazilian citizens were able to present amendments to the constitution, as long as they had gathered 30,000 signatures that were then endorsed by three civil-society organizations. This participative process produced a total of 122 popular amendments and led to a constitution that codified many of the popular demands of the time (such as regular salary increases). However, even though popular segments participated in the drafting of the 1988 constitution, popular participation did not bring the law closer to reality. If anything, some elements of the 1988 constitution are even more utopian, leading Roberto Campos to the conclusion that "The Constitution of 1988 promised us a Swedish social security with Mozambican resources" (Revista Veja, October 8, 2008, my translation).

At the heart of this problem is a Roman-Iberian legal tradition where the few educated legal specialists commit to writing their version of what Brazilian reality should look like. Given the extreme inequalities characterizing Brazil and the very deep alienation of its elites from the average Brazilian people, whose realities they often ignore and sometimes despise, Brazilian law has remained the law of the educated Europhile elites-educated typically in law schools where not the law, but elitist behavior and attitude provided the core of their learning (Kirkendall 2002).

Indeed, a Brazilian federal judge has a starting salary of some 20,000 Brazilian Reais per month—compared to the 2010 minimum salary of 510 Reais and an average per capita income of 668 Reais (Instituto Brasileiro 2010). Antonio Carlos Wolkmer (2003), not without revealing his own entanglements with erudite, Euro-descendant language codes, thus argues that "Clearly, it is in the mercantilist, absolutist, and counter-reformist Portuguese social formation that we can find, even if remotely, the primary factors that produced a political-judicial tradition that is individualistic, erudite, and legalistic. We can thus verify that the imposition and the favoring of the prepositions of a foreign law not only discriminated against a great part of the native population, it also ignored the customary practices of an autochthon law, widely practiced in innumerous indigenous and black slave communities" (Wolkmer 2003: 137, my translation). The same author 
comes to the conclusion that "The structural constitution of this judicial culture helped produce, on one hand, the practice of the 'favor,' the clientelism, nepotism, and cooptation; on the other, it introduced a legality that is undeniably formalistic, rhetorical, eclectic, and ornamental" (Wolkmer 2003: 138 , my translation).

As the case of Colombia has demonstrated, the gap separating law from reality is caused by several factors, legal traditions being just one of them. Governments that are dominated by traditional elites, and states not autonomous enough from elite interests and interference probably constitute the core of this problem. However, Colombia also shows that traditional elite interests can be sidestepped, even if not ignored. Constituent movements and assemblies were able to produce new legal frameworks that in part aim directly at elite interests and cause them much discomfort. And even if the legalization of the political dimensions of citizenship has created much alienation, Colombia also shows that the judicial branch can be a strong ally of social movements and popular demands for justice. The legalization of citizenship, however, provides a formidable obstacle to closing the gap between law and reality, because at the end, this gap is just a manifestation of the much wider gap that tends to separate "the people" from the government and the state.

\section{THE COMMODIFICATION OF CITIZENSHIP}

As we have seen throughout this book, the meaning of citizenship has greatly changed over time. According to John Pocock (1995), in Rome, "citizenship has become a legal status, carrying with it rights to certain things-perhaps possessions, perhaps immunities, perhaps expectationsavailable in many kinds and degrees, available or unavailable to many kinds of persons for many kinds of reasons" (Pocock, in Beiner 1995: 36). It no longer meant what it had in Athens, where "citizenship is not just a means to being free; it is the way of being free itself" (Pocock 1995: 32). Thus it appears that citizenship lost its muscle when it was extended to a greater number of people. For Pocock, the legalization of citizenship conducted under the guidance of the Roman lawyer Gaius (C.E. 130-180) was the beginning of possessive individualism and the rise of "homo legalis"-a person whose rights and political power were defined by the amount of assets he commanded. It was also the beginning of stripping citizenship of its aspects of obligation and responsibility. The more citizenship came to 
solely mean access to rights and entitlements, the more it became subject to the logic of competitive markets, where most assets are worth more if others do not possess them. More than the legalization of citizenship, Pocock suggests that under Gaius we saw the gradual commodification of citizenship, and its transformation into a possession and a good that only the rich and powerful could afford.

Pocock's idea forces us to look all the way back to democratic Athens and the Roman Republic if we want to capture this legalization of politics. It also suggests two important factors that demand attention in this phenomenon. First, we need to analyze the question of how politics and social life relate to the legal system - that is, what the potential consequences of a legalization of the public and political spheres are. Second, if indeed Gaius was the one to codify Roman law and in its vein commodify citizenship, then we also need to consider this process of commodification-when it started, how far it stretched, and what impact it had and has on the quality of democracy.

\section{CITIZENSHIP COMMODIFIED}

As the analysis of those countries with a colonial past has demonstrated, the law and the very constitution of most societies are strongly influenced by its deep social divisions. The formal and official members of its society have defined how Brazilian and Colombian reality should look, and according to which principles it should be guided. The informal segments, the historically excluded, the poor, and the functional or entirely illiterate had no role to play in this idealization. They were instead forced to play by the rules put in place by the elites-a daunting prospect indeed.

The resulting alienation from democracy should not come as a surprise. However, to capture the full picture, one element of this explanation is still missing, namely, the commodification of citizenship per se. Many citizens are not just excluded economically and culturally and made to obey and live under laws that do not reflect their own customs and traditions, they also live in a system where political power to participate and contribute to collective decision making has long been reduced to a set of legal rights. For them, just as for most people living in contemporary democracies, citizenship is no longer characterized by active participation, but by the right to participate through voting and a set of legal protections offered by the constitution. Citizenship has thus been transformed from its original meaning.

As explained above, the core of Athenian democracy thus was that there 
was no clear division between rulers and ruled. Athenian citizens all participated in the ruling of their polity. To ensure that this setup remained in place, Athenians devised several means, such as appointment to office by lot. In addition, several institutions were created for the purpose of avoiding a concentration of power among state officials. The strong commitment to avoid a system where something like a ruling class would emerge becomes evident in many of the formulations Aristotle uses to describe Athenian democracy_for example, when he explains that since some people are not superior to others, "it is clear that, for a variety of reasons, all must share alike in the business of ruling and being ruled by turns" (Aristotle, 1332b12, 1992: 432).

As the chapter on classical citizenship has shown, citizenship in Athens, rather than being a right, instead focused on responsibilities and duties. This was also the case in the Tuscan republics. According to Aristotle, "What effectively distinguishes the citizen proper from all others is his participation in giving judgment and in holding office" (Aristotle 1992: 169). In his famous speech, Pericles also emphasizes the duties and responsibilities of citizenship. According to Manville (1997), "One of the most telling parts of Pericles' speech concerns the relationship between private and public life. The two spheres are several times distinguished (37.1-2; 40.2; 42.3), but a central theme of the orations is the Athenians' perception of the interdependence between the two and the citizen's willingness to transcend the purely personal sphere and involve himself in the matter of the polis."

Hence, in classical times, as well as in the medieval Italian city republics analyzed in chapter 4, citizenship meant a lot to all those who were citizens. It made them power holders and rulers of their own destinies, and it implied and demanded much more than a codified set of rights. Under such circumstances, alienation is virtually impossible, as there is no clear separation between those who rule and those who are ruled. Not so, of course, in Brazil, or any other contemporary democracy where the rulers have been able to set themselves apart from those they rule in sophisticated ways. Whenever the possibility to access and enter the spheres of power become too remote, too unlikely, and when the rulers seem too distant and too different-alienation is likely to result.

Alienation of the citizenry, or a significant part of it, from the state, the bureaucracy, the sphere of politics, and the public sphere are at the heart of widespread discontent with democracy and are ultimately also responsible for its performance being lacking. If people do not feel invested or part of the citizenry, if they feel their opinion and voice is not heard or does not count, if they think that the system is not really "theirs" but controlled by 
elites-then democratic discontent and dysfunction will necessarily result (Tocqueville 2003; Nef and Reiter 2009).

Two factors seem particularly relevant in explaining political alienation. First, exclusion is at the core of this alienation. The Brazilian case has allowed us to deconstruct some of the ways in which exclusion works, providing some insights into the linguistic and formalistic mechanisms used to secure inclusion by reproducing exclusion. These mechanisms certainly do not characterize Brazil alone.

Second, the commodification of citizenship has also contributed to a sense of alienation from politics and the state, where commodification refers to a slow and gradual transformation of citizenship from a regime of rights connected to specific responsibilities to a system of rights as entitlements that are claimable without any obligations, thus taking on an asset character. As assets, rights as entitlements are partly determined by market mechanisms, hence commodified. ${ }^{1}$

This sense of alienation was furthered by instituting representation as the dominant, and indeed hegemonic way that democracies work-both today, but also back when representation was first instituted, in Rome. From the beginning, it appears that representation was not a need, but a tool devised to ensure elite rule, only this time under a democratic disguise. There is indeed nothing democratic about the idea of representation and elections per se, as Castoriadis has convincingly argued:

These "elections" themselves constitute an impressive resurrection of the mystery of the Eucharist and the real Presence. Every four or five years, one Sunday (Thursday in Great Britain \{Tuesday in the United States\}, where Sundays are devoted to other mysteries), the collective will is liquefied or fluidified and then gathered, drop by drop, into sacred/profane vases called ballot boxes [urnes], and the same evening, by means of a few additional operations, this fluid, condensed one hundred thousand times, is decanted [transvasé] into the thenceforth transubstantiated spirit of a few hundred elected officials. There is no philosophy of "representation," though there is an implicit metaphysics; neither is there any sociological analysis. Who represents whom, and how does he represent her? Forgotten without any discussion are the critiques of representative democracy begun with Rousseau, considerably broadened since then, and unreservedly validated by the most superficial observation of contemporary political facts. Wiped out is the alienation of the sovereignty of those who delegate to the delegates. Such delegation is supposed to be limited in time. But as soon as it is instaurated, everything is over. Rousseau was wrong in this regard: the English are not even "free once every five years." For, throughout those five years, 
the alleged choices about what the electors will be called upon to pronounce themselves on will have been completely predetermined by what the deputies will have done between the two elections. These five-year terms obviously have cumulative effects, and the "choice" of the elector finds itself reduced to such grandiose dilemmas as François Mitterrand or Jacques Chirac, George Herbert Walker Bush or Michael Dukakis, Margaret Thatcher or Neil Kinnock, and so on. And as soon as a small separate political body exists, it cannot help but look after its own powers and interests and enter into collusion with the other de facto powers that are set up within society, notably economic ones. (Castoriadis 1990: 211ff)

Indeed, the study of Rome has shown that the shift towards representation by societal elites was not a necessary move, but a political maneuver. True, ensuring the direct participation of great numbers poses a challenge, but this challenge is one of logistics and institutional design and could be solved for better or worse- if the political will to ensure self-rule and autonomy would have carried the day. It did not. Self-rule and autonomy were instead stolen away from the people, and it appears that the trickery used to achieve this final goal was not obvious to ordinary people.

Representation is what we all ended up with as a political legacy and tradition, even if it was contested again and again (e.g., by the medieval burghers and French-Caribbean revolutionaries analyzed in this book, but also by all those seeking to establish "Räte Republics" after the first World War).

Citizenship was pushed out of the political realm into the legal realm, thus transforming it from a right to rule, to a right to sue and be sued. This transformation happened early and went hand in hand with the transformation of direct rule into rule by representation. At the end of this development stands the situation we know now: ordinary people talk of the state, government, and even politics from the outside. They are alienated and no longer feel that they are the state and that the government is truly theirs.

This change is not one of quantity, but of quality, as the very character of what it means to be a citizen has changed in this transformation. Ever since this transformation, ordinary people belong to civil society. Liberalism, with its claim to privacy, only becomes possible once the people have left the political realm. This diagnosis is opposite to the one offered by Agamben (1998), who claims that biopolitics have absorbed humans to the point of total control, whereas in ancient Greece, humans were thought of as political animals, and $z o e$ was differentiated from bios. From the point of view of state power and control, this might be true. However, from the point of view of 
citizens and their relationship to states, the opposite seems the case: citizens gradually lost their belonging to the state and the political realm. Politics has become an elite business, conducted by specialists. Democracy no longer is a system where the people rule themselves. In the midst of this change, people's lives have become fragmented, and more and more emphasis has been given to the private realm-the realm of civic organizing, but also the realm of consumption, entertainment, and distraction. Civic organizing is only required once genuine political participation is no longer a possibility and ruling has been handed over to elites. Civic organizing and the kind of associationalism that Tocqueville heralds is indeed a weak and insufficient substitute for true political participation and self-rule. The alienation from the political also seems to find its reflection in the courageous civic activism of many, but also in the tremendous consumerism so prevalent today. Both seem motivated by a seeking of meaning, as well as a channeling of creative energy — all of which were once integrated into political life.

Even the critique that direct democracy seems too time-absorbing and burdensome appears in a different light when analyzed under the lens of lost self-rule: where participation is meaningless and overshadowed by powerful players from government or private business, participation becomes indeed tiresome and meaningless. This is the lesson from the participative budgeting processes initiated during the mid-eighties in Brazil: only true and effective participation can keep people involved.

At the very end, I permit myself to venture into the unknown and to formulate some recommendations. The central one certainly is that to reinvigorate democracy, citizenship needs to be reinvigorated. To fight alienation, ordinary people have to participate again — not just as secondary participants, but as central players. Politics has to be reconquered. Their actions should be guided by such slogans as "We are the state" and "We are the government." This goes far beyond the familiar communitarian claims (Sandel 1998), or the substitution of some politicians with "less professional" others (as the Tea Party movement seems to demand). Citizens must not only share in the political responsibilities of self-rule; they must be the ones ruling themselves for democracy's true promise to be realized. Contemporary means of communication offer plenty of possibilities for making this happen-but against it stand all those who have much to lose, and hence do not trust: the people. For "the people" themselves, living in such a system would also imply many changes that would certainly require some time of adaptation and transition, as we now live on top of a huge pile of ideological garbage that we have accumulated ourselves, and we have become victims of the life-transforming powers of elite rule. Our 
energies go wasted into mostly meaningless projects of distraction, consumerism, and "civic activism" that ends up frustrating most of us because it achieves so little vis-à-vis the powers that control politics. A revolutionary step towards self-rule is thus not realistic or even desirable. What needs to occur is a gradual increase of active citizenship, of taking on responsibilities at the local level over community lives. 


\section{Notes}

\section{INTRODUCTION}

1. This diagnosis runs parallel to the currently fashionable analysis of Giorgio Agamben (1998), who seeks to show how states exercise total power over its citizens-even their very lives. However, my primary focus is not states, but citizens, and instead of thinking about the power of states, my questions start at an earlier level: how and why did states become so autonomous from citizens?

2. In this effort, I find myself supported by the call of Uday Singh Mehta (1999) to focus on the "space in-between." For Mehta, this space is the one that binds liberalism and empire tightly together. My own analysis focuses on the pair citizenship/exclusion, of which liberalism and empire form but one subgroup.

3. Chapters 5 and 6 grow out of a previously published article called "Framing Non-Whites and Producing Second-Class Citizens in France and Portugal."

\section{CHAPTER 1. THE EPISTEMOLOGY AND METHODOLOGY OF EXPLORATORY SOCIAL SCIENCE RESEARCH: CROSSING POPPER WITH MARCUSE}

1. This is not to say that all reality is socially constructed, as Searle himself admits. A realist theory of science does not rule out the existence of institutional facts, as Roy Bhaskar (2008), Andrew Sayer (2010), and Daniel Little (1998) have amply demonstrated-it only makes claims about the fact that reality exists independently from our perception.

2. Given this impossibility of pure discovery and induction, the attempts formulated by those authors associated with "grounded theory" (Glaser, Strauss, Charmaz, among others) seem naive- even after they have responded to some of the critiques raised in this regard (Bryant and Charmaz 2010). The same is true for those proposing "iterative research frameworks" (e.g., Srivastava and Hopwood 2009), or even those who have focused on "deviant 
cases," but failed to explain and specify how exactly a deviant case leads to the formulation of a new theory (George and Bennett 2005).

3. Social scientists face a dilemma that sets us apart from natural science. According to Thomas Kuhn (1996), we are in a state of "pre-paradigmatic" inquiry, which means that we do not have broadly accepted theories or paradigms that can be explored to exhaustion. Although I disagree with Kuhn's assessment, I reach the same conclusion, namely, that 100 percent reliable knowledge is impossible to achieve in the social sciences. In contrast to Kuhn, my own assessment rather points to a post-paradigmatic phase-as we already know, and have known for a long time, what the important questions in the social sciences are and how to ask them. Karl Marx, Emile Durkheim, Max Weber, Ferdinand Toennies, Alexis de Tocqueville, among others, have already asked most of them-and given quite good answers. To argue that we are in a pre-paradigmatic phase in the social sciences implies that a paradigm is yet to come-which is not only illusionary, but impossible (Jarvie, in Cohen and Wartofsky 1983). Social life is in constant flux, and fixed laws will never capture it. Most post-paradigmatic efforts, instead of producing frameworks that help to further understand and explain the social world, have instead contributed to creating less clarity and more confusion, some of which seems self-serving, as many analysts seem to engage in efforts to mystify their analyses and themselves. Many social scientists, instead of putting the old questions about power, exploitation, domination, and exclusion to work-which would mainly consist of "working" — seem instead engaged in efforts of self-promotion by proposing ever more "sophisticated" theoretical concepts and models that, if possible, bear their own name and become their brand. In this vanity fair, social scientists only serve their own egos and salaries; they also block an honest and collective effort to analyze the world-a task that can be done jointly with non-academics if the language of the academics is not designed to exclude, but instead to involve (Feyerabend 2010).

4. Hence, even in exploratory and inductive inquiry, Karl Popper's insights apply; namely, that "From a new idea, put up tentatively, and not yet justified in any way-an anticipation, a hypothesis, a theoretical system, or what you will-conclusions are drawn by means of logical deduction. These conclusions are then compared with one another and with other relevant statements, so as to find what logical relations (such as equivalence, derivability, compatibility, or incompatibility) exist between them" (Popper 2002: 9). Where exploratory research departs from Popper's approach is in his stark formulation of the impossibility of induction, which results from his expecting, or demanding, too much from the statements derived from induction. If, however, we depart from a place where certainty is not what we aim for, 
and if we also admit that paradigms are not what we can reach in the social sciences, then induction becomes a disciplined and self-reflexive practice of using common sense, where we anticipate in transparent ways and then seek to assess the plausibility of the causal connections thus proposed by looking for empirical information that supports it.

5. In fairness, it should be noted that exploratory research cannot avoid the risk of personal bias. However, instead of pretending to conduct "objective" research able to unveil "universal" patterns, critical and self-reflective exploratory research seeks to lay bare the personal bias of the researcher up front, thus allowing the reader to consider it. Instead of unveiling universal laws, such research is also more limited in scope in that it can only reveal what is accessible to a given researcher at a given time, under the given circumstances and limitations. As such, it is more objective than the research produced by all those "playing the God trick" (Haraway 1988).

6. Understanding and explaining the ontological ramifications of dialectics exceeds not only the space available, but also my training as a political scientist.

\section{CHAPTER 2. CONCEPTUALIZING CITIZENSHIP: DISJUNCTIVE, DUAL, DIVIDED, ENTANGLED, OR WHAT?}

1. As argued, e.g., by Mireille Rosello 2001.

2. It seems important to explain that my own interest in citizenship does not take issue with a whole set of arguments about what rights are, and if social reality can be influenced by such lofty concepts as citizenship rights or social rights. I am skeptical about the potential of laws to produce reality, and aware of the pitfalls of legal idealism. Citizenship, here, shall thus not refer to a set of entitlements of citizens. This book is instead concerned with the quality and the conditionalities that restrict the political, civil, and social rights of certain individuals and groups within a citizenry. Stated more precisely, I want to analyze how societal dynamics affect and condition the quality of citizenship. T. H. Marshall's essay had a narrower interest, namely, to analyze the relationship between citizenship and capitalism. He was thus able to see that "The components of a civilized and cultured life, formerly the monopoly of the few, were brought progressively within reach of the many, who were encouraged thereby to stretch out their hands towards those that still eluded their grasp. The diminution of inequality strengthened the demand for its abolition, at least with regard to the essentials of social welfare" (T. H. Marshall 1992: 37). 
3. The tension between formal rights and actual practice merits a more detailed treatment, especially in Latin America, where legal idealism is the norm, which refers to the fact that legal codes do not necessarily reflect reality, but represent an ideal situation. The writing and codification of these legal codes has been an elite affair, which raises the question of how much Latin American elites really know, or want to know, about the realities of the majority in the countries they live in. Considering Latin America's colonial past, it is not a far shot to argue that Latin American elites have codified an idealized European reality that is entirely out of sync with the actual reality of the country in question. See Reiter 2009, chapter 8.

4. This logic hinges on the almost exclusive treatment of citizenship as a set of rights, thus stripped of its original content, which included obligations and responsibilities. The history of how citizenship developed from a political right to participate in the making of the rules by which one abides, to the notion of certain rights and goods that the state has to provide will be part of my forthcoming book. John Pocock (in Beiner 2007) has already focused on this shift from political to legal citizenship that occurred under the late Roman Republic.

5. It is worth noting here that this logic also seems to apply to those societies that have created myths of "Aryanism," e.g., India or Iran. In both countries, whiteness is highly valued and constantly negotiated, which means that individuals seek to achieve it by engaging in different strategies. These include biological elements, such as the very common skin-bleaching, as well as symbolic ones, manifested in behavioral codes, language, dress, and general habitus.

6. It also highlights the importance of black republicans, such as FrançoisDominique Toussaint L'Ouverture and Jean-Jacques Dessalines, who fought for liberté, égalité, and fraternité against the French army sent to the Caribbean to restore slavery.

\section{CHAPTER 3. CLASSICAL CITIZENSHIP: THE POLITICAL AND THE SOCIAL}

1. My focus on the classical democracies of Athens and Rome is not motivated by any claims that these democracies were the only ones that existed, or any related claims about the supremacy of the Western tradition over others.

2. There is considerable discussion about what these extra powers were. Rihil (1995) considers that "the Areopagus was rejecting significant numbers of magistrates at their dokimasiai and Ephialtes' reforms sought first and 
foremost to transfer this power to the candidate's peers" (Rihil 1995: 87). Sealey (1964) looks instead to the end of the term, arguing that Ephialtes's reforms were essentially concerned with the procedures for calling magistrates to account when they left office, making them vulnerable to accusations of corruption.

3. It is important to note the role played by nonstate entities in helping to determine citizenship qualifications. Lambert's (1993) work examines this aspect and he notes, "In practice the phratry played the major role in controlling the major qualification for citizenship, Athenian descent" (Lambert 1993: 49). This was even more the case prior to 508 B.C.E., when the phratries had included all the citizens; in other words, "Those whose names were lacking in the phratry rolls lacked ipso facto citizenship" (Ferguson 1910: 259). The ten new tribes created by Cleisthenes were intended to challenge these nonstate groups.

4. According to Plutarch (1960), Solon "permitted only those [xenoi] to be made citizens who were permanently exiled [from their home cities] or who removed to Athens with their entire family to ply a trade. This he did, as we are told, not so much to drive away other foreigners, as to invite these particular ones to Athens with the assurance of becoming citizens" (Life of Solon 24.2). This is consistent with Manville's ideas concerning the "usefulness" of the citizen body to the polis (Manville 1997: 32).

5. Ostwald (1996) further clarifies that "All citizens are equally 'privileged': the privilege is a privilege only to the extent that slaves and foreigners are excluded" (Ostwald 1996: 54f).

6. Aristocratic cultic associations did not die out, however, but instead took on new roles and remained integral to Athenian religious and social life for a considerable period of time (Lambert 1993).

\section{CHAPTER 4. MEDIEVAL EUROPEAN CITIZENSHIP: CHRISTIAN RIGHTS AND JEWISH DUTIES}

1. In 1993, the University of Copenhagen-based Copenhagen Polis Centre, under Mogens Herman Hansen, initiated a broad research program called Poleis and City-States, 600-323 B.C.E., which is steadily producing more evidence on the history of city-states around the world. The findings already produced by this center testify against the assumption that city-states, democratic and nondemocratic ones, only emerged in the Western world. 


\section{CHAPTER 5. FRANCE: LIBERALISM UNVEILED}

1. Quoted from John Thornhill, the Financial Times, November 8, 2005.

2. E.g., by Etienne Balibar (2004).

3. TNS SOFRES 2007 survey results available online at http://lecran.org/?p=243.

4. Interview conducted on June 20, 2011.

5. Interview conducted on June 20, 2011, Rouen.

6. As Frenchman Alexis de Tocqueville had diagnosed already in the 1830s, when writing about the structural contradictions inherent in democracies, in Democracy in America.

\section{CHAPTER 6. THE POSTCOLONIAL WITHIN: PORTUGAL, WHITE AND EUROPEAN}

1. A search in what is probably the most prestigious academic social-science journal published in Portugal, Análise Social, revealed that between 2000 and 2009 this journal published twenty articles focusing on migration, but only one that focuses on ethnic minorities_-published in 2005 by Fernando Luís Machado, Ana Raquel Matias, and Sofia Leal, who analyze the effects of cultural differences on school performance (Análise Social 40, no. 3 (2005): 695-714. Notable exceptions to this tendency to render minorities invisible practiced by Portuguese academia include the work of Teresa Fradique, Antonio Contador, Margarida Marques, and Maria Joao Valente Rosa.

2. http://alfa.fct.mctes.pt/estatisticas/global.

3. A fact highlighted by Marques et al. 2007.

4. Interview conducted on June 10, 2003, in Lisbon, my translation. The complete quote was printed in Reiter 2009: 409.

5. ARTIGO $1^{\circ}$ (Nacionalidade originária). 1-São Portugueses de origem: Os filhos de pai português ou mãe portuguesa nascidos em território português ou sob administração portuguesa, ou no estrangeiro se o progenitor português aí se encontrar ao serviço do Estado Português; b) Os filhos de pai português ou mãe portuguesa nascidos no estrangeiro se declararem que querem ser portugueses ou inscreverem o nascimento no registo civil português; c) Os indivíduos nascidos em território português filhos de estrangeiros que aqui residam habitualmente há, pelo menos, seis anos não estejam ao serviço do respectivo Estado, se declararem que querem ser portugueses; d) Os indivíduos nascidos em território português quando não possuam outra nacionalidade. 2-Presumem-se nascidos em território português ou sob 
administração portuguesa, salvo prova em contrário, os recém-nascidos expostos naqueles territórios.

A new law, passed in July 2007, amends the constitution to the extent that legal residence of foreigners is regulated through the introduction of a legal residence card. This new law does not change the definition of citizenship by descent.

6. Interview conducted on December 6, 2003.

7. Banco de Portugal, "Remittances in the Portuguese Balance of Payments," Luxembourg Group on Remittances, June 26-27, 2006, available online: http://www.imf.org/external/np/sta/bop/2006/luxgrp/pdf/italy.pdf.

8. MPI: http://www.migrationinformation.org/feature/display.cfm?ID=77.

9. Jornal Publico, January 21, 2009, 11-12.

\section{CHAPTER 7. BRAZIL: EXPERTS IN EXCLUSION}

1. Interview conducted in São Luis, June 30, 2008.

2. By presenting these examples, Reis also sheds light on the often-discussed phenomenon of clientelism. She explains: "Those who, for example, ask desperately for a job have already searched the job market in vain and they do not see another alternative but to implore for an intervention of the authorities so that they can exercise their right to make a living through work" (Reis 1990: 166).

3. Defined as fifteen years and older with less than four years of schooling.

4. IBGE, 2008.

5. World Bank Confidential Report No. 40011-BR: Brazil: Knowledge and Innovation for Competitiveness, available online at: http://www.planejamento.gov .br/secretarias/upload/Arquivos/seain/Conhecimento_Inovacao_Competiti vidade.pdf.

6. With apologies to my friend, Federal Judge João Batista de Castro Junior, in the original: "Para penetrar as esferas de poder, cidadãos brasileiros têm que imitar o 'habitus' dos poderosos. Recentemente, iniciou-se no Brasil um movimento liderado pela associação dos magistrados brasileiros (АМB) para convencer seus associados da necessidade de mudança na linguagem. Nossas observaçóes preliminares, como participantes deste esforço, levam-nos a um diagnóstico pessimista dessa iniciativa por constatar que as discussóes a este respeito já começaram desfocadas, o que mostra o grau de alheamento desses ensaios endógenos de problematização bacharelesca, pois confunde linguagem com perfil estilístico, esquecendo-se da advertência buffoniana de que 'le style 
est l'homme même,' além de ir contra a especialização terminológica—do que decorrem os chamados tecnoletos-que todo saber técnico-científico deve ter. $\mathrm{Na}$ verdade, a questão tem uma profundidade não apreensível com essa superficialidade: ao longo de sua evolução histórica, a linguagem do bacharelismo jurídico permaneceu ensimesmada tanto quanto o conhecimento que ela veicula, negligenciando que 'la liberdad del lenguaje es libertad histórica, libertad del hombre como ser histórico.' Sem voltar-se para a própria realidade social a que teoricamente deveria dirigir-se, esse instrumental linguageiro, embora atualmente menos pervadido de afetaçóes literárias de gosto duvidoso, permaneceu com ar de esquizoidia social ainda que o beletrismo tenha perdido substância na formação atual dos bacharéis."

7. In the original: "Ministério da Justiça, conselho nacional dos direitos da criança e do adolescente, ata da septuagésima sétima assembléia ordinária realizada em 14 de fevereiro de 2001: Às nove horas e quarenta minutos do dia quatorze de fevereiro de dois mil e um, deu-se início a Septuagésima Sétima Assembléia Ordinária do Conselho Nacional dos Direitos da Criança e Do Adolescente (ConAnda), presidida pelo seu Presidente Cláudio Augusto Vieira da Silva (fundação fe e alegria do brasil). Presentes os Conselheiros titulares Maria Izabel da Silva (CUT); Kênia Augusta Figueiredo (CFEss); José Fernando da Silva (centro de-cultura luiz freire); Rachel Niskier Sanchez (SBP); Valéria Getúlio de Brito (MNDH); Ozantra Ferreira Costa (CECRIA); Guilbert Ernesto de Freitas Nobre (Ms); Olga Câmara (MJ) (parcialmente); Caio Luiz Davoli Brandão (MP); Euridice Nóbrega Vidigal (MF) (parcialmente). Presentes também, os conselheiros-governamentais suplentes que assumiram a titularidade nesta assembléia; Júlio Boaventura Santos Matos (MrE); Marilda Marfan (MEC); Eliana Cristina Crisóstomo (MJ) (parcialmente); Ivone Bezerra-de Mello (MTE); Clóvis Ubirajara Lacorte (Casa Civil), Registramos a ausência justificada dos conselheiros do mpas e da Casa Civil. Por motivo de ausência justificada dos conselheiros titulares_da CNBB e da PUC/sP, foram convocados e estiveram presentes os conselheiros não-governamentais que assumiram a titularidade nesta assembléia: Olympio de Sá Sotto Maior (ABMP) e Marcos Antonio Paiva-Colares (OAB). Presentes também os conselheiros suplentes da sociedade civil Silvio Alberto Valente Soares (ABrapia) e Laura Rosseti (FENASP). Por motive de ausência do conselheiro da Normando Batista Santos da ABONG, o conselheiro Silvio Valente da ABrapia assumiu a titulariedade no segundo dia da asembléia. O Presidente abriu os trabalhos dando as boas vindas a todos, pela participação da primeira assembléia do novo milênio e em seguida submeteu á pauta à plenária, tendo a mesma sido aprovada com alteração do item oitavo do segundo dia, transferindo-o para o iten quarto do primeiro dia. No item Assuntos gerais, foram solicitados o 
agendamento das assembléias do exercício; discussão sobre a Acão Direta de Inconstitucionalidade dos artigos duzentos e cinqüenta e quatro e duzentos e cinqüenta e cinco do Estatuto da Criança e do Adolescente, proposta pelo Partido Trabalhista Brasileiro—PTB—e participação do ConANDA no Comitê de Acompanhamento das Políticas Sociais de Ségurança Pública. Os demais itens permaneceram inalterados. Prosseguindo, o Presidente propôs alteraçóes na composição das Comissóes Temáticos e Grupos de Trabalhos existentes, justificando que a referida alteração nao fere o Regimento Interno do Conselho. Informou que as Comissoes aglutinarao os eixos tematicos, passando a funcionar como segue: 1) Comissão de Articulação—-terá como eixo temático os Conselhos Estaduais, Municipais das Capitais e Conselhos Tutelares; 2) Comissão de Orçamento e Finanças — tera como eixo temático as medidas, sócio educativas; 3) Comissão de Políticas Públicas-terá como éixo temático a Quarta Conferência Nacional; 4) Comissão de Comunicação—as açóes desta Comissão serão desenvolvidas em parceria_ — com a ANDI ficando restrita aos encaminhamentos necessários para em conjunto coma a ANDI desenvolver a política de Comunicaçáo: A proposta foi debatida e aprovada por todos. Em seguida, passou-se a composição dos seus integrantes ficando assim constituída: . . . As Comissōes Temáticas se reuniram no período da manhã e início da tarde para tratarem de assuntos especificos de suas áreas de atuação, atualização das pendências das assembléias anteriores e elaboração do plano de ação e de metas para o exercício de dois e um.”

8. The appeal of Sarah Palin in the United States, and also the election of Barack Obama to the presidency can be explained to a great extent by this framework - that is, their appeal to groups of citizens who feel underrepresented or not represented, be it youth, in the case of Obama, or patriotic right-wingers, in the case of Palin.

\section{CHAPTER 8. COLOMBIA: WHEN LAW AND REALITY CLASH}

1. The state, however, did not provide the same right to other Afro-Colombian "ancestral" communities living outside of the Pacific coastal areas.

2. It was integrated into national legislation by Law 21 of 1991 (Ley 70 de 1993-Decreto 2248 de 1995).

3. New York, March 7, 1966, ratified in 2004.

4. Long Term Plan for the Black Population, Afro-Colombians, Palenque y Raizal: Proposal y Process 2005-2007, National Department of Planning, 2007. 
5. I am aware that this is a very general statement, and that Law 70 has been used to challenge the constitutionality of development projects, land invasions, and even state actions-for example, in the notorious Curvaradó and Jiguamiandó cases of October 2009 (Giupponi 2010). However, the number of lawsuits brought forward by the Colombian populations against abuse and violation by the government or private entities is still extremely low if compared to most rich countries. The general inefficiency of the law in upholding and defending the interests of the general population was confirmed by the Colombian ombudsman for the Chocó department (Defensor del Pueblo) in an interview conducted on March 18, 2011, in Quibdó. The fact that those who actually seek to use the law for human-rights purposes are routinely threatened and killed gives further evidence of the general weakness of Colombian law as a mechanism to uphold justice.

6. Even though Law 70 has politicized a whole new group of people, who before were at the margin both economically and politically, see Oslender 2004.

\section{CHAPTER 9. CONCLUSION: LEARNING FROM EXPLORATORY RESEARCH}

1. This is a case where concrete historical changes impact the way reality has to be analyzed - in other words, where ontology impacts epistemology. As such, it points at the interdependence of ontology and epistemology to the extent that empirical changes, such as the changing character of citizenship, trigger the application of an analytical framework such as market theory. 


\section{References}

Abad I Ninet, Antoni, and Josep Monserrat Molas. December 2009. "Habermas and Ackerman: A Synthesis Applied to the Legitimation and Codification of Legal Norms." Ratio Juris 22, no. 4: 510-31.

Adcock, Frank E. 1969. Roman Political Ideas and Practice. Ann Arbor: University of Michigan Press.

Adorno, Theodor W. 1973. Negative Dialectics. New York: Seabury Press.

Afro-Colombian National Movement Cimarrón. 2004. Report on the Human Rights Situation of Afro-Colombians (1994-2004). Bogota: Movimiento Nacional Cimarrón.

Agamben, Giorgio. 1998. Homo Sacer. Stanford, CA: Stanford University Press.

Agudelo, Carlos. 2002. "Etnicidad negra y elecciones en Colombia." Journal of Latin American Anthropology 7, no. 2: 168-97.

. 2004. "La Constitución Política de 1991 y la inclusión ambigua de las poblaciones negras." Utopia para los excluidos: El multiculturalismo en Africa y América Latina. Bogota: Universidad Nacional de Colombia.

Agüero, Felipe, and Jeffrey Stark, eds. 1998. Fault Lines of Democracy in PostTransition Latin America. Miami: North South Center Press.

Aleinikoff, Alexander, and Douglas Klusmeyer. 2002. Citizenship Policies for an Age of Migration. Washington DC: Carnegie Endowment for International Peace; Migration Policy Institute.

Alkire, Sabina. 2005. Valuing Freedoms: Sen's Capability Approach and Poverty Reduction. New York: Oxford University Press.

Almond, Gabriel, and Sidney Verba. 1963. Civic Culture. New York: Sage Publications. Alvesson, Mats, and Kaj Skoldberg. 2009. Reflexive Methodology. New York: Sage Publications.

Anand, Sudhir, and Amartya K. Sen. 1994. "Human Development Index: Methodology and Measurement." Human Development Index: Methodology and Measurement. New York: United Nations Development Programme.

Anderson, Benedict. 2006. Imagined Communities. New York: Verso.

Andrews, George Reid. 2004. Afro-Latin America, 1800-2000. New York: Oxford University Press. 
Arce, Moisés, and Leonardo Reales. 2006. "Violencia política, asistencia militar de USA y producción de coca en los Andes Centrales." Revista de Ciencia Política Universidad Católica de Chile 26, no.1: 25-47.

Arendt, Hannah. 1966. The Origins of Totalitarianism. New York: Harcourt.

Aristotle. 1992. Politics. New York: Cambridge University Press.

Arocha, Jaime. 1998. "Inclusion of Afro-Colombians: Unreachable National Goal?" Latin American Perspectives 25, no. 3: 70-89.

- 2004. Utopia para los excluidos. El multiculturalismo en África y América Latina. Bogota: Universidad Nacional de Colombia.

Asher, Kiran. 2009. Black and Green: Afro-Colombians, Development, and Nature in the Pacific Lowlands. Durham, NC: Duke University Press.

Association of Displaced Afro-Colombians and Global Rights. 2009. Life in the Face of Adversity: The Human Rights Situation of Internally Displaced Afro-Colombian Women. Washington, D.C.: Global Rights.

Avritzer, Leonardo. 2009. Participatory Institutions in Democratic Brazil. Baltimore: Johns Hopkins University Press.

Bachrach, Bernard. 1977. Early Medieval Jewish Policy in Western Europe. Minneapolis: University of Minnesota Press.

Balibar, Etienne. 2004. We, the People of Europe? Princeton, NJ: Princeton University Press.

Balibar, Etienne, and Immanuel Wallerstein. 1991. Race, Nation, Class. New York: Verso.

Barbary, Olivier, and Fernando Urrea. 2004. Gente Negra en Colombia: Dinámicas Sociopoliticas en Cali y el Pacifico. Cali, Colombia: Cidse-Ird-Colciencias.

Barbary, Olivier, Héctor Fabio Ramírez, and Fernando Urrea. 2003. Identidad y ciudadanía Afrocolombiana en la región Pacífica y Cali: Elementos estadísticos y sociológicos para el debate de la 'cuestión negra' en Colombia. Estudos AfroAsiáticos 25, no. 1: 75-121.

Baubock, Rainer, and John Rundell, eds. 1998. Blurred Boundaries: Migration, Ethnicity and Citizenship. Aldershot, UK: Ashgate.

Bauman, Zygmunt. 2001. Modernity and the Holocaust. Ithaca, NY: Cornell University Press.

Bayart, Jean-François. 1996. Lillusion identitaire. Paris: Librairie Arthème Fayard.

Beiner, Ronald. 1995. Theorizing Citizenship. Albany, NY: SUNY Press.

Bello, Álvaro, and Marta Rangel. 2002. "La equidad y la exclusión de los pueblos indígenas y Afrodescendientes en América Latina y el Caribe." Revista de la CEPAL 76: 39-54.

Bendix, Reinhard. 1969. Nation-Building and Citizenship. New York: Anchor Books. Berger, Peter, and Thomas Luckmann. 1966. The Social Construction of Reality. New York: Doubleday. 
Bernal, Martin. 1987. Black Athena: The Afroasiatic Roots of Classical Civilization. New Brunswick, NJ: Rutgers University Press.

Bernard, Philippe. 2004. La Crème des Beurs. Paris: Seuil.

Bernasconi, Robert, and Tommy Lee Lott, eds. 2000. The Idea of Race. Indianapolis: Hackett Publishing Co.

Bethencourt, Francisco, and Kirti Chaudhuri, eds. 2000. História da Expansão Portuguêsa. Vol. 4: 521-50. Navarra: Temas e Debates.

Bhaskar, Roy. 2008. A Realist Theory of Science. New York: Verso.

Blackburn, Robin. 1988. The Overthrow of Colonial Slavery, 1776-1848. New York: Verso.

Blanshei, Sarah Rubin. 1976. "Perugia, 1260-1340: Conflict and Change in a Medieval Italian Urban Society." Transactions of the American Philosophical Society, New Series 66, no. 2 (1976): 1-128.

Boatcă, Manuela. 2010. “Class vs. Other as Analytical Categories.” In Mass Migration in the World-System: Past-Present, and Future, ed. Terry-Ann Jones and Eric Mielands, 38-54. Boulder: Paradigm Publishers.

Bonilla-Silva, Eduardo. 2009. Racism without Racists. New York: Rowman and Littlefield.

Bossy, John. 1998. Peace in the Post-Reformation. Cambridge: Cambridge University Press.

Botsford, George Willis. 1968. The Roman Assemblies. New York: Cooper Square Publishers.

Bottomore, Tom. 1992. "Forty Years On." In Citizenship and Social Class, by T. H. Marshall, 55-93. London: Pluto Press.

Bourdieu, Pierre. 1987. Distinction: A Social Critique of the Judgment of Taste. Cambridge, MA: Harvard University Press.

- 2003. Language and Symbolic Power. Cambridge, MA: Harvard University Press.

Bowen, William, and Derek Bok. 2000. The Shape of the River. Princeton, NJ: Princeton University Press.

Brady, Henry, and David Collier, eds. 2004. Rethinking Social Inquiry. Lanham, MD: Rowman and Littlefield.

Brown, Michael, et al., eds. 2003. Whitewashing Race: The Myth of a Color-Blind Society. Berkeley: University of California Press.

Brubaker, Rogers. 1989. Immigration and the Politics of Citizenship in Europe and North America. Lanham, MD: University Press of America.

. 1992. Citizenship and Nationhood in France and Germany. Cambridge, MA: Harvard University Press.

Press. 
Brunt, Peter A. 1971. Social Conflicts in the Roman Republic. New York: W.W. Norton. Bryant, Anthony, and Kathy Charmaz, eds. 2010. The Sage Handbook of Grounded Theory. Beverly Hills, CA: Sage Publications.

Butler, Judith. 1998. "Merely Cultural.” New Left Review 227 (January/February 1998): 33-43.

Cairo, Heriberto. 2006. “'Portugal Is Not a Small Country': Maps and Propaganda in the Salazar Regime.” Geopolitics 11 (2006): 367-95.

Capotorti, Francesco. 1991. Study on the Rights of Persons Belonging to Ethnic, Religious and Linguistic Minorities. New York: United Nations.

Carey, C. 1995. "Rape and Adultery in Athenian Law." The Classical Journal, New Series 45, no. 2 (1995): 407-17.

Castillo, Luis Carlos. 2007. Etnicidad y Nación. El desafío de la diversidad en Colombia. Cali, Colombia: Universidad del Valle.

Castoriadis, Cornelius. 1985. "First Institution of Society and Second-Order Institutions." In Figures of the Unthinkable. http://www.notbored.org/FTPK.pdf.

- 1990. "What Democracy?" In Figures of the Unthinkable. http://www.notbored.org/FTPK.pdf.

- 1991. "Aeschylean Anthropogony and Sophoclean Self-Creation of Man." In Figures of the Unthinkable. http://www.notbored.org/FTPK.pdf.

- 2001. "The Retreat from Autonomy: Post-modernism as Generalised Conformism.” Democracy \& Nature 7, no. 1: 17-26.

Castro Júnior, João Batista de, and Bernd Reiter. 2007. "Continuidade e Mudança no Brasil: Os Legados do Bacharelismo," Revista de Direito Federal 88: 81-101.

Chakrabarty, Dipesh. 2000. Provincializing Europe. Princeton, NJ: Princeton University Press.

Chapman, Herrick, and Laura Frader, eds. 2004. Race in France. New York: Berghahn Books.

Chazan, Robert. 2006. The Jews of Medieval Western Christendom, 1000-1500. New York: Cambridge University Press.

Cohen, Edward E. 2000. The Athenian Nation. Princeton, NJ: Princeton University Press.

Cohen, Robert, and Marx Wartofsky, eds. 1983. Epistemology, Methodology, and the Social Sciences. Boston: D. Reidel Publishing Company.

Condon, Stephanie, and Philip Ogden. 1991. "Afro-Caribbean Migrants in France: Employment, State Policy and the Migration Process." Transactions of the Institute of British Geographers 16, no 4: 440-57.

CONPES. 2004. 3310 de 2004-Politica de Acción Afirmativa para la Población Negra o Afrocolombiana. DNP.

Constant, Fred. 2009. "Talking Race in Color-Blind France: Equality Denied, 'Blackness' Reclaimed." In Black Europe and the African Diaspora, ed. Darlene 
Clark Hine, Trica Danielle Keaton, and Stephen Small, 145-60. UrbanaChampaign: University of Illinois Press.

Consultoria para los Derechos y el Desplazamiento (CODHES). 2008. "Afrocolombianos Desplazados: Un Drama sin Tregua." http://www.codhes.org/index .php?option=com_content\&task=view\&id $=157$.

Contador, Antonio. 2001. Cultura Juvenil Negra em Portugal. Oeiras: Celta.

Costa, Sérgio da. 2007. Vom Nordatlantik zum 'Black Atlantic.' Postkoloniale Konfigurationen und Paradoxien transnationaler Politik. Bielefeld, Germany: Transcript Verlag.

Crosby, Alfred. 1997. The Measure of Reality: Quantification and Western Society, 1250-1600. New York: Cambridge University Press.

Crul, Maurice, and Hans Vermeulen. 2003. "The Second Generation in Europe." International Migration Review 37, no. 4 (Winter 2003): 965-86.

Cunin, Elizabeth. 2003. "La política étnica entre alteridad y estereotipo. Reflexiones sobre las elecciones de marzo de 2002 en Colombia." Análisis Político 48: 77-93.

Dantas, Beatriz G. 1988. Vovó nagô e papai branco: Usos e abusos da África no Brasil. Rio de Janeiro: Graal.

Davidson, David. 1974. "On the Very Idea of a Conceptual Scheme." Proceedings and Addresses of the American Philosophical Association 47 (1973-74): 5-20.

Davies, John. 2004. "Athenian Citizenship: The Descent Group and the Alternatives." In Athenian Democracy, ed. P. J. Rhodes, 18-39. New York: Oxford University Press.

Departamento Administrativo Nacional de Estadística (DANE). 2007. "Colombia: una nación multicultural, Su diversidad étnica." http://www.dane.gov.co/ censo/files/presentaciones/grupos_etnicos.pdf.

Departamento Nacional de Planeación. 1999. Plan Nacional de Desarrollo Afrocolombiano (1998-2002). Bogota: Departamento Nacional de Planeación.

Diène, Doudou. 2004. Informe sobre la Misión del Relator contra el Racismo a Colombia llevada a cabo en 2003. Geneva, Switzerland: Naciones Unidas.

Dubois, Laurent. 2004. A Colony of Citizens. Chapel Hill: University of North Carolina Press.

Duffy, Bella. [1892] 2011. The Tuscan Republics. New York: G.P. Putnam's Sons.

Dugas, John. 1993. "El desarrollo de la Asamblea Nacional Constituyente." In La Constitución Política de 1991: ¿Un pacto político viable? John Dugas, ed. Bogota, Colombia: Uniandes.

Dunn, Ross. 2005. The Adventures of Ibn Battuta. Berkeley: University of California Press.

Dussel, Enrique. 1993. "Eurocentrism and Modernity." Boundary 2, vol. 20, no. 3 : 65-76. 
Dworkin, Ronald. 1978. Taking Rights Seriously. Cambridge, MA: Harvard University Press.

Eaton, Martin. 2001. "Lusophone-African Insertion in Portugal's Dual Labour Market.” IJIS 14, no. 3: 157-67.

Echchaibi, Nabil. 2001. "We Are French Too: Radio, Music and the Articulation of Difference among Young North Africans in France." International Communication Gazette 63, no. 4: 295-310.

Elias, Norbert. 2000. The Civilizing Process. Hoboken, NJ: Wiley-Blackwell.

Ellis, John, and G. R. Stanton. 1968. "Factional Conflict and Solon's Reforms." Phoenix 22, no. 2 (Summer 1968): 95-110.

Escalante, Aquiles. 1964. El negro en Colombia. Bogota: Universidad Nacional de Colombia.

Escobar, Arturo. 2008. Territories of Difference. Durham, NC: Duke University Press.

- 2003. "Displacement, Development, and Modernity in the Colombian Pacific." International Social Science Journal 55, no. 175: 157-67.

Eze, Emmanuel Chukwudi, ed. 2008. Race and the Enlightenment: A Reader. Hoboken, NJ: Wiley-Blackwell.

Fanon, Frantz. 1967. Black Skin, White Masks: The Experiences of a Black Man in a White World. New York: Grove Press.

- 1970. Toward the African Revolution. London: Penguin Books.

Faoro, Raymundo. [1957] 2001. Os donos do poder. Rio de Janeiro: Editora Globo.

Ferguson, William Scott. 1910. "The Athenian Phratries.” Classical Philology 5, no. 3 (1910): 257-84.

Fernandes, Florestan. 2006. A revolução burguesa no Brasil. Rio de Janeiro: Globo Editoras.

Feyerabend, Paul. 2010. Against Method. New York: Verso.

Fikes, Kesha. 2009. Managing African Portugal. Durham, NC: Duke University Press.

Finlay, Robert. 1982. "The Foundation of the Ghetto: Venice, the Jews, and the War of the League of Cambrai." Proceedings of the American Philosophical Society 126, no. 2 (April 1982): 140-54.

Finley, Moses. 1962. “Athenian Demagogues.” Past and Present 21 (April 1962): 3-24.

Fischer, Brodwyn. 2008. A Poverty of Rights. Stanford, CA: Stanford University Press.

Fradique, Teresa. 2003. Fixar o movimento: Representaçôes da música rap em Portugal. Lisbon: Publicaçôes Dom Quixote.

Fraser, Nancy. 1998: "Heterosexism, Misrecognition and Capitalism: A Response to Judith Butler." New Left Review 228 (March/April 1998): 140-49. 
Freire, Andre. 2007. "Minority Representation in Portuguese Democracy." Portuguese Journal of Social Science 6, no. 3: 193-211.

Freire, Paulo. 1993. Pedagogy of the Oppressed. New York: Continuum.

Friedemann, Nina S. de. 1984. "Estudios de negros en la antropología colombiana." In Un siglo de investigación social: Antropología en Colombia, ed. J. Arocha and N. S. de Friedemann, 507-72. Bogota: Etno.

—. 1991. "La Ley 70 de las Comunidades Negras." América Negra 6: 181-235. . 1993. La saga del negro. Presencia africana en Colombia. Bogota, Colombia: Pontificia Universidad Javeriana.

Frost, Frank. 1969. Democracy and the Athenians. New York: John Wiley and Sons. Gadamer, Hans Georg. 1994. Truth and Method. London: Sheed and Ward.

Gafaiti, Hafid. 2003. "Nationalism, Colonialism, and Ethnic Discourse on the Construction of French Identity." In French Civilization and Its Discontents, ed. Tyler Stovall and Georges van den Abbeele, 189-212. Lanham, MD: Lexington Books.

Garfinkel, Harold. 1967. Studies in Ethnomethodology. Upper Saddle River, NJ: Prentice Hall.

Gaspar, Tania, and Margarida Matos-Gaspar. 2009. "Adolescent's Lifestyles, Ethnicity and Socioeconomic Status in Portugal.” Cognition, Brain, Behavior 13 (2009): 49-57.

Gellner, Ernest. 1968. Words and Things. New York: Penguin Books.

George, Alexander, and Andrew Bennett. 2005. Case Studies and Theory Development. Cambridge, MA: MIT Press.

Gerring, John. 2001. Social Science Methodology. New York: Cambridge University Press.

- 2007. Case Study Research: Principles and Practices. New York: Cambridge University Press.

Giddens, Anthony. 1986. The Constitution of Society: Outline of the Theory of Structuration. Berkeley: University of California Press.

Giry, Stephanie. 2006. "France and Its Muslims." Foreign Affairs 85, no. 5 (September/October 2006): 87-104.

Giupponi, M. Belén Olmos. 2010. "La protección de las comunidades afrodescendientes en el sistema interamericano: Reflexiones a la luz del caso de las comunidades de Jiguamiandó y de Curbaradó.” Revista Electronica Iberoamericana 2, no. 4 (2010): 61-97.

Glick, Leonard. 1999. Abraham's Heirs: Jews and Christians in Medieval Europe. Syracuse, NY: Syracuse University Press.

Gnerre, Maurizzio. 1991. Linguagem, escrita e poder. Sao Paulo: Martins.

Goldstein, Leon. 1983. "Toward a Logic of Historical Constitution.” In Epistemology, Methodology, and the Social Sciences, eds. Robert Cohen and Marx Wartofsky, 19-52. Boston: Boston University. 
González, Felipe. 2004. Informe: Sistema judicial y racismo contra afrodescendientes. Santiago de Chile: CEJA.

Gordon, Edmund T. 1998. Disparate Diasporas: Identity and Politics in an AfricanNicaraguan Community. Austin: University of Texas Press.

Gordon, Paul. 1982. Fortress Europe? The Meaning of 1992. London: Runnymede Trust.

Gouschin, Valerij. 1999. "Pisistratus' Leadership in Athenaion Politeia 13.4 and the Establishment of the Tyranny of 561/560 B.C." The Classical Quarterly 49, no. 1 (1999): 14-23.

Gramsci, Antonio. 1999. Prison Notebooks. New York: Columbia University Press. Grueso Castelblanco, Libia Rosario. 2007. Documento Propuesta para la Formulación del Plan Integral de Largo Plazo Población NegralAfrocolombiana, Palenquera y Raizal 2007-2019. Bogota, Colombia: DNP.

2000. "El proceso organizativo de comunidades negras en el pacífico surcolombiano.” Master's thesis, Pontificia Universidad Javeriana, Colombia.

Grueso Castelblanco, Libia Rosario, Arturo Escobar, and Carlos Rosero. 1998. "The Process of Black Community Organization in the Southern Pacific Coast Region of Colombia." In Cultures of Politics, Politics of Culture: Re-Visioning Latin American Social Movements, eds. Arturo Escobar and Sonia Alvarez. Boulder, CO: Westview Press.

Habermas, Jürgen. 1985. The Theory of Communicative Action. Vol. 2, Lifeworld and System: A Critique of Functionalist Reason. New York: Beacon Press.

- 1988. On the Logic of Social Sciences. Cambridge, MA: MIT Press. 1998. Between Facts and Norms. Cambridge, MA: MIT Press.

Hall, Stuart. 1979. "Culture, the Media, and the Ideological Effect." In Mass Communication and Society, ed. James Curran et al. Beverly Hills, CA: Sage Publications.

Hansen, Mogens Herman. 1991. The Athenian Democracy in the Age of Demosthenes. Oxford: Blackwell Press.

ed. 1993. The Ancient Greek City-State. Acts of the Copenhagen Polis Centre 1. Det Kongelige Danske Videnskabernes Selskab. Copenhagen: Historiskfilosofiske Meddelelser, 72.

ed. 1996. Introduction to an Inventory of Poleis. Acts of the Copenhagen Polis Centre 3. Det Kongelige Danske Videnskabernes Selskab. Copenhagen: Historisk-filosofiske Meddelelser, 74.

Haraway, Donna. 1988. "Situated Knowledges: The Science Question in Feminism and the Privilege of Partial Perspective.” Feminist Studies 14, no. 3 (Autumn 1988): 575-99.

Harding, Sandra. 1991. Whose Science? Whose Knowledge? Ithaca, NY: Cornell University Press. 
Hark, Michel ter. 2003. "Searching for the Searchlight Theory: From Karl Popper to Otto Selz." Journal of the History of Ideas 64, no. 3 (July 2003): 465-87.

- 2004. Popper, Otto Selz, and the Rise of Evolutionary Epistemology. Cambridge: Cambridge University Press.

Harris, Cheryl. 1993. "Whiteness as Property." Harvard Law Review 106: 276-91. Harris, Edward M. 2002. "Edward E. Cohen, 'The Athenian Nation.'” American Historical Review 107, no. 3 (June 2002): 919-20.

Hegel, Georg Wilhem Friedrich. 1979. Phenomenology of Spirit. New York: Oxford University Press.

Hempel, Carl. 1966. Philosophy of Natural Science. New Jersey: Prentice Hall.

Hillel, Soifer, and Matthias vom Hau. 2008. "Unpacking the Strength of the State: The Utility of State Infrastructural Power." Studies in Comparative International Development 43, no. 3-4 (2008): 219-30.

Hine, Darlene Clark, Trica Danielle Keaton, and Stephen Small, eds. 2009. Black Europe and the African Diaspora. Urbana-Champaign: University of Illinois Press.

Hirsch, Fred. 1976. Social Limits to Growth. Cambridge, MA: Harvard University Press.

Hobsbawm, Eric. 2003. Nations and Nationalism since 1780. New York: Cambridge University Press.

Hoffmann, Odile. 2002. "Collective Memory and Ethnic Identities in the Colombian Pacific." Journal of Latin American Anthropology 7, no. 2: 118-39.

Hogan, Dennis. P., and David L. Featherman. 1977. Racial stratification and socioeconomic change in the American North and South. American Journal of Sociology 83, no. 1: 100-26.

Holston, James. 2008. Insurgent Citizenship. Princeton, NJ: Princeton University Press.

Holston, James, and Arjun Appadurai. 1996. "Cities and Citizenship.” Public Culture 8 (1996): 187-204.

Holston, James, and Teresa Caldeira. 1998. "Democracy, Law, and Violence: Disjunctions of Brazilian Citizenship." In Fault Lines of Democracy in PostTransition Latin America, eds. Felipe Agüero and Jeffrey Stark, 263-96. Miami: North-South Center Press.

Holt, Thomas C. 1992. The Problem of Freedom. Baltimore: Johns Hopkins University Press.

Hooker, Juliet. 2005. "Indigenous Inclusion/Black Exclusion: Race, Ethnicity and Multicultural Citizenship in Latin America." Journal of Latin American Studies 37, no. 2 (May): 285-310.

Hopenhayn, Martín. 2001. Discriminación étnico-racial y xenofobia en América Latina y el Caribe. Santiago de Chile: ECLAC. 
Horkheimer, Max, and Theodor W. Adorno. [1944] 1997. Dialectic of Enlightenment. London: Verso.

Hortas, Maria João. 2008. "Territories of Integration: The Children of Immigrants in the Schools of the Metropolitan Area of Lisbon." Intercultural Education 19, no. 5 (October 2008): 421-33.

Instituto Brasileiro de Geografia e Estatística. 2010. "2010 Municipal Social Indicators: Incidence of Poverty Is Higher in Medium Size Municipalities." http://www.ibge.gov.br/english/presidencia/noticias/noticia_visualiza.php?id _noticia=2019\&id_pagina $=1$.

Inter-American Dialogue. 2004. Race Report: Constitutional Provisions and Legal Actions Related to Discrimination and Afro-Descendant Populations in Latin America. Washington, D.C.: Inter-American Dialogue.

Isin, Engin. 2000. Democracy, Citizenship, and the Global City. New York: Routledge. - 2008. Recasting the Social in Citizenship. Toronto: University of Toronto Press.

Jaher, Frederic Cople. 2002. The Jews and the Nation. Princeton, NJ: Princeton University Press.

James, C.L.R. 1938. The Black Jacobins. London: Secker and Warburg.

John, Edson de Oliveira Nunes, and Thomas E. Bogenschild, eds. 1987. State and Society in Brazil: Continuity and Change, 307-35. Boulder, CO: Westview Press.

Jones, Emma, and John Gaventa. 2002. Concepts of Citizenship: A Review. Sussex, UK: IDS Publications.

Jones, Nicholas. 1999. The Associations of Classical Athens. New York: Oxford University Press.

Keaton, Trica Danielle. 2009. “'Black (American) Paris' and the French OuterCities: The Race Question and Questioning Solidarity." In Black Europe and the African Diaspora, ed. Darlene Clark Hine, Trica Danielle Keaton, and Stephen Small, 95-118. Urbana-Champaign: University of Illinois Press.

Kim, Keechang. 2004. Aliens in Medieval Law. Cambridge: Cambridge University Press.

Kirkendall, Andrew. 2002. Classmates: Male Student Culture and the Making of a Political Class in Nineteenth-Century Brazil. Omaha: University of Nebraska Press.

Kiwan, Nadia. 2007. "Equal Opportunities and Republican Revival: Post-Migrant Politics in Contemporary France." International Journal of Francophone Studies 10, nos. 1-2: 157-72.

Knight, Franklin W. 1990. The Caribbean: The Genesis of a Fragmented Nationalism. New York: Oxford University Press.

Kohli, Atul. 2004. State-Directed Development. New York: Cambridge University Press. 
Kriesi, Hanspeter. 2008. Direct Democratic Choice: The Swiss Experience. Lanham: Lexington.

Kuhn, Thomas. 1996. The Structure of Scientific Revolutions. Chicago: University of Chicago Press.

Kymlicka, Will. 2007. Multicultural Odysseys: Navigating the New International Politics of Diversity. New York: Oxford University Press.

Laachir, Karima. 2007. "France's 'Ethnic' Minorities and the Question of Exclusion.” Mediterranean Politics 12, no. 1 (March 2007): 99-105.

Lakoff, George. 2009. The Political Mind. New York: Penguin.

Lambert, Stephen. 1993. The Phratries of Athens. Ann Arbor: University of Michigan Press.

Lander, Edgardo. 2002. "Eurocentrism, Modern Knowledges, and the 'Natural' Order of Global Capital." Nepantla 3, no. 2 (2002): 245-68.

Lasso, Marixa. 2007. Myths of harmony. Race and Republicanism during the Age of Revolution, Colombia,1795-1831. Pittsburgh, PA: University of Pittsburgh Press.

Latour, Bruno, Steve Woolgar, and Jonas Salk. 1986. Laboratory Life. Princeton, NJ: Princeton University Press.

Lefebvre, Edwige Liliane. 2003. "Republicanism and Universalism: Factors of Inclusion and Exclusion in the French Concept of Citizenship." Citizenship Studies 7, no. 1 (2003): 15-36.

Lennox, Corinne. 2006. The Changing International Protection Regimes for Minorities and Indigenous Peoples: Experiences from Latin America and Africa. London: London School of Economics and Political Science.

Leonard, Yves. 2000. "A idea colonial: Olhares cruzados." In História da Expansão Portuguêsa, ed. Francisco Bethencourt and Kirti Chaudhuri, 4:521-50. Navarra: Temas e Debates.

Lesser, Jeffrey. 1999. Negotiating National Identity. Durham, NC: Duke University Press.

Lieberman, Robert. 2005. Shaping Race Policy. Princeton, NJ: Princeton University Press.

Little, Daniel. 1998. Microfoundations, Methods, and Causation. New Brunswick, NJ: Transaction Publishers.

Livy. 2002. The Early History of Rome. London: Penguin Classics.

Lozès, Patrick. 2007. Nous, les Noirs de France. Paris: Éditions Danger Public.

. 2009. Les Noirs sont-ils des Français à part entière? Paris: Éditions Larousse.

Luhmann, Niklas. 1996. Social Systems. Stanford, CA: Stanford University Press.

Luxembourg Group of Remittances. 2006. Remittances in the Portuguese Balance of Payments. Lisbon: Banco de Portugal, available online: www.imf.org/external/ np/sta/bop/2006/luxgrp/pdf/portug.pdf. 
Lynch, Dennis O. 1981. Legal Roles in Colombia: Studies of Law in Social Change and Development. Uppsala and New York: Scandinavian Institute of African Studies and International Center for Law in Development.

Machado, Fernando Luis, Ana Raquel Matias, and Sofia Leal. 2005. "Desigualdades sociais e diferencas culturais: Os resultados escolares dos filhos de imigrantes africanos." Análise Social 40, no. 3 (2005) (No. 176): 695-714.

Mackenney, Richard. 1989. The City State, 1500-1700. Atlantic Highlands, NJ: Humanities Press International.

Mahoney, James, and Dietrich Rueschemeyer. 2003. Comparative Historical Analysis in the Social Sciences. New York: Cambridge University Press.

Mander, John. 1969. The Unrevolutionary Society. New York: Knopf.

Mansbridge, Jane. 1980. Beyond Adversary Democracy. New York: Basic Books.

Manville, Philip Brook. 1997. The Origins of Citizenship in Ancient Athens. Princeton, NJ: Princeton University Press.

Marcuse, Herbert. 1955. Reason and Revolution. New York: Humanities Press. 1960. Reason and Revolution. Boston: Beacon Press.

Marques, Margarida, Maria Joao Valente Rosa, and Joana Lopes Martins. 2007. "School and Diversity in a Weak State: The Portuguese Case." Journal of Ethnic and Migration Studies 33, no. 7 (September 2007): 1145-68.

Martínez Cobo, José. 1986. Study of the Problem of Discrimination against Indigenous Populations. New York: United Nations.

Marshall, T. H. [1950] 1992. Citizenship and Social Class. London: Pluto Press.

Marx, Karl. [1841-42] 1971. "Kritik der Hegelschen Staatsphilosophie." In Die Fruehschriften, 20-149. Stuttgart: Alfred Kroener Verlag.

Marx, Karl, and Friedrich Engels. [1848] 1998. The Communist Manifesto. London: Verso.

Matta, Roberto da. 1987. "The Quest for Citizenship in a Relational Universe." In State and Society in Brazil, ed. John Wirth, Edson de Oliveira Nunes, and Thomas Bogenschild, 307-35. Boulder, CO: Westview Press.

Maya, Adriana, ed. 1998. Geografía Humana de Colombia. Tomo VI. Los afrocolombianos. Bogota: Instituto Colombiano de Cultura Hispánica.

Means, Robert. 1973. "Codification in Latin America." Texas Law Review 52, no. 1: $18-42$.

Medina, Carlos A. 2002. "Oferta laboral en Colombia de acuerdo al color de la piel." Documento Cede. Bogota, Colombia: Universidad de los Andes.

Mehta, Uday Singh. 1999. Liberalism and Empire. Chicago: University of Chicago Press.

Mignolo, Walter. 2008. "The Geopolitics of Knowledge and the Colonial Difference." In Coloniality at Large, ed. Mabel Moraña, Enrique Dussel, and Carlos A. Jáuregui, 225-58. Durham, NC: Duke University Press. 
Miliband, Ralph. 1969. The State in Capitalist Society. New York: Merlin Press.

Millar, Fergus. 1998. The Crowd in Rome in the Late Republic. Ann Arbor: University of Michigan Press.

Miller, M. Grace. 2004. The Rise and Fall of the Cosmic Race. The Cult of Mestizaje in Latin America. University of Texas Press.

Millot, Lorraine. 2005. "Hélène Carrère d'Encausse dérape à la télévision." Libération, November 15.

Ministerio del Interior de Colombia. 1998. Las comunidades negras. Nuevos espacios para la democracia participativa. Bogota: Presidencia de la República.

Minority Rights Group International. 1995. No Longer Invisible: Afro-Latin Americans Today. London: Minority Rights Group International.

Mockus, Antanus. 2009. "Policy Innovation and the Culture of Citizenship: Tapping the Moral Resources of a Metropolitan Population." Hertie School of Governance Working Papers, no. 38 (February 2009): 125-67. Available at www.hertie-school.org/binaries/addon/1056_publicspaces.pdf.

Morańa, Mabel, Enrique Dussel, and Carlos A. Jáuregui, eds. 2008. Coloniality at Large. Durham, NC: Duke University Press.

Moreno, Francisco Jose. 1969. Legitimacy and Stability in Latin America. New York: New York University Press.

Morley, David, and Kuan-Hsing Chen, eds. 1997. Stuart Hall. New York: Routledge. Mosquera, Juan de Dios. 2000. Racismo y Discriminación Racial en Colombia. Bogota: Publicación institucional del Movimiento Nacional Cimarrón.

Motterlini, Matteo, ed. 1999. For and Against Method. Chicago: University of Chicago Press.

Mouritsen, Henrik. 2001. Plebs and Politics in the Late Roman Republic. Cambridge: Cambridge University Press.

Moynihan, Daniel P., and C. S. Schelling, eds. 1969. On Understanding Poverty; Perspectives from the Social Sciences. New York: Basic Books.

Muñera, Alfonso. 2008. El Fracaso de la Nacion. Bogota, Colombia: Planeta.

Musgrave, Alan. 1993. Common Sense, Science, and Scepticism. New York: Cambridge University Press.

Ndiaye, Pap. 2008. La condition noire. Paris: Gallimard.

Nef, Jorge, and Bernd Reiter. 2009. The Democratic Challenge: Democratization and De-Democratization in Global Perspective. New York: Palgrave MacMillan.

Neves, Marcelo. 1994. "Entre subintegracao e sobreintegracao: A cidadania inexistente." DADOS (Rio de Janeiro) 37, no. 2: 253-76.

- June 2001. "From the Autopoesis to the Allopoesis of Law." Journal of Law and Society 28, no. 2: 242-64.

Ober, Josiah. 1989. Mass and Elite in Democratic Athens. Princeton, NJ: Princeton University Press. 
Ober, Josiah, and Charles Hendrick, eds. 1996. Demokratia. Princeton, NJ: Princeton University Press.

Oberti, Marco. 2008. "The French Republican Model of Integration: The Theory of Cohesion and the Practice of Exclusion.” New Directions for Youth Development 119 (Fall 2008): 55-74.

Observatory on Racial Discrimination. 2008. Racial Discrimination and Human Rights in Colombia. A Report on the Situation of the Rights of Afro-Colombians. Bogota, Colombia: Ediciones Uniandes.

O’Donnell, Guillermo, Jorge Vargas Cullell, and Osvaldo Iazzetta, eds. 2004. The Quality of Democracy. Notre Dame, IN: University of Notre Dame Press.

Oslender, Ulrich. 2002. "The Logic of the River: A Spatial Approach to EthnicTerritorial Mobilization in the Colombian Pacific Region.” Journal of Latin American Anthropology 7, no.2: 86-117.

- 2004. "Fleshing Out the Geographies of Social Movements: Colombia's Pacific Coast Black Communities and the 'Aquatic Space.' " Political Geography 23 (2004): 957-85.

Ostwald, Martin. 1986. From Popular Sovereignty to the Sovereignty of Law: Law, Society, and Politics in Fifth-Century Athens. Berkeley: University of California Press.

- 1996. "Shares and Rights: 'Citizenship' Greek Style and American Style." In Demokratia, ed. Josiah Ober and Charles Hendrick, 49-61. Princeton, NJ: Princeton University Press.

Pardo, Mauricio. 2000. Acción colectiva, Estado y etnicidad en el Pacífico colombiano. Bogota, Colombia: Instituto Colombiano de Antropologíae Historia.

—. 2002. "Entre la autonomía y la institucionalización: Dilemas del movimiento negro colombiano." Journal of Latin American Anthropology 7, no. 2: 60-85.

Paschel, Tianna S. 2010. “The Right to Difference: Explaining Colombia's Shift from Color-Blindness to the Law of Black Communities." American Journal of Sociology 116, no. 3: 729-69.

Paschel, Tianna, and Mark Q. Sawyer. 2008. "Contesting Politics as Usual: Black Social Movements, Globalization, and Race Policy." SOULS Interdisciplinary Journal of Black Politics, Society and Culture 10, no. 3: 197-214.

Peabody, Sue. 2002. There Are No Slaves in France. New York: Oxford University Press.

Pearce, Jenny. 1990. Colombia: Inside the Labyrinth. London: Latin American Bureau.

Pinheiro, Teresa. 2008. "Emigration, Immigration and Interculturality: The Meaning of the European Year of Intercultural Dialogue in Portugal.” Eurolimes: Journal of the Institute for Euroregional Studies (Jean Monnet European Centre of Excellence, University of Oradea and University of Debrecen) 6: 63-73. 
Pires, Rui Pena. 2003. Migracoes e integracao: Teoria e aplicacoes a sociedade portuguesa. Oeiras: Celta.

Plutarch. 1960. The Rise and Fall of Athens: Nine Greek Lives. New York: Penguin Classics.

Pocock, J. G. A. 1973. "Verbalizing a Political Act: Towards a Politics of Speech." Political Theory 1, no.1 (February 1973): 27-45.

- 1975. The Machiavellian Moment. Princeton, NJ: Princeton University Press.

- 1981. "Virtues, Rights, and Manners: A Model for Historians of Political Thought.” Political Theory 9, no. 3 (August 1981): 353-68.

- 1995. "The Ideal of Citizenship since Classical Times." In Theorizing Citizenship, Ronald Beiner, 29-52. Albany, NY: SUNY Press.

Polonsky, Antony. 2009. The Jews in Poland-Lithuania and Russia, 1350 to the Present Day. Vol. 1, 1350-1881. Oxford: Littman Library of Jewish Civilization.

Popper, Karl. 1974. Objective Knowledge: An Evolutionary Approach. New York: Oxford University Press.

- 2002. The Logic of Scientific Inquiry. London: Routledge.

Portes, Alejandro, and Ruben Rumbaut. 2001. Legacies: The Story of the Immigrant Second Generation. New York: Sage Publications.

Portes, Alejandro, and Min Zhou. 1993. "The New Second Generation: Segmented Assimilation and Its Variants.” Annals AAPSS 530 (November 1993): 74-98.

Portilla, Dario A. 2003. "Mercado Laboral y Discriminacion Racial. Una Aproximación para Cali.” Documento CEDE. Bogota, Colombia: Universidad de los Andes.

Poulantzas, Nicos. 1968. State, Power, Socialism. New York: Verso.

Putnam, Robert. 1993. Making Democracy Work. Princeton, NJ: Princeton University Press.

Quijano, Anibal. 2008. "Coloniality of Power, Eurocentrism, and Social Classification.” In Coloniality at Large, ed. Mabel Moraña, Enrique Dussel, and Carlos A. Jáuregui, 181-224. Durham, NC: Duke University Press.

Ragin, Charles. 2008. Redesigning Social Inquiry: Fuzzy Sets and Beyond. Chicago: University of Chicago Press.

Rancière, Jacques. 2004. Disagreement: Politics and Philosophy. Minneapolis: University of Minnesota Press.

- 2007. On the Shores of Politics. New York: Verso.

Rawls, John. 1999. A Theory of Justice. Cambridge, MA: Belknap Harvard Press.

Reales, Leonardo. 2001. Prensa, Abolición y Racismo hacia los Afrocolombianos, 1810-1851. (Tesis de Pregrado en Historia). Bogota, Colombia: Universidad de los Andes. 
Análisis de Problemas Politicos, Económicos e Internacionales Contemporáneos). Bogota: Universidad Externado de Colombia / IAED.

Reis, Elisa. 1990. "Oppressão burocratica: O ponto de vista do cidadáo." Estudos Historicos (Rio de Janeiro) 3, no. 6 (1990): 161-79.

Reiter, Bernd. 2006. "The Hermeneutic Foundations of Qualitative Research." Qualitative Methods (Fall 2006): 18-24.

- 2008. "The Perils of Empire: Nationhood and Citizenship in Portugal." Citizenship Studies 12, no. 4 (August 2008): 397-412.

- 2009. Negotiating Democracy in Brazil. Boulder, CO: New Forum Press. - 2010. "Whiteness as Capital: Constructing Inclusion and Defending Privilege." In Brazil's New Racial Politics, eds. Bernd Reiter and Gladys Mitchell, 19-34. Boulder, CO: Lynne Rienner Publishers.

— 2012. "Framing Non-Whites and Producing Second-Class Citizens in France and Portugal." Journal of Ethnic and Migration Studies 38, no. 7: 1067-84.

Reiter, Bernd, and Kimberly Eison Simmons, eds. 2012. Afro-Descendants, Identity, and the Struggle for Development in the Americas. East Lansing: Michigan State University Press.

Restrepo, Eduardo. 2004. "Ethnicization of Blackness in Colombia: Toward De-Racializing Theoretical and Political Imagination." Cultural Studies 18: 698-715.

Rhodes, Peter J., ed. 2004. Athenian Democracy. New York: Oxford University Press. Rihil, T. E. 1995. "Democracy Denied: Why Ephialtes Attacked the Areopagus." Journal of Hellenic Studies 115 (1995): 87-98.

Rodríguez, Encarnación Gutiérrez, Manuela Boatcă, and Sérgio Costa, eds. 2010. Decolonizing European Sociology. Farnham, UK: Ashgate.

Rodríguez Garavito, César, Tatiana Alfonso Sierra, and Isabel Cavelier Adarve. 2008. The Right Not to Be Discriminated Against: The First Report on Racial Discrimination and the Rights of the Afro-Colombian Population. Bogota, Colombia: Universidad Los Andes.

Roediger, David. 1999. The Wages of Whiteness. London: Verso.

Roldán, Roque, and Enrique Sánchez. 2002. Titulación de los territorios comunales afrocolombianos e indígenas en la Costa Pacífica de Colombia. Washington, DC: Banco Mundial, Ministerio del Medio Ambiente de Colombia.

Romero, Mario. 1998. "Familia afrocolombiana y construcción territorial en el Pacífico Sur." Geografia Humana de Colombia. Tomo VI. Los afrocolombianos, ed. Adriana Maya, Bogota: Instituto Colombiano de Cultura Hispánica.

Rosanvallon, Pierre. 1992. Le sacre du citoyen. Paris: Gallimard.

Rosello, Mireille. 2001. Postcolonial Hospitality: The Immigrant as Guest. Stanford, CA: Stanford University Press. 
Rousseau, Jean Jaques. 1762. The Social Contract. http://www.constitution.org/jjr/ socon.htm.

Ruggie, John Gerard. 1998. Constructing the World Polity. New York: Routledge.

Sabatier, Colette. 2007. "Ethnic and National Identity among Second-Generation Immigrant Adolescents in France: The Role of Social Context and Family." Journal of Adolescence 31: 185-205.

Sandel, Michael. 1998. Democracy's Discontent. New York: Belknap.

Sánchez, Enrique, Roque Roldán, and María Fernanda Sánchez. 1993. Los pueblos indigenas y negros en la Constitución Politica de Colombia de 1991. Bogota, Colombia: Disloque editores.

Sanchez, Margarita, and Maurice Bryan. 2003. Afro-descendants, Discrimination and Economic Exclusion in Latin America. London: MRGI.

Sarlemijn, Andries. 1971. Hegelsche Dialektik. Berlin: Walter de Gruyter Verlag.

Sartre, Jean-Paul. 1994. Being and Nothingness. New York: Gramercy.

Sayer, Andrew. 2010. Method in Social Science. London: Routledge.

Schiller, Bradley R. 1970. "Stratified Opportunities: The Essence of the 'Vicious Circle.'" American Journal of Sociology 76, no. 3: 426-442.

Scullard, H. H. 1982. From the Gracchi to Nero: A History of Rome from 133 bc to ad 68. London: Routledge.

Sealey, Raphael. 1964. "Ephialtes.” Classical Philology 59, no. 1 (January 1964): 11-22.

Searle, John. 1997. The Construction of Social Reality. New York: Free Press.

Sen, Amartya. 1992. Inequality Reexamined. Cambridge, MA: Harvard University Press.

— 2000. Freedom as Development. Cambridge, MA: Harvard University Press.

Shachar, Ayelet. 2009. The Birthright Lottery: Citizenship and Global Inequality. Cambridge, MA: Harvard University Press.

Sharp, William. 1968. "El Negro en Colombia. Manumisión y Posición Social." Razón y Fábula 8: 91-107.

Shlapentokh, Dmitry. 2008. Societal Breakdown and the Rise of the Early Modern State in Europe. New York: Palgrave Macmillan.

Shotter, David. 1994. The Fall of the Roman Republic. London: Routledge.

Silberman, Roxane, Ricard Alba, and Irene Fournier. 2007. "Segmented Assimilation in France? Discrimination in the Labour Market against the Second Generation." Ethnic and Racial Studies 30, no. 1 (January 2007): 1-27.

Simon, Patrick. 2003. "France and the Unknown Second Generation: Preliminary Results on Social Mobility." IMR 37, no. 4 (Winter 2003): 1091-19.

Skidmore, Thomas E. 1993. Black into White: Race and Nationality in Brazilian Thought. Durham, NC: Duke University Press. 
Smail, Daniel Lord. 2001. "Hatred as a Social Institution in Late-Medieval Society." Speculum 76, no. 1 (January 2001): 90-126.

Smith, Amir. 1986. Visión Socio Cultural del Negro en Colombia. Bogota, Colombia: Centro de Investigaciones de la Cultura Negra en Colombia / Editorial PRAG.

Somers, Margaret. 1993. "Citizenship and the Place of the Public Sphere: Law, Community, and Political Culture in the Transition to Democracy." American Sociological Review 58, no. 5 (October): 587-620.

- 2008. Genealogies of Citizenship. New York: Cambridge University Press.

Sousa, Constanca Urbana de. 2002. "The New Portuguese Immigration Act.” European Journal of Migration and Law 4: 49-69.

Souza, Jesse. 2001. "A sociologia dual de Roberto da Matta: Descobrindo nossos misterios ou sistematizando nossos auto-enganos?" Revista Brasileira de Ciencias Sociais 16, no. 45 (February 2001): 47-67.

Soysal, Jasmin. 1994. The Limits of Citizenship. Chicago: University of Chicago Press.

Srivastava, Prachi, and Nick Hopwood. 2009. "A Practical Iterative Framework for Qualitative Data Analysis.” International Journal of Qualitative Methods 8, no. 1 (2009).

Stepan, Nancy Leys. 1986. "Race and Gender: The Role of Analogy in Science." Isis 77, no. 2: 261-77.

- 1991. The Hour of Eugenics. Ithaca, NY: Cornell University Press.

Stockton, David. 1979. The Gracchi. New York: Oxford University Press.

Stoler, Ann. 2002. Carnal Knowledge and Imperial Power: Race and the Intimate in Colonial Rule. Berkeley: University of California Press.

Stovall, Tyler, and Georges van den Abbeele, eds. 2003. French Civilization and Its Discontents. Lanham, MD: Lexington Books.

Syme, Ronald. 1956. The Roman Revolution. New York: Oxford University Press.

Tajfel, Henri. 2010. Social Identity and Intergroup Relations. London: Cambridge University Press.

Tarrow, Sidney. 1994. Power in Movement. New York: Oxford University Press.

Teller, Adam, Magda Teter, and Antony Polonsky, eds. 2010. Polin: Social and Cultural Boundaries in Pre-Modern Poland. Vol. 22. Oxford: Littman Library of Jewish Civilization.

Telles, Edward. 2004. Race in Another America: The Significance of Skin Color in Brazil. Princeton, NJ: Princeton University Press.

Telles, Edward, and René Flores. 2012. "Not Just Color: Whiteness, Nation, and Status in Latin America." Hispanic American Historical Review, forthcoming.

Thompson, Elisabeth. 2000. Colonial Citizens. New York: Columbia University Press.

Thorley, John. 1996. Athenian Democracy. London and New York: Routledge. 
Tin, Louis-Georges. 2008. "Who Is Afraid of Blacks in France?" French Politics, Culture \& Society 26, no. 1 (Spring 2008): 32-44.

Tocqueville, Alexis de. 1955. The Old Regime and the French Revolution. New York: Doubleday.

- 2003. Democracy in America. New York: Penguin Classics.

Tulchin, Joseph, and Meg Ruthenberg. 2007. Citizenship in Latin America. Boulder, CO: Lynne Rienner Publishers.

Ulyssea, Gabriel, and Dimitri Szerman. 2006. Job Duration and the Informal Sector in Brazil. Rio de Janeiro: IPEA.

United Nations Educational, Scientific and Cultural Organization. 2005. The Cultural Space of Palenque de San Basilio. Paris: UNESCO.

United Nations Human Rights Committee. 1994. General Comment on the Rights of Minorities. New York: United Nations.

United Nations Mission to Colombia. 2002. Compilación de Instrumentos Internacionales. Bogota, Colombia: United Nations.

2006. La Población Afrodescendiente en Colombia. Los Pueblos Indígenas y Afrodescendientes en América Latina y el Caribe. Santiago, Chile: CEPAL.

Urrea, Fernando, and Carlos A. Viáfara. 2006. "Efectos de la Raza y el Género en Logro Educativo y Status Socio-Ocupacional para Tres Ciudades de Colombianas." Revista Desarrollo y Sociedad:115-63.

Urrea, Fernando, Carlos A. Viáfara, H. F. Ramírez, E. Gómez, S. Vélez, and F. Ruiz. 2005. Pobreza y Grupos Étnicos en Colombia: Análisis de sus Factores Determinantes y Lineamientos de Politica para su Reducción. Informe final presentado al Departamento Nacional de Planeación, DNP.

Utria, Rubén. 1999. "Una reflexión y una propuesta sobre la paz en Colombia." In La Guerra y la Paz en la segunda mitad del siglo XX en Colombia, ed. Raúl Alameda. Bogota, Colombia: Editorial Controversia.

Vala, Jorge, Dinoz Lopes, and Marcus Lima. 2008. "Black Immigrants in Portugal: Luso-Tropicalism and Prejudice.” Journal of Social Issues 64, no. 2: 287-302.

Valente Rosa, Maria Joao. 2005. “(Des)encontro entre as migracoes internacionais (laborais) e as qualificacoes (escolares): O caso dos euroipeus de Leste em Portugal.” SOCINOVA Working Paper. Available at http://socinovamigration.org/ conteudos.asp? IDCONT=305.

Vanderbroeck, Paul. 1987. Popular Leadership and Collective Behavior in the Late Roman Republic (ca. 80-50 b.c.). Amsterdam: J.C. Gieben.

Vital, David. 1999. A People Apart: The Jews in Europe, 1789-1939. New York: Oxford University Press.

Wacquant, Loic. 2008. Urban Outcasts. Cambridge: Polity.

Wade, Peter. 2001. "Racial Identity and Nationalism: Theoretical View from Latin America." Ethnic and Racial Studies 24, no. 5: 845-65. 
2005. "Rethinking Mestizaje: Ideology and Lived Experience." Journal of Latin American Studies 37: 239-57.

Waley, Daniel, and Trevor Dean. 2010. The Italian City-Republics. Harlow, UK: Pearson Education Ltd.

Wallace, Robert A. 1996. "Law, Freedom, and the Concept of Citizen Rights in Ancient Athens." In Demokratia, ed. Josiah Ober and Charles Hendrick, 10519. Princeton, NJ: Princeton University Press.

Walters, Kenneth. 1983. "Perikles' Citizenship Law." Classical Antiquity 2, no. 2 (October 1983): 314-36.

Walzer, Michael. 1983. Spheres of Justice. New York: Basic Books.

Weber, Max. 1968. Economy and Society. New York: Bedminster Press.

Weil, Patrick. 2008. How to Be French. Durham, NC: Duke University Press.

Wendt, Alexander. 1999. Social Theory of International Politics. New York: Cambridge University Press.

Whorf, Benjamin Lee, and John B. Carroll. 1964. Language, Thought, and Reality. Cambridge, MA: MIT Press.

Wilder, Gary. 2004. "Race, Reason, Impasse: Césaire, Fanon, and the Legacy of Emancipation." Radical Historical Review 90 (Fall 2004): 31-61.

- 2005. The French Imperial Nation State: Negritude and Colonial Humanism between the Two World Wars. Chicago: University of Chicago Press.

Winant, Howard. 2001. The World Is a Ghetto. New York: Basic Books.

Winch, Peter. 2008. The Idea of a Social Science and Its Relation to Philosophy. London: Routledge.

Wittgenstein, Ludwig. 2009. PhilosophicalInvestigations. New York: Wiley-Blackwell. Wolin, Sheldon. 1996. "Transgression, Equality, and Voice." In Demokratia, ed. Josiah Ober and Charles Hendrick, 63-90. Princeton, NJ: Princeton University Press.

Wolkmer, Antonio Carlos. 2003. Historia do Direito no Brasil. Rio de Janeiro: Forense.

Wouters, Mieke. 2001. "Ethnic Rights Under Threat: The Black Peasant Movement Against Armed Groups' Pressure in the Choco, Colombia." Bulletin of Latin American Research 20, no. 4: 498-519.

Yashar, Deborah. 2005. Contesting Citizenship in Latin America: The Rise of Indigenous Movements and the Postliberal Challenge. New York: Cambridge University Press.

Young, Iris Marion. 1990. Justice and the Politics of Difference. Princeton, NJ: Princeton University Press.

Zakaria, Fareed. 2003. The Future of Freedom. New York: W.W. Norton \& Company.

Zappi, Sylvie. 2004. "Les jeunes diplômés issus de l'immigration ont des difficultés à trouver un emploi." Le Monde, April 24, 2004.

Zoninsein, Jonas. 2001. The Economic Case for Combating Racial and Ethnic Exclusion in Latin America. Washington, DC: Inter-American Development Bank. 


\section{Index}


